UNIVERSIDADE DE SÃO PAULO

ESCOLA DE COMUNICAÇÃO E ARTES

PROGRAMA DE PÓS-GRADUAÇÃO EM ARTES CÊNICAS

\title{
O QUE É PÚBLICO NÃO É DE VOCÊS \\ A ATBC E OS MODELOS DE GESTÃO DOS GRUPOS DE TEATRO EM SÃO PAULO
}

Stênio Dias Ramos

SÃo PAULO

2019

UNIVERSIDADE DE SÃO PAULO

ESCOLA DE COMUNICAÇÃO E ARTES

PROGRAMA DE PÓS-GRADUAÇÃO EM ARTES CÊNICAS 


\title{
O QUE É PÚBLICO NÃO É DE VOCÊS:
}

\section{A ATBC E OS MODELOS DE GESTÃO DOS GRUPOS DE TEATRO EM SÃO PAULO}

Versão corrigida (Versão Original disponível na Biblioteca da ECA/USP)

\begin{abstract}
Dissertação apresentada ao Programa de Pós-Graduação em Artes Cênicas da Universidade de São Paulo, como requisito final para obtenção do título de Mestre em Artes Cênicas, Área de concentração: Teoria e Prática do Teatro Linha de Pesquisa: História do Teatro Orientador: Prof. Dr. Ferdinando Crepalde Martins
\end{abstract}


Autorizo a reprodução e divulgação total ou parcial deste trabalho, por qualquer meio convencional ou eletrônico, para fins de estudo e pesquisa, desde que citada a fonte. 


\section{RESUMO}

Esta dissertação trata da formação e consolidação de modelos de gestão de grupos e companhias teatrais da $1^{\text {a }}$ metade do século XX até o fim da década de 1960 com base em suas relações com entes públicos e privados desde a transição entre os grupos semiprofissionais, amadores e estudantis, passando pelas companhias que mantiveram sedes próprias - como o TBC - e que originaram outras a partir de artistas proeminentes saídos de suas bases - como as de Cacilda Becker, Nydia Lícia-Sergio Cardoso e de Tônia-Celi-Autran - trazendo seus desdobramentos até o momento atual, onde tais relações e seus possíveis alcances parecem ainda pouco estabelecidos, com ações teatrais sendo concretizadas através de uma dependência a leis e políticas tênues que podem ser interrompidas a qualquer momento.

O objetivo deste trabalho é colocar as relações do teatro com o poder público em uma perspectiva histórica a partir do chamado "modelo TBC", que reconhecidamente suscitou uma nova perspectiva à profissionalização dos grupos de teatro no país ao fazer com que aqueles que saíram dessa companhia teatral pudessem replicar muitas de suas ações benéficas ao teatro - como investir na formação técnica dos atores, trazer novas ideias e pessoas influentes de alta excelência em suas funções no exterior para trabalhar com os profissionais locais - assim como alguns de seus vícios - como o financiamento público baseado principalmente em relações com o poder público ou nas leis de incentivo; o descaso quanto à captação de recursos complementares em outras fontes; o interesse predatório de entes privados sobre o fazer artístico e a cidade; e certa perda de sintonia com os desejos do público espectador e as demandas da classe teatral.

Pretende-se assim explicitar o quanto esses mecanismos continuam se perpetuando pelos dias de hoje, fazendo com que o projeto de reabertura do TBC levado pela ATBC (Associação dos Amigos do TBC e do Teatro Brasileiro) possa se tornar uma nova possibilidade de se trabalhar artisticamente a partir de uma perspectiva de sustentabilidade diversa da que segue em voga. Para isso, este trabalho se referenciará a notícias de jornal do período em que o TBC manteve sua companhia ativa (1948-1964), além de trechos dos livros de Silveira (1976), Arruda (2001/2005), Pontes (2011), Lícia (2007). Guzik (1986), Barros de Almeida (1987), entre outros, além de histórias e relatos reunidos na revista Dionysos (1980) sobre o TBC.

PALAVRAS-CHAVE História do Teatro Brasileiro; Gestão; Teatro de Grupo 


\begin{abstract}
This dissertation deals with the formation and consolidation of management models for theater groups and companies from the first half of the 20th century until the end of the 1960s based on their relationships with public and private entities since the transition between semiprofessional, amateur and student groups, to companies that have their own headquarters - such as $\mathrm{TBC}$ and other ones oiginated from prominent artists who left TBC, such as Cacilda Becker, Nydia Lícia-Sergio Cardoso and TôniaCeli-Autran - bringing its developments until present times, where such relations and possible scope seem still poorly established, with theatrical actions being realized through a dependence on weak laws and policies that can be interrupted at any moment.
\end{abstract}

The aim of this work is to put the relations of the theater with the public power in a historical perspective from the so-called "TBC model", which admittedly gave rise to a new perspective to the professionalization of theater groups in the country by making those who left this theater company replicate many of its positive actions toward theater - like investing on technical training for actors, bringing new ideas and influences of high excellence from abroad to work with local professionals - as well as some of its vices - such as public funding based primarily on relations with the public power, or on incentive laws; disregard for the collection of complementary funding from other sources; the predatory interest of the private sector over the artistic work and the city; and a certain loss of attunement to the desires of the spectators and the demands of the theater class.

The objective is to explain how these mechanisms continue to be perpetuated today, making the project to reopen TBC held by ATBC (Association of Friends of $\mathrm{TBC}$ and Brazilian Theater) become a new possibility for a sustainable work from a different perspective to the one in trend nowadays. To that end, this work will refer to newspaper reports from the period in which TBC maintained its company on action (1948-1964), as well as excerpts from the books by Silveira (1976), Arruda (2001/2005), Pontes (2011), Lícia (2007). Guzik (1986), Barros de Almeida (1987), among others, with stories and narrations gathered in the magazine Dionysos (1980) about TBC.

KEYWORDS Brazilian Theater History; Management; Group Theater 


\section{AGRADECIMENTOS}

À minha família, Maria, Clóvis, Fabio, Ariane, que compreenderam os sacrifícios para que eu pudesse chegar até aqui.

À ajuda espiritual e afetuosa que tive de tantos amigos e companheiros que seguem no meu caminho, aqui e em outras partes.

Aos professores da USP que me seguiram nessa trajetória, em especial: Ferdinando Martins, meu orientador, por todo o suporte e direcionamento essenciais para o trabalho de um bom pesquisador; Beth Azevedo, por todo o trabalho que vem fazendo no LIMCAC - Laboratório de Informação e Memória das Artes Cênicas; e Maria Sílvia Betti, por sua defesa e conhecimento na contínua interlocução do teatro brasileiro com o estrangeiro.

Aos integrantes da ATBC, Álvaro Machado, Guilherme Marques, Ruy Cortez, João Carlos Couto, Américo Córdula, Silvio Restiffe, e seus associados honorários como Sergio Mamberti e Denise Fraga, pelo convite para participar desde seu início desta luta pela memória e abertura do TBC e por todo o incentivo que me deram para prosseguir brigando contra os moinhos de vento de nossa política cultural.

À Célia Gouvêa Vaneau, pelo acesso voluntarioso e desimpedido ao Acervo GouvêaVaneau, em que guarda com tanto carinho e dedicaçãoo legado de seu marido e companheiro de vida. Que ele possa seguir encontrando eco na sociedade.

À Biblioteca Nacional, pelo seu trabalho em disponibilizar a Hemeroteca Digital para todas as pessoas que querem acessar seu rico acervo. É preciso sempre valorizar as iniciativas de preservação da memória para que se saiba de onde partimos e para onde vamos enquanto nação. 
ÍNDICE DE SIGLAS

\begin{tabular}{|c|c|}
\hline Sigla & Descrição \\
\hline AI-5 & ATO INSTITUCIONAL N.5 \\
\hline APCA & Associação Paulista de Críticos de Arte (ABCT/APCT, até 1972) \\
\hline АТВC & Associação dos Amigos do Teatro Brasileiro de Comédia e do Teatro Brasileiro \\
\hline BANESPA & Banco do Estado de São Paulo \\
\hline BNDES & Banco Nacional de Desenvolvimento Econômico e Social \\
\hline CCC & Comando de Caça aos Comunistas \\
\hline CDB & Conservatório Dramático Brasileiro \\
\hline CDN & Companhia Dramática Nacional \\
\hline CET & Comissão Estadual de Teatro \\
\hline CEU & Centro Educacional Unificado \\
\hline CLT & Consolidação de Leis do Trabalho \\
\hline CMTC & Companhia Municipal de Transportes Coletivos \\
\hline CONPRESP & $\begin{array}{l}\text { Conselho Municipal de Preservação do Patrimônio Histórico, Cultural e Ambiental da } \\
\text { Cidade de São Paulo }\end{array}$ \\
\hline CONDEPHAAT & $\begin{array}{l}\text { Conselho Estadual de Defesa do Patrimônio Histórico, Arquitetônico, Artístico e } \\
\text { Turístico do Estado de São Paulo }\end{array}$ \\
\hline CPT & Cooperativa Paulista de Teatro \\
\hline DCDP & Divisão de Censura de Diversões Públicas (do Rio de Janeiro e São Paulo) \\
\hline DFSP & Departamento Federal de Segurança Pública \\
\hline DIP & Departamento de Imprensa e Propaganda \\
\hline DRT & Delegacia Regional do Trabalho (órgão responsável pelo registro atoral) \\
\hline EAD & Escola de Arte Dramática \\
\hline FAU & Faculdade de Arquitetura e Urbanismo da USP \\
\hline FECOMERCIO & Federação do Comércio de Bens, Serviços e Turismo do Estado de São Paulo \\
\hline FNC & Fundo Nacional de Cultura \\
\hline FUNARTE & Fundação Nacional de Artes \\
\hline FUNDACEN & Fundação Nacional das Artes Cênicas (INACEN, até 1987) \\
\hline GTE & Grupo de Teatro Experimental \\
\hline GUT & Grupo Universitário de Teatro \\
\hline IAB & Instituto dos Arquitetos do Brasil \\
\hline IBGE & Instituto Brasileiro de Geografia e Estatística \\
\hline ICMS & $\begin{array}{l}\text { Imposto estadual sobre operações relativas à Circulação de Mercadorias e sobre } \\
\text { prestações de Serviços de transporte interestadual e intermunicipal e de comunicação }\end{array}$ \\
\hline IPHAN & Instituto do Patrimônio Histórico e Artístico Nacional (SPHAN, até 1937) \\
\hline IPTU & Imposto sobre a Propriedade Predial Urbana \\
\hline LAO & Liceu de Artes e Ofícios \\
\hline МАМ & Museu de Arte Moderna \\
\hline MASP & Museu de Arte de São Paulo \\
\hline MEI & Microempreendedor Individual \\
\hline MES & Ministério de Educação e Saúde (Pública, até 1937) \\
\hline MEC & Ministério da Educação (e Cultura, de 1953 até 1985) \\
\hline MTG & Movimento Teatro de Grupo \\
\hline MVPA & Maurice Vaneau Produções Artísticas \\
\hline NEA & National Endowment for the Arts \\
\hline OIT & Organização Internacional do Trabalho \\
\hline ONG & Organização não-governamental \\
\hline OS & Organização Social \\
\hline OSCIP & Organização da Sociedade Civil de Interesse Público \\
\hline PEC & Proposta de Emenda à Constituição \\
\hline PJ & Pessoa Jurídica \\
\hline PPP & Parceria Público-Privada \\
\hline S.A. & Sociedade Anônima \\
\hline SBAT & Sociedade Brasileira dos Autores Teatrais \\
\hline SBC & Sociedade Brasileira de Comédia \\
\hline SESC & Serviço Social do Comércio \\
\hline SESI & Serviço Social da Indústria \\
\hline SNT & Serviço Nacional do Teatro \\
\hline TAIB & Teatro de Arte Israelita Brasileiro \\
\hline ТВC & Teatro Brasileiro de Comédia \\
\hline TMDC & Teatro Maria Della Costa \\
\hline TNC & Teatro Nacional de Comédia \\
\hline TPE & Teatro Paulista do Estudante \\
\hline UPCT & Uniao Paulista da Classe Teatral \\
\hline USP & Universidade de São Paulo \\
\hline
\end{tabular}




\section{ÍNDICE DE IMAGENS}

Imagem 1 - Fachada do TBC em 2016

Imagem 2 - Localização do TBC na Bela Vista (sinalizada pela seta), com destaque para Teatro Oficina e Teatro Renault na mesma região ............................................20 Imagem 3 - Charge de Ângelo Agostini publicada na revista O Cabrião em 1867......29 Imagem 4 - Mapa da cidade de São Paulo em 1877 (com indicação por seta do Teatro

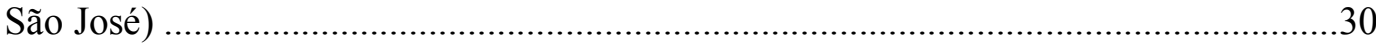

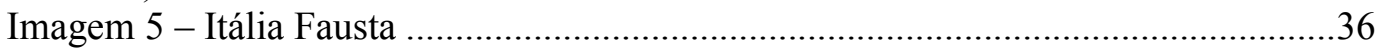
Imagem 6 - Alfredo Mesquita nas escadas do Teatro Municipal com o elenco de "A

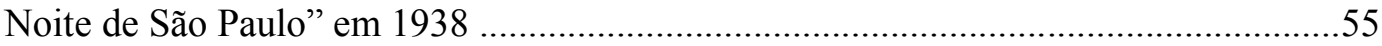
Imagem 7 - Passeata em favor dos teatros de São Paulo................................................63 Imagem 8 - Ciccillo Matarazzo e Franco Zampari...........................................................65 Imagem 9 - Apresentação da Sociedade Brasileira de Comédia em programa do GTE no Teatro Municipal em 1948.................................................................................. 79 Imagem 10 - Apresentação do TBC em programa do GTE no Municipal em 1948......85

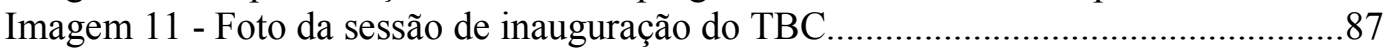
Imagem 12 - Borderô da sessão de inauguração do TBC...............................................8 Imagem 13 - Cenário da peça "A Noite de 16 de Janeiro" no TBC.................................95 Imagem 14 - Elenco de "A Noite de 16 de Janeiro"......................................................95 Imagem 15 - Sergio Cardoso, Nydia Lícia e Cacilda Becker em "Entre Quatro Paredes"

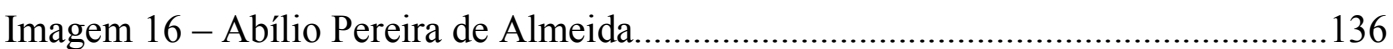

Imagem 17 - Incêndio na sede do TBC em São Paulo em 1954...................................141

Imagem 18 - Convite para estréia de "Casa de Chá do Luar de Agosto" .....................152 Imagem 19 - Fernanda Montenegro com Ziembinski; Maurice Vaneau com Cacilda

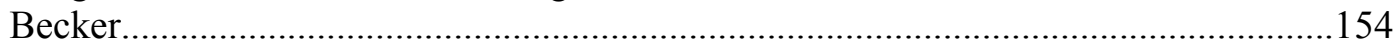

Imagem 20 - Processo na Câmara Municipal de São Paulo para auxílio ao TBC........169 Imagem 21 - Processo na Câmara dos Deputados para auxílio ao TBC em 1958........170 Imagem 22 - Flávio Rangel e Gianfrancesco Guarnieri ...........................................180 Imagem 23 - Capa do programa da peça "A Semente"..................................................183

Imagem 24 - Cartão de Natal dos artistas e funcionários do TBC em 1963..................197

Imagem 25 - Capa do programa de "Arena Canta Bahia" no TBC...............................210

Imagem 26 - Logo ATBC ...................................................................................222

Imagem 27 - Ato do Teatro Oficina em 25 de novembro de 2017............................227

Imagem 28 - Seminário TBC na Biblioteca Mário de Andrade em maio de 2018.......229 Imagem 29 - Reunião para tratativas com SESC e FECOMERCIO pela reabertura do

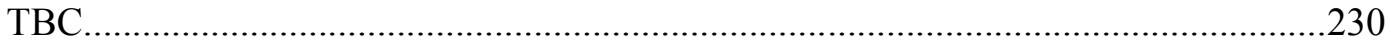

Imagem 30 - Marcha do Teatro Oficina pelo Parque do Bixiga..................................231

Imagem 31 - Mobilização do SATED na sede da FUNARTE em SP...........................244 
Sumário

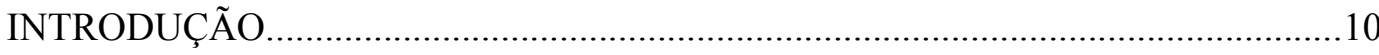

CAPÍTULO 1: Financiamento Público e Privado Pré-TBC ............................................21

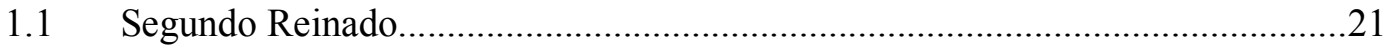

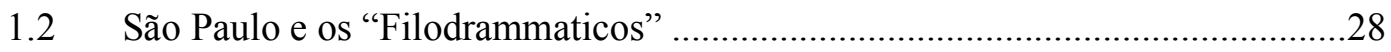

1.3 Estrutura Estatal Moderna e Influência dos Grupos Estudantis..........................40

CAPÍTULO2: O TBC e suas relações com o poder público: empréstimos, intervenções

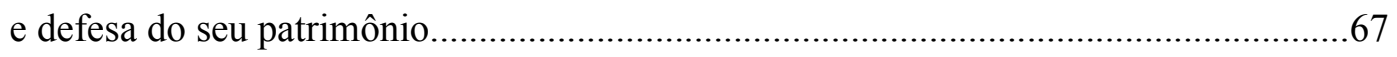

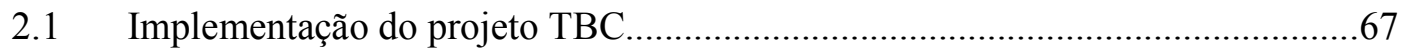

2.2 Marcos Iniciais do TBC, Sua Profissionalização e o Contato com a Máquina

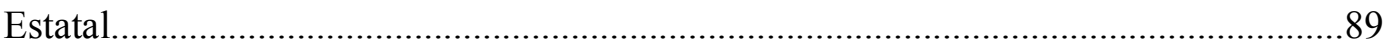

2.3 Consolidação do "modelo TBC" e as Políticas Públicas...................................109

2.4 Queda do TBC e os Auxílios e Intervenções Estatais........................................138

CAPÍTULO 3: A ATBC e a situação dos grupos de teatro independentes na cidade de

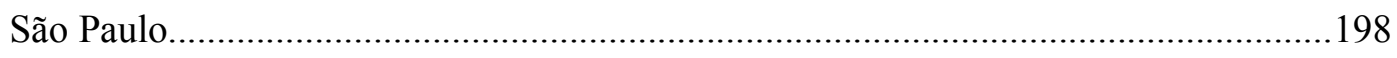

3.1 Evolução das Políticas para Grupos Teatrais Pós-1950_.....................................198

3.2 A Fase Final do TBC: Articulação do Teatro com Grupos e Coletivos Pós-1964 207

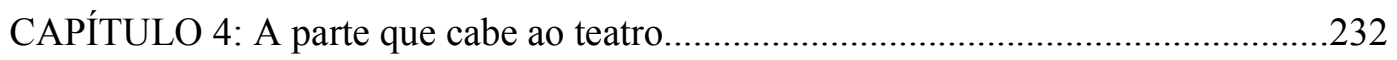

4.1 Outros Modos de Produção da Cena Teatral Paulistana....................................232

4.2 Políticas Públicas Nacionais e Sua Influência nos Modos de Produção.............255

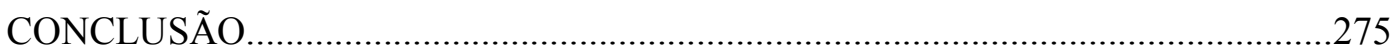

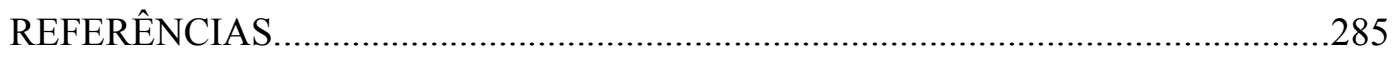

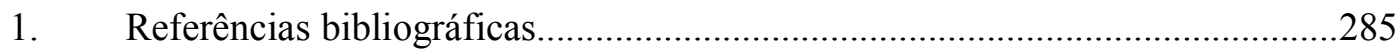




\section{INTRODUÇÃO}

Uma notícia chamou a atenção entre todas as que chegam até nós diariamente com fatos aparentemente corriqueiros, mas que contém em si uma quebra em suas ações rotineiras que fazem com que ganhem algum destaque nas pautas dos jornais impressos e eletrônicos. Tudo se deu a partir da reunião de um grupo de não mais que algumas dezenas de praticantes de ioga que resolveram já há quase dez anos se reunir em espaços ao ar livre de Curitiba, em um fim de semana por mês, em torno de um projeto comum com o nome simples e direto de Yoga no Parque.

Entretanto, em abril de 2018 esse grupo ganha um destaque inesperado quando guardas municipais e a administradora do Jardim Botânico, um dos cartões postais da cidade, interromperam a atividade do grupo que se reuiniria para a prática meditativa daquele domingo. Os líderes do grupo e todos os praticantes ficaram sem entender o que estava acontecendo de diferente para ter havido esta intervenção do mesmo poder público para o qual eles se voltaram para legalizar e institucionalizar essa prática, pelo fato de que eles alegavam ter havido contato prévio com órgãos da prefeitura da cidade autorizando essa reunião.

Entre as tentativas de argumentação de ambos os lados para fazerem valer suas vontades e aquilo que consideravam o mais justo a se fazer naquela situação, a então administradora do Jardim Botânico soltou uma frase que pode ser considerada emblemática não apenas daquele momento como de outras confusões as quais um cidadão comum se depara perante o poder público. Ela dizia repetidas vezes para os presentes que "aquele lugar era público; não era de vocês", como se fossem os praticantes de ioga que estivessem tomando o espaço apenas para si, e não aquela que considerava deter o poder para dizer o que eles podiam ou não fazer ali.

O resultado desse imbróglio é que o prefeito acabou intervindo diretamente para resolver a questão, pela autorização anterior ter sido dada por instâncias superiores à administração do parque. $\mathrm{O}$ grupo continua se reunindo regularmente todo mês em diversos locais da cidade, através dos mesmos trâmites usados até então. Um final feliz que parece uma exceção - principalmente por se tratar de uma atividade lúdica. 


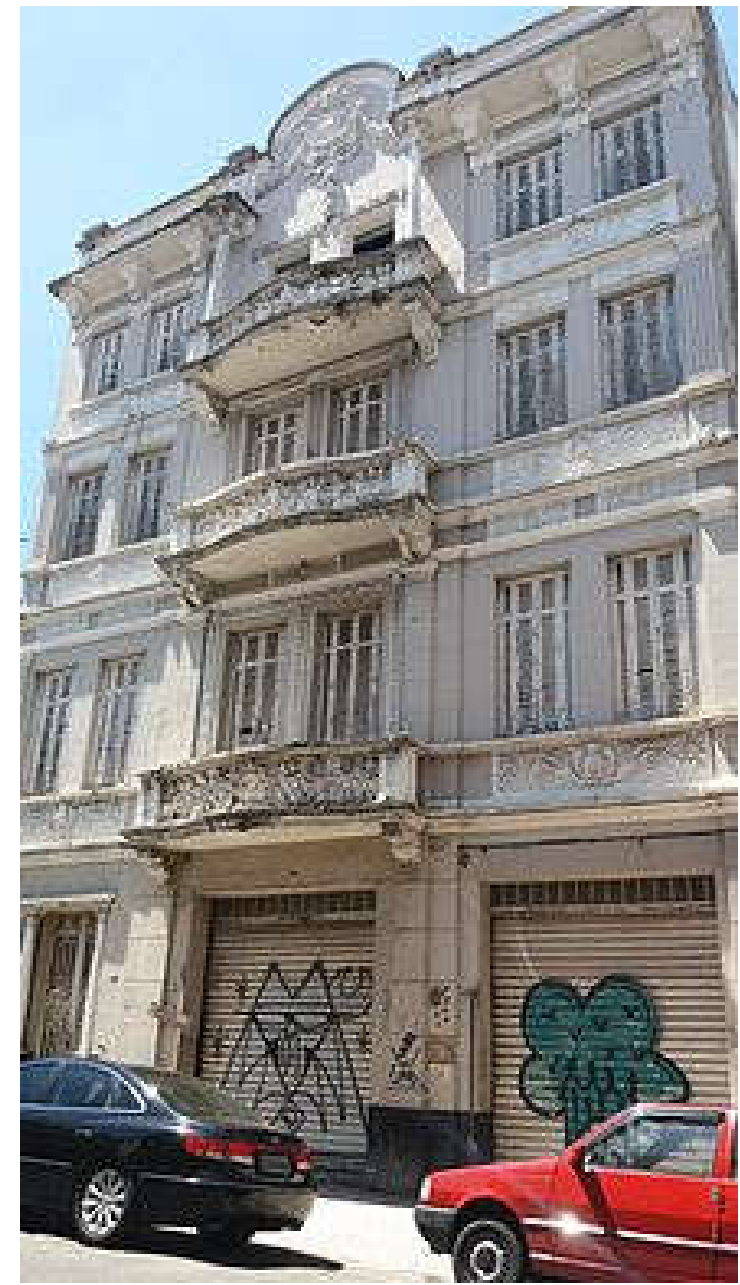

Imagem 1 - Fachada do TBC na Rua Major Diogo - São Paulo, em 2016.

Do mesmo modo, desde setembro de 2017 profissionais da área teatral têm trabalhado em conjunto com artistas no movimento "Salvar o TBC", tendo convocado desde então diversos encontros e petições assinadas por mais de quatro mil pessoas na plataforma Avaaz e nas redes sociais. A preocupação com o destino do prédio do TBC, fechado desde 2004 e comprado pela FUNARTE em 2007 com o intuito de reformá-lo e torná-lo o Memorial do Teatro Brasileiro, impulsionou a criação de um grupo que pretende ser uma nova versão da Sociedade Brasileira de Comédia (SBC) - fundada por Franco Zampari, Ciccillo Matarazzo e Paulo Assumpção em 1948 para juntar diferentes personalidades na busca de soluções para a implantação do teatro.

O movimento também chama a atenção para o fato de que o prédio é tombado por órgãos de preservação como o CONPRESP (Municipal) e CONDEPHAAT (Estadual) tendo nele sido investidos cerca de R\$20 milhões em sua reforma até o momento. Com a mudança da gestão do Ministério da Cultura em 2011, as obras de 
finalização e acabamento foram suspensas, e em 2017 seu ministro titular anunciou não ter condições para terminar a empreitada revelando o desejo de privatizar o teatro. Em abril de 2018, foi criada então oficialemente a Associação dos Amigos do Teatro Brasileiro de Comédia e do Teatro Brasileiro (ATBC), tendo entre seus fundadores artistas como Sergio Mamberti e Denise Fraga, além de apoiadores como Celso Frateschi, Nathalia Thimberg, Marcos Caruso e Fernanda Montenegro, diretores como Amir Haddad e dezenas de pesquisadores e produtores de teatro de várias partes do país.

A Sociedade Brasileira de Comédia serviu originalmente como modelo de aglutinação de diversos setores da sociedade para angariar fundos e preparar o projeto do prédio para implantação do TBC e sua companhia. A imprensa e a intelectualidade da época tiveram papéis muito importantes na consolidação deste teatro como um fato novo dentro da cultura paulistana e brasileira a partir de sua inauguração em outubro de 1948. Tanto as críticas de Décio de Almeida Prado em O Estado de S. Paulo, com suas impressões abalizadas sobre a dramaturgia e a técnica das obras apresentadas, como as reportagens de Mattos Pacheco no Diário da Noite sobre o cotidiano da companhia, assim como a revista Clima fundada por nomes como Antonio Cândido e Paulo Emilio Salles Gomes, faziam chegar a todos as leituras e exaltações dos feitos daquele momento único para o teatro paulistano e brasileiro.

A ATBC, buscando resgatar esse histórico de mobilização em prol de um legado cultural para a comunidade da Bela Vista, a cidade de São Paulo, e o país, mobilizou os artistas locais fazendo com que essa articulação alcançasse em primeiro lugar o Teatro Oficina. Este teatro hoje também tradicional na cidade tem uma relação muito próxima com o TBC não só fisicamente, mas também como local de inspiração estética. Ainda que por muito tempo sua atuação tenha parecido refratária ao que o TBC fazia, seus mentores como José Celso Martinez Correa valorizavam tudo que aquele teatro lhes trouxe de ensinamento e experiências. Como referência, lembra-se a série “Cacilda!" realizada pelo Oficina a partir de 1998, onde ao mesmo tempo que se falava da vida desta que foi a grande referência artística do TBC, tratava-se com reverência o espaço do teatro e toda a história teatral brasileira dos anos 1950 até o fim dos 1960.

O Teatro Oficina, no momento do início dessa mobilização em torno do TBC, empreendia uma fase aguda de sua campanha pública pela manutenção de seu projeto 
original a partir de demandas do Grupo Silvio Santos para construção de torres no terreno reivindicado para abrigar o Parque do Bixiga, projeto de valorização cultural da região que incluiria os teatros da região e imóveis históricos como a Casa de Dona Yayá (administrada hoje pela USP). Essa articulação foi consolidada em um grande ato público que reuniu em novembro de 2017 cerca de três mil pessoas contra a construção das torres, que teve em um de seus grandes momentos uma representação em frente ao TBC de Cacilda Becker "parindo" os grandes ícones do teatro brasileiro desde então.

Dessa maneira, o movimento ATBC vem articulando a criação do Território Cultural do Bixiga, que ampliaria o seu raio de ação para além do quadrilátero das companhias de teatro da região e dos prédios que ali ocupam. A partir da constatação de que outros teatros brasileiros passam pelo mesmo problema, com equipamentos históricos se deteriorando e grupos sem condições de atuar pelos custos de manutenção de suas sedes, a associação a partir da consolidação de seu projeto de reabertura do TBC pretende também ampliar sua abrangência de forma a atuar e colaborar com soluções que possam manter o teatro brasileiro vivo. A possibilidade de parceria com programas governamentais, privados e colaborativos, bem como a assessoria, formação e capacitação que visem colaborar para gestão de projetos sustentáveis que garantam a manutenção dos teatros no Brasil são parte do universo da ATBC e de sua finalidade social: promover a cultura e a educação, com o propósito de incentivar e defender as artes cênicas brasileiras e sua dramaturgia, bem como preservar a memória e proteger o patrimônio cultural e histórico do teatro brasileiro.

Desde o início das reuniões do movimento pelo TBC em outubro de 2017, me faço presente junto aos associados à formação da ATBC na formulação de estratégias para atingir os entes diretamente ou indiretamente envolvidos nesse processo, ou que nele se inseriram a partir dessa mobilização. A associação e sua luta pela reabertura do TBC tiveram grande recepção por parte de entidades culturais governamentais e público-privadas como a FUNARTE e o SESC; entidades que empreenderam lutas semelhantes buscando consolidar seu espaço de atuação, como o Movimento dos Teatros Independentes de São Paulo (MOTIN), o Sindicato dos Artistas e Técnicos em Espetáculos e Diversões do Estado de São Paulo (SATED) e a Cooperativa Paulista de Teatro; e grupos de teatro com atuação destacada tanto em âmbito local quanto nacional, como o Teatro Oficina e o Satyros, na Praça Roosevelt. 
Para se pensar como esse processo chegou até aqui, esta dissertação trata da formação e consolidação de modelos de gestão de companhias e iniciativas teatrais a partir da $1^{\text {a }}$ metade do século XX com base em suas relações com entes públicos e privados desde a transição entre os grupos semiprofissionais e amadores/estudantis, passando pelas companhias que mantiveram sedes próprias como o $\mathrm{TBC}$, e que originaram outras a partir de artistas proeminentes saídos de suas bases - como as de Cacilda Becker e Nydia Lícia/Sergio Cardoso - trazendo seus desdobramentos até o momento atual, onde essas relações e seus alcances parecem ainda pouco estabelecidos com ações teatrais concretizadas através de uma dependência a iniciativas e políticas tênues que podem ser interrompidas a qualquer momento.

Cabe aqui ressaltar que as montagens das peças são consideradas muito mais como marco histórico, sem que haja um maior detalhamento dos seus aspectos técnicos e de execução. Estes são considerados apenas a partir de sua possível influência no padrão operacional das companhias analisadas, visto que a fortuna crítica sobre peças e trajetórias individuais de atores, diretores e mesmo de muitos administradores é bastante ampla, havendo farta documentação das mesmas através de outros trabalhos. Busca-se aqui concentrar esforços especificamente na análise dos modos de administração das companhias e na influência de tais ações no trabalho de grupos do período analisado e posteriores a ele. Da mesma forma, atuações em outras localidades além de São Paulo são colocadas a partir de experiências de companhias sediadas ou com base na cidade, e que com sua atuação nesses lugares tenham de certa forma inspirado ações e iniciativas duradouras, sob a mesma perspectiva que se coloca a respeito de companhias e profissionais estrangeiros considerados como influenciadores do modo de produção e do fazer teatral da cidade em vários momentos de nossa história.

Em relação à recuperação de conteúdo crítico, ressalto aqui as diferenças entre a crítica paulista e carioca de teatro, considerando principalmente o papel que a crítica carioca desde os anos 1940 até hoje realiza ao exaltar em suas resenhas ou reportagens todos os aspectos da ficha técnica de uma montagem, não apenas ou preferencialmente o desempenho dos atores, como normalmente se vê em São Paulo. Os dados sobre a produção, mais que sua execução por parte dos atores, acabam ficando mais evidentes 
nestas e por isso mesmo através delas são ressaltados êxitos ou fracassos de uma montagem a partir do interesse que estas geram no público.

Tais aspectos da análise crítica foram sendo trabalhados desde que Alfredo Mesquita buscou uma expressão própria para a crítica teatral em São Paulo a partir do convite a Décio de Almeida Prado para fazê-lo na revista Clima em 1941. Prado colocava didaticamente, segundo João Roberto Faria no segundo volume do seu livro “A História do Teatro Brasileiro" (2002), "um caráter analítico e especializado" (p.164) a respeito da evolução estética das companhias estrangeiras que vinham a São Paulo, sobretudo dos franceses com os quais teve contato em sua formação, Louis Jouvet e Jacques Copeau. Porém, mesmo ele tratava dos outros elementos - cenário, figurino e música - em função da "harmonia que envolve o teatro" (p.165) nas escolhas do diretor, e não na questão das resoluções para montagem de tal produção.

Isso se deu mesmo quando escrevia sobre as companhias brasileiras dos anos 1940, como a de Procópio Ferreira e Os Comediantes, ou em sua fase mais amadurecida após 1946, quando passou a escrever para $O$ Estado de $S$. Paulo tratando de levantar aspectos anteriores ao texto mais ligados “(...) à abordagem histórica, situando o autor em seu contexto literário e social” (p. 167). Nesse contexto, a crítica teatral do Rio a partir dos anos 1940 via o teatro um pouco além de suas questões internas, discutindo inclusive as implicações sociais da atuação do teatro de então, como no debate promovido por Abadie Faria Rosa às contestações à subvenção do então grande órgão oficial de fomento ao teatro fundado por Getúlio Vargas em 1937, o Serviço Nacional do Teatro (SNT), a grupos como Os Comediantes, que ao transitar do modelo amador ao profissional subverteria lógicas de mercado ajudando a criar novos modos de produção teatral no país.

Abadie aparentemente era a favor dessa separação como que para deixar o teatro profissional que surgia naquele instante de fora da "ação do favor oficial", mas também condenava certo “(...) surto de amadorismo subvencionado que oferece gratuitamente aquilo que o fazia mediante pagamento" (FARIA, 2002, p.170). Ao que pese o fato dele não ter proposto mudanças na estrutura quando à frente do próprio SNT em 1938, Abadie ataca uma questão que permanece em voga até hoje, a do quanto se deve pagar ao teatro, quer seja o poder público, os investidores ou o público na bilheteria, para 
mantê-lo funcionando para satisfação de todos os envolvidos no processo, inclusive os trabalhadores do teatro.

Visto isso, apesar de se centrar no teatro de São Paulo e especialmente em uma companhia de bastante sucesso não apenas na cidade como em várias regiões do pais dentro de sua parcela mais ilustrada, este trabalho se volta também a críticas escritas por jornais do Rio de Janeiro quando se trata do momento histórico da consolidação da companhia do TBC pois suas montagens, ainda antes de irem para o Rio para temporadas na cidade, eram bastante destacadas nos aspectos de sua produção de uma maneira diferente da crítica paulista, analisando e até mesmo influenciando nos rumos internos da companhia para além de suas composições estéticas, que de algum modo ainda serão lembradas no decorrer do trabalho.

No primeiro capítulo serão trabalhados os contextos prévios à fundação do TBC, pensando numa perspectiva histórica para se buscar as diferentes visões de formação do mercado brasileiro. São trabalhadas visões e pesquisas de diferentes historiadores do teatro como Charles Roberto Silva, em "Teatro Para os Trópicos: O Governo Imperial Brasileiro e a Questão Teatral (1822-1889)" (2017), e Joaquim Eloy Duarte com "D. Pedro II no Teatro" (2005), onde são tratadas questões a respeito do mercado teatral no período do Segundo Reinado e as primeiras relações entre o investimento público e privado que muitas vezes se entremeavam entre si em uma mesma iniciativa. Passando para o início dos grupos amadores de imigrantes, começa-se a tratar do caso de São Paulo na primeira metade do século XX a partir de onde se destacará a formação das escolas que fomentavam os grupos da cidade no período dos anos 1920 aos 1950, assim como os incentivos e interferências estatais sobre o teatro antes e após a ascensão ao poder de Vargas e a criação do SNT em 1937.

Ao se tratar dos grupos do início do século XX em São Paulo, são também apresentados os artistas amadores que se apresentavam em clubes no período como os "filodrammaticos" e estudantis-universitários, destacando principalmente os de Alfredo Mesquita (Grupo de Teatro Experimental - GTE; e Escola de Arte Dramática - EAD) e Décio de Almeida Prado (Grupo Universitário de Teatro - GUT), falando de suas formações, repertórios e legados a partir principalmente de "História do Teatro Brasileiro - Vol. I”, de João Roberto Faria (2012), “A contribuição Italiana ao Teatro Brasileiro - 1895-1964”, de Miroel Silveira (1976), “Cem Anos de Teatro em São 
Paulo", de Sábato Magaldi e Maria Thereza Vargas (2001), e "Uma Oficina de Atores EAD”, de Armando Sergio da Silva (1987).

No segundo capítulo, são investigados o papel dos mecenas individuais no período de consolidação do profissionalismo no teatro brasileiro com o TBC e as companhias fundadas a partir de sua experiência desde 1948, e o "caldeirão cultural" surgido dessas iniciativas em São Paulo que possibilitou a construção do TBC e de outros equipamentos culturais (MAM, MASP) através de próceres da iniciativa privada. Para isso, a pesquisa será baseada no livro de Maria Arminda Arruda "Metrópole e Cultura" (2001) e seu artigo "Empreendedores culturais imigrantes na São Paulo de 1950” (2005), além dos livros “Intérpretes da Metrópole”, de Heloísa Pontes (2011), e “Eu Vivi o TBC”, de Nydia Lícia (2007).

Após tratar da formação e dos percalços para consolidação do TBC, destaca-se o modo como a companhia se tornou centro de um modelo de profissionalização que perdurou por muito tempo através de suas montagens e da criação de companhias próprias por atores e encenadores que por lá passaram. Para aprofundar pesquisas nesse sentido, serão usados relatos de Nydia Lícia (2007) que apontam o momento em que se considera ter havido a transição definitiva da companhia TBC, de um modo de fazer teatro mais próximo dos grupos amadores no qual ela se originou para um teatro puramente profissional - o que ocorreu entre os anos de 1949 e 1950. Como reforço e contraponto a essa teoria, serão também usados Alberto Guzik e seu livro "TBC Crônica de Um Sonho" (1986), e "Ruggero Jacobbi” (2002), de Berenice Raulino, além de entrevistas de nomes como o empresário Franco Zampari e sua esposa Débora Zampari, reunidas na revista Dionysos, especial “TBC”, publicada pelo SNT em 1980, com textos bastante informativos e densos com balanços das atividades da companhia do TBC enquanto esteve ativa de 1948 a 1964.

Nesse período, este trabalho dá também destaque a um período chave do TBC em que se poderia dar uma possível transformação de seu modelo num movimento que acabou não se completando. Esse momento chave é aqui estabelecido na montagem pelo TBC em 1955 de "Santa Marta Fabril S.A.”, de Abílio Pereira de Almeida, quando se experimentou um grande êxito com o público em meio à um enorme prejuízo, pois enquanto a peça se tornou o texto brasileiro de maior sucesso até então, o teatro sofreu 
um incêndio em sua sede. Isso forçou uma mudança de rota para os planos de Franco Zampari, pois após o fechamento da Companhia Vera Cruz - empreendimento de cinema de Zampari que ajudava a custear as produções do teatro - houve uma crescente dependência de empréstimos públicos para sua manutenção que redundaram em decisões de resgate de textos e estéticas passadas que pareciam ter perdido lugar naquele momento.

$\mathrm{Na}$ busca de consolidar seu modelo de teatro enquanto tentava se recuperar rapidamente, o TBC seguiu na valorização do teatro produzido na Europa em busca de um público apreciador da "alta arte", mas que vinha sendo seguidamente desestimulado de assistir tais obras por diversos fatores. Assim, o TBC limitou qualquer iniciativa de valorização do dramaturgo nacional, deixando naquele momento essa tarefa para grupos que se fortaleceram, como o Arena que tomou a dianteira do teatro nacional a partir de então. Nesse sentido, será destacado o quanto a companhia pode ter perdido com essa iniciativa até entrar definitivamente em sua chamada "fase brasileira" a partir de 1960.

Pensando então na importância das iniciativas de Adolfo Celi, Cacilda Becker e Maria Della Costa para a consolidação de novos modelos profissionais a partir de companhias próprias, serão considerados os livros "Panorama Visto do Rio - Cia. Cacilda Becker" e "Cia.Tônia-Celi-Autran”, de Maria Inez Barros de Almeida (1987) e “Uma Empresa e Seus Segredos - Cia. Maria Della Costa”, de Tânia Brandão (2009), assim como as tentativas de consolidação dos autores nacionais dentro desse processo, usando como exemplos os casos de Jorge Andrade, Abílio Pereira de Almeida e Silveira Sampaio - alguns dos poucos autores nacionais encenados no TBC até os anos 1960 -, relatados em Guzik (1986), Lícia (2007), Barros de Almeida (1987), e na revista Dyonisos - “TBC” (1980).

Para falar desse período e de suas consequências, usou-se como referência principal o Acervo Gouvêa-Vaneau, hoje sob guarda de Celia Gouvêa, importante artista da dança paulistana e viúva de Maurice Vaneau, diretor artístico e geral do TBC em dois períodos, a virada da metade da década de 1950 e o início dos anos 1960, até o final da companhia em 1964. Serão analisados documentos preciosos relativos à administração do teatro por Vaneau, em uma ilustração importante para saber como o chamado "modelo TBC" implementado em tantas companhias teatrais a partir dos anos 
1950 foi se enveredando em práticas que terminaram levando o teatro a ficar à mercê de subsídios públicos constantes e uma política intervencionista que não deu plenas condições para o exercício do fazer teatral da companhia.

No terceiro capítulo, a partir de como o TBC foi reestruturado em 1964 após o fim da companhia que o ocupava, serão tratados de modo mais aprofundado o histórico da ATBC como associação em busca da reabertura do teatro após seu fechamento final em 2007, assim como sua relação com os grupos de teatro da cidade antes e durante essa mobilização. No quarto capítulo, pretende-se partir de modelos de gestão de companhias e projetos teatrais paulistanos, fundados no contexto da implantação do Programa Municipal de Fomento ao Teatro de São Paulo em 2002, para analisar possíveis correspondências e diferenças com o modo de trabalho do TBC e níveis de adequeção às políticas públicas e privadas em voga hoje, como os conceitos de economia criativa e organizações sociais (OS) a partir de obras como "Teatro e Vida Pública”, organizado por Flávio Desgranges e Maysa Lepique (2012).

Visto essa ser uma questão que perpassa o modo de se fazer teatro no Brasil desde o início da era moderna até hoje, será discutida a formação do "sistema" atual de financiamento teatral majoritariamente provido por recursos públicos e as possibilidades de manutenção de iniciativas próprias privadas, em um cenário onde mercado e políticas públicas parecem em constante movimento de formação e mudança, sem que se chegue á conclusão de um formato que abarque a todas as iniciativas de produção teatral.

Em relação a isto, serão considerados tambem grupos que se atenham por padrão a fonte de recursos específicos como prêmios/editais e incentivos fiscais. As conclusões levam em consideração o êxito alcançado na mobilização do meio teatral em torno do projeto de reabertura do $\mathrm{TBC}$ e as discussões sobre a viabilidade dos diferentes modos de produção avaliados, para tratar de como esse teatro histórico para a cidade e o país pode ainda ser um modelo para futuras ações e assim inspirar iniciativas teatrais, quer em uma possível reativação das atividades no prédio da Bela Vista, quer para outros grupos em diferentes condições de realização de suas obras artísticas.

Com efeito, pretende-se com este trabalho contribuir para a análise das políticas públicas de teatro no decorrer dos tempos modernos para assim pensar em diversas possibilidades de gestão e administração de teatros em um contexto como o que vivemos no país, em que se sente haver uma eterna tentativa de consolidação em meio a 
uma contínua reinvenção do modo de trabalhar com teatro, especialmente em uma metrópole dinâmica e em eterno movimento de transformação como São Paulo. Que aquilo que seja aqui colocado possa ser um alento na busca da preservação de uma memória dessa arte tão impermanente e fugaz como o teatro, para que desse modo ela sempre possa prosseguir agindo sobre nós com o mesmo impacto.

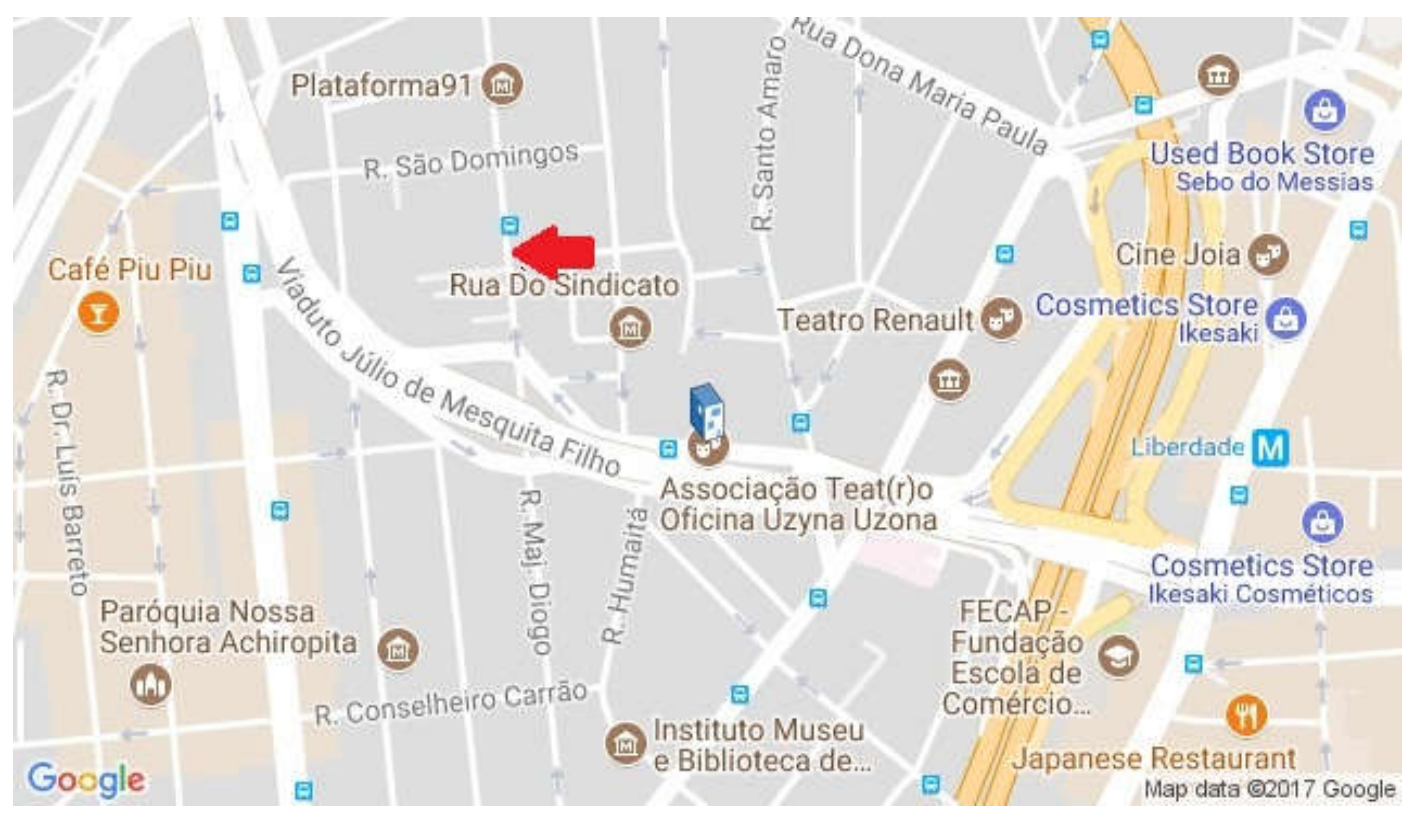

Imagem 2 - Localização do TBC no mapa do bairro da Bela Vista (sinalizada pela seta), com destaque na mesma região para os prédios do Teatro Oficina Uzyna Uzona, sede do grupo de teatro de vanguarda desde os anos 1950, e o Teatro Renault, teatro privado patrocinado desde 2001 e local de exibição de franquias de musicais da Broadway nos tempos atuais. Fonte: Google, 2017 


\section{CAPÍTULO 1: Financiamento Público e Privado Pré-TBC}

\subsection{Segundo Reinado}

Quando se trata de teatro profissional, é possível que tenhamos uma ideia préconcebida do que isso seja a partir de uma base conhecida sobre a engrenagem teatral, ou mesmo com correspondências primárias ao trabalho de escritório ou qualquer atividade econômica conhecida, onde a analogia entre as hierarquias paralelas seria estruturada de modo semelhante aos olhos de quem a vê de fora. Para quem tem mais familiaridade com o teatro como ele é hoje, a figura do diretor de palco, dos atores e atrizes a ele subordinados, e dos técnicos que ajudam o teatro a acontecer se contrapõem a este trabalho de escritório realizado pelos diretores e gerentes de uma companhia.

Contudo, não é possível colocar esse tipo de pressuposto sob uma perspectiva histórica de teatro, ou mesmo sobre o sentido do profissionalismo nos diferentes contextos sociais do país ou mesmo da cidade de São Paulo. Pensando nas inúmeras diferenças em como o país é constituído nos séculos XIX ou início do XX em relação aos dias de hoje, é preciso considerar que mesmo que haja práticas e iniciativas parecidas com as que vivemos, elas também se baseavam em modelos mais próximos ao seu próprio período, considerando os diferentes arranjos da sociedade e do poder constituído. Nesse sentido, a relação do poder público e dos entes privados com tal arte também se dava de maneiras particulares.

Pensando no Segundo Império, quando as cidades brasileiras ainda estavam organizando seu ordenamento social, mecanismos de financiamento teatral se colocavam á disposição dos então onze teatros da Corte sediado na capital Rio de Janeiro, freqüentado por cidadãos com plenos direitos e integrantes dessa Corte. ${ }^{1}$ Desde os anos 1820, e principalmente no apogeu dessa política após 1850, a posição perante a arte teatral dada pelo Imperador Dom Pedro II alimentava a construção de uma unidade nacional onde esta, apesar de considerada uma "atividade comercial" especial, era vista pelo monarca como parte do processo de formação educacional do país.

\footnotetext{
${ }^{1}$ A Corte era composta pela Família Imperial e por funcionários por ela mantidos - incluindo escravos em todo o país. Segundo o Censo Demográfico de 1872, primeiro realizado no país, a Corte consistia em 273.972 pessoas, dentre estas 48.939 escravos. Como comparação, apenas na cidade do Rio de Janeiro o número de "cidadãos" na época era de 490.087. Fonte: IBGE
} 
Tal movimento de certa forma pode ser ilustrado por algo acontecido em 1824, ainda no reinado de D. Pedro I, quando para salvar o Real Theatro de São João recém destruído por um incêndio, o Imperador ajudou na obtenção de empréstimo no Banco do Brasil ao empresário Fernando José de Almeida. Alem do referido empréstimo, o empresário recebeu a concessão de algumas loterias em prol da manutenção do teatro, em troca da construção de um camarote imperial no teatro, que a partir de Decreto de 15 de setembro de 1824 passou a se chamar Imperial Theatro de São Pedro de Alcântara, nome atribuído por sugestão de Almeida.

Este teatro, apesar de arrendado por Almeida, teve em 1830 a concessão de um novo decreto para utilização de recursos de loterias com arrecadação do Governo, para cobrir “(...) a bilheteria deficitária e a impossibilidade de gerir o negócio teatral por falta de recursos financeitos (sendo este) o mote principal para o requerimento de loterias no período imperial" ${ }^{\prime 2}$. Nesse momento, ele era o único teatro efetivamente subsidiado do Império, enquanto os outros se mantinham em associações particulares, formadas a partir da sociedade civil - desde “(...) homens livres pobres a ricos negociantes de exportação e tráfico de escravos"3 - interessados em exercer e apreciar a arte teatral.

Com o poder central altamente concentrado no Rio de Janeiro, foi criado o Conservatório Dramático Brasileiro (CDB) em 1843 como “(...) uma ligação direta do Governo com a atividade teatral" (DUARTE DOS SANTOS, 2007) e também um órgão de promoção de manifestações culturais de toda a Corte, ainda que sob estrito controle estatal do conteúdo. João Caetano dos Santos, então um dos mais prestigiados artistas do regime monárquico como ator principal da companhia teatral residente no Teatro Imperial, chegou a ser parecerista ajudando a aprovar ou reprovar apresentações propostas tanto para o próprio Conservatório como para os teatros da Corte, no que pode ser um exemplo de atuação da burocracia estatal no teatro do Brasil que “(...) após o processo de independência não rompeu imediatamente com as normas da burocracia estatal portuguesa que migraram para os trópicos"4

\footnotetext{
${ }^{2}$ SILVA, 2017, p. 203

IIbid., p. 193

${ }^{4}$ SILVA, Op. Cit., p. 217
} 
Essa pode ser considerada uma mostra do caráter dúbio com que o Segundo Reinado lidava com a arte teatral. A constituição desse que poderia ser considerado o primeiro órgão de apoio às manifestações teatrais se converteu no primeiro tipo de aparato censor estatal de que se tem notícia no país. É possível pensar inclusive que o órgão trabalhasse quase que especificamente para a censura de espetáculos, apesar de que sua função principal parecia ser primordialmente a de servir de órgão conselheiro para a monarquia a respeito do estado da arte teatral no país naquele momento.

Um questionamento que poderia ser feito a respeito dessa atuação era o quanto os critérios morais eram predominantes para se tomar uma obra como válida de ser apresentada, e essa dúvida parecia estar no âmago de tal órgão desde seu início. Para o poeta Manoel de Araújo Porto Alegre e o padre Januário da Cunha Barbosa, que ajudaram a fundar o $\mathrm{CDB}$, ela teria por finalidade "promover os estudos dramáticos e o melhoramento da cena brasileira, de modo que esta tornasse a escola dos bons costumes e da língua" 5 . Isso foi reforçado por uma Resolução Imperial de 1845 onde caso uma peça fosse considerada, no crivo do $\mathrm{CDB}$, "pecaminosa contra a veneração à Nossa Santa Religião, contra o respeito devido aos Poderes Públicos da Nação e Autoridades constiuídas e contra a guarda da moral e decência pública" (LEMOS, 2014, p. 9), ela teria sua exibição vetada no Império. A única exceção colocada pela Resolução dizia respeito especialmente às peças que “(...) pecassem contra a castidade da língua (onde) seriam apontados os defeitos, mas não negada a licença."

Nessa tentativa de estabelecer um controle maior sobre o conteúdo teatral, a fiscalização era feita não apenas por emissários do governo, mas por pessoas da própria soceidade civil dispostos a examinarem as peças da maneira que o Império esperava, como faziam o poeta Gonçalves de Magalhães e o dramaturgo Luis Carlos Martins Pena. Porém, muitas vezes o caráter consultivo da CDB acabava sobressaindo, por parte de pareceristas que buscavam legitimar toda forma de expressão popular no teatro feito no país, como foi o caso de um parecer escrito por um jovem Machado de Assis dizendo que “(...) o teatro é para o povo o que o coro era para o antigo teatro grego (...), deve identificar-se com o fundo das massas, copiar, acompanhar o povo" ${ }^{\circ}$.

\footnotetext{
${ }^{5}$ LUCCHESI, Marco. “Uma cartografia notável”, in: LEMOS, 2014, p. 9

${ }^{6}$ Ibid., p. 10
} 
O maior controle estatal sobre as artes consolidava um aparelho administrativo cada vez mais burocrático em um regime monárquico que, segundo Leal (1948), se tornou ainda mais centralizador na concessão de recursos às províncias a partir de $1840^{7}$. No entanto, isso não limitou ações privadas para a arte teatral, por mais paradoxal que possa parecer. Em 1855, o empresário Joaquim Heliodoro Gomes dos Santos resolveu arrendar o pequeno Teatro de São Francisco de Paula e após reformas necessárias inaugurou nele o Ginásio Dramático do Rio de Janeiro. Era uma companhia liderada por ele, mas que contou com uma característica particular naquele momento de delegar a função de ator "ensaiador" para outra pessoa da companhia: primeiro o francês Emilio Doux, e no ano seguinte o português Luis Candido Cordeiro Pinheiro Furtado Coelho.

Furtado Coelho era um ator e encenador português que começou a trabalhar no Brasil em experiências com o chamado teatro realista, tomando por base ideias trabalhadas na França naquele momento, como “(...) a estruturação de cena e a disposição cênica dos objetos em consonância com a reprodução da realidade" ${ }^{\text {, em um }}$ modo de trabalho que acabaria por nortear todo a produção do Ginásio Dramático, visto que o local homenageava o teatro homônimo de Paris “(...) onde eram encenadas as peças realistas" ". A companhia era do agrado de Dom Pedro II e sua família, que assistiram "cerca de trinta récitas" (DUARTE DOS SANTOS, 2007) da companhia entre 1855 e 1860, e respeitada ao introduzir obras identificadas com esse gênero, entre elas “A Dama das Camélias", de Alexandre Dumas Filho, e uma peça considerada a primeira peça do teatro de revista brasileiro, "As Surpresas do Senhor José da Piedade", de Justino de Figueiredo Novaes, encenada em 1859.

Sua influência foi tal que o empresário João Ferreira Bastos, de Porto Alegre, o convidou para integrar o elenco da companhia do Ginásio Dramático Rio-Grandense em 1857. O Ginásio de Porto Alegre havia sido fundado por influência da companhia parisiense em 1854, portanto um ano antes do homônimo do Rio, curiosamente como reação a uma visita de João Caetano ao Rio Grande do Sul que acabou não incluindo Porto Alegre em seu roteiro - apenas as cidades de Rio Grande e Pelotas. Nisso, a

\footnotetext{
${ }^{7}$ LEAL,Victor Nunes. Coronelismo, Enxada e Voto, São Paulo, Cia. das Letras, 1948, apud CARVALHO FRANCO, 1997, p. 121.

${ }^{8}$ GONÇALVES; LEVIN, 2014, p. 108

${ }^{9}$ FARIA, 2012, p. 123
} 
Companhia Dramática Teatral, fundada em 1833 e desde então instalada no Teatro São Pedro de Porto Alegre, mudou seu nome e ajudou em sua trajetória a fomentar uma integração entre capital e interior, em um primeiro esforço privado de integração de uma política teatral.

Ainda que considerássemos que o fato de tal iniciativa teatral inspirada em similares da Europa ter sido realizada em uma cidade fora dos grandes centros antes mesmo da grande metrópole do país pudesse ter alguma responsabilidade da aparente falta de trato diplomático do artista teatral então mais próximo à Corte, João Caetano, aquele momento histórico era favorável a uma configuração de companhia teatral que seguia predominantemente o exemplo dado por ele nos grupos então chamados de "profissionais", e assim foi por praticamente todo o período até o fim da primeira metade do século XX.

Essas companhias eram lideradas por um artista principal que monopolizava atenções, um divo ou diva que “(...) prosseguiam na valente tradição de representar ao mesmo tempo um texto e uma nação" ${ }^{\text {10 }}$. Eles eram figuras oficiais da arte que buscavam representar, sendo ao mesmo tempo empresários de si mesmos e da companhia, dando a elas o ar de seriedade necessário para que o público considerasse estar consumindo a mais fina cultura de sua sociedade. O próprio Furtado Coelho, após passar por Porto Alegre em 1857, retornou ao Rio para ser primeiro-galã do Ginásio Dramático - ou seja, tornou-se ele próprio um divo, tal como João Caetano.

Dom Pedro II decididamente acreditava nessa definição de alta cultura, pois era a partir de suas próprias viagens pela Europa que construiu a concepção do teatro como um dos meios de educação do povo cidadão do país. Ele, como ávido consumidor cultural, buscava o modelo da Comedie Française não só para ver e ouvir aquelas que eram as grandes deusas da cena em sua época, como Sarah Bernhardt e Eleonora Duse. Nessas viagens ele também praticava muito bem a diplomacia para com esses artistas, presentando-os com joias brasileiroas e lembranças para convidá-las a eventualmente se apresentarem no Brasil para seus súditos. Desse modo, Eleonora Duse em 1885 foi apresentar a "Dama das Camélias" no Teatro Imperial São Pedro de Alcântara.

${ }^{10}$ SILVEIRA, 1976a, p. 64 
Porém, D. Pedro ainda não havia construído até o fim de seu reinado uma política cultural que fosse além da metrópole de então, o Rio de Janeiro, aparentemente desconsiderando acesso à cultura aos cidadãos livres e de sua Corte residentes em outras partes do país, notoriamente Minas Gerais e Bahia, ainda os estados mais populosos do Brasil durante seu reinado. Analisando sua política cultural de modo mais distanciado, ela pode ser perfeitamente considerada como do tipo distributiva, onde as decisões tomadas sobre as prioridades na aplicação dos recursos não levariam em consideração as limitações orçamentárias, ao mesmo passo que tinham impacto individualizado e bastante limitado, com tendência a se tornarem desagregadoras graças às disputas pelos recursos e descontinuadas a médio e longo prazo.

Víde como exemplo as comissões no Senado e na Câmara que desde a década de 1850 passaram a sistematizar destinação específica de recursos para companhias teatrais, após a proibição do Imperador pela utilização das loterias para esse fim após anos de concessões nesse sentido. Poucos anos após a implementação dessa política, as prioridades para destinação dos recursos eram dadas para se cobrir prejuízos de casas e companhias teatrais, a partir de intervenções governamentais tomadas por decretos do Imperador. Isso ocorreu no próprio Teatro Imperial, que era visto pelos deputados como deficitário e oneroso às finanças públicas sem que houvesse contrapartida. A figura do inspetor, surgida por ação deles em 1850, a controlar os gastos externos das comissões acabou ficando esvaziada desde a sua instituição.

Desse modo, é curioso pensar que o Estado brasileiro que tanto dizia se espelhar em modelos europeus para a cultura, que evocava expressamente Luis XIV ao dizer que as artes eram uma parte central das políticas e intenções de seu reinado, agia na questão cultural segundo uma concepção liberal de Estado. Esse modelo se consolidou nos Estados Unidos a partir da sua Constituição de Independência em 1792, e se tornou predominante nas políticas públicas do país até o final do século XIX, inclusive na cultura. Entretanto, apesar do Estado de então praticar certo liberalismo ao não ser contra a competição dos teatros particulares frente aos da Corte, buscava interferir em sua administração quando achasse conveniente, como mostram as intervenções a partir da segunda metade do século XIX. 
É de certa forma irônico que um governante como Dom Pedro II buscasse então retomar práticas de um Estado constituído, como na Europa, junto a políticas de um Estado novo - os Estados Unidos - ao mesmo tempo em que a sociedade brasileira e o acesso desta ao teatro se assemelhavam mais à Grécia Antiga. Isso porque no Império brasileiro, reproduziam-se convenções trazidas do tempo colonial onde “(...) escravos e mulheres desacompanhados no espaço do teatro eram tratados como caso de polícia"11. Ou seja, sequer havia a contrapartida dada pelos gregos nos festivais dionisíacos, onde a entrada era aberta tanto para "homens livres" - os únicos considerados cidadãos plenos então - como para mulheres e escravos.

Tais contradições não foram empecilho para que houvesse uma continuidade do regime monárquico por tanto tempo na vida do país, sem maiores sobressaltos e questionamentos da sociedade civil, mesmo porque a maior parte da população do país ainda se concentrava na região agrícola, longe das cidades. ${ }^{12}$ Contudo, os movimentos de pressão econômica do exterior junto à crescente oposição da intelectualidade frente à escravidão traziam cada vez mais prejuízos para a manutenção desse sistema, sendo um problema para a continuidade de quaisquer políticas do reinado, principalmente em área tão sensível às oscilações externas como a cultura.

Os problemas políticos do final do período imperial fizeram com que o Estado se afastasse da subvenção ao teatro. Porém, mesmo com a queda definitiva da monarquia em 1889, políticas oficiais eram discutidas regionalmente através de propostas de construção de grandes teatros municipais para se contrapor aos que eram de propriedade ou arrendados à Corte. Essas discussões sobre os novos teatros tinham como modelo o Teatro Amazonas, que começou a ser planejado em 1882 e é um exemplo perfeito da política oficial predominante naqueles tempos. Apesar de ser uma iniciativa para agradar aos barões que dominavam o comércio de borracha na região de Manaus para Europa e Estados Unidos, o teatro foi colocado em discussão como algo de interesse público pelo deputado José Fernandes Junior, que propôs à Assembléia do Amazonas a sua construção em 1882 .

\footnotetext{
${ }^{11}$ SILVA, Ibid., p. 192.

12 Homens "livres" do campo trabalhavam em serviços relacionados à produção e comercialização de café, realizando tarefas residuais não oferecidas aos escravos, como o transporte de sacas em lombos de burro, e outras onde se estabelecia uma relação de compadrio entre o fazendeiro e o trabalhador, como se dava com os sitiantes e agregados. Cf. em CARVALHO FRANCO, 1997, p. 65-114.
} 
Muito pelos problemas na sua viabilização por causa da falta de investimento dos doadores da indústria da borracha, que seriam os primeiros beneficiados com sua abertura, o ritmo de sua construção permaneceu lento desde seu início em 1884. Isso se deu até o governo de Eduardo Ribeiro em 1890 trazer com recursos públicos profissionais de alto gabarito paraa terminar a obra, para assim fazer Manaus entrar no circuito dos grandes artistas europeus que ocasionalmente vinham aos grandes centros do Brasil para assim animá-los a também se apresentarem na cidade.

Dom Pedro II não ficou no poder para ver tal obra ser finalizada, e assim poder apreciá-la como gostaria em um camarote imperial, pois seu reinado acabou deposto ainda em 1889, com ele e sua família experimentando um exílio forçado no exterior. Assim, a mudança de regime ocorrida pela intervenção dos militares liderados pelo Marechal Deodoro da Fonseca, que instituiu a República no país, fez com que as coisas demorassem um tanto mais para começarem a tomar outro rumo de crescimento. De maneira mais uniforme, mesmo nos grandes centros, em busca de uma normalização na vida teatral do país de forma a que esta se tornasse algo consolidada na vida nacional.

\subsection{São Paulo e os "Filodrammaticos"}

Dentro do contexto imperial, a cidade de São Paulo no fim do século XIX ainda era uma cidade de cultura eminentemente rural, cuja economia girava em torno da cultura cafeeira mantida pelos latifúndios que se espalhavam pela cidade e escoavam sua produção rumo ao Porto de Santos, para de lá ganharem o mundo. A cidade tinha um grande teatro no Largo São Gonçalo (atual Praça Doutor João Mendes) construído pelo poder público, o Teatro São José ${ }^{13}$. Sua construção foi autorizada pela Assembléia Legislativa em 1854 e, mesmo considerada finalizada em 1864, o teatro era continuamente reformado por falhas em sua estrutura interna.

Questionamentos quanto ao financiamento do teatro por parte do Estado eram constantes, principalmente pelo fato do governo estadual tê-lo concedido a Antônio Bernardo Quartim - dono da antiga Casa de Ópera da cidade, na região do Pátio do Colégio, e também administrador do Jardim Público (hoje Parque da Luz) - para que

${ }^{13}$ Cf. em LOUREIRO, Edison. O Começo e o Fim do Teatro São José. In: São Paulo Passado, 8 de agosto de 2015. Disponível em <https://saopaulopassado.wordpress.com/2015/08/08/o-comeco-e-o-fim-doteatro-sao-jose/>. Acessado em 12 de julho de 2019 
este explorasse o espaço do novo teatro por dez anos após sua conclusão, que então nunca era sacramentada apesar do local receber espetáculos desde então. Foi preciso haver intervenção do presidente da Assembléia Legislativa, Saldanha Marinho, para que fossem abertas investigações quanto à concessão. Tais investigações foram instauradas apenas em 1870 e concluídas três anos depois, fazendo do São José patrimônio encampado pelo poder público, acelerando sua finalização ocorrida em 1876.

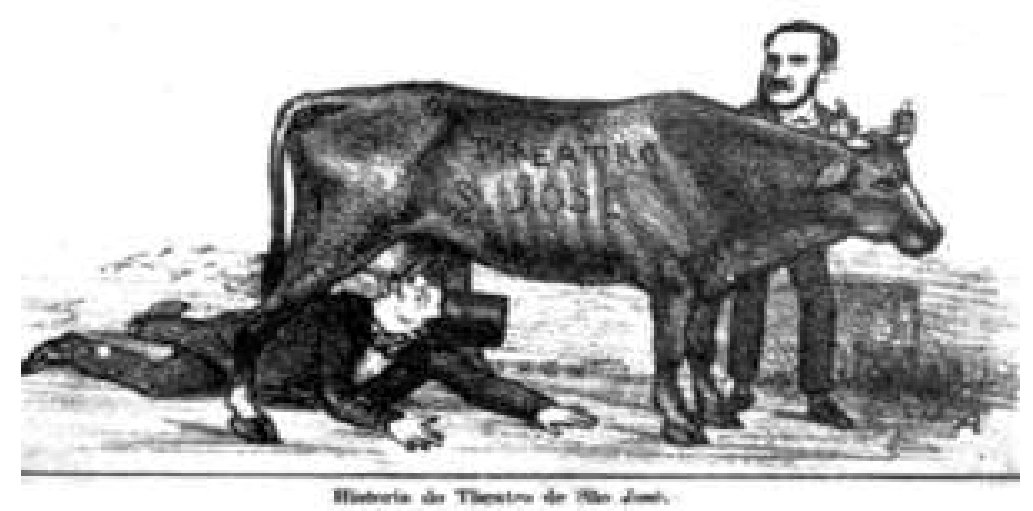

Imagem 3 - Charge de Ângelo Agostini publicada na revista $O$ Cabrião em 1867, intitulada "História do Teatro de São José", onde os recursos do poder público, representados pela vaca emagrecida do Teatro São José, tem Antônio Bernado Quartim a "mamar em suas tetas". (LOUREIRO, 2015)

A composição social da cidade facilitava certa desagregação, em um cenário onde comunidades buscavam uma maior integração através da construção de pontes sobre os rios Tamanudateí, Tietê e Pinheiros que ligaram bairros em formação ao leste, norte, oeste e sul da cidade ao centro. Os pilares de unidade convencional entre estas comunidades, ou o que poderíamos chamar de cultura coletiva, se davam através da Igreja Católica e dos encontros sociais na zona comercial já existente no centro. $\mathrm{O}$ debate público na Câmara ainda girava muito em torno das questões mais básicas de infraestrutura, tratando da construção de ruas e seus calçamento e saneamento insuficientes, além de um grande problema com animais circulando soltos por essas vias ainda bastante estreitas. ${ }^{14}$ A cidade passava ao largo das grandes discussões abolicionistas dada a pouca influência que a região ainda tinha sobre a política nacional, apesar de seu crescimento econômico começar a se tornar notório.

\footnotetext{
${ }^{14}$ Cf. em ASSUNÇÃO, Paulo de. A cidade de São Paulo no século XIX: ruas e pontes em transformação, in: Revista do Arquivo do Estado de São Paulo, n. 10, ano 1, 2006. Disponível em <http://www.historica.arquivoestado.sp.gov.br/materias/anteriores/edicao10/materia03/texto03.pdf> Acessado em 10 de julho de 2019
} 


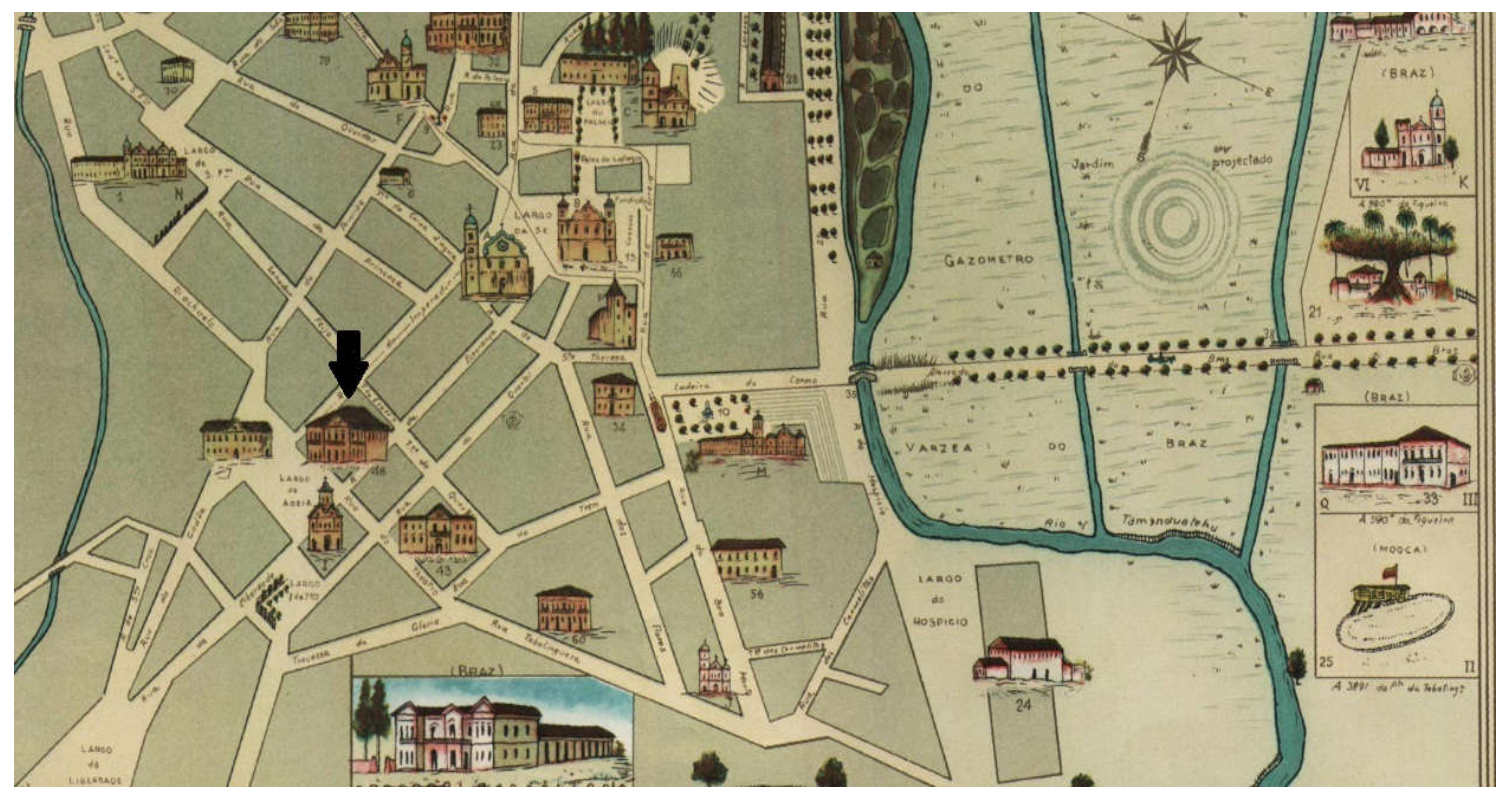

Imagem 4 - Mapa da cidade de São Paulo em 1877 (com indicação do Teatro São José por seta à esquerda). Um pouco acima está o Largo da Sé, com a antiga Catedral (demolida em 1911) onde hoje está o prédio da Caixa Cultural - a atual Catedral foi construída de costas para a Praça João Mendes, onde estava o São José. Fonte:Departamento de Patrimônio Histórico (PREFEITURA DE SÃO PAULO, 1954)

De certo modo, suas elites não estavam satisfeitas com a marginalidade a que o reinado de Dom Pedro II relegava São Paulo, ao mesmo tempo que a Abolição ganhava corpo entre a família imperial até ser definitivamente proclamada em 1888. Essas elites viam de longe suas tensões com a monarquia agravadas pelas questões do Imperador com a Igreja de Roma, e a crise no Exército após a Guerra do Paraguai que culminou na falta de pagamentos aos sobreviventes e familiares dos mortos. Isso foi fundamental para a ascensão de insurrentes que, em movimento militar liderado no Rio de Janeiro pelo Marechal Deodoro da Fonseca, instaura a República em 15 de novembro de 1889.

O Estado de São Paulo foi o primeiro a aderir oficialmente à República, em 18 de novembro de 1889, com o Decreto N.1 do Governo Provisório do Estado assinado por Prudente Moraes Barros, Joaquim de Souza Mursa e Francisco Rangel Pestana. O fato de São Paulo ter contribuído para o movimento através da fundação anos antes do Partido Republicano Paulista, em 1873 na cidade de Itu, contribuiu para que finalmente o estado se sentisse protagonista político dos rumos da nação. Uma consequência desse protagonismo foi a aprovação de reformas propostas para o Porto de Santos desde $1879^{15}$ e que, com seus recursos liberados, finalmente foram finalizadas para que houvesse sua reinauguração oficial em 1892.

\footnotetext{
${ }^{15}$ Os planos da reforma do Porto de Santos, desde 1872 já o maior do país, foram feitos pelo engenheiro Theodoro Sampaio e publicados na Revista de Engenharia de 10 de agosto de 1879
} 
É preciso salientar que São Paulo vinha lentamente experimentando certa mudança no seu perfil cultural ainda nos tempos do Império. Por volta de 1880, São Paulo passou a receber a visita de atrações que viam preferencialmente ao Rio de Janeiro e utilizavam espaços como o Teatro São José para estender suas turnês de apresentação para esta cidade. A apresentação de artistas como Sarah Bernhardt, Gustavo Modena, Ernesto Rossi e Eleonora Duse, italianos que encenavam peças francesas e britânicas, além de óperas italianas, incentivou a organização de sociedades amadoras dramáticas com funções específicas e sessões de apresentação próprias que não eram abarcados pelas políticas prévias do Estado. Entretanto, todo esse movimento cultural sofreu um baque com a destruição do São José por um incêndio em 1898.

Em reação a isso, a arte estabelecida nesses grandes espaços teatrais tratou de logo encontrar nova guarida do poder constituído. As Câmaras do Rio e de São Paulo seguiam em discussão pela construção dos Teatros Municipais nessas cidades para encampar companhias oficiais de atores dramáticos e de ópera junto a músicos de orquestra mantidos pelo poder público. No caso de São Paulo, o Teatro Municipal traria para si oriundos daquela que foi a primeira escola dramática superior da cidade, o Conservatório Dramático e Musical de São Paulo, em contraposição ao Liceu de Artes e Ofícios (LAO), aberto em 1873 com caráter técnico inspirado nas escolas de Arts \& Crafts inglesas. A implementação do Conservatório tem uma história curiosa, pois este foi construído como uma iniciativa privada que se tornou em parte pública.

Em 1904 o Conservatório foi pensado por João Gomes de Araújo e Pedro Augusto Gomes Cardim, com inspiração no Conservatório Francês, alugando o antigo prédio da Marquesa de Santos na Rua Brigadeiro Tobias. Erguido como empreendimento privado tal como o Liceu, levou-se dois anos na implementação do projeto até sua inauguração em 15 de março de 1906. Paralelo a isso, desde 1886 havia também um prédio na avenida São João pertencente a Frederico Joachim que, após se tornar representante da fabricante de pianos Steinway \& Sons em 1895, foi montado junto a um hotel como local para aulas de música e concertos no chamado Salão Steinway. 
Em 1909, Frederico vendeu seu prédio para Luis Landró, então vereador na cidade. A diretoria do Conservatório se aproveitou da situação e propôs a Landró que o prédio continuasse tendo aulas de música, além de arte dramática, sob gestão da própria equipe do Conservatório. Para isso, eles ainda conseguiram através de Landró “(...) uma verba junto ao governo de cem contos de réis (para a reforma do prédio) apesar de haver recursos próprios" ${ }^{\$ 16}$ do Conservatório para tanto, através do pagamento dos cento e trinta e quatro alunos regulares de seu curso de três anos (mais quarenta e oito que cursavam gratuitamente). Por fim, o Conservatório conseguiu retomar aulas no mesmo ano, ainda que o alvará dessa modificação na planta interna só tenha saído em 1930.

Porém, o movimento mais vibrante e duradouro do teatro paulistano da primeira metade do século XX se deu através do movimento dos grupos dramáticos amadores. Esses grupos foram criados a partir do vácuo das políticas públicas que fazia com que artistas que não eram ligados a companhias estabelecidas se tornassem marginalizados perante o reconhecimento oficial. Essa nova forma de associação permitiu que, no longo período em que a subvenção era limitada aos grandes teatros municipais construídos no Rio de Janeiro e em São Paulo, e aos conservatórios criados como escolas dramáticas, surgissem grupos dramáticos feitos por imigrantes recém-chegados, na maioria italianos, trazendo a tradição dos chamados grupos filodrammaticos que passaram então a se espalhar pelo país, mas principalmente em São Paulo, por ser esta a cidade com a maior concentração de imigrantes italianos no Brasil ${ }^{17}$.

O termo filodrammatico, que significa "simpatia pela arte dramática", foi concebido a partir das expressões que culminaram no chamado "Risorgimento Italiano", movimento da primeira metade do século XIX que teve seu auge na década de 1860 . Este movimento consolidou o processo de unificação da Itália através das campanhas militares de Giuseppe Garibaldi, as proposições políticas e filosóficas de Giuseppe Mazzini e as exaltações ao sentimento da pátria na lírica e na prosa de Alessandro Manzoni e Edmondo di Amicis. A península que era dividida em diversos reinos se tornou em 1871 o Reino da Itália, sob o reinado de Vittorio Emanuele II, então monarca do Reino da Sardenha.

\footnotetext{
${ }^{16}$ AZEVEDO, Elizabeth Ribeiro. Conservatório Dramático e Musical de São Paulo: pioneiro e centenário. In: Revista do Arquivo do Estado de São Paulo, n. 16, 2013. Disponível em: <http://www.historica.arquivoestado.sp.gov.br/materias/anteriores/edicao16/materia01/texto01.pdf> Acessado em 10 de julho de 2019

${ }^{17}$ Sobre o número de italianos vindos para o Brasil e São Paulo, Cf. em SILVEIRA, 1976a, p. 15-9
} 
As bases de construção desse pensamento italiano que foi derrotado politicamente pela ascensão da monarquia permaneceram fortes entre o povo que de lá emigrou, se consolidando na sociedade paulistana. Esse pensamento se difundia através de jornais próprios da comunidade como o Fanfulla (o mais antigo, fundado em 16 de junho de 1893), La Tribuna Italiana e Avanti, e associações de auxílio e recreação (chamadas de "societá di mutuo socorso", sociedades de ajuda mútua). O sentimento predominante nestes italianos que chegavam ao Brasil em relação ao teatro era de “(...) entretenimento para promoção e comunhão de ideias dos diversos núcleos que chegaram à cidade" (FARIA, 2012, v.1, p. 358) em um ambiente de confraternização entre os grupos, não importando se as encenações fossem de peças ao modo da commedia dell'arte ou dramas e comédias de costumes, afinal as apresentações eram sempre finalizadas com um baile (SILVEIRA, 1976a, p. 64).

Esses grupos tinham identidade e coesão interna muito fortes, pois além de mostrarem e realçarem seu caráter nacional no fato dos seus respectivos nomes estarem escritos em italiano, também era estampado neles em muitos casos sua filiação políticosocial - se operária, progressista ou anarquista -, localização geográfica dentro da península, ou mesmo o nome do seu patrono ou divo/diva de inspiração, quer este fosse histórico ou contemporâneo. Assim, quem era da comunidade e buscava se filiar a um grupo específico não se enganava em encontrar pessoas com sotaques, pensamentos e gostos semelhantes.

Apesar de contar com amadores em sua grande maioria, considerando que não tinham experiêcia artística anterior e exerciam atividade não remunerada, muitos grupos contavam com estrutura administrativa interna e um "diretor dramático" geralmente estrangeiro com funções específicas na companhia teatral, como o Andrea Maggi ${ }^{18}$, caracterizando-o como um entre vários grupos que ao menos “(...) não se contentavam mais com o simples amadorismo" "19. Essa composição cresceu com o tempo, conforme as produções teatrais se aprimoraram, principalmente após 1900. Porém, o padrão dos grupos nesse início mostra a maneira coletivista com que viam o trabalho teatral:

${ }^{18}$ Baseado na rua Major Diogo, 57, “(...) onde cinco décadas depois estaria o TBC"; esse foi um dos chamados "grupos relâmpago". In: SILVEIRA, 1976a, p. 62; Cf. na p. 39

${ }^{19}$ MAGALDI ; VARGAS, 2001, p. 33 
Era idêntica a estrutura das sociedades organizadas por contemporâneos com aqueles mesmos fins de agrupar, reanimar, proteger, recrear e instruir os companheiros de aventura americana. Como os elencos tradicionais italianos, onde o "capo-comico" era ao mesmo tempo chefe da cooperativa artística, diretor de cena e professor de arte dramática, também entre os amadores o primeiro ator era aquele que já tinha alguma experiência assimilada, orientava o conjunto, ensaiava e ensinava formando novos atores. ${ }^{20}$

Somente havia uma distinção entre as Societá, Circolo e os Club Filodrammatici quanto à restrição de entrada de pessoas. Se dois primeiros tipos o ingresso custava em torno de dois contos de réis e podia ser comprado por qualquer pessoa que entendesse italiano - as peças eram reproduzidas nesse idioma -, no terceiro tipo de associação as apresentações eram restritas aos sócios que pagavam mensalidade de até quinhentos réis mensais, valor esse cobrado por grupos que queriam “(...) reduzir a possibilidade do prazer descompromissado (da parte do público), mostrando o grupo teatral como uma forma de trabalho doutrinário" ${ }^{21}$, com entrada livre apenas em eventos marcados como beneficentes.

Nos registros do jornal Fanfulla, há menção a um grupo que mudou sua razão social de Societá para Club - o grupo Vittorio Alfrere, fundado em 1897 e que passou no ano seguinte a ter 270 sócios após essa mudança de razão social. Importante ressaltar também a menção ao Circolo Francesco Morosini, que após ter sido fundado em 1898 no Salão Excelsior na Rua Florêncio de Abreu, teria originado após o seu fím o único grupo social da época que permanece ativo até hoje - o Circolo Italiano, sediado no Edifício Itália, na Rua Ipiranga, desde 1911.

Mesmo antes da virada do século XIX, a atividade dos grupos filodramáticos na cidade de São Paulo foi muito intensa. Segundo registros do jornal Fanfulla, somente entre 1895 e 1900 foram destacados dezesseis grupos atuantes em várias regiões da cidade de São Paulo - Centro, Luz, Bom Retiro, Brás, Bixiga, Cambuci, Barra Funda e Lapa. Eles ocupavam em sua maioria sedes próprias nessas regiões, porém muitos grupos ainda se voltavam à ideia de ocupar espaços maiores e já constituídos, como o Politeama do Brás, o Teatro Sant'Ana e o Teatrinho do Cambuci (também chamado de

\footnotetext{
${ }^{20}$ SILVEIRA, 1976a, p. 33

${ }^{21}$ VARGAS; ALVES DE LIMA, 1980, p. 28
} 
"Teatrino Nasi”), visto que os grupos tinham “(...) um circuito fechado com enorme intercâmbio e cooperação entre eles" ${ }^{22}$ para se encontrar locais de apresentação.

As reuniões festivas, quando os grupos se apresentavam fora de seus locais usuais, se realizavam “(...) em pontos pitorescos dos arredores da cidade, como Cantareira, Ipiranga, Vila Mariana, Penha e Santo Amaro. Eram festas campestres muito alegres e fraternais, em que cada família levava o seu farnel (saco de comida) e terminavam sempre por uma palestra educativa"23. As festas, com entrada paga pelo público presente - um ou dois contos de réis -, comportavam apresentações e bailes como de hábito, além de venda de rifas para conscientizar o público da necessidade de manutenção das atividades do grupo.

Porém, “(...) se considerarmos o pequeno rendimento habitual dessas festas, inclusive em proporção às necessidades dos grupos e locais (onde se apresentavam), não é difícil concluir sobre a solidariedade simbólica desses espetáculos (sendo) comum a proximidade ou quase coincidência entre a receita e a despesa"24. Uma das maiores despesas dos espetáculos era com os músicos, que muitas vezes tendo sido já formados por escolas como o Conservatório Dramático e Musical não queriam ser tratados como amadores, mas como profissionais, exigindo assim pagamentos que muitas vezes eram equivalentes ou até mesmo excediam o aluguel do salão da festa ${ }^{25}$.

Nesse contexto, surgiu aquela que é a figura mais proeminente dos filodramáticos paulistanos a ponto de passar por momentos diversos da formação teatral da cidade e do país, sempre deixando sua marca indefectível em todos eles ao quebrar barreiras de modo pioneiro para os artistas imigrantes: a atriz Itália Fausta. Faustina Polloni, ou simplesmente Itália Fausta (ou ainda Polônia Faustina, como chegou a ser chamada), foi uma ítalo-brasileira que iniciou seu trabalho como atriz com as sociedades filodramáticas, ainda que em contato com grandes companhias desde o início de sua formação, tendo sido chamada para compor elenco em performances italianas que visitavam a cidade de São Paulo.

\footnotetext{
${ }^{22}$ SILVEIRA, 1976a, p. 64

${ }^{23}$ DIAS, Everardo. História das lutas sociais no Brasil, 1977 - 2a ed., p. 42, apud POMPEU DE TOLEDO, 2015, p. 143

${ }^{24}$ VARGAS; ALVES DE LIMA, 1980, p. 33

${ }^{25}$ Idem, p. 42
} 


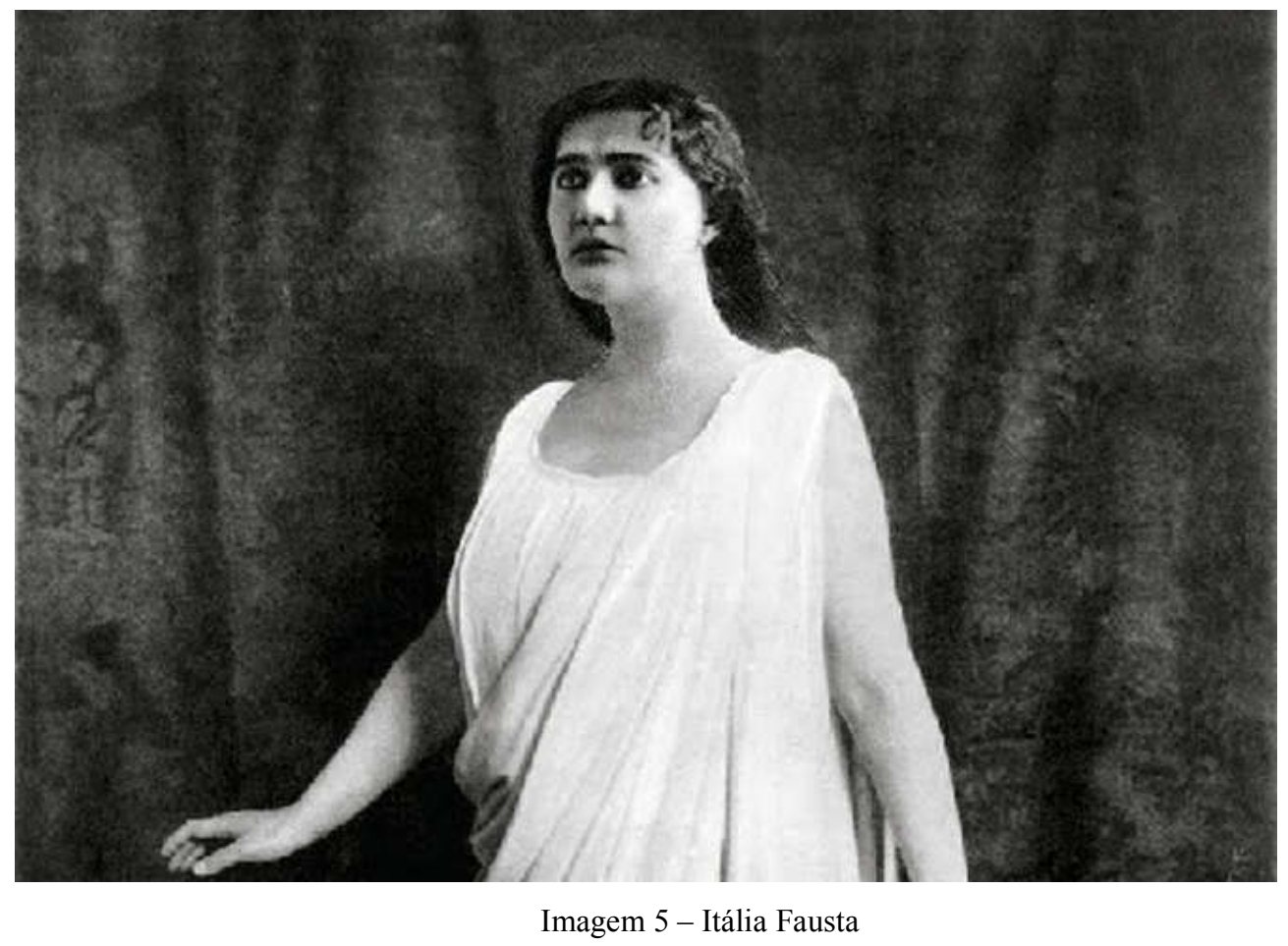

Seu nome em todas as suas variantes foi encontrado em ao menos três oportunidades como primeiro registro de sua atuação nos palcos: nos Clubs Paulo Giacometti em 1898 e Dante Alighieri em 1900 - este último ligado ao tradicional colégio dos Jardins -, ou ainda como participante de temporada da atriz italiana Clara Della Guardia em 1899, sempre considerando que ela era ainda muito jovem em todos esses papéis, com cerca de doze anos de idade. Apesar das divergências quanto à data de sua estreia, não se pode deixar de constatar que o grande feito de Itália Fausta aos filodramáticos tenha sido o de sua inserção do teatro institucionalizado, "configurandose em materialização existencial de muitos dos sonhos e propósitos" ${ }^{26}$ dos imigrantes. Ao levar seu nome a se tornar o primeiro exemplo de diva brasileira - ela que tinha Eleonora Duse como grande inspiração - fez com que as portas de outros espaços além dos teatrinhos próprios desses grupos fossem abertas aos imigrantes.

Um marco dessa mudança de patamar dos filodramáticos não se deu no palco mas em um dos espaços de convívio social da elite paulistana de então, ao se convocar grupos de imigrantes para recepcionarem Clara Della Guardia no Clube Espéria em mais uma de suas visitas a São Paulo. Isso mostra como a ascensão dos grupos - e de Itália Fausta em particular - pesou para que os artistas italianos contemporâneos

\footnotetext{
${ }^{26}$ SILVEIRA, 1976a, p. 69
} 
passassem a vir mais frequentemente a São Paulo para se apresentar. Esse movimento fazia com que os integrantes dos grupos filodramáticos “(...) discutissem (técnicas para) interpretações, formassem comporações críticas, e os dispusesse a cada vez mais emular (seus modelos) e progredir" (SILVEIRA, 1976a, p. 78/9).

Nesse sentido, pensar na atuação de Fausta de forma individualizada, e em sua evolução no teatro brasileiro como uma perda do caráter coletivo do movimento filodramático como um todo, não é condizente com o que aconteceu. A ascensão de Fausta provocou grande movimentação na organização dos grupos, que buscavam refletir isso no primeiro Festival de Amadores Italianos do Brasil em 1905, festival esse com sérios problemas de organização ${ }^{27}$. Alijada dessas questões, Fausta se tornou a primeira artista desses grupos com um contrato oficial, para uma turnê da Companhia Dramática Portuguesa em 1906.

A partir desse momento, houve a transição definitiva de Itália Fausta para ganhar os teatros nacionais. Ao assimilar a fala lusitana então exigida nos palcos do teatro institucionalizado para se interpretar personagens em português à moda da declamação padrão da Commedie Française que ela já ostentava, e que lhe fazia ser a mais habilitada para personagens trágicos por não havia formação do gênero no país, Fausta alargava o horizonte dos que nela se inspiravam e que, mesmo que tivessem alguma formação anterior, tinham como "(...) tendência estética se polarizar "all'improviso" (quanto á) elaboração vocal, elegância e composição lógica” (SILVEIRA, 1976a, p. 34). Os grupos amadores passaram a atuar em dois modos distintos: ou eles também assimiliavam uma maior institucionalização de sua atuação na sociedade, se colocando junto a espaços oficiais e reconhecidos pelas autoridades constituídas; ou buscavam radicalizar mais inserção em clubes de natureza social em contato com sua comunidade.

Entre os que escolheram expandir seus campos de atuação e institucionalizar suas práticas, Itália Fausta esteve entre aqueles que ganharam muito com essa aproximação. A família Polloni fez isso ao comprar e reformar o Salão Excelsior e transformá-lo no Salão Itália Fausta em junho de 1906, para então colocá-lo à disposição de grupos amadoress e de outras atividades promovidas por Fausta. Arthur Azevedo, um dos grandes dramaturgos da Corte carioca no Segundo Reinado, também a

${ }^{27}$ Há incertezas quanto à realização do festival, que mudou várias vezes de data e local entre setembro e novembro de 1905. Cf. em: SILVEIRA, 1976a, p. 85-6 
escudou como “(...) o talento mais digno de ser desenvolvido nestes últimos tempos”,28 ao vê-la se apresentar no Rio de Janeiro. Ele conseguiu para ela apoio da imprensa e do público local, assim fortalecendo sua campanha pela defesa do talento nacional que levou à inauguração do Teatro Municipal do Rio de Janeiro, finalizado em 1909.

Essa defesa do talento nacional seria acompanhada pela fundação em 1908 da Escola Dramática de Coelho Neto, e em 1909 de uma Companhia Dramática Nacional (CDN) em homenagem a Arthur Azevedo, recém-falecido quando da inauguração do Municipal do Rio de Janeiro. Paralelo a isso, ainda em 1908, houve a abertura do primeiro centro de arte dramática para formação de candidatos a integrarem grupos filodramáticos em São Paulo, mantida na Ladeira Santa Ifigênia por pagamentos de anuidades que permitiam frequência aos clubes dos grupos colegados ao centro de formação.

Eram várias as possibilidades de restituição do dinheiro investido, desde a promoção de “(...) festa artística onde obteriam restituição da anuidade, bilhetesconvites que podiam ser vendidos, e prêmios segundo méritos" (SILVEIRA, 1976a, p. 99). Com tantas modalidades de retorno dos pagamentos, é de se pensar o que bancava a manutenção da escola, e se ela cumpria seu papel na reposição de artistas para os grupos. Entre os que preferiram manter o foco de sua ação nos clubes, com uma atuação mais politizada e ligada às comunidades, o protagonismo foi tomado pelos integrantes do movimento do teatro operário e anarquista.

O trabalho desses grupos se intensificou na promoção de peças de teatro junto às festas itinerantes, dando ênfase às datas de feriados no país, como o Dia do Trabalhador onde a peça "Primo Maggio", de Pietro Gori, se tornou marco da ação do teatro operário, sendo repetida todo ano por vários grupos desde sua primeira sessão em São Paulo no Teatrinho do Cambuci, em 30 de abril de 1902. ${ }^{29}$ Assim, grupos com a proposta de se manterem amadores dentro desse contexto tinham longevidade variável, podendo entrar numa categoria de "grupos relâmpago", ou seja, de sociedades que não conseguiam se manter com suas propostas de apresentação e acabavam sendo incorporados por outros grupos ou simplesmente sumiam; ou mesmo grupos que tendo radicalizado suas propostas, conseguiam encontrar um nicho de subsistência que lhes

\footnotetext{
${ }^{28}$ apud SILVEIRA, Op. Cit., p. 88

${ }^{29}$ Cf. em FARIA, 2012, vol. 1, p. 362; e HIPÓLIDE, 2012, p. 142
} 
mantinha por um longo período. Entre os que resistiram a mudanças, destacam-se os grupos Muse Italiche e Dopolavoro, que inclusive mantiveram encenações em língua italiana até por volta de $1950^{30}$. Entre os grupos "relâmpago", foram contados quinze que tiveram atuação fugaz em São Paulo entre 1900 e 1920 a partir de registros da época. $^{31}$

Um bom exemplo da atuação desses grupos nas festas se deu em um festival em 1907, a "Commemorazione Goldoni”, que se tornou um marco filodramático ao ser capitaneado pelo Circolo Amore all'Arte, considerado um dos grupos melhor estabelecidos e um dos mais longevos na primeira metade do século XX após a ascensão de Fausta. O Amore all'Arte, com sede no Brás desde 1901, pode ser considerado o grupo que com seu repertório, escolhido entre artistas italianos que bebiam da fonte do Ginásio Dramático de Paris, começou a fazer a ponte entre o teatro realista feito na segunda metade do século XIX - e que não estava nos teatros da Corte de então, apesar de apreciado por ela - com o que viria a ser o discurso "moderno" no teatro e na arte que logo iria eclodir na cidade.

Eles preferiam se manter à margem do reconhecimento oficial. Porém, contrariando a atuação dos grupos que se esvaíam em uma ou duas temporadas sem grande comprometimento ou mesmo reconhecimento da sociedade, tiveram grande resposta crítica e retorno quanto à sua importância no cenário em evento de comemoração dos seus 23 anos de atividade, em dezembro de 1923, quando o jornalista Francisco Pettinati usou do intervalo da apresentação do grupo para elogiar sua atuação e dos filodrammáticos na história teatral paulistana, ainda que "em tom claramente elegíaco (onde se sente) que o orador descreve algo que já terminou ou que está prestes a expirar (nesse movimento) antes apaixonado e sumarento de substância"32.

O diagnóstico de Pettinati acaba se tornando preciso no sentido de que, por mais que os filodrammáticos e grupos que a eles orbitavam tivessem tentado novos caminhos para sua expressão a partir da ascensão de Itália Fausta ao circuito oficial do teatro paulistano e brasileiro, eles seguiriam atuando principalmente em suas comunidades e em lugares mais distantes dentro da cidade por toda a primeira metade do século XX.

\footnotetext{
${ }^{30}$ FARIA, 2012, vol. 1, p. 361

${ }^{31}$ HIPÓLIDE, 2012, p. 37-45

${ }^{32}$ SILVEIRA, 1976a, p. 199
} 
Ainda que houvesse esse movimento de expansão da atuação para além de sua comunidade, chegou um momento em que não houve mais como lutar contra a maré moderna. Assim, sem mais tantos arroubos criativos nos seus modos de trabalho e sem mais tanta vontade de irem além de seus locais de atuação, esse tipo de organização se manteve ainda por um longo período ainda que cada vez mais retornando à marginalidade de onde se originou, voltando a olhar para dentro de si mesmo. Desse modo, este movimento original e fantástico do teatro brasileiro acabaria por manter tamanha influência no modo de fazer teatro que terminou por irromper-se em outros momentos marcantes da vida cultural paulistana.

\subsection{Estrutura Estatal Moderna e Influência dos Grupos Estudantis}

Com o teatro oficial seguindo seu modelo de abrigar companhias lideradas por um artista de proeminência e uma política de expansão de espaços algo desordenada, a concorrência entre iniciativas públicas e privadas no meio teatral passou a se acirrar a partir da década de 1910. Essa aparente concorrência resvalava em certa promiscuidade nas relações entre tais entes, onde o interesse imediato de ambos os lados na promoção de eventos e oportunidades de mostrar serviço na ocupação dos teatros acabava muitas vezes prevalecendo sobre planejamentos a longo prazo mais elaborados e iniciativas de formação para quem buscava trilhar os caminhos então abertos para profissionalização, em cursos dramáticos ou no trabalho com as companhias oficiais.

Isso se deu nitidamente naquele que foi considerado o primeiro incentivo direto do poder público a uma iniciativa teatral em São Paulo, desconsiderando as permissões para obras e reformas ou a construção de prédios teatrais. O empresário Eduardo Vitorino veio a São Paulo em 1912 interessado em um projeto de concessão de auxílio de vinte contos de réis à Companhia Dramática Nacional (CDN), que apesar de sediada no Rio de Janeiro viria fazer apresentações em São Paulo em 1913. A CDN viria com a condição de encenar em seu programa duas peças de dramaturgos paulistas dentro da programação de cinco meses no Teatro Municipal. Por fim, a prefeitura permitiu as apresentações dando à companhia “(...) isenção de pagamento do aluguel, de impostos e despesas com iluminação e do pessoal encarregado do serviço interno do teatro"33, além

\footnotetext{
${ }^{33}$ MAGALDI; VARGAS, 2001, p. 57
} 
de lhes conceder o auxílio financeiro pretendido. A única contrapartida exigida à companhia foi o pagamento dos cenários para as apresentações das peças paulistas vencedoras do concurso promovido pela prefeitura - tais cenários não deviam custar menos de dez contos de réis.

Esse movimento político de sobreposição entre interesse público e privado era o desdobramento de outras situações experimentadas naquele período, nas inaugurações do Teatro Colombo no Brás, no Largo da Concórdia, em fevereiro de 1908, e do novo Teatro São José no Anhangabaú, em dezembro de 1909 - antes, portanto, do Teatro Municipal abrir em $1912^{34}$. O Teatro Colombo foi construído sobre um velho mercado embargado pela Prefeitura em 1906, e poucos meses depois ele foi arrendado por autorização do prefeito a Pedro França Pinto, que o reformou com a ambição de fazer deste o maior teatro da cidade na época. Com um empréstimo de cem mil contos de réis dado à Companhia Antarctica Paulista - para obra de cento e conquenta mil, o que fazia da empresa a arrendatária de fato do lugar -, o prazo do arrendamento da prefeitura de trinta anos foi ampliado por mais dez, até 1948. Porém, ele só foi desapropriado pelo Departamento de Cultura em 1966 após um incêndio, segundo Miroel Silveira, “(...) providencial como todos os que convém a quem tem outros planos a um imóvel., 35

E o novo Teatro São José era enorme, comportava mais de três mil pessoas maior que o Colombo, portanto. Tinha ótima localização ocupando todo o quarteirão, aproveitando o declive em direção ao Vale do Anhangabaú que serviu à construção do Viaduto do Chá, o que lhe permitiu uma ótima ocupação do espaço para o palco e boa visão à plateia. Inaugurado em dezembro de 1909, teve então uma boa recepção do público e de companhias estrangeiras visitantes, ostentando até mesmo publicidade em sua fachada arrendada pelo então proprietário do prédio, o empresário e banqueiro Paulo de Assumpção. Contudo, a inauguração do Municipal logo em frente relegou o São José a um período de terrível ostracismo, e o proprietário vendeu o prédio para a Light Co., em negociações iniciadas em 1920 e só concluídas em 1923.

Sendo assim, os teatros de São Paulo passaram a procurar por outras formas de atração do público e de receita para além das peças de teatro. O primeiro passo foi a criação de espaços de convivência como "botequins" ou "buffets" como atração para

\footnotetext{
${ }^{34}$ Cf. em POMPEU DE TOLEDO, 2015, p. 64
}

${ }^{35}$ SILVEIRA, 1976a, p. 98-9 
pessoas que gostariam de praticar a sociabilidade no espaço interno dos teatros. Porém, em teatros como o São José eles somente funcionavam em momentos prévios às apresentações. Nesse sentido, o Teatro Municipal tinha mais um ganho na concorrência contra eles, pois o seu Bar do Municipal ficava aberto "por longos períodos" mesmo quando não havia espetáculo (POMPEU DE TOLEDO, 2015, p. 125), num movimento intenso que ofuscava a sensação de perda de qualidade.

Alem disso, entre os anos 1920 e 1930 os teatros passaram a viver uma grande crise com a expansão dos cinematógrafos, que dividiam o mesmo espaço de muitos teatros, não apenas pelas grandes capacidades de público desses lugares mas também pelo próprio apelo de suas atrações. Nesse tempo, a impressão geral era de que “(...) o cinema (parecia) desenvolver-se em 300 quilômetros por hora (enquanto) o teatro vai em velocidade mínima de 30 por hora, com paradas forçadas nos semáforos. ${ }^{\text {36 }}$ Parecia naquele momento haver maior interesse pelas imagens em movimento do cinema do que para a arte teatral, que estava concentrada em sua maioria em peças de revista, operetas e números farsescos em um nítido refluxo do teatro dramático.

O público mais popular que enchia salas como o Teatro Colombo e o novo São José para assistir a teatro se interessava por gêneros como o sainete, uma variante do teatro de revista vinda da Argentina, por trazer algo mais próximo de uma “(...) apresentação da realidade como ela era, pois os personagens mostravam verdades que podiam ser facilmente compreendidas" ${ }^{\$ 7}$ por esse público. Essas personagens deviam mostrar uma oposição bastante clara entre mocinhos (protagonistas) e vilões (antagonistas). Com uma ambientação semelhante á dos grupos filodramáticos mas apresentando histórias centradas nas diferenças entre os diversos grupos que ocupavam a cidade (portugueses, espanhóis, árabes, caipiras e cariocas), o público se divertia muito em peças como "O Castagnaro da Festa", de Oduvaldo Vianna, em 1928. Esta peça chegou a ter anúncio para procura de atores interessados nos papéis de imigrantes.

Um tanto alheio a esses movimentos, a alta sociedade paulistana entrava em discussões quanto à conciliação do seu gosto pela cultura europeia, francesa em especial, com certos sentimentos nacionalistas de valorização da arte local que

\footnotetext{
${ }^{36}$ Fala retirada de conferência do encenador italiano Antonio Bragaglia junto ao grupo filodramático Muse Italiche em São Paulo em 1930; in: FARIA, 2012, vol. 1, p. 361

${ }^{37}$ VENEZIANO, 2006, p. 30-2
} 
começavam a aflorar no debate público. Essa cisão se deu também no recém aberto Teatro Boa Vista, chamado pela imprensa tradicional de "centro chic"38 quando inaugurado em 1916 entre as ruas Boa Vista e 25 de Março com seu grande salão para uma plateia de 350 lugares, de tamanho menor que os inaugurados até então e claramente uma resposta a estes quanto à busca por uma seleção maior em sua audiência, algo que seria tomado como padrão mais adiante ${ }^{39}$.

Pouco depois, houve o lançamento de um novo e de certa forma inédito esforço conjunto em prol de uma formação teatral de padrão profissional mais homogêneo: a Companhia Dramática de São Paulo, encampada por três associações de artistas, de diferentes origens e especificações: a Sociedade de Cultura Artística; a Sociedade Brasileira dos Autores Teatrais (SBAT), órgão para registro das obras artísticas; e o Conservatório Dramático e Musical. Com nomes como os de Itália Fausta nos palcos e uma nítida separação entre a direção artística, liderada por Gomes Cardim (do Conservatório), e o conselho administrativo ${ }^{40}$ com integrantes de todas as sociedades envolvidas, havia uma expectiativa de que todo o possível tinha sido feito para garantir o sucesso da empreitada.

As frisas do teatro eram arrendadas aos alunos do Liceu de Artes e Ofícios nas sessões de domingo, o que contemplava o centro formativo oficial. Esta escola que não estava na composição original da sociedade do Teatro Boa Vista possibilitou a formação da Companhia, onde ela também se apresentava, ao mesmo tempo que tal ação não comprometia o escalonamento de preços dos setores para o público geral - doze contos de réis para os camarotes, dois para as cadeiras e um para as frisas.

Cabe aqui fazer considerações sobre as associações que se juntaram para fazerem com que se essa iniciativa se concretizasse. A Sociedade de Cultura Artística, fundada em 1912, foi o primeiro exemplo de entidade ligada à elite paulistana com a

\footnotetext{
${ }^{38}$ Jornal O Estado de S. Paulo, novembro de 1916, in: MAGALDI; VARGAS, 2001, p. 82

${ }^{39}$ Segundo o jornal $O$ Estado de S. Paulo no dia 11 de agosto de 1926, o espaço passou por ampla reforma e foi inaugurado plenamente nessa data, passando a contar com 982 lugares. Cf. em: BATISTA, Liz. Era uma vez em SP: teatro Boa Vista. In: O Estado de S. Paulo, 10 de abril de 2015, Disponível em: <http://acervo.estadao.com.br/noticias/acervo,era-uma-vez-em-sp-teatro-boa-vista,10972,0.htm> Acessado em 18 de julho de 2019

${ }^{40}$ Faziam parte do primerio conselho administrativo da Companhia Dramática de São Paulo os seguintes nomes: Carlos de Campos, José Paulino Nogueira Filho, Gofredo da Silva Teles, Luis Fonseca, Nestor Rangel Pestana e Ricardo Figueiredo, in:MAGALDI; VARGAS, Op. Cit., p. 87
} 
intenção de investirem em atividades culturais. Seus fundadores foram Vicente de Carvalho, Arnaldo Vieira de Carvalho, Nestor Rangel Pestana, Frederico Vergueiro Steidel, Roberto dos Santos Moreira e Júlio Mesquita (então dono do jornal O Estado de S. Paulo). Com a Sociedade tendo concentrado seus esforços na promoção de eventos de literatura e música desde sua fundação, a Companhia Dramática foi seu primeiro investimento na área teatral até a construção de seu teatro próprio, projeto este pretendido pelos associados por conflitos de agenda para seus eventos em outros teatros.

Já a SBAT foi fundada em 1917 a partir da Sociedade Brasileira de Autores, que tinha como associados integrantes do meio artístico preocupados com a gestão dos direitos sobre o conteúdo artístico nacional, sobretudo dramaturgos, escritores e compositores. Tendo seu ramo teatral aberto no Rio de Janeiro e reconhecida oficialmente pelo governo federal pelo Decreto N.4092 em 04 de agosto de 1920 como de utilidade pública, passou a receber contribuições de seus associados que delegavam à entidade representação dos artistas perante litígios com entes governamentais e empresas teatrais. A promoção de atividades promotoras dos artistas nacionais nos grandes centros também fazia parte de suas atribuições.

Apesar de a Companhia ter realizado em 1917 a consagradora apresentação da temporada de Itália Fausta em "A Ré Misteriosa”, de Bisson, a imprensa ataca a direção de Gomes Cardim, e por extensão a iniciativa do novo empreendimento, como "uma insuportável moléstia de, por preguiça ou ignorância, copiarmos covardemente o que é estrangeiro" ${ }^{\text {, }}$, reverberando uma visão que começava a se tornar corrente no debate público de que a arte paulistana deveria buscar outro modelo para sua atuação. Com essa reação refratária por parte da crítica, a experiência da companhia oficial paulistana não foi muito longe e Itália Fausta foi reincorporada à Companhia Dramática Nacional.

A reincorporação de Fausta à CDN após essa tentativa de fortalecimento do teatro paulistano ensejou novo incentivo teatral público para uma iniciativa de fora da cidade. Em fevereiro de 1921 houve uma discussão na Câmara por um auxílio à CDN onde foram concedidos auxílio de dez contos de réis - metade do subvencionado a eles em 1912 - e subvenção quanto às despesas de luz e pessoal. As justificativas, do então vereador Luciano Gualberto, falavam da necessidade do auxílio pelo fato de “(...) nela

\footnotetext{
${ }^{41}$ Jornal O Estado de S. Paulo, 17 de março de 1917, in: MAGALDI; VARGAS, 2001, p. 87
} 
fazer parte a festejada atriz paulista Itália Fausta (e que) o cinematógrafo está absorvendo tudo"42 na atenção do público, reproduzindo o receio geral de que a arte teatral sucumbisse ao cinema.

No âmbito privado, esse receio da invasão do cinema sobre o teatro motivou a Sociedade de Cultura Artística a juntar "jóias" para auxiliar na compra do terreno da futura sede, assim como também eram arrecadados fundos junto aos frequentadores de seus eventos. Em 1919, a Sociedade conseguiu a compra do terreno da rua Nestor Pestana, onde ficava o antigo Velódromo da cidade. O local era palco para as disputas esportivas de ciclismo e futebol desde o início do século XX, derrubado pouco antes por não comportar mais a crescente popularidade do futebol. $\mathrm{O}$ ambicioso projeto da nova sede traria um novo centro cultural para a cidade, com salão principal para duas mil pessoas e áreas para exposições de pinturas, bibliotecas e restaurantes. No entanto, com o passar dos anos a capacidade econômica da Sociedade não lhes permitiu prosseguir com a construção da sede. Enquanto isso, companhias profissionais do Rio de Janeiro seguiam ditando o que seria o teatro considerado de padrão mais elevado em São Paulo.

A companhia de Lucília Pires e Leopoldo Fróes, fundada em 1915 - que praticamente ocupou o Teatro Boa Vista para si em seus primeiros momentos na cidade de São Paulo -, apesar de também apresentar repertório francês, adicionou um elemento à discussão da brasilidade na arte teatral ao montar a peça "Flores de Sombra", de Claudio de Sousa. Porém, não haveria como não reparar nos problemas de produção dessa “(...) ação absolutamente paulista (passada) em uma fazenda (que por) demora dos estudos do cenógrafono interior" ${ }^{\circ 3}$, fizeram com que o cenário não chegasse a tempo para a data programada da estreia, mostrando o quanto certo teatro brasileiro estava distante de uma representação de seu cotidiano, ao passo que insistia em reprodução de naturalismos de forma pouco técnica.

A companhia de Procópio Ferreira, outro modelo de companhia profissional surgido em 1924, parecia ter um outro trato com essas questões. Procópio era nesse momento um ator já consagrado em sua técnica de palco que lhe permitia passar ao largo das discussões nacionalistas, ao mesmo tempo que encarnava aos olhos do público e da crítica uma legítima expressão brasileira. Na apresentação do balanço de sua

\footnotetext{
${ }^{42}$ MAGALDI; VARGAS, 2001, p. 95

${ }^{43}$ Ibid., p. 83
} 
temporada inicial de oito meses com a companhia em São Paulo, são enumeradas três peças de autores argentinos - algo praticamente inédito até então no circuito paulistano - sem que se acusem o ator e sua companhia de não trabalharem pelo conteúdo nacional, apesar de efetivamente “(...) no repertório de vinte e seis peças (da companhia), apenas quatro serem brasileiras" (MAGALDI; VARGAS, 2001, p. 101).

Porém, seu planejamento mais meticuloso e pensado a longo prazo colocava quaisquer possíveis críticas a seu trabalho no palco em segundo plano. Na questão cenográfica, sabia alinhar a percepção de amplitude visual dada pelo cinema para construir junto com artistas plásticos a ambientação que tinha como objetivo deslumbrar a plateia e prender sua atenção, sem que fossem invocadas paisagens naturalistas ou mesmo realistas em demasia. Apenas a maneira diferenciada com que se preocupou com a ambientação de suas obras já o colocava à frente de muitos dos seus contemporâneos, culminando na montagem em 1932 de "Deus lhe Pague", de Joracy Camargo, sua peça mais aclamada e reprisada a partir de então.

Procópio certamente foi um dos que se beneficiou por uma nova resolução criada pelo então deputado Getúlio Vargas que em 1928 elaborou um projeto junto à SBAT que se transformou no Decreto-Lei N. 5492 para “(...) organizar a profissão de artista e estabelecer uma série de medidas protetivas para a categoria" (CAMARGO, 2010, p. 2). Essas medidas ajudaram a dar um pouco mais de segurança e planejamento para a ação das companhias existentes; contribuiram para a criação de outras, como a de Abgail Maia-Raul Roulien em 1928 e a de Dulcina de Moraes-Odilon Azevedo em 1935; e fortaleceram as associações de classe então criadas e que buscavam reunir artistas para causas em comum. Já como Presidente, em 1932, essa medida de Vargas foi realçada pela criação de uma comissão feita para elaborar um estatuto padrão para profissionais de teatro.

Naquele momento, em meio à discussão sobre a crescente profissionalização da produção local, associações eram respaldadas pelo apoio de nomes fortes no cenário teatral: nomes como Procópio Ferreira, Itália Fausta, Luiz Iglésias e Alda Garrido eram ligados à Casa dos Artistas ${ }^{44}$; e Oduvaldo Vianna, Abadie Faria Rosa, Armando

\footnotetext{
${ }^{44}$ A Casa dos Artistas no Rio de Janeiro foi fundada por Leopoldo Fróes em 1918 (morto em 1932) nos moldes da Maison de Repos des Artistes Français, de Paris, como uma associação ativa até hoje conhecida como local de amparo para artistas retirados dos palcos, construída com fundos arrecadados
} 
Gonzaga e Gastão Tojeiro à SBAT. Em meio a essa busca por maior institucionalização dos artistas do teatro, um novo movimento conseguiu colocar uma nova perspectiva sobre a arte brasileira sob olhar da elite cultural.

A Semana de Arte Moderna, realizada em três dias de fevereiro de 1922, se deu primeriamente pela figura daquele que seria o grande mecenas da Semana, o homem de negócios Paulo Prado. Ele, com suas pretensões intelectuais e uma grande inserção no círculo artístico, foi o grande articulador para sua realização ao viabilizar a vinda de artistas de fora da cidade (como Heitor Villa-Lobos, na época no Rio de Janeiro) e para que o evento se realizasse no Teatro Municipal da cidade, lutando também para que a recepção entre o público selecionado pudesse ser a melhor possível para um momento que se colocava como revolucionário esteticamente.

Seu posicionamento interessado no âmago da cultura brasileira em seus escritos fez Gilberto Freyre descrevê-lo como "um dos casos mais curiosos de Dr. Jekyll e Mr. Hyde que já houve no Brasil, (ao ponto) das gerações futuras se espantarem ao ver um nome associado ao mesmo tempo ao modernismo e ao Departamento Nacional do Café." ${ }^{45}$, ao mesmo tempo que bradava para que o país pudesse, em suas palavras, “(...) despertar para a democracia e a modernidade econômica”. Apesar dessas aparentes contradições típicas da inserção problemática do país na lógica capitalista liberal, com homens do capital seguindo lógicas exploradoras enquanto pensavam no futuro do país, não há como negar o papel fundamental de Prado para superar os grandes desafios de efetivação da Semana, para que os artistas pensassem apenas em suas apresentações:

Para arcar com as despesas foi lançada uma lista de subscrições, encabeçada por Paulo Prado e integrada por mais alguns Prado, por Penteado e outros sobrenomes ilustres. $O$ aluguel do Municipal custou oitocentos e quarenta e sete mil réis. O aluguel e as despesas de hospedagem do grupo carioca [...] seriam cobertos pelo dinheiro arrecadado. Estava consolidado o rumo do modernismo paulista - um movimento "revolucionário" respaldado por grandes nomes da elite social e econômica. ${ }^{46}$

pela associação e subvenção federal e municioal. Cf. em: CASA DOS ARTISTAS, Mapa dos Artistas: Leopoldo Fróes, Disponível em: <https://culturaniteroi.com.br/blog/?id=2451\&equ=mapadeartistas> Acessado em 19 de Julho de 2019

${ }^{45}$ FREITAS, Guilherme. "Paulo Prado foi elo entre negócios e artistas de São Paulo em 1922", in: Jornal 0

Globo. Disponível em: <https://oglobo.globo.com/cultura/paulo-prado-foi-elo-entre-negocios-artistasde-sao-paulo-em-1922-3874863> Acessado em 21 de Julho de 2019

${ }^{46}$ POMPEU DE TOLEDO, 2015, p. 185 
Apesar da Semana trazer pouca expressão teatral, a valorização das artes advinda desse movimento e o surgimento concreto de um debate artístico genuíno traziam o que para muitos simbolizava “(...) um fermento de modernidade (...), o coroamento dos esforços de desenvolvimento e construção da nação (na) organização de uma sociedade aberta e democrática" (ARRUDA, 2001, p. 18). Uma contribuição bastante importante da Semana de 22 foi a reivindicação de uma expressão brasileira para as artes, e isso também aconteceu no teatro, pois foi com ela que “(...) se tombou a Bastilha do lusitanismo (na dicção dos atores) para que se iniciasse o reconhecimento da fala brasileira como (expressão) legítima" (SILVEIRA, 1976a, p. 89) ${ }^{47}$.

O desenvolvimento cada vez maior de produções teatrais com textos nacionaism implicou em um efeito colateral que estava adormecido desde o fim do Segundo Reinado e que voltou com bastante força a partir dos anos 1920: o controle estatal sobre os conteúdos teatrais, que já podia ser chamado de censura a partir do nome dado pelos próprios aparelhos de Estado responsáveis por este controle ${ }^{48}$. O primeiro decreto de censura prévia da República é de 9 de dezembro de 1920, e foi editado visando o controle de espetáculos teatrais e películas cinematográficas. Em 1928, o Regulamento Policial paulista reforçava junto ao teatro no Estado de São Paulo a ação da censura dada pelo decreto federal, que era especialmente dura com o teatro de revista (VELOSO-PAMPOLHA, 2007, p. 12), por este gênero trazer em seu caráter satírico uma crítica mais direta aos acontecimentos cotidianos, e um trabalho de improvisação constante e aparentemente incontrolável a partir dessas situações.

Quanto ao controle da censura, uma montagem que certamente sofreu todo tipo de retaliação estatal foi “Andaime”, de Paulo Torres, encampada pelo ator Jaime Costa como início do que denominou "teatro social”, a partir desta que seria “(...) a primeira peça feita sob orientação do moderníssimo teatro ideológico da Rússia, Alemanha e França." ${ }^{49} \mathrm{O}$ processo de censura contra a peça recomendava seu veto total em 1932 a

${ }^{47}$ Cf. na p.37
${ }^{48}$ Para maiores referências sobre o conceito de censura na modernidade, Cf. em: FIGARO, Roseli.
Censura e resistência: o teatro de grupos amadores na cidade de São Paulo [artigo online], in: 452-F.
Revista eletrónica de teoria da literatura e literatura comparada, n. 10, p. 16-34; e GARCIA, Miliandre,
A censura de costumes no Brasil: Da institucionalização da censura teatral no século XIX à extinção da
censura na Constituição de 1988. Rio de Janeiro, Fundação Biblioteca Nacional, 2009
${ }^{49}$ Renato Vianna se enquadraria como precursor dessa tendência, com o grupo experimental Sociedade
dos Companheiros da Quimera fundado com o maestro Heitor Villa-Lobos e o poeta Ronald de Carvalho.
Porém seu texto nos anos 1920 foi visto pela crítica como “(...) livresco e pomposo, incapaz de tornar 
partir do que considerou “(...) um arranjo sem técnica ou merecimento literário e propaganda subversiva" ${ }^{, 50}$.Mas a produção prometida por Jaime Costa trazia algo completamente diferente de uma falta de técnica, ao se escudar em “(...) cenários desenhados por artistas audaciosos, (...) uma fábrica em movimento com todos seus maquinismos trabalhando, salão-bar de um grande hotel, andaimes de um arranha-céu em construção," ${ }^{, 51}$ pressupondo uma peça a ser vista em múltiplos níveis no que seria uma quebra quase sem paradigmas com o padrão encenado no país até então.

Ainda que a intenção e a execução final da produção no sótão do Teatro São Paulo tenham tido resultados diversos, como atesta o encenador da peça Livio Abramo $^{52}$, o que certamente fez com que ela caísse em desgraça foi a maneira como Jaime Costa teria edulcorado o texto para cair no gosto dos órgãos censores após o veto inicial. Essa modificação teria ocorrido em visita dos censores aos ensaios (que Abramo admite não ter acompanhado) tal como solicitado pelo produtor Raul Soares no seu recurso alegando, além da contestação ao veto do conteúdo, o fato de já ter gasto dinheiro na produção. Desse modo, a peça não quebrou os paradigmas como queria, mas permaneceu como um caso inequívoco e marcante de interferência estatal em uma produção artística na modernidade.

O recrudescimento sobre o teatro produzido naquele momento começava então a dar sinais de ir além dos gêneros mais populares, se instalando de maneiras mais sofisticadas e menos aparentes. Os obstáculos de montagem de peças como "Andaime" - pressão sobre e a partir de produtores ou patrocinadores, visitas de censores aos ensaios, autocensura e dificuldades de angariar recursos ou de ter melhor divulgação foram sentidos por produções de diferentes matizes, chegando ao ponto de muitas vezes configurarem verdadeiros casos de polícia quando porventura ultrapassavam esses obstáculos e conseguiam entrar em cartaz, com interrupções prematuras de temporadas e intervenções policiais nos próprios locais de apresentação. Sobre esse contexto, Giuliana Simões (2009) descreve o que se passou com muitos dos que encararam problemas com as autoridades para fazer teatro naquele período:

concreto o cenário de uma boa encenação" (SILVEIRA, 1976a, p. 289). Cf. sobre sua obra em: MILARÉ, Sebastião. Batalha da quimera, Brasília: FUNARTE, 2009

${ }^{50}$ LAET, 2007, p. 93

${ }^{51}$ In: MAGALDI; VARGAS, 2001 ,p. 127

${ }^{52}$ Idem, p. 128 
A impossibilidade de montagem de peças no periodo destacado (anos 1920 e 1930) - ou pela censura política que proibiu suas produções, ou ainda porque não foram bem recebidas por empresários, que não viam nelas boas oportunidades de lucro [...]; ou a falta de público e mesmo péssimas críticas que acompanharam espetáculos teatrais com propostas inovadoras, são fatos representativos dessa recepção (como ocorreu à) encenação de "A última encarnação de Fausto", do grupo de Renato Vianna, que ficou somente três dias em cartaz; a montagem de Benjamin Lima, "O homem que marcha", que esteve em cartaz em São Paulo em 1925, [...] e finalmente a não encenação do texto dramático "O rei da vela", de Oswald de Andrade, escrito na década de 1930 (cuja) recusa a que seu texto foi submetido no período em que foi escrito, não sendo levado ao palco, (se deu) apesar do desejo do autor em fazê-lo. ${ }^{53}$

Aqui se vê que mesmo baluartes do modernismo como Oswald de Andrade buscavam uma expressão teatral, apesar de se sentirem tolhidos de fazê-la por tais fatores. Frente a situações como essa, o movimento modernista buscava formas de associativismo para além de seu núcleo, “(...) encaminhando-se para um nacionalismo político de caráter popular" ${ }^{\natural 4}$, em oposição ao nacionalismo integralista que passava a contaminar o meio político.

Nisso, foram fundadas em 1931 a Sociedade Pró-Arte Moderna e a Família Paulista, com o objetivo de ampliar o campo de ação dos modernistas na sociedade. No entanto, mesmo a participação de importantes integrantes do movimento, como Lasar Segall e Mario de Andrade, dentro desses grupos não garantiu unidade de ação às iniciativas, que se desdobraram então na criação do Clube dos Artistas Modernos, fundado por Flávio de Carvalho - arquiteto de formação - no mesmo ano de 1931.

Flávio de Carvalho também se aproximou da produção teatral ainda que de um modo experimental, através do Teatro da Experiência, em 1933, em espetáculos de danças "folclóricas" (ou "bailados", como Flávio preferiu nomeá-los, possivelmente para fugir de nomenclaturas estigmatizantes) de modo que pareceu aleatório para muitos que na época entendiam uma manifestação teatral como uma expressão mais estática, mesmo após os fenômenos de Wassily Kandinsky e Josephine Baker terem quebrado essa impressão ainda no início do século XX. Porém, havia um método bastante apurado no modo de conceber a teoria e a produção almejadas nos experimentos.

\footnotetext{
${ }^{53}$ SIMÔES, 2009, p. $12-3$

${ }^{54}$ MATTOS, 2002, p. 136
} 
E apesar de Flávio de Carvalho e o grupo do Teatro da Experiência passarem longe do "teatro social" de Jaime Costa e Paulo Torres, tiveram que passar por muitos dos mesmos entraves antes e depois da interrupção após quatro dias das apresentações de sua peça "Bailado do Deus Morto" no Clube dos Artistas Modernos, como destacado nos trechos deste longo relato de Flávio de Carvalho resgatado tempos depois:

$O$ teatro seria um laboratório e funcionaria com o espírito imparcial de pesquisa de laboratório. Lá seria experimentado o que surgia de vital no mundo das ideias: cenários modos de dicção, mímica problemas de iluminação e som com intuitode formar uma base prática da psicologia do divertimento. [...]

Havia falta de autores. Pedi a diversos conhecidos a sua produção, porém tardavam, os aluguéis corriam e o dia da inauguração se aproximava. Escrevi o "Bailado do Deus Morto", uma peça cantada, falada, e dançada; os atores usavam máscaras de alumínio e camisolas brancas, o efeito cênico era um movimento de luzes sobre o pano branco e o alumínio. Passei dias inteiros na censura procurando convencer o delegado Costa Neto (o censor era Delegado de Polícia) e me faziam esperar horas e horas propositadamente. [...]

Após 10 dias de esforços inúteis contra o quebra-paciência oficial, por acaso eu peguei o delegado que se esquivava apressadamente na saida. Apelei por Shakespeare em plena Rua dos Gusmões, chamei atenção sobre a liberdade de linguagem desse autor o delegado atarantado, suado e com pressa se pronunciou verbalmente [...] Devido à natureza do instrumental os atores eram quase todos negros, pegados a esmo na rua. Hugo Adami, ator principal, tinha preconceito de raça, chegava atrasado aos ensaios ou não vinha. Pelo fato de já ter sido ator antes, não sabia direito a sua parte. A inauguração foi brilhante, um público variado e duas vezes maior do que a capacidade do teatro enchia o recinto e transbordava pela escada estreita dos altos do Clube dos Artistas Modernos. ${ }^{55}$

Considerando a libertação estética propiciada pelos modernistas, a reação sobre si de um reavivamento do aparato estatal repressivo às artes parecia um retrocesso sem tamanho. De qualquer forma, alguns dos mais proeminentes participantes do movimento agiram para impedir que esse sentimento de intimidação sobre a expressão artística crescesse. Mário de Andrade, um dos mais importantes poetas e escritores do movimento, se juntou a Paulo Duarte para formar o Departamento Municipal de Cultura em São Paulo em 1935, sendo inclusive seu primeiro diretor. Esse é considerado o

\footnotetext{
${ }^{55}$ Este relato foi registrado na Revista Anual do Salão de Maio (RASM) de 1939 e reeditado por José Mindlin, com patrocínio da empresa Metal Leve, em 1984, in: MAGALDI; VARGAS, 2001, p. 133-6
} 
primeiro órgão estatal específico para a cultura no país, com suas maiores preocupações se dando na questão musical, que era seu objeto de pesquisa particular, e na defesa do patrimônio histórico-cultural. Sua maior contribuição ao teatro como diretor do Departamento se deu na efetivação da demanda modernista de valorização da fala brasileira, ao organizar o Congresso de Língua Nacional Cantada que fixou oficialmente uma pronúncia padrão usada no teatro dramático e no canto do Brasil.

Os esforços de Mário de Andrade pela construção de uma estrutura estatal de proteção e promoção da cultura tiveram reflexo positivo muito por estarem em sintonia com a gestão de Gustavo Capanema no Ministério da Educação e Saúde Pública (MES) do governo de Getúlio Vargas. Capanema foi um político mineiro que ajudou na articulação de setores que se aliaram ao regime quando da derrota dos revoltosos de São Paulo na Revolução Constitucionalista de 1932, tendo inclusive se tornado brevemente governador interventor em Minas Gerais, e na Constituinte de 1934 que efetivou o mandato de Vargas. Com isso, foi elevado a partir de então a ministro de seu governo. $\mathrm{Na}$ formação do MES, Capanema colocou as questões de teatro, assim como as de cultura em geral, na chamada Divisão de Educação Extra-Escolar, retomando involuntariamente ideia de D. Pedro II de cultura como formação educacional do povo.

Ele ajudou a fundar o SPHAN (que se tornaria o IPHAN), órgão federal de preservação do patrimônio, preparando um relatório ${ }^{56}$ onde recomendava o tombamento de sete imóveis, todos do período colonial e barroco ligados à história religiosa da cidade. Apenas o Convento da Luz (hoje Museu de Arte Sacra) e a Capela de São Miguel Paulista foram tombadas durante seu período no cargo - três anos, de 1935 a 1938 -, mas ainda que os outros imóveis recomendados por ele só tenham sido efetivamente tombados a partir dos anos 1970, sua contribuição para o sucesso dessas demandas foi inegável.

Capanema foi inclusive o responsável por capitanear a fundação desse órgão federal junto a Gustavo Barroso, integralista participante do governo de Vargas que foi seu primeiro diretor, pelo Decreto-Lei N. ${ }^{\circ}$ 25, de 30 de Novembro de 1937. Não apenas pelo fato de ver seu projeto não ser acatado integralmente, mas também por um

\footnotetext{
${ }^{56}$ ANDRADE, Mário de. Anteprojeto para a criação do Serviço do Patrimônio Artístico Nacional; in: CAVALCANTI, 2000, p 37-52. Cf. na p.200.
} 
desconforto com os rumos da política nacional que desembocariam no Estado Novo getulista, Mario de Andrade deixa o Departamento de Cultura de São Paulo em 1938 ${ }^{57}$.

Enquanto Mário de Andrade experimentava uma espécie de autoexílio no Rio de Janeiro trocando suas impressões sobre o papel do intelectual frente ao Estado com o amigo Cândido Portinari, este último se tornava mais um integrante do time de notáveis da cultura convidados para comporem a assessoria de Capanema no seu ministério. Dentre eles, também estavam Carlos Drummond de Andrade - seu assessor direto -, Manuel Bandeira, Heitor Vila-Lobos, Cecília Meireles e Vinicius de Moraes. Essa convivência entre tantos nomes de importância e o ministério sempre se deu de maneira a que essa intelligentsia se comportasse como que servindo a um projeto de nação, e não aos designos de um governo.

Entretanto, tal convivência não se dava sem atritos políticos. Enquanto no início de sua gestão, a promoção da arquitetura modernista de Lucio Costa e Oscar Niemeyer foi muito valorizada, após a declaração do Estado Novo em 1938 o ministro Capanema encampou a ideia varguista de maior controle e fiscalização sobre as ações culturais contra a infiltração de "comunistas" - justificativa para instauração do novo regime por Vargas. Desse modo, tanto estes como outros colaboradores do ministério, como Graciliano Ramos, chegaram a ser perseguidos e até mesmo presos por qualquer sinal dessa militância, ainda que tenha levado um tempo até o Partido Comunista Brasileiro (o popular "Partidão") ser definitivamente posto na ilegalidade e desligado da vida política oficial.

Esses acontecimentos foram apenas amostras do quanto a década de 1930 trouxe para a cultura do Brasil e de São Paulo uma forte efervescência, após os movimentos artísticos das duas décadas anteriores buscarem se esquivar da nova composição política e assim começarem a se cruzarem com ela. A concentração dos esforços das elites paulistas na consolidação da política industrial e o acirramento dos conflitos com o governo de Getúlio Vargas que motivaram "revoluções” como as de 1924 e $1932^{58}$,

\footnotetext{
${ }^{57}$ Segundo Pires Júnior, “(...) esse afastamento não foi integral, na medida em que continuou a orientar alguns aspectos dos trabalhos de Luis Saia e principalmente de Oneyda Alvarenga, auxiliado por seu secretário que permaneceu em São Paulo", in: PIRES JÚNIOR, 2014, p. 5

${ }^{58}$ As chamadas Revoluções de 1924 e 1932 foram revoltas armadas contra ações do governo federal que consideravam prejudicar o Estado de São Paulo e fazê-lo perder sua influência na política nacional.
} 
buscavam para São Paulo uma retomada do controle total sobre os destinos políticos do país, agora concentrados no Rio de Janeiro após a quebra da "política do café com leite" 59 com Minas Gerais. Um dos meios de São Paulo tomar o protagonismo da capital federal foi desenvolvendo iniciativas culturais e educacionais. Tal movimento culminou na fundação da Universidade de São Paulo (USP) em 1934 e na "Missão Francesa"60 que trouxe Claude Levi-Strauss, Roger Bastide, entre outros, para lecionar.

Em meio a isso, um jovem Alfredo Mesquita voltava também da França, tendo passado pelo College de France em 1935 onde entraria em contato com o trabalho teatral de Jacques Copeau. Este encenador francês foi responsável por juntar artistas profissionais e amadores em sua Ecole du Vieux Colombier numa tentativa de resgate do trabalho de corpo do ator e de valorização do texto sobre a indumentária. Motivado por seus estudos que incluíram contato com a filosofia de teatro pregado por Copeau, e também pelos problemas que enfrentou com o que considerava sua "pátria de adoção", Mesquita voltou para São Paulo decidido a mudar os rumos da cultura no país.

Como herdeiro do jornal $O$ Estado de S. Paulo (sua família era proprietária do jornal desde 1902), Mesquita convenceu Procópio Ferreira a estrelar no Municipal sua peça “A Esperança da Família”, publicada pouco antes de sua partida à França, para ainda no mesmo ano juntar um novo Grupo de Artistas Amadores ${ }^{61}$ na encenação de sua peça “A Noite de São Paulo". Ainda que esteticamente seu teatro ainda carregasse ideias de um naturalismo que estava se tornando ultrapassado, sua presença marcante na cena do teatro paulistano viria a se tornar preponderante. Em relação a esses dois movimentos subsequentes e paralelos, os da valorização das artes e da ascensão de uma elite universitária pública, a resposta da arte teatral paulistana se deu na construção de um novo modelo, em busca de uma ansiada renovação estética no teatro brasileiro.

\footnotetext{
As diferenças entre elas é que a de 1924 foi uma incursão de militares contra o então presidente do estado (governador), e a segunda uma revolta civil convocada e financiada pela elite paulista.

${ }^{59}$ Essa política consistia num arranjo informal feito por políticos de São Paulo, grande produtora de café, e Minas Gerais, de larga produção pecuária, na troca mútua de indicações para a composição de chapas presidenciais da situação nas eleições. Washington Luís teria quebrado esse "acordo" em 1929 ao indicar outro paulista, Júlio Prestes, em detrimento do mineiro Antônio Carlos Ribeiro de Andrada.

${ }^{60}$ Cf. em: BIBLIOTECA NACIONAL, A missão francesa na Universidade de São Paulo. Disponível em: <http://bndigital.bn.br/francebr/intercambios.htm> Acessado em 21 de julho de 2019

${ }^{61}$ Esse grupo é diferente do grupo Os Artistas Amadores, do qual fizeram parte Madalena Nicol e Paulo Autran nos anos 40. Cf. na p. 49.
} 


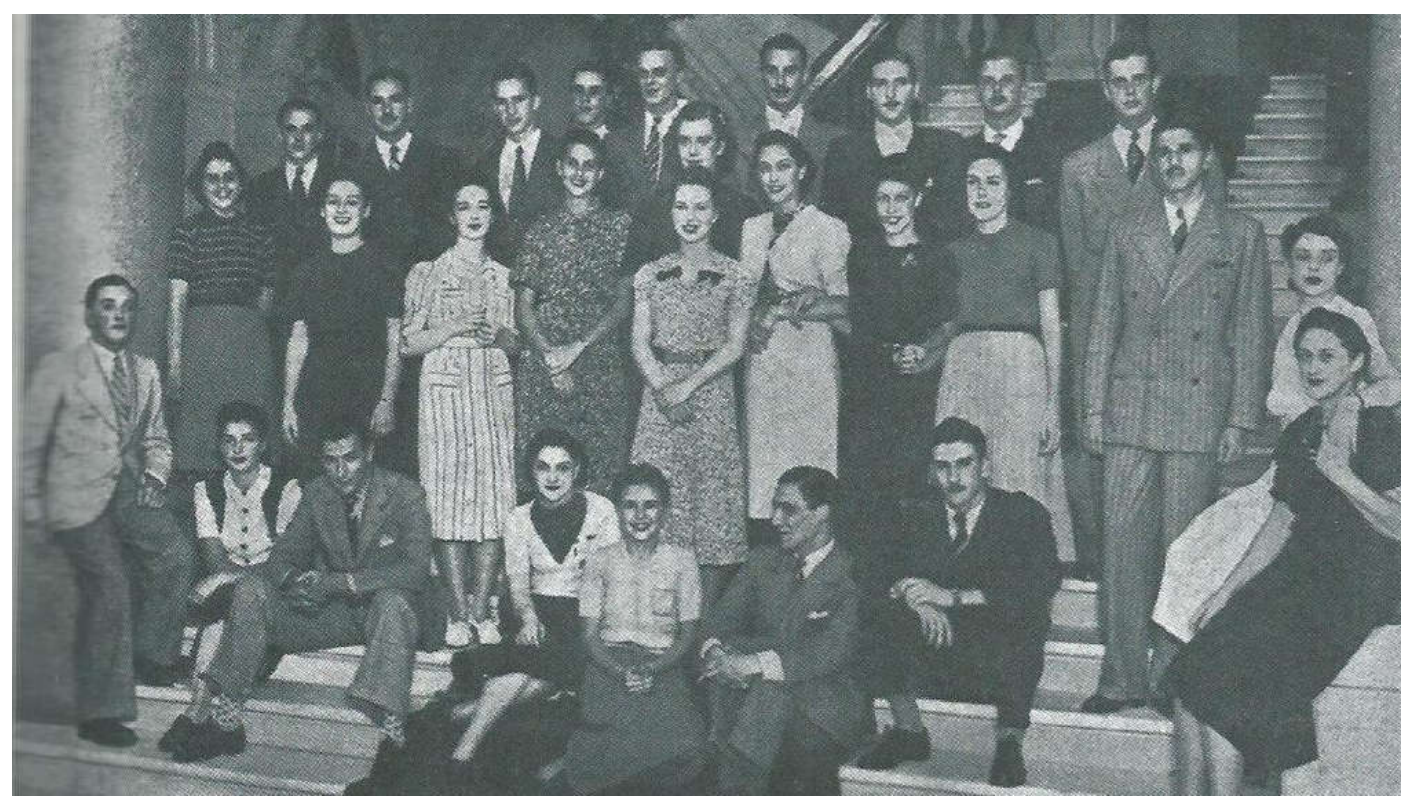

Imagem 6 - Alfredo Mesquita (junto à coluna da esquerda da foto) nas escadas do Teatro Municipal com o elenco de “A Noite de São Paulo" em 1938 (GÓES, 2007)

Outras iniciativas muito importantes do período no campo da formação, especificamente para as artes cênicas, foram a fundação da Academia de Belas Artes (hoje Centro Universitário Belas Artes) por Gomes Cardim ainda em 1925, iniciando trabalho de uma instituição privada (sem fins lucrativos) após seu trabalho no Conservatório e na Companhia Dramática de São Paulo; e o Teatro de Brinquedo, fundado em 1928 e considerado o primeiro "teatro-escola" nacional a partir do trabalho desenvolvido por Renato Vianna como “(...) primeiro teorizante das doutrinas estéticas da direção cênica"62 junto à Companhia Dramática Nacional.

Itália Fausta, que passou a colaborar com o projeto, nesse momento de sua carreira se encontrava bastante atuante fora dos palcos - tornando-se presidente da Casa dos Artistas e participando de movimentos do meio teatral. Ela ajudou a dar ao trabalho de Renato Vianna o respaldo necessário para sua imcorporação na estrutura da CDN. Isso se deu também por certa influência de Ronald de Carvalho, que trabalhou com Vianna em projetos anteriores e era então secretário da Presidência no governo de Vargas. Fausta, de certa forma, superou a Vianna no trabalho de formação ao fazer colaborações com outros grupos estudantis surgidos e estabelecidos naquele momento, como a Companhia de Arte Dramática, de Álvaro Moreira, e o Teatro do Estudante, de

${ }^{62}$ SILVEIRA, 1976a, p. 289 
Paschoal Carlos Magno, onde “(...) se dispunha a ensinar (um trabalho) de encenação apoiado no estudo e na experiência". ${ }^{63}$

A reivindicação de uma escola dramática ligada à universidade era uma dentre várias demandas históricas trazidas pela SBAT, com a finalidade de facilitar o trabalho dos artistas do teatro e suas possiblidades de reposição profissional em um nível mais elevado. Nos Boletins da SBAT de 1934, foram publicadas propostas que a entidade levou para o governo federal reivindicando isenção de impostos para a construção de casas de espetáculos e o abatimento de $60 \%$ no preço das passagens para as companhias em turnê pelo país. A demanda do "teatro-escola" junto à estrutura federal existente havia se tornado, enfim, a primeira a se tornar realidade dentro do que Getúlio Vargas pensou para ganhar o apoio do teatro estabelecido.

O conceito de "teatro-escola" do Teatro de Brinquedo, inserido na estrutura da CDN portanto submetido ao Estado, foi definitivamente abarcado pelas políticas estatais de duas maneiras. Primeiro, por uma turnê por São Paulo em 1937 patrocinada pelo Ministério da Educação e Saúde ${ }^{64}$ de Gustavo Capanema, onde foi apresentado um repertório de caráter didático a estudantes no Teatro Boa Vista, supervisionados pela "diretora de cena" Itália Fausta, com ingressos a quatro mil réis. Depois, na incorporação de seu método por Getúlio Vargas na nova política cultural pensada por ele para o teatro por influência de reivindicações da Casa dos Artistas, e consolidada ao se criar a Comissão de Teatro Nacional em 13 de janeiro de 1937 como um "órgão de execução" junto ao Ministério.

A Comissão instituída junto a personalidades do meio teatral de várias vertentes, como Olavo de Barros (pela Casa dos Artistas), Oduvaldo Vianna, Sergio Buarque de Hollanda, entre outros, era responsável por fazer publicações sobre teatro, além de tratar de subvenções a grupos profissionais e amadores, construção de teatros e promoção de espetáculos ligados às raízes nacionais. A censura a espetáculos prosseguia corrente, porém a responsabilidade pelas decisões a respeito não passava por esse departamento, ficando a cargo diretamente da Polícia do Distrito Federal e posteriormente do

\footnotetext{
${ }^{63}$ SILVEIRA, 1976a, p. 291

${ }^{64}$ A Lei n.378, que também criou a Comissão de Teatro Nacional, mudou também a denominação do ministério ao suprimir o "Pública" do nome Ministério da Educação e Saúde.
} 
Departamento de Imprensa e Propaganda (DIP) do regime do Estado Novo ${ }^{65}$.Com estudos diversos e aprofundados das questões teatrais, em dezembrode 1937 houve um reconhecimento do governo àsreivindicações da categoria com a criação do Serviço Nacional do Teatro (SNT) em substituição à Comissão.

O SNT foi um órgão público regulador e fomentador do teatro no país, que funcionou em paralelo aos ministérios ligados à cultura ao longo do tempo, como o MES, MEC (Educação e Cultura) e finalmente o Ministério da Cultura até 1990. Suas atribuições eram bem completas, e por isso o órgão atravessou governos de matizes diversas. Além de fazer aquilo a que a Comissão já se dedicava, o SNT tratava também de incentivar novos grupos de amadores em locais de reunião social (clubes, fábricas, escolas), fomentar a produção de obras nacionais e providenciar a guarda de acervo dramatúrgico nacional junto à tradução de originais estrangeiros.

Apesar de o cargo de diretor do SNT ter um pagamento equivalente ao do ministro, sua grande responsabilidade frente ao meio teatral fez com que num primeiro momento Oduvaldo Vianna e Mário de Andrade recusassem a chefia do órgão, fazendo com que a mesma ficasse vaga por quase um ano com seus recursos sendo liberados "sob os auspícios da Comissão de Teatro do Ministério",66, que estava extinta mas cujas resoluções ainda eram levadas em conta pela falta do diretor para o SNT. Isso aconteceu até que em agosto de 1938 o dramaturgo Abadie Faria Rosa, indicado por Vargas por seu trabalho na SBAT, foi finalmente empossado na chefia.

As ligações de associações de classe com o governo passaram então a ser explicitadas a partir desse convite expresso pelo Presidente. Os Boletins da SBAT publicados no ano de 1937, pouco antes da promulgação do Estado Novo e da constituição da Comissão de Teatro, eram para muitos no meio "de extrema bajulação e apoio a Vargas e Capanema"67, chegando ao ponto de darem apoio explícito às intenções de Vargas no fechamento de seu regime e recebendo assim cumprimentos do presidente pelo apoio.

\footnotetext{
${ }^{65}$ CAMARGO, 2010, p.5

${ }^{66}$ MAGALDI; VARGAS, 2001, p. 161

${ }^{67}$ BARROS, Orlando de. A guerra dos artistas: dois episódios da história brasileira durante a Segunda

Guerra Mundial, E-Papers, 2010, p. 30
} 
A entrada da comissão e do SNT no cotidiano das companhias teatrais levou a uma onda de otimismo, com muitos espetáculos produzidos com diversos níveis de pretensão artística, desde teatro musicado inspirado em modismos do cinema ou canções líricas, até dramas e comédias com personagens históricos. Porém, apesar de levar em conta uma lógica regulatória na sua política pública para o teatro, no sentido de construir uma burocracia própria para decidir quem receberia ou não os benefícios concedidos, no seu início parecia evidente que a iniciativa da Comissão acabava reproduzindo a hierarquia das companhias existentes na concessão de subsídios, não apenas a gêneros considerados mais elevados como aos intérpretes de maior retorno.

Levantamento dos espetáculos subvencionados pelo SNT na cidade de São Paulo em seu primeiro ano, ainda sob vigência de critérios da Comissão, ${ }^{68}$ contabilizou dezoito peças auxiliadas, sendo Dulcina de Moraes e Raul Roulien alguns dos que se utilizaram dos recursos para temporadas mais longas (Dulcina chegou a produzir espetáculo com cem contos de réis, valor exorbitante para a época). Nomes como Alfredo Mesquita, Jaime Costa e Procópio Ferreira também foram contemplados em produções próprias. Apesar de amadores terem sido também contemplados, algumas distorções anteriores acabaram reforçadas por essa política.

A partir da posse de Abadie Faria Rosa, os critérios de concessão tiveram alguma mudança a partir de um edital aberto em 1939 em que gêneros mais variados como a revista acabaram contemplados. Porém, a falta de critérios claros para tanto forçou Capanema a vetar a partir de então a participação de empresários como proponentes a auxílios e prêmios, fazendo com que apenas companhias consideradas estáveis e em sede fixa se inscrevessem. A partir disso e por um bom tempo, a maior parte das subvenções tanto para profissionais como amadores se deu para excursões e pagamento de aluguéis das sedes de companhia, possivelmente a despesa corrente mais comum aos teatros da época.

Alijadas dessa concorrência por decisão governamental ou própria, as companhias estrangeiras ou de origem imigrante traziam aos palcos um frescor que não passou despercebido, como foi o caso do grupo de amadores ingleses English Players,

\footnotetext{
${ }^{68}$ MAGALDI; VARGAS, 2001, p.161-6
} 
ligados à Sociedade de Cultura Inglesa ${ }^{69}$, que se tornam célebres em uma interpretação com Dulcina de Moraes em 1938; e de grupos visitantes franceses como se deu em 1938 com o Theatre des Quatre Saisons, grupo que parte dos ensinamentos do francês Jacques Copeau que tanto influenciaram Alfredo Mesquita e seus amadores; e em 1941 com a companhia de Louis Jouvet, que conta inclusive com apoio governamental e do Consulado de seu país. Eles se consolidam como alguns dos grandes inspiradores da nova geração de formadores dos encenadores brasileiros, particularmente nas escolas e locais estabelecidos a partir das novas diretrizes do Ministério da Educação e do SNT.

As novas diretrizes técnicas foram colocadas por estatuto do órgão governamental que em 1941 que, entre outras coisas, fixou a importância da figura do encenador, delimitando suas funções como as mais importantes dentro de uma montagem teatral ao dar a ele poderes maiores sobre o controle das atividades no palco, quanto aos ensaios, horário de trabalho dos atores e ao planejamento de ações a serem apresentadas à administração do grupo, separando assim suas atribuições das do corpo administrativo.

Essas regras estabelecidas pelo regulamento do SNT embasaram a criação da Comédia Brasileira, companhia estatal que intencionava suplantar iniciativas anteriores de se formar uma companhia nacional ${ }^{70}$ para almejar se firmar como a primeira companhia estatal de excelência a se tornar profissional. Contudo, tendo escolhido seus participantes a partir de critérios estabelecidos no teatro tradicional (portanto com formação diferenciada), aliado à dificuldade de adaptação aos novos preceitos e um repertório pouco criterioso, a iniciativa da Comédia Brasileira teve fim em 1945.

1945 também marcou o fim do governo de Getúlio Vargas, que após 15 anos de regimes de diferentes ordens, com períodos mais centralizadores alternando a outros mais democráticos, acabou deposto do poder. Antes de deixar o cargo, Vargas deu um aceno final para o teatro em anúncio no dia 17 de setembro no Teatro Municipal do Rio

\footnotetext{
${ }^{69} \mathrm{O}$ trabalho do grupo English Players se solidificou a partir da fundação da Sociedade de Artistas Amadores de São Paulo, ou Amateurs' Society, que congregou comerciários e funcionários de firmas britânicas, também imigrantes, a representarem na língua inglesa. Ela tinha distante ligação com órgãos oficiais e privados, tendo em sua direção Irene "Pussy" Smallbones, filha do cônsul inglês da época, e Ronald H. Eagling, que trabalhava na Gessy Lever e em 1965 acabou como presidente no Rio de Janeiro do British Community Council - até hoje ligado à Sociedade de Cultura Inglesa e ao consulado britânico. Cf. em: MATTOS, 2002, p. 211

${ }^{70}$ FARIA, 2012, vol. 1, p. 484-5
} 
para passar a limpo as reivindicações da SBAT que considerava não atendidas até então. Após o fim da CDN e do projeto do Teatro de Brinquedro, instituiu-se a criação do Curso Prático de Teatro, experiência que durou até 1954 em sua primeira configuração. A medida que permaneceu por mais tempo, e que teve efeito para além da capital federal, dizia respeito à pedida isenção de impostos para construção de teatros, pelo Decreto-Lei N. 7957, que dizia que um prédio construído como teatro até cinco anos depois do decreto deveria permanecer com tal uso por ao menos quinze anos.

Fora do esquema estatal mas ainda sob sua órbita, os resultados dessa junção entre artistas brasileiros e os locais de formação universitária pública foram a base da criação da revista Clima em 1941, que ao aglutinar gente como Alfredo Mesquita, Décio de Almeida Prado, Antonio Candido, Paulo Emilio Salles Gomes e Lourival Gomes Machado, buscava institucionalizar os sentimentos pulsantes do Modernismo sob um outro patamar de exigência artística, tendo a Livraria Jaraguá, fundada por Alfredo para garantir fonte de renda ${ }^{71}$, como ponto de encontro desses intelectuais.

O trabalho dos grupos teatrais amadores oriundos da universidade, que passaram a surgir com as políticas do SNT, passou a abarcar participantes de vários estratos sociais, desde filhos de famílias ricas e aristocratas da velha sociedade paulista como os filhos dos imigrantes com alguma formação artística anteriorgraças a experiências amadoras da família. Mas o grande diferencial destes em relação aos atores estabelecidos do período estava além da vontade dos universitários de fazer um teatro diferente. Isso se deu principalmente na maior consciência de “(...) uma nova mentalidade, que já estava no teatro europeu desde as últimas décadas do século XIX e que o profissionalismo brasileiro teimava em desconhecer" (MAGALDI; VARGAS, 2001, p. 178): a de que o encenador, e não mais o ator principal da companhia, era a figura central a quem o grupo deveria seguir em suas ações, e também que o poder de decisão das companhias teria uma divisão de responsabilidades mais equilibrada dali por diante, além de um parâmetro de deveres e objetivos padronizado. Os grupos principais surgidos desse movimento em São Paulo são o Grupo de Teatro Experimental (GTE), fundado por Alfredo Mesquita em 1942, e o Grupo Universitário de Teatro (GUT), fundado em 1943 por Décio de Almeida Prado.

\footnotetext{
${ }^{71}$ Com a intervenção na empresa feita por Getúlio Vargas em O Estado de S. Paulo em 1940, a família de Mesquita fica sem os dividendos vindos do jornal. Cf. em: POMPEU DE TOLEDO, 2015, p. 389
} 
Esses grupos com jovens vindos majoritariamente dos cursos de Direito e Filosofia da USP, com gente como Abílio Pereira de Almeida e Nydia Lícia entre eles, se contrapunham ao Teatro do Estudante do Brasil e aos Comediantes, sediados no Rio de Janeiro e com o mesmo caráter formativo em busca de uma nova expressão para o teatro brasileiro.

É de se considerar que ambos tenham iniciado seus trabalhos em 1943 com um grande espírito colaborativo entre si, ao promoverem excursões conjuntas pelo interior do estado com ambos os fundadores na composição administrativa do grupo então mais estabelecido naquele momento, o GTE, com Décio como presidente e Alfredo como diretor artístico. Alfredo também se comportava como uma espécie de mecenas do GTE, colocando muitas vezes dinheiro do próprio bolso para a produção de suas montagens - foi ele quem pagou, por exemplo, o aluguel do Teatro Municipal para a primeira apresentação "solo" do GTE encenando peça do romântico francês Alfred du Musset na língua original; a peça seguinte do grupo, também de um autor francês e também no Municipal, foi encenada em português.

Essa escolha do autor francês, apesar de parecer uma concessão anacrônica a um modo de pensar e fazer teatro que eles pareciam combater, era condizente com as diretrizes iniciais do GTE cujo intento para Mesquita era “(...) contribuir para a formação de um teatro nacional, tanto nas peças e autores como nos atores e cenógrafos, educando para isso o gosto do público (para) peças estrangeiras que não integrem o repertório das companhias profissionais (de então) enquanto não houverem boas peças nacionais" (MAGALDI; VARGAS, 2001, p.176). Esse parece ter sido um motivo para a escolha tanto de um autor francês como Musset, esquecido denro do cânone, como dos emergentes modernos que foram sendo prestigiados a partir de então.

Essas diretrizes da fundação do GUT também mostram que, apesar de terem sido impulsionados a ir além dos muros da universidade pelas novas políticas do SNT, não obtiveram através deste órgão a sua fonte de recursos primária para manutenção ou para suas atividades externas, mas de fundos da universidade onde estavam sediados. Em nota do programa da excursão com o GTE em 1943, diz-se que o GUT foi fundado “(...) como expressão do movimento que ora atravessamos, com o propósito de colaborar na obra magnífica dos Fundos Universitários de Pesquisa para a Defesa Nacional, e 
paralelamente construir um centro permanente de interesse pelo teatro., ${ }^{, 72}$ Esse fundo foi criado pela USP em 1942 através do reitor Jorge Americano, para financiar projetos e pesquisas da universidade no período da Segunda Guerra Mundial, para que estas se tornassem independentes da oscilação orçamentária estatal no período delicado atravessado pelo país, que havia entrado no campo de batalha.

Esse fundo era de tal importância para a universidade que o próprio reitor acompanhava, junto a outos dois professores da universidade - André Dreyfus e Jaime Regalo - as excursões do GUT para saberem que o dinheiro estava sendo bem usado. Durante a turnê, o grupo ainda pedia também por contribuições para complemento às despesas do grupo e pela continuidade do fundo, que foi também o embrião de agências de financiamento universitário como a FAPESP. ${ }^{73} \mathrm{O}$ fato de que o fundo teve prosseguimento após o final da guerra (apenas perdendo o epíteto em prol da "defesa nacional") foi também fundamental para que o trabalho do GUT pudesse se prolongar em sua busca por estabelecer novos parâmetros de inovação teatral.

Um elemento que acabou se tornando importante para a consolidação dos grupos universitários dentro do circuito foi a incorporação de Cacilda Becker em espetáculos do GUT. Ela, que tinha para si o típico histórico dos artistas que vinham do interior para se estabelecerem nos grandes centros, passou por grupos do Rio de Janeiro e desde 1941 vinha para São Paulo fazer apresentações, como na temporada da companhia de Raul Roulien no Teatro Boa Vista naquele ano. Convidada por Décio de Almeida Prado a se apresentar junto aos amadores do GUT em $1943^{74} \mathrm{em}$ momentos sem trabalho no Rio, ela ajudou a quebrar a resistência de um dos próceres do modernismo brasileiro, Oswald de Andrade, em relação ao teatro paulistano numa oposição aos que ele chamava de "chato-boys" que teriam para ele dominado a cultura paulistana a partir da reunião do grupo da revista Clima.

Além da crítica, o apoio fora da universidade aos grupos se consolidava com apoio da Sociedade de Cultura Artística, ainda em busca de construir seu espaço próprio e que via na ascensão dos grupos universitários um impulso para a concretização de seu

\footnotetext{
72 MAGALDI/; VARGAS, 2001, p.176

${ }^{73}$ Cf. em: JAGLE, A. e SZMRECSÁNYI, T. Pesquisa \& Desenvolvimento. São Paulo: FAPESP, 1973

${ }^{74}$ Segundo Arnoni Prado, como crítico da revista Clima, Décio de A. Prado foi o primeiro a descrever Cacilda como “(...) uma fusão entre a pessoa e a personagem, corpo e texto", in: PONTES, 2011, p.174
} 
desejo. Mas nem tudo era otimismo no teatro paulistano da época. Em 1946, houve uma grande passeata dos artistas do teatro em relação à falta espaços cênicos na cidade, sob o mote "São Paulo Quer Teatros", visto que os espaços estavam desaparecendo vertigionamente devido a demolições para obras viárias e à crise do setor.

Os teatros eram definitivamente substituídos pelos cinemas - muitos espaços que dividiam sessões entre uma e outra arte, como o Colombo, optaram por apenas exibir filmes - ou eram definitivamente derrubados pela crescente urbanização, com os únicos teatros oficiais abertos naquele ano sendo o Boa Vista, o Santana ${ }^{75}$ e o Municipal. O Teatro Boa Vista, apesar de receber muitas companhias, estava em crise e acabaria fechado no ano seguinte; o Santana era praticamente restrito ao gênero do teatro de revista; e o Municipal era prioritariamente dedicado à música lírica.

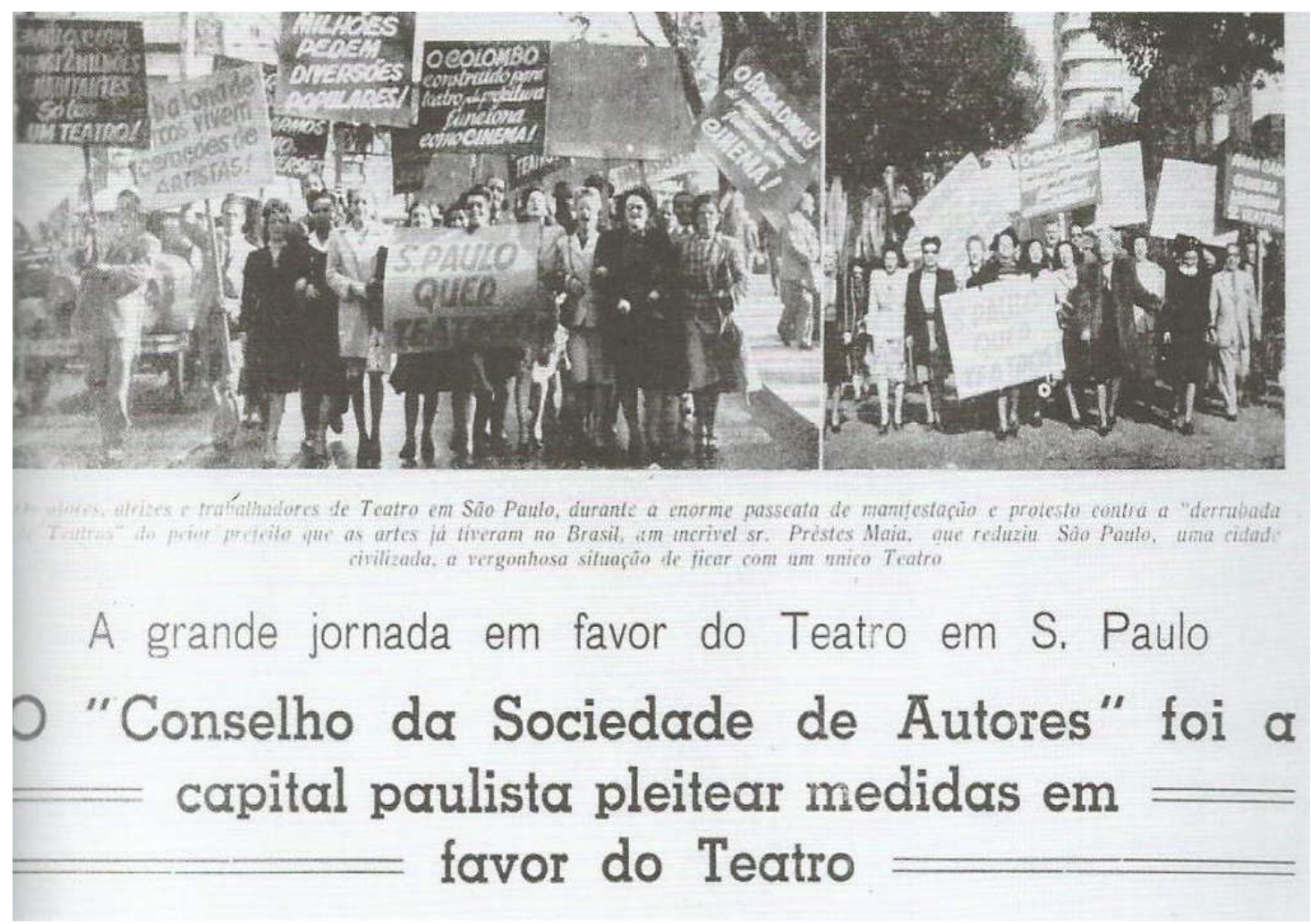

Imagem 7 - Passeata em favor dos teatros de São Paulo. Fonte: revista Comoedia (MAGALDI;VARGAS, 2001)

${ }^{75}$ Este teatro é diferente do Sant'Anna que funcionava no início do século XX e foi construído por Antonio Álvares Penteado (Cf. na p. 76). O primeiro ficava na Rua Boa Vista e foi demolido em 1912. O novo Sant'Anna estava na Rua 24 de Maio e foi aberto em 1921 com capacidade para mais de 1300 pessoas. Foi fechado em definitivo em 1957 e demolido no ano seguinte. Cf. em: SACONI, Rose. Era uma vez em SP: Teatro Santana. In: O Estado de S. Paulo, 22 de maio de 2015. Disponível em: <https://acervo.estadao.com.br/noticias/acervo,era-uma-vez-em-sp-teatros-santana,11086,0.htm> Acessado em 16 de julho de 2019 
A passeata foi então organizada pela SBAT e contou com a presença de artistas de todos os gêneros teatrais, desde os universitários e profissionais, os da revista, teatro musicado, e até do circo como o Palhaço Piolin. Apesar de a passeata ter tido grandes proporções e ser recebida tanto pelo prefeito de São Paulo, Abrahão Ribeiro, como pelo governador interventor do Estado de São Paulo, Macedo Soares, não se tirou a impressão geral de que o poder público abandonara a cultura da cidade à própria sorte.

As iniciativas dos grupos de profissionais estabelecidos passaram a rarear; os grupos universitários voltaram a fazer programação conjunta ao mesmo tempo que o GTE precisava ensaiar na casa de Alfredo, na Avenida Higienópolis, ou na Livraria Jaraguá enquanto reclamava de 50 mil cruzeiros de impostos pagos sem retorno e pedia coletas para presentes às suas apresentações; e os espaços culturais voltaram a ser majoritariamente ocupados por companhias de outras cidades,principalmente do Rio de Janeiro como Os Comediantes, já profissionalizados com Ziembinski na direção e Cacilda Becker e Maria Della Costa no elenco, com sua junção de "Desejo", de Eugene O’Neill e a nova versão de "Vestido de Noiva" de Nelson Rodrigues após a consagradora montagem de 1943, juntando com sucesso dramaturgia estrangeira e brasileira em produção e desenvoltura inigualável para um grupo brasileiro.

Desse cenário em que o teatro paulistano parecia estar involuindo em relação ao crescimento vertiginoso da cidade, passou-se então a lentamente eclodir a emergência de um novo empreendedorismo cultural. Corria o ano de 1945 quando um grupo seleto de trinta a quarenta pessoas da elite paulistana ${ }^{76}$ se encontrava para convescotes dominicais que se transformavam em verdadeiros saraus na casa onde morava Franco Zampari, engenheiro italiano contratado pelas indústrias Matarazzo, ou na de Paulo Assumpção. Havia também uma frequência tanto de uma ala ligada aos grupos amadores, desde integrantes do GUT e GTE até Madalena Nicol e Paulo Autran ${ }^{77}$ ligados naquele momento ao grupo Os Artistas Amadores, que iniciava seu trabalho no teatro com algum destaque-, assim como burgueses industriais e rentistas como Francisco Matarazzo Sobrinho, mais conhecido pelo apelido Ciccillo.

\footnotetext{
${ }^{76}$ Segundo relato de Ruy Afonso, integrante dos grupos universitários e assíduo frequentador dos encontros, in: MATTOS, 2002, p. 49

${ }^{77}$ Madalena Nicol era sobrinha de Leonor de Barros, esposa do governador do estado; Paulo Autran havia se formado em Direito e abandonou a carreira pelo teatro. Cf. em LícIA, 2007, p. 22-3
} 

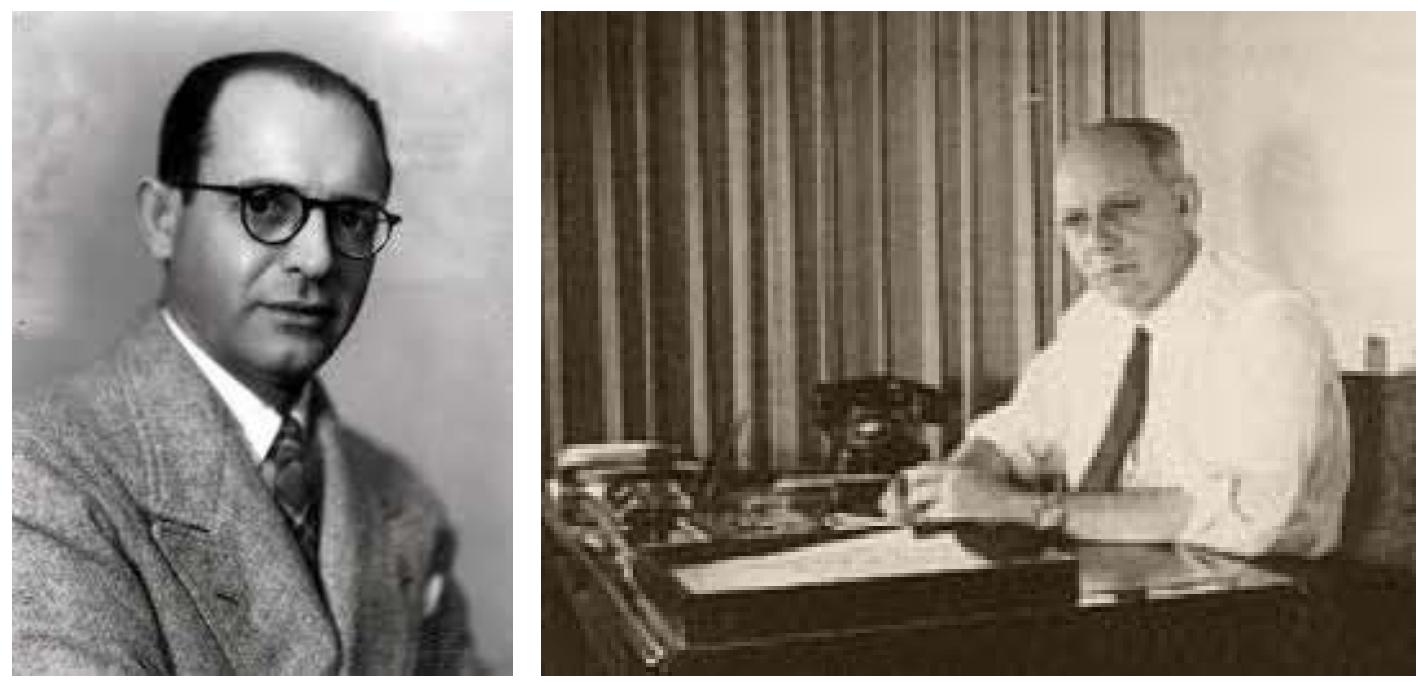

Imagem 8 - Ciccillo Matarazzo e Franco Zampari

Franco Zampari e Ciccillo Matarazzo eram muito amigos, tendo crescido juntos em Nápoles e tiveram seus destinos novamente cruzados em São Paulo, com Ciccillotendo voltado antes para São Paulo em 1918 para cuidar dos negócios da família e Zampari vindo trabalhar nas indústrias Matarazzo em 1922 a pedido do amigo e para acompanhar a esposa brasileira. Ciccillo era rico e Zampari de riqueza ascendente, tendo reservados para ele e esposa as cadeiras 1 e 3 da fileira C do Teatro Municipal, além de morar no Jardim América, bairro da nova elite da cidade, tendo já comprado terrenos no então distante bairro do Morumbi, que na época era formado por nada além de chácaras e que a especulação imobiliária dizia que se tornaria um lugar diferenciado.

Ambos eram entusiastas das artes. Em um ambiente com tantas pessoas envolvidas com o teatro paulistano, esses burgueses $\mathrm{e}$ aspirantes à elite se entusiasmavam em dar alguma forma de contribuição à arte do teatro, como forma de retorno à cidade que os enriqueceu. Primeiro, tentou-se fazê-la artisticamente: um grande encontro em setembro de 1945 foi organizado na casa de Paulo Assumpção para a apresentação de texto original de Zampari, em um esforço artístico ensaiado com um grupo durante um ano inteiro em sua casa. A apresentação foi um sucesso, se não artístico, anímico o bastante para fazer o entusiasmo de Zampari se elevar a ponto de lançar ali uma campanha em prol da “(...) ideia de criar em São Paulo um teatro destinado à apresentação de obras dramáticas modernas, de reconhecida importância internacional., 78

${ }^{78}$ MATTOS, Op. Cit., p. 50 
Zampari, que já havia se aproximado de Alfredo Mesquita após tê-lo ajudado com trinta contos de réis, ou trinta cruzeiros ${ }^{79}$ na campanha decontribuição em uma das apresentações do GTE em $1945,{ }^{80}$ se prontificou desde então a apoiar quaisquerprojetos teatrais dele. Os encontros animados e assíduos entre os artistas do teatro em sua casa o incitaram ainda mais a seguir no seu desejo de influir nos rumos da cultura paulistana, algo também pretendido por Alfredo. Faltavam pensar nos meios para fazer acontecer os seus desejos por um teatro próprio, grande desejo de Alfredo Mesquita e o sonho acalentado de Franco Zampari para ser reconhecido definitivamente como parte da elite paulistana a deixar sua marca na cidade que o acolheu. E depois de tanto o teatro brasileiro buscar um modelo acabado para que sua expressão se tornasse verdadeiramente esplêndida e digna de aplausos, o momento justo para isso parecia finalmente ter chegado.

\footnotetext{
${ }^{79}$ Desde 1942, a moeda brasileira era oficialmente chamada de cruzeiro, sendo assim assinada em documentos contábeis e oficiais, mas ainda foi por muito tempo conhecida como réis ou a partir dos "contos de réis" (mil réis), tal como o foi durante todo o século XX. A correspondência com os valores mencionados até aqui é de que um cruzeiro valia mil réis, ou um conto de réis, e dez réis valeriam um centavo de cruzeiro. Fonte: BANCO CENTRAL, Atualização de valores. Disponível em: <https://www.fee.rs.gov.br/servicos/atualizacao-valores/> Acessado em 24 de julho de 2019 ${ }^{80}$ GÓES, 2007, p.150
} 


\section{CAPÍTULO2: O TBC e suas relações com o poder público: empréstimos, intervenções e defesa do seu patrimônio}

\subsection{Implementação do projeto TBC}

São Paulo vivia um momento especial na sua história a partir da metade dos anos 1940. O governo Getúlio Vargas, tão combatido pela elite paulista a ponto de fazê-los entrar em uma guerra secessionista que colocou o povo a serviço de seus interesses, e de incitar movimentos políticos reacionários para barrar suas investidas políticas, estava chegando a um fim apesar de políticas de abertura e de conciliação de classes como a promulgação da CLT e das Leis do Trabalho em 1943. Motivadas pelo fim da Segunda Guerra Mundial, as discussões pelas atitudes ambivalentes de seu governo para com os dois lados da batalha, o Eixo e os Aliados, desgastaram o governo com o levante de movimentos de contestação cívico-militar.

Durante a Segunda Guerra, oficialmente o regime vivia desde o início da guerra de ataques retóricos e concretos a órgãos de apoio aos Aliados, como a Sociedade dos Amigos da América fechada por uma invasão de tropas em 1943, para pouco depois ao finalmente entrar na guerra ao lado destes que antes atacava, iniciar um expurgo da infiltração cultural de imigrantes dos países do Eixo - Alemanha, Japão e Itália, de forte presença de imigrantes em certas áreas do país. O questionamenteo a essas atitudes ensejou brigas políticas desde a base até a cúpula de seu governo, enchendo as ruas de manifestações de estudantes até chamamentos pela campanha de um brigadeiro (Eduardo Gomes) como líder da oposição à presidência. Renúncias como a do Ministro do Exterior, Oswaldo Aranha, fizeram com que também Vargas não suportasse a pressão forçando-o a convocar eleições para 9 de dezembro de 1945, as quais dizia não ter a intenção em concorrer. ${ }^{81}$

Mais do que nunca, esse novo movimento político rumo à mudança desejada pelo poder paulista injetou tanto nas velhas elites agrárias, como nos novos ricos fruto da industrialização e da imigração, um sentimento de que valeria a pena investir não

\footnotetext{
${ }^{81}$ Cf. em: FUNDAÇÃO GETÚLIO VARGAS, Diretrizes do Estado Novo (1937 - 1945)- Queda de Vargas e fim do Estado Novo, FGV/CPDOC, Disponível em: <https://cpdoc.fgv.br/producao/dossies/AEraVargas1/anos37-45/QuedaDeVargas> Acessado em 19 de julho de 2019
} 
apenas na continuidade desse crescimento econômico, mas também na consolidação de como essa elite pensa que deveria ser a sociedade paulistana e brasileira, seja social como culturalmente. São Paulo se tornava mais do que nunca o símbolo algo ufanista “(...) dos que pensam o Brasil como "país do futuro" (...) numa história que não se faz em um dia (como) evidência de que o nosso presente é rico de forças que trabalham para um futuro melhor. ${ }^{, 82}$

Uma evidência de que o planejamento para esse momento já estava em curso entre os dirigentes paulistanos se deu no campo da reforma urbana. Para abarcar seu crescimento, a cidade de São Paulo consolidava desde os anos 1930 até o fim dos 40, por meio de Luis Inácio Anhaia Melo e Prestes Maia, uma ideia de urbanismo arquitetônico com estilo importado dos Estados Unidos batizada de "City Beautiful" (Cidade Linda), que através de um modelo administrativo chamado de "scientic management school” (escola de administração científica) buscava “(...) separar a linha de pensamento que privilegia soluções técnicas para problemas administrativos (em relação à) administração dos conflitos que ocorrem na arena política" ${ }^{\natural 3}$.

Com isso, abandonava-se qualquer pretensão em fazer nas cidades brasileiras novas construções de prédios art nouveau ao estilo francês, como era priorizado nas políticas de reforma urbana no Rio de Janeiro da primeira metade do século 20. Dessa forma, se marcava uma separação das soluções urbanísticas encontradas pelas autoridades de São Paulo em relação às feitas na metrópole federal, algo que se vislumbrava pelas construções imponentes de prédios administrativos estatais ou de grandes corporações bancárias. O símbolo maior disso se tornou o prédio do Banco do Estado de São Paulo (BANESPA), banco estatal cujo prédio inaugurado em 1947 no centro de São Paulo imitava o desenho do Empire State de New York.

Nesse processo de "metropolização" da $\operatorname{cidade}^{84}$, além da quantidade de indústrias, operários e outros trabalhadores, a população da cidade crescia aumentando

\footnotetext{
${ }^{82}$ FERNANDES, Florestan. Mudanças sociais no Brasil, São Paulo: Difusão Europeia do Livro, 1960, p.303, in: ARRUDA, 2001, p. 31

${ }^{83}$ Cf. GRAHAM, Lawrence S. Civil Service Reform in Brazil, University of Texas, 1968: in: FELDMAN, Sarah. Os Anos 30 e a Difusão do Urbanismo Americano no Brasil. ResearchGate, p.3. Disponível em: <https://www.researchgate.net/publication/277842457_Os_anos_30_e_a_difusao_do_urbanismo_ame ricano_no_Brasil> Acessado em 19 de Julho de 2019

${ }^{84}$ LOVE, Joseph. A locomotiva: São Paulo na Federação Brasileira 1889-1937. São Paulo: Ed. Paz e Terra, 1982, in: ARRUDA, 2005, p.137
} 
de 2,2 milhões de habitantes em 1929 para 4,4 milhões em 1938. Crescia também uma maior qualificação e sofisticação destes, diversificando assim a demanda de consumo e os produtos oferecidos no mercado, num movimento que deu ao país certo grau de autonomia nesse tipo de produção, ainda que João Manuel Cardoso de Mello (1982) alertasse para o fato de que a indústria paulista ainda era restringida em sua produção, tornando-se pesada apenas a partir de $1955^{85}$. O grau de elaboração de diferentes setores da economia contribuía para que ao mesmo tempo em que os serviços empregassem $50 \%$ da mão de obra em 1940 , a indústria produzia $70 \%$ do que era feito do país. ${ }^{86}$

Além do impacto dessa influência na construção civil, essa política urbana influiu também em outros modos de produção, como o do Liceu de Artes e Ofícios. Com o passar dos anos, começa a acontecer no local uma separação entre a produção industrial de materiais para construção (a LAO-Indústria, especializada na fabricação de hidrômetros, medidores de gás e materiais para a construção civil) e o ensino técnico das habilidades a que eles se dedicavam, incluindo aí as áreas artísticas. Esse processo se consolida na virada das décadas de 1940 para 1950. Nesse sentido, a cultura também acaba se beneficiando do processo de adensamento e massificação da metrópole, pela gradativa sofisticação das demadas da economia e da população consumidora.

No campo artístico, velhos projetos acalentados pela elite acabavam sendo retomados. A Sociedade Cultura Artística, por exemplo, recomeçou em 1943 seu plano para construção do teatro próprio para suas atividades no terreno do antigo Velódromo, onde naquele momento já estava aberta a Rua Nestor Pestana em direção à Praça Roosevelt. O novo projeto, feito pelo professor da Faculdade de Arquitetura e Urbanismo da USP (FAU) Rino Levi, acabou aprovado em 1945 pela Divisão de Política e Administração Pública da cidade, órgão criado pela nova estrutura de secretarias implementada por Cristiano Stockler das Neves, prefeito indicado pelo governador biônico ${ }^{87}$ do estado Adhemar de Barros.

\footnotetext{
${ }^{85}$ MELLO, João Manuel Cardoso de. 0 capitalismo tardio, Sãp Paulo: Brasiliense,in: ARRUDA, 2005, p.136

${ }^{86}$ SINGER, Paul. Desenvolvimento Econômico e evolução urbana, São Paulo, Cia. Editora Nacional, 1974, in: ARRUDA, Op.Cit., p. 137

87 "biônico" era a designação dada para os prefeitos e governadores indicados diretamente por chefes do executivo estatal, sem eleições diretas (pelo voto) nem indiretas (pelo parlamento). Esse método de escolha de governantes foi muito utilizado durante o Estado Novo (de 1938 a 1945), assim como na ditadura civil-miltar posterior (de 1964 a 1985).
} 
Esse processo e sua resolução mostram a burocracia da prefeitura trabalhando de forma um pouco mais descentralizada para atender os interesses construtores dessa elite, apesar de este não estar completamente alijado dos humores políticos da transição pósEstado Novo, como era talvez a intenção dos que administravam a cidade desde 1930. A criação dessa divisão no planejamento das ações e obras na cidade se deu para acomodar Sociedades Amigas de Bairro e Associações de Moradores “(...) que se multiplicaram no período se tornando importantes agentes de articulação de forças políticas do município" ${ }^{\Perp 8}$, aos quais interessa ao poder público manter como aliados em seu projeto de expansão da cidade. Também naquele momento, o Partido Comunista e movimentos autonomistas são chamados para compor os conselhos em outras regiões para marcar suas diferenças com o regime de Vargas, que perseguia tais agremiações políticas, e assim se contrabalanceava o peso das regiões mais centrais.

Em meio a todo esse cenário político, Franco Zampari e Alfredo Mesquita trataram de levar adiante a ideia de construir um teatro de uso comum dos grupos que frequentavam os encontros de domingo na casa do Zampari. A ideia teve um primeiro passo em 1945, após Zampari ter oferecido em um encontro em sua casa com a presença tambem de Alfredo Mesquita, do GTE, Décio de Almeida Prado, pelo GUT, e de Irene Smallbones, do GTE e do English Players, a construção do teatro em terrenos que possuía no bairro do Morumbi, uma região considerada "mato puro" 89 . Uma resolução que se tirou dessa reunião foi a das dificuldades de se instalar um teatro ali, porém a primeira ideia de Zampari era exatamente a de fazer o teatro “(...) em estilo veneziano, com muitos dourados e veludos, no meio de uma floresta" (LÍCIA, 2007, p. 27-8).

A região do Morumbi parecia ideal naquele momento para implementar a primeira ideia extravagante de Zampari. Bastante afastado do restante da cidade, ainda fora do planejamento urbano do município, a região era vendida por imobiliárias como um lugar para a instalação de amplas chácaras para se construir casas maiores em um estilo livre fora do padrão que viria a ser predominante nos edifícios centrais. O próprio município tinha muitas áreas a serem exploradas na região, porém não estava nos planos a instalação de qualquer equipamento público ou de transporte, mesmo após aprovação pelo Departamento de Urbanismo em 1947 dos princípios de uma lei de zoneamento para os bairros da cidade.

\footnotetext{
${ }^{88}$ FELDMAN; VILLACA, 2005, p. 109

${ }^{89}$ Segundo Alfredo Mesquita, in: GUZIK, 1986, p. 11
} 
Essa primeira reunião de articulação pela construção acabou trazendo ceticismo e certo desânimo na continuidade da empreitada, visto que a ambição de Zampari parecia desmedida para as necessidades dos amadores e as próprias possibilidades de construção. Os constantes deslocamentos de carro que seriam exigidos para ir até o local, considerando que nem todos possuíam um próprio e que transporte público até o bairro inexistia, tornariam qualquer estrutura condizente com a pretensão buscada ao teatro praticamente inviável para atores e demais trabalhadores do local.

A ideia de comprar ônibus particulares para levar e trazer público e equipe até o local pretendido ainda soaria mais cara do que a própria instalação do equipamento teatral. Naquele ano, a Light Co. São Paulo ainda controlava o transporte na cidade, disponibilizando poucos ônibus a diesel para o atendimento de locais onde não estava instalada sua rede de condução de trólebus e dos bondes. Este transporte ainda era o mais utilizado naquele momento, ainda que em vias de ser descontinuado pelo crescimento cada vez maior da cidade em direção às bordas. E apesar da tarifa padrão de mil cruzeiros do ônibus ser condizente com o ingresso mais barato de um teatro, os custos do combustível ainda eram proibitivos para se empreender tais deslocamentos com a frequência pretendida.

Além disso, a visão diversa entre Zampari e os outros potenciais empreendedores do teatro sobre o perfil do público freqüentador do tipo de teatro que pretendiam, vindo da elite ou da classe média (chamada de "pequeno burguesia" por muitos pelo fato de quererem seguir a todo custo o comportamento público da elite), mostra a dicotomia e dissociação aparentemente irreconciliável que havia entre o público do chamado "teatro de arte" em relação ao teatro dito de massa, uma situação difícil de ser avaliada e resolvida pela maneira com que se buscava conduzir o empreendimento. Alfredo Mesquita, ele mesmo filho da elite tradicional paulistana, considerava que o público geral não ia ao teatro de arte por certo comodismo com as temáticas apresentadas pelas revistas e pelo teatro de entretenimento, “(...) onde sempre se legitimam os bons sentimentos e o triunfo do bem" $"$.

${ }^{90}$ GUZIK, 1986, p. 8 
Contudo, havia também um interesse do público geral que trazia grande concorrência às apresentações de peças e companhias europeias, por se considerar que tais obras “(...) correspondiam aos seus apelos"91. Ou seja, a motivação da classe média para assistir a uma peça seguia os gostos da elite também por uma questão de concorrência social com esse grupo, pois a classe média buscava comparecer aos mesmos eventos que se pensava frequentados em peso por esta elite. Nesse sentido, o meio de transporte usado para se chegar ao teatro não era empecilho para o comparecimento - daí a insistência de Zampari em fazer o público ir ao teatro de ônibus mesmo em uma zona mais distante, pois se pensaria que a oportunidade de comparecer a um ambiente com frequência mais "selecionada" faria com que não se medissem esforços para ir até o local. Pois, na visão dele, a dita elite era já possuidora de meios de transporte individual e não deixaria de comparecer a uma apresentação de qualidade onde quer que fosse instalado o teatro.

Apesar de todas essas ponderações, o projeto pareceu enterrado na cabeça das pessoas que orbitavam em torno de Zampari. Como essa primeira reunião pareceu então desanimadora para a continuidade e efetivação do projeto do teatro, o mesmo foi deixado em compasso de espera enquanto os encontros dominicais de artistas e burgueses na casa de Zampari prosseguiam normalmente. Mas a ideia da instalação do teatro para os grupos amadores voltou a ganhar força em uma das reuniões cotidianas em outubro de 1947, por um motivo que aparentemente poderia ser colocado como banal, mas que acendeu as paixões adormecidas de todos. Nisso, o próprio Zampari fala em ter despertado a "curiosidade e o interesse criado pelo grupo de amadores" colocando aqui seus motivos para finalmente levar adiante a implantação do seu desejado teatro na cidade:

Suspeitavam que só era possível existir teatro na França, nos Estados Unidos, Inglaterra e Itália, e que no Brasil durante muitos decênios ainda teríamos que nos contentar com as companhias que nos visitavam, para ver bons espetáculos [...] $\mathrm{Eu}$, estrangeiro, me revoltei. As discussões ficaram bem violentas, e apostei que no espaço de um ano eu montaria uma companhia em São Paulo, dentro dos melhores moldes. ${ }^{93}$

\footnotetext{
${ }^{91}$ DORIA, 1975, p.5

${ }^{92}$ Entrevista a Fernando Peixoto. In: Revista Dionysos, Especial TBC. 1980, p. 62

${ }^{93}$ Idem Ibidem
} 
Apesar desse ter parecido um movimento abrupto e impensado de Zampari, o fato é que aquela ríspida discussão, a respeito dos rumos do teatro brasileiro, o impulsionou verdadeiramente na busca pela criação de uma associação que viabilizasse seus planos vindos desde 1945 de abrigar os grupos amadores em um teatro próprio. Várias possíveis leituras foram feitas a respeito do que teria consolidado a intenção inicial de Franco Zampari em empreender esse teatro.

Alberto Guzik (1986, p.12) coloca que "não permaneceu um registro das razões" que levaram Zampari a construir o teatro, ao mesmo tempo que diz que as apresentações do grupo Os Comediantes em São Paulo em 1947, e particularmente o trabalho do diretor Ziembinski com o grupo, teriam sido determinantes para sua motivação. Roberto Pompeu de Toledo (2015, p.389), por outro lado, assinala que tudo se deveu à proximidade de Zampari com Alfredo Mesquita em oposição a outros frequentadores de sua casa com interesses diversos de investimento em artes. Como Yolanda Penteado e Assis Chateaubriand, por exemplo, que penderiam mais à apreciação das artes plásticas, tendo colaborado entre si para a fundação do Museu de Arte de São Paulo (MASP) em 1947, em sala projetada por Pietro e Lina Bo Bardi na sede improvisada no prédio do Diários Associados, império midiático de Chateaubriand, nos primeiros três anos do museu $^{94}$.

Porém, ainda que seu amigo Ciccillo Matarazzo já houvesse se comprometido a colaborar com a ideia própria de Penteado, para criação do Museu de Arte Moderna, ele não deixaria seu amigo Zampari de lado se este colocasse de maneira decidida sua intenção de construir esse teatro. Desse modo, em 1948 Zampari, Ciccillo e Paulo Assumpção reuniram um grupo de duzentos empresários, e após uma exposição de suas pretensões, fundaram em conjunto com todos os presentes a Sociedade Brasileira de Comédia (SBC). A SBC, fundada no papel como uma sociedade civil não-lucrativos, apesar do intento de que houvesse alguma capitalização futura, tinha como finalidade expressada no programa de divulgação de seus Estatutos a intenção de “(...) promover, para benefício dos seus sócios e do público em geral toda espécie de espetáculos artísticos, principalmente teatrais" ${ }^{25}$. Na mesma reunião em que obteve esse apoio para sua fundação, a SBC empossou a sua primeira diretoria:

94 Lina Bo Bardi foi então convidada por Chateubriand para projetar o prédio definitivo do MASP, inaugurado em 1950 na Avenida Paulista, onde permanece até hoje. Cf. em ARRUDA, 2001, p. 112 ${ }^{95}$ LÍCIA, 2007, p. 30 


\begin{tabular}{|c|c|c|}
\hline \multicolumn{3}{|c|}{$\begin{array}{l}\text { COMPOSIÇÃO JURÍDICA - 1 a DIRETORIA - } 1948 \\
\text { SOCIEDADE BRASILEIRA DE COMÉDIA (SBC) }\end{array}$} \\
\hline \multicolumn{3}{|c|}{ Presidente de Honra: Francisco Matarazzo Sobrinho (Ciccillo) } \\
\hline \multirow{3}{*}{$\begin{array}{l}\text { Secretários: } \\
\text { Abílio Pereira de Almeida } \\
\text { Carlos Vergueiro } \\
\text { Tesoureiro: Franco Zampari }\end{array}$} & \multirow{2}{*}{\multicolumn{2}{|c|}{$\begin{array}{l}\text { Presidente: Paulo Álvaro Assumpção } \\
\text { Vice-Presidente: Adolfo Rheingantz }\end{array}$}} \\
\hline & & \\
\hline & \multicolumn{2}{|c|}{$\begin{array}{l}\text { Consultoria Jurídica: Antonio Caio da Silva Jr } \\
\text { Nelson e Paulo Cândido Motta }\end{array}$} \\
\hline \multicolumn{3}{|c|}{ Conselho Consultivo: } \\
\hline $\begin{array}{l}\text { - Alfredo Mesquita } \\
\text { - Clóvis Graciano } \\
\text { - Décio de Almeida Prado }\end{array}$ & $\begin{array}{l}\text { - Nicanor Miranda } \\
\text { - Aldo Calvo } \\
\text { - Ruy Affonso Machado }\end{array}$ & $\begin{array}{l}\text { - Madalena Nicol } \\
\text { - Vicente Ancona } \\
\text { - Enzo Cajone }\end{array}$ \\
\hline
\end{tabular}

Apesar de ser fundada como uma sociedade de fins não-lucrativos, portanto que não almejaria um retorno imediato para seus investidores, houve por certo um trabalho de convencimento das possibilidades do empreendimento a longo prazo para os envolvidos, ainda que de modo simbólico. Zampari conseguiu o apoio dos presentes ao colocar esse investimento não como uma doação benemérita de filantropo, mas como um mecenato cultural baseado no fortalecimento institucional de uma empresa capitalista de um setor emergente, porém respaldada por pessoas de sucesso em seu meio empresarial. Ou seja, o modelo administrativo para o empreendimento teria sido tão ou mais importante para a aprovação do projeto do que qualquer plano artístico.

O comprometimento obtido entre a burguesia com a causa da construção do teatro, mesmo que a dedicação de muitos deles já tivesse se expressado também em outras áreas artísticas, reforça a ideia de que ela no período pós-Estado Novo pareceria ter definitivamente assumido “(...) a proeminência (do investimento) no âmbito da cultura de São Paulo" (ARRUDA, 2005, p. 143). Isso era algo buscado por essa elite desde a Semana de Arte Moderna de 1922, ainda que expressa em iniciativas isoladas desde então. Especialmente na comparação com a política de Vargas de subvenção e certa intervenção estatal, que chegou a São Paulo mas se deu principalmente na capital federal, a maneira como a iniciativa privada buscava uma ação ativa no meio cultural de São Paulo pareceu alvissaeira, sobretudo no meio teatral.

As condições para o estabelecimento da elite que se lançou ao mecenato cultural nos anos 1940 se deram pela confluência do poder econômico de imigrantes ascendidos que buscavam se diferenciar socialmente junto a pessoas que deles se aproximavam 
para produzir cultura. No nascente capitalismo de mercado brasileiro, tornou-se comum entre os imigrantes donos de certo capital durante o século XX investirem em bancos e no transporte ferroviário, formando companhias de capital aberto com ações na Bolsa de Valores que se davam melhor que as empresas de imigrantes organizadas em sociedades limitadas familiares (LOVE, 1982; apud ARRUDA, 2005, p.139). Essa aproximação com outras possibilidades de poder, inclusive o político (Ibid., p.142), gerava também a oportunidade de ganho de capital intelectual, seja frequentando ou investindo em eventos e locais culturais.

A cultura de mecenato nos anos 1940, em contraste com os anos de 1920 e 30, adquiriu esse papel de competição entre os possíveis agentes investidores, da mesma forma que a frequência nos locais também se tornou mais concorrida em certos momentos. Elementos da classe média, considerados por Sergio Miceli “parentes pobres da oligarquia" (2012, p.111) não por serem efetivamente pobres mas por estarem longe das instâncias de poder se sentiam “(...) incentivados pelas oportunidades de aquisição de capital escolar e cultural que dariam acesso preferencial àquelas posições profissionais conquistadas pelo capital de relações sociais" (MICELI, idem ibidem) ${ }^{96}$. Nesse sentido, há de se destacar a inserção da classe média universitária nesse ambiente de busca de maior capital cultural, como mediadora e partícipe na mudança das relações estabelecidas entre a elite e o meio cultural, tanto como espectadora como no trabalho dos grupos universitários a dar respaldo às suas intenções de grandeza.

Porém, não havia uma substituição da burguesia mas uma acomodação desta junto à elite tradicional, isso tanto com os novos ricos imigrantes como com a elite agrária que vinha até São Paulo investir sua fortuna ganha nas fazendas. Essa elite rural detinha outra tradição, mais facilmente assimilada pela cidade que a elite imigrante. A convivência entre os entes citados se mostrava evidente nos espaços de lazer, como era a própria casa de Zampari para os que a frequentavam aos domingos em seus encontros em prol da arte, assim como outros promoviam eventos semelhantes para diversos interesses. Peguemos dois exemplos para ilustrar como eram estruturadas essas relações entre os atores sociais da elite na primeira metade do século XX, e as diferentes maneiras como investiam suas fortunas.

\footnotetext{
${ }^{96}$ MICELI, Sergio. Intelectuais brasileiros. In: O Que Ler na Ciência Social Brasileira (1970-1995). Volume II-Sociologia. São Paulo: ANPOCS/Editora Sumaré/CAPES, 2012, p. 109-145. Disponível em <http://anpocs.org/index.php/o-que-ler-1970-1995/volume-ii-sociologia/641-intelectuaisbrasileiros/file> Acessado em 21 de julho de 2019
} 
Uma parte da família Penteado fez fortuna com fazendas em Santa Cruz das Palmeiras e chegou a São Paulo anos antes dos pais de Yolanda Penteado. Essa parte da família, cujo patriarca era o então industrial Antônio Álvares Penteado, foi uma das introdutoras da cultura do carro na cidade, sendo tambem das primeiras a possuírem um automóvel por volta de $1900^{97}$. Sua fama de misantropo o fez construir várias iniciativas formativas para a área de comércio $^{98}$ além do Teatro Sant'Anna em 1900, usado pelos grupos filodramáticos. Penteado também oferecia encontros sociais em sua vila particular em Higienópolis e convidou para um deles em 1908 um francês de nome Claude Lesdain que havia acabado de fazer uma série de exibições automobilísticas.

$\mathrm{Na}$ recepção a Lesdain, estavam presentes pessoas proeminentes da sociedade paulistana como Ramos de Azevedo, além de “(...) um imigrante graúdo que começava a ser aceito nas altas rodas, o conde Alexandre Siciliano", 99 industrial e banqueiro. A competição entre eles e o desafio dos presentes aos feitos de Lesdain se materializaram quando naquele mesmo ano ajudaram a fundar o Automóvel Clube de São Paulo, promovendo corrida pelo chamado "circuito de rua de Itapecerica", saindo e chegando no Parque Antártica, estádio então pertencente à Companhia Antarctica mas aberto ao público geral. Tal corrida foi então vencida pelo filho de Antônio Penteado, Silvio. ${ }^{100}$

Yolanda Penteado veio da cidade de Leme a São Paulo com os pais em 1910, mas era próximo de Antônio Álvares, por seu tio Inácio ser irmão do patriarca. Apesar de ter outra familiar bastante envolvida com as artes - Olívia Guedes, esposa de Inácio, tinha grande amizade com muitas figuras do movimento modernista, como Anita Malfatti, Tarsila do Amaral e Heitor Villa-Lobos -, Yolanda Penteado tinha ligação distante com o modernismo através de seu casamento com o arquiteto Jayme da Silva Telles de 1921 a 1934. Mesmo sendo ele um dos fundadores da Sociedade Pró-Arte Moderna, ainda era considerado por demais "novo" em relação a outros como Rino Levi, com formação no exterior ${ }^{101}$.

\footnotetext{
${ }^{97}$ POMPEU DE TOLEDO, 2015, p. 70

${ }^{98}$ A Escola de Comércio Álvares Penteado se tornaria a Faculdade FAAP, ao aumentar sua oferta de cursos para áreas administrativas e de finanças, entre outras opções.

99 Ibid., p. 81

100 Ibid., p. 83

${ }^{101}$ Cf. em FREITAS, Maria Luiza de. Um brasileiro na arquitetura moderna de São Paulo: Jayme da Silva Telles e o Projeto "Ford" (1925-1931). in: Docomomo Brasil (plataforma online). Disponível em: <http://docomomo.org.br/wp-content/uploads/2016/01/Maria-Luiza-de-Freitas.pdf> Acessado em 21 de julho de 2019
} 
Posteriormente, Yolanda Penteado pode expressar protagonismo e envolvimento maior com as artes e com alguma forma de mecenato, por sua atuação junto com Assis Chateubriand, com quem tinha amizade desde sua adolescência, na aquisição de muito do que seria o acervo que originaria o MASP. Nesse sentido, o relacionamento iniciado por Penteado com Ciccillo Matarazzo, que resultou no casamento deles em 1947, influiu muito mais na capacidade dela seguir buscando colaborar mais com o MASP do que em um papel de subserviência. Além da colaboração de Yolanda Penteado na curadoria das obras, foi importante o papel de Nydia Lícia, que trabalhava como assistente de Pietro Maria Bardi enquanto era atriz do GTE, no convite a Lina para colaborar na instalação do MASP, e posteriormente na sua constituição definitiva na Avenida Paulista ${ }^{102}$.

Essas histórias distintas de dois ramos da família Penteado ilustram alguns dos fenômenos típicos das relações sociais da elite paulistana na primeira metade do século XX. O padrão de mecenato o qual Álvares e Yolanda Penteado reproduziam em seus momentos históricos eram os mais característicos da época em que atuaram. Para Álvares, investir no que era seu entretenimento - os carros e o teatro - tinha o mesmo valor do seu investimento no campo da formação em sua Escola de Comércio. Mas o que parecia ser uma ação para a cidade tinha por demais uma função aristocratizante ${ }^{103}$ de perpetuação do seu nome sendo reconhecido como um benemérito acumulador.

Além do mais, o investimento nessas áreas por parte de Álvares Penteado ainda era secundário em relação ao dinheiro posto no seu trabalho ou na manutenção das fontes de renda alternativas dos bancos ou outros investimentos, pois muitos industriais e cafeicultores também eram ávidos rentistas, capitalizando ações na Bolsa de Valores para que suas empresas tivessem ainda mais lucro. Ao mesmo tempo, dava-se muita importância à manutenção do status quo em relação à continuidade do legado familiar, contrariando alguns dos valores de maior abertura e liberalidade econômica que o capitalismo emergente no país na primeira metade do século XX pregava como mais enriquecedores naquele momento.

\footnotetext{
${ }^{102}$ Cf. na p. 73

${ }^{103}$ GALVÃO, Maria Rita. Burguesia e Cinema: O Caso Vera Cruz. Rio de Janeiro: Civilização Brasileira, 1981. in: ARRUDA, 2005, p. 142
} 
No caso de Yolanda Penteado, o papel que lhe esperado na sociedade, considerado secundário apenas por ser mulher, a deixaria mais distante das decisões de poder sobre ações artísticas. De certo modo, por um tempo ela poderia ter se sentido compelida pela família a buscar melhores conjunções maritais para que pudesse conseguir uma boa posição pra si e todos ao seu redor. Além disso, sua separação do primeiro matrimônio a colocou numa situação de pressão sem que houvesse uma garantia de continuidade de seu legado em relação aos padrões exigidos para a sociedade da época. Certamente ela conseguiu superar isso por seu talento e bom gosto para as artes, além das boas relações construídas pela sua posição.

Os locais culturais que ela então frequentava se tornavam refúgio e oportunidade assim como o eram para tantos artistas e intelectuais que buscavam estabelecer contato direto com alguém de importância, especialmente se fosse no papel de se tornarem um possível mecenas ${ }^{104}$, para si ou em sociedade. Yolanda Penteado estabeleceu seus contatos e exerceu tal papel no fim dos anos 1940 não apenas na companhia de outros homens, no caso Assis Chateaubriand e Ciccilo Matarazzo, mas tomando seu próprio protagonismo. Sendo assim, mesmo com alguma contribuição na efetivação dos empreendimentos com os quais colaborou em sua construção, inclusive com investimentos em quadros para os museus que planejava instalar, sua contribuição somente pareceu se efetivar de fato por ela estar junto a essas pessoas.

Um ponto comum nas duas trajetórias retratadas, de Álvares e Yolanda Penteado, foi a valorização em determinado momento do elemento estrangeiro especializado em detrimento da formação nacional, tanto no caso da comparação entre Rino Levi e Jayme Telles na arquitetura como, no caso de Álvares Penteado e Claude Lesdain, na competição gerada pelo confronto das experiências de ambos em uma dada atividade. No primeiro caso, o escanteamento do profissional nacional não soava condizente com os valores pregados pelo movimento modernista, apesar de muitos dos que fizeram parte dele terem tido parte importante de sua formação no estrangeiro. Essa atitude parecia consonante com a maneira como a especialização superior foi considerada por muito tempo como precária no país, numa visão que foi lentamente sendo desconstruída pelos anos 1940 com a fundação da USP e os intelectuais por ela formados.

${ }^{104}$ ARRUDA, 2005, p.140 


\section{A “SOCIEDADE BRASILEIRA DE COMÉDIA"}

㰓

rirea de dois anos, un zrupo de apre riadores de teatro. liderado pelos senhores Franriere Matarazzo Sohrinho, Paulo de Anumpsav, e France Zaupari. iniciou um movi. mento para a orzanizaçảo. em Sáo Paulo. de uma Sociedade cujo único objetivo föse prestar todo apóio e assisténeia ao desenvolvimento. no nowo meio, do gústo pelo teatro.

$$
\text { -.. }
$$

Come resultado dése mosimento, sem de se constituir, definitivameute, a "Sucielade Brasileira de Comridia" - soriedade rivil de fin nảo cronó. micus - cuja finalidade. exprena nos Estatutus é promover. para beneficio dos seus ricios e do pú. blico eu geral, tóda opécie de eppetáculo, artiti. cos, principalmente teatrais.

$$
\text { -. }
$$

O primeiru parno da Sociedade Branileira de Comrilia foi entrar em contarto rom os principais grupos de amadore, de teatro evi-tentes ein Sao

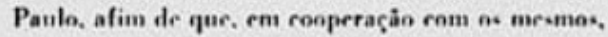
pudene dende logo iniciar a construşào de un moderno teatro de comédia. dotado de todos os requi. sitos da téenica moderna, em matéria de eletriri dade, acústica, visibilidade, e aparelhamento cénico.

$$
\text { -.. }
$$

Concluido, sati,fatoriamente ène, entendimen10. ji foram ataradas as obras do futuro teatro da Suciedade Brasileira de Comédia - e dor amadores de Sào Paulo - à Rua Major Dingo. N, 315. ..

Tratando-se de empreendimento de täo grande sultu. destinado a marcar época no deseavolvi. mento do teatro no Brasil. necessário se faz, para que - eja plenamente realizado, o auxilio e o apoiio de todos os paulistas amigos de teatro.

$$
\text { -.. }
$$

Fira aqui regitrado o aprilo da Sociedade Bra. sileira de Comédia: - a partir déte momento. e atŕ que srjam pazas a* desprsa* de con-truçảo, tỏda a renda don espetaculos realizado, sob o patrocinio da S. B. C. será aplirata no "Teaten Brasileire de Comédia" - yue o púl,liro paulittano comparesa a rues ruprtárulos, r estará contriluindo para dotar Sào Paulo de un moderne leatro, que será usado ex. clu-ivamente para o hem do público. e da Arte...

Imagem 9 - Apresentação da Sociedade Brasileira de Comédia em programa de "À Margem da Vida", de Tennessee Williams, apresentado pelo GTE no Teatro Municipal em 10 de agosto de 1948 (LÍCIA, 2007)

Nessa conjunção de fatores que fez com que a elite paulistana se sentisse mais confortável e animada a investir em bens culturais duradouros para a cidade, haviam considerações a serem ponderadas para se chegar à concretização desse movimento, relacionados a como o mecenato cultural se comportava no momento. A tabela abaixo

\begin{tabular}{|c|c|c|c|c|}
\hline \multicolumn{5}{|c|}{ RAZÕES ELENCADAS PARA INVESTIMENTO NO TEATRO DA SBC } \\
\hline $\begin{array}{l}\text { Atração do } \\
\text { investidor por } \\
\text { uma expressão } \\
\text { artística } \\
\text { (Teatro) }\end{array}$ & $\begin{array}{l}\text { Natureza dos } \\
\text { investimentos } \\
\text { (de risco, sem } \\
\text { lucro aparente } \\
\text { a curto prazo) }\end{array}$ & $\begin{array}{l}\text { Lógica } \\
\text { empresarial } \\
\text { (garantias de } \\
\text { viabilização e } \\
\text { manutenção) }\end{array}$ & $\begin{array}{l}\text { Respaldo } \\
\text { institucional } \\
\text { (suporte de } \\
\text { entidades da } \\
\text { universidade } \\
\text { sociedade civil) }\end{array}$ & $\begin{array}{ll}\text { Equipe } & \\
\text { qualificada de } \\
\text { executivos } \\
\text { (diretor geral } \\
\text { artístico) } \\
\text { executores } \\
\text { (atores/técnicos) }\end{array}$ \\
\hline Cultura & Aposta & Administração & Apoio & Profissionalismo \\
\hline
\end{tabular}
ilustra uma ideia de quais fatores preponderantes no modo de ação empreendedor do período teriam sido determinantes para a escolha de investimento no projeto de Franco Zampari para o teatro: 
Desse modo, após ter conseguido a atração da elite para investir numa expressão artística apreciada por parte significativa dela, mesmo naquele momento ainda subfinanciada e portanto aquém do potencial de alta qualidade não plenamente atingido; de auferir o respaldo dado por elementos da universidade que fariam esse projeto acontecer a contento; de mostrar a natureza dos investimentos ainda que com risco de se perderem ou de não derem lucro; e de convencer de sua viabilização econômica em uma lógica empresarial, o último passo para a concretização desse teatro era a busca pelos profissionais que ocupariam o teatro. Nesse caso, ainda que a visão sobre a formação brasileira estivesse mudando, os estrangeiros, quer fossem atores, professores ou demais profissionais, ainda eram vistos por muitos como os únicos capazes de exercer o ofício com técnica irreparável.

Através do seu processo de maior crescimento e concentração populacional, a cidade de São Paulo ao mesmo tempo que experimenta um fenômeno semelhante a várias outras metrópoles mundiais estabelece a sua própria marca sociocultural. Dentro do contexto geral de caldeamento/miscigenação da população brasileira durante os séculos - bastante considerada por pensadores da época como Gilberto Freyre e Sergio Buarque de Hollanda -, houve novos fluxos migratórios que se somaram aos que haviam chegado como mão-de-obra desde o final do século XIX a ocupar as fazendas do interior e as indústrias e serviços da capital. Esses novos fluxos ocasionados em grande parte pela Segunda Guerra Mundial trouxeram outros imigrantes fugidos dos países do Eixo ou de outros por eles atacados, acabando por contribuir com a construção de uma nova constituição cultural do Brasil, e em particular da cidade de São Paulo, que pintava a “(...) universalidade abstrata (com) que a transformação do tecido cultural culmina com a organização de instituições de peso" (ARRUDA, 2001, p.116).

Isso significa que muitos desses imigrantes vinham para o Brasil por questões específicas realacionadas à sua atuação, seja política ou cultural, fossem perseguidos pelos governos de seus países ou fugidos do estrangulamento que viam na expressão de suas atividades. Dessa forma, o país teve contato com artistas como Ziembinski, vindo da Polônia ao Rio de Janeiro a dirigir Os Comediantes desde a montagem de "Vestido de Noiva", de Nelson Rodrigues, em 1943 até a transição do grupo para um regime profissional. O mesmo foi feito por Ruggero Jacobbi, que veio ao Brasil em 1946 movido pela curiosidade com o teatro nacional que se manifestou em estudos a respeito 
dos amadores nos anos 1940. Ele considerava o movimento brasileiro muito forte, além de seguir as mesmas necessidades de renovação do teatro italiano experimentava naquele momento, “(...) instituindo a direção teatral como fator de construção de uma manifestação cultural em substituição ao espetáculo como entretenimento"105.

Num primeiro momento, ao ter ficado "muito entusiasmado com os espetáculos

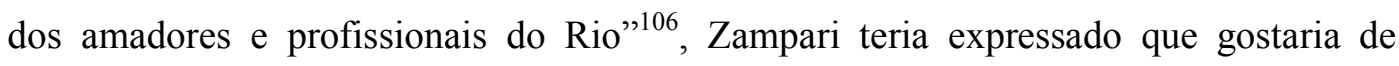
convidar Ziembinski para se juntar à companhia, após Os Comediantes terem dissolvido o grupo em 1947. Mas as dificuldades na implementação do projeto do teatro o teriam demovido da ideia. Nesse instante, a questão de se procurar os profissionais estrangeiros como garantidores do projeto do teatro não parecia mais tão infalível. Zampari confiou no comprometimento dos grupos que acompanhavam Alfredo e Décio - este crítico de teatro de $O$ Estado de S. Paulo -, ainda que a atividade deles fosse então oscilante. ${ }^{107}$

O novo passo para a implementação do projeto se deu com o local a ser finalmente instalado o teatro. Sobre isso, Nydia Lícia, então atriz do GTE, tendo acompanhado desde o início o movimento em prol do teatro dos amadores, relata aqui a importância de Hélio Pereira de Queiroz, então no GTE, no processo de busca já em 1948 do lugar ideal para a concretização do desejo de Franco Zampari:

Hélio indicou um prédio na Rua Major Diogo, que havia sido um laboratório farmacêutico e, antes disso, a sede de uma organização fascista, a Unione Dopolavoro Italiana (disfarçada de União Desportiva Italiana), e agora estava vazio e parecia perfeitamente adequado para uma reforma. Imediatamente trataram de alugá-lo e as obras começaram. ${ }^{108}$

A Sociedade Brasileira de Comédia em um primeiro momento alugou o prédio em estilo art noveau da Rua Major Diogo pelos quatro anos seguintes a partir de julho de 1948, com Ciccillo como seu fiador, esperando que o edifício pudesse permanecer como teatro e vingar como empreendimento cultural. Porém, Zampari estabeleceu um prazo menor para isso que o tempo do contrato inicial. Ele teria dado dois anos para saber se o grupo de amadores reunidos na companhia reuniria condições para se manter,

\footnotetext{
${ }^{105}$ RAULINO, 2002, p.41

${ }^{106}$ Abílio Pereira de Almeida e Miroel Silveira colocaram essas afirmações em uma série de relatos históricos concedidos para registro do SNT, in: GUZIK, 1986, p.11-2

107 o GUT de Décio só tinha em repertório "as três peças que realizou desde a sua fundação" e Alfredo Mesquita se preparava para um novo projeto (GUZIK, Op. Cit., p.11)

${ }^{108}$ LíCIA, 2007, p.29
} 
considerando então a possibilidade de devolver o prédio nesse prazo. A negociação foi feita assim para não entrar no decreto final do governo Vargas sobre construção de teatros, que obrigaria que ele permanecesse com esse fim por quinze anos.

O dono do local do edifício também não ficaria satisfeito em ver mais um locatário ir embora tão rápido. Porém, não havia maiores registros dessa ocupação prévia. O próprio nome da organização fascista que alegadamente ocupou o local, Unione Dopolavoro, não diferia muito das associações dos filodramáticos. Afinal, os fascistas também sabiam trabalhar a linguagem teatral para seus intentos de propaganda do regime ${ }^{109}$, além de pelo nome brasileiro escolhido se depreender que seus fundadores também tinham a intenção de se tornarem um clube social - na mesma região funcionava uma das filiais da fábrica de calçados Scatamacchia, baseada em Franca, noroeste do estado. Mas relatos do próprio Zampari atestam que no momento em que se fechou o contrato com o dono do local, o Sr. Ary Freitas de Camargo, somente uma garagem estava em pleno funcionamento ${ }^{110}$.

O Sr. Ary Freitas de Camargo aparentemente era um homem da classe média que não frequentava círculos intelectuais, mas buscava encontros sociais em locais típicos da elite. Fora o registro de seu nome como proprietário do local onde seria instalado o teatro de Franco Zampari, seu nome foi encontrado durante os anos $1920 \mathrm{e}$ 1930 como sócio frequentador de muitos clubes esportivos, como o Paulistano, o São Paulo e o Estudantes Paulista, todos considerados de alta classe. Neles, o Sr. Camargo participava de atividades competitivas de ping pong ou como membro de conselhos internos que acompanhavam os times de futebol desses clubes. Considerando o fato de que o espaço onde foi instalado o teatro dos amadores foi alugado por ele à SBC, portanto com ele tendo ainda algum vínculo com a mesma após sua instalação, não consta registro que o Sr. Camargo tenha tido algum envolvimento maior no empreendimento, nem como frequentador nem como parte de algum conselho interno ou mesmo como sócio da SBC.

Nydia Lícia então chama a atenção para a importância do trabalho de um diretor estrangeiro que se associou ao projeto desde seu início: o italiano Aldo Calvo, que sendo arquiteto de formação sabia as questões prementes na construção de um teatro:

\footnotetext{
${ }^{109}$ Cf. em RAULINO, 2002, p.18-32

${ }^{110}$ GUZIK, 1986, p. 13
} 
A sorte de Zampari foi que naquela época já estava em São Paulo um dos maiores cenógrafos e técnicos da Itália: Aldo Calvo. Foi ele que orientou os engenheiros (José Augusto Bellucci e equipe da Camargo Pacheco S/A) e operários encarregados da reforma, desenhou os refletores que a Metalúrgica Matarazzo construiria, cuidou do palco, no qual instalou dois discos giratórios, e proporcionou à cidade um teatrinho de visibilidade e acústica perfeitas. Menos de três meses mais tarde, o TBC estava pronto para estrear. ${ }^{111}$

Aldo Calvo era cenógrafo do teatro Scala de Milão e da Ópera de Roma, os dois mais prestigiados teatros italianos, e teve sua chegada noticiada pelo jornal A Noite em outubro de 1947 como “(...) contratado para trabalhar na decoração dos Teatros Municipais do Rio e de São Paulo para 1948”. Além disso, acabou sendo contatado por Franco Zampari para dirigir o departamento técnico do seu teatro, onde com sua ampla visão técnica foi reponsável pela implementaçãodo projeto de Zampari da maneira que queria, com oficinas de cenografia, carpintaria e cenotécnica, dando com a entrada de tal profissional estrangeiro o respaldo defintiivo para apresentar à Sociedade a ideia de que finalmente seriam estes os passos finais para se fundar uma companhia teatral a partir dos grupos amadores e colocá-la em um teatro próprio da melhor maneira.

Antes da efetivação de Calvo, essa insistência na contratação de um estrangeiro para a implantação do teatro já havia deixado de ser unânime. Quando foi apresentada a proposta de reforma do espaço escolhido para o teatro, Rino Levi, que já trabalhava na implantação do teatro Cultura Artística,foi chamado por Ciccillo Matarazzo para fazer do locala sede do Museu de Arte Moderna (MAM). Eles e Pietro Maria Bardi, mecenas então diretor do museu, propuseram que a obra do MAM seria também feita através da $\mathrm{SBC}$, com o teatro se tornando anexo ao museu. Contudo, houve muitos litígios quanto à viabilidade desse projeto, principalmente por parte de Zampari, que acabaram por afastar Levi de sua implementação e separar a SBC de qualquer responsabilidade em bancar a obra do MAM, levando o museu a ser alocado provisoriamente em uma sala da empresa de Matarazzo, e posteriormente em andar de edifício da Rua Sete de Abril. ${ }^{112}$ Essa recusa na adequação do projeto do teatro acabou abrindo uma possibilidade que logo mais acabou sendo bem aproveitada.

\footnotetext{
${ }^{111}$ LÍCIA, 2007, p.30

${ }^{112}$ GUZIK, 1986, p. 14
} 
Isso porque Alfredo Mesquita preparava a abertura do seu projeto da Escola de Arte Dramática (EAD) enquanto ensaiava o grupo próprio com o qual pretendia entrar no projeto de Zampari para o teatro da SBC. Em 3 de maio, deu-se a apresentação de abertura da escola por Paschoal Carlos Magno no auditório da Biblioteca Municipal (hoje Mário de Andrade), cedido por Sergio Milliet, então diretor da Divisão de Bibliotecas do Departamento de Cultura e integrante da SBC. Seu primeiro local de aulas foi o Externato Elvira Brandão na Alameda Jaú, cedido por Dona Aída Brandão Caiubi “(...) com carteiras infantis e condições um tanto precárias." ${ }^{113}$ Suas aulas, com professores como o próprio Alfredo Mesquita, Décio de Almeida Prado e Cacilda Becker, tinha formação técnica e cultural acima da média, fazendo os exames e a administração do local serem mais rígidos que de costume.

Uma das regras mais importantes para a excelência dos alunos pretendida por Alfredo Mesquita era de que só poderiam se tornar profissionais após a conclusão do curso, o que conferia especial atenção aos exames finais. Estes exames sempre eram liderados por uma banca de professores e atores, ainda que nenhum deles fosse pago nesse primeiro ano, trabalhando pela causa do teatro brasileiro. Mesquita era assim zeloso com sua criação não apenas por fazê-la funcionar com seus próprios recursos, mas por estar certo de que "o movimento amador tenderia ao profissionalismo" ${ }^{114}$ logo mais. E com a efetivação da criação do teatro da SBC, Alfredo se mostrou ainda mais entusiasmado.

Enquanto ensaiava "À Margem da Vida", de Tennessee Williams, com seu grupo que juntava egressos tanto do GTE - Nydia Lícia, Abílio Pereira de Almeida como da primeira turma da EAD - Clóvis Graciano, artista plástico, que participou do GUT e trabalhou como cenógrafo -, via surgir um misterioso ensaio no jornal O Estado de S. Paulo assinado por Bettino falando dos teatros que vinham sendo condenados pela demolição causada pelo crescimento da cidade, e anunciando o teatro que estava para ser aberto aos “(...) três grupos amadores existentes na Paulicéia” enquanto também permitia e incentivava “(...) a cessão por aluguel a companhias estrangeiras em benefício financeiros à Sociedade que está promovendo a construção e (dele) se tornará proprietário." 115

\footnotetext{
${ }^{113}$ GÓES, 2007, p. 187

${ }^{114}$ SILVA, 1989, p.52

${ }^{115}$ LÍCIA, 2007, p. 32
} 
Tentava-se de toda forma viabilizar financeiramente a efetivação do teatro, ainda que desde julho de 1948 as reformas na Rua Major Diogo corressem bem. A apresentação da peça ensaiada por Alfredo Mesquita aconteceu em 10 de agosto de 1948, no Teatro Municipal, e teve toda a sua renda (a segunda maior de uma montagem dos amadores paulistas $)^{116}$ revertida para “(...) contribuir na construção do Teatro Brasileiro de Comédia”. Essa era a primeira vez que o nome do teatro da Sociedade Brasileira de Comédia a ser inaugurado era mencionado, com a sua sigla - TBC, em alusão ao SBC da Sociedade - descrita no programa junto a uma apresentação da carta de intenções da Sociedade e dos grupos coligados a ela ${ }^{117}$. Ainda assim, o mistério do texto no jornal em conjunto com essa apresentação pareceu ter sido bom para fustigar a curiosidade alheia.

\section{0 “TEATR 0 BRASILEIR 0 DE COMÉDIA”}

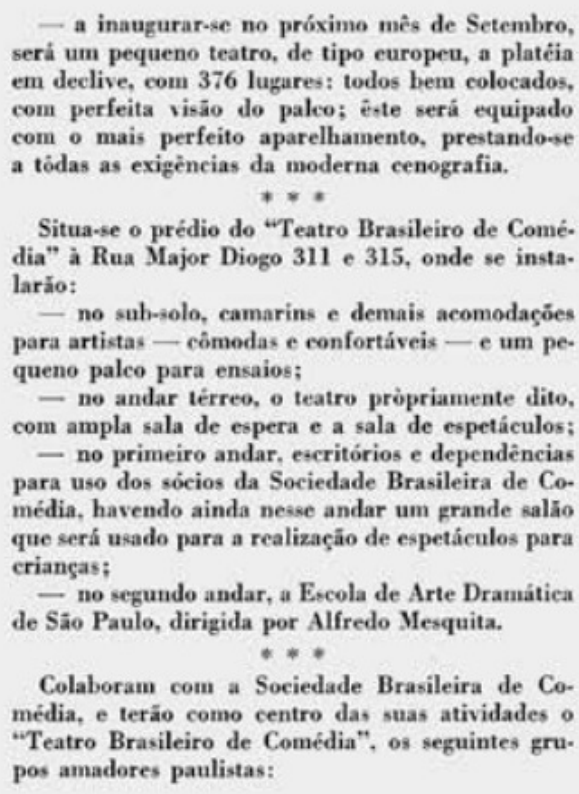

- a inaugurar-se no próximo mês de Setembro, será um pequeno teatro, de tipo europen, a platéia $\mathrm{em}$ declive, com 376 lugares: todos bem colocados, com perfeita visão do palco; êtote será equipado com o mais perfeito aparelhamento, prestandose a tódas as exigèncias da moderna cenografia.$$
* * *
$$

Situa-se o prédio do "Teatro Brasileiro de Comé. dia" à Rua Major Diogo 311 e 315, onde se insta. laráo:

- no sub-solo, camarins e demais acomodaçóes para artistas - cômedas e confortáveis - e um pequeno palco para ensaios;

- no andar térreo, o teatro pròpriamente dito. com ampla sala de espera e a sala de espetáculos;

- no primeiro andar, escritórios e dependências para uso dos sócios da Sociedade Brasileira de Comédia, havendo ainda nesse andar um prande salăo que será usado para a realizaçăo de espetáculos para crianças;

- no segundo andar, a Escola de Arte Dramática de São Paulo, dirigida por Alfredo Mesquita.

$$
* *
$$

Colaboram com a Sociedade Brasileira de Comédia, e teráo como centro das suas atividades o "Teatro Brasileiro de Comédia", os seguintes gru. pos amadores paulistas:

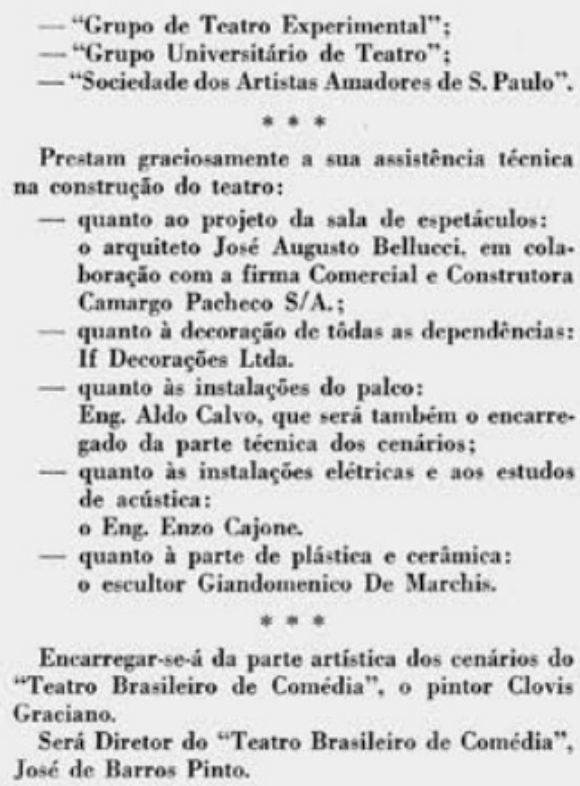

Encarregar-se-â da parte artística dos cenários do "Teatro Brasileiro de Comédia", o pintor Clovis Graciano.

Será Diretor do "Teatro Brasileiro de Comédia", José de Barros Pinto.

Imagem 10 - Apresentação do TBC em programa do GTE no Teatro Municipal em 1948 (LÍCIA, 2007; Cf. na p. 79)

\footnotetext{
${ }^{116}$ Somente perdendo para "Pif-Paf", de Abílio Pereira, montada pelo GTE, in: GÓES, 2007, p. 196

${ }^{117}$ Por algum motivo, o autor misterioso do texto do jornal atribuído a Bettino para apresentar o novo teatro da SBC citou apenas "três grupos amadores que encenavam na capital", porém sem citá-los. No programa de "À Margem da Vida" no Municipal, falava-se do GUT e do GTE junto aos Artistas Amadores de Madalena Nicol e Paulo Autran, apesar dos English Players também participarem das primeiras reuniões para construção do projeto do teatro e terem sessões no novo teatro em seus primeiros momentos. Por essa apresentação, pode-se inferir que o autor do texto ao jornal tenha sido Alfredo Mesquita, pois Décio de A.Prado estava em O Estado de S. Paulo como crítico de teatro desde 1946.
} 
Com o sucesso da apresentação do teatro e a consolidação da primeira turma da EAD - ainda que tendo formado metade dos trinta alunos que nela se inscreveram -, Alfredo Mesquita seguia uma verdadeira peregrinação por órgãos públicos e privados para tentar garantir subsídios para a continuidade da escola. Mas com a confirmação de que o projeto de Zampari para o TBC não teria as modificações pensadas por Rino Levi, Zampari achou por bem ajudar o amigo após o momento que o teatro fosse inaugurado, cedendo a ele o segundo andar do prédio “(...) inicialmente por um aluguel módico, e depois de graça” (GÓES, 2007, p. 190) pelo tempo que achasse necessário. Alfredo aceitou e o segundo semestre da escola começou no novo endereço.

Para os alunos, essa nova disposição não parecia apenas mais confortável quanto ao espaço, mas também quanto aos seus deslocamentos até o local. As aulas eram sempre à noite, das $20 \mathrm{~h}$ às $22 \mathrm{~h} 30$, e o Jardim Paulista ainda era bastante difícil para se chegar da Avenida Paulista ou da Rua Augusta, por suas ladeiras cansativas para quem já vinha de um trabalho extenuante durante o dia. Na Bela Vista, podia-se pegar da Praça da Bandeira o bonde $n^{\circ}$ 5, desde 1946 gerido pela empresa pública CMTC, e descer na Rua São Domingos ou Conselheiro Ramalho a um quarteirão do "teatroescola" na rua Major Diogo. Ainda que o bonde da CMTC fosse mais caro que nos tempos da Light (quinhentos réis, contra duzentos até 1946), o que motivou uma série de protestos violentos da população em $1947^{118}$, o transporte próximo também era bom para o público que não fazia questão, ou não tinha condições, de chegaraté lá de carro. $\mathrm{O}$ fato de o teatro também não estar na rua do bonde faria quem usava do carro pará-lo com maior tranquilidade na rua.

E dessa forma o TBC foi finalmente inaugurado em 11 de outubro de 1948, com uma sessão de gala de "A Voz Humana", de Jean Cocteau, em apresentação solo da atriz francesa Henriette Morineau - pois, apesar do ecletismo dos fundadores, que seguiam o teatro italiano, norte-americano e britânico, o teatro francês ainda era a grande referência de "bom gosto" ao público médio - seguida de uma apresentação pelo GTE de "A Mulher do Próximo", peça de Abílio Pereira onde Cacilda Becker foi

${ }^{118}$ Cf. em DUARTE, Adriano Luiz. O "dia de São Bartolomeu" e o "carnaval sem fim": o quebra-quebra de ônibus e bondes na cidade de São Paulo em agosto de 1947, in: Revista Brasileira de História, v.25, n.50, São Paulo, jul./dez. 2005. 
incorporada ao grupo como a única profissional, inclusive com figurinos especialmente desenhados para a ocasião.

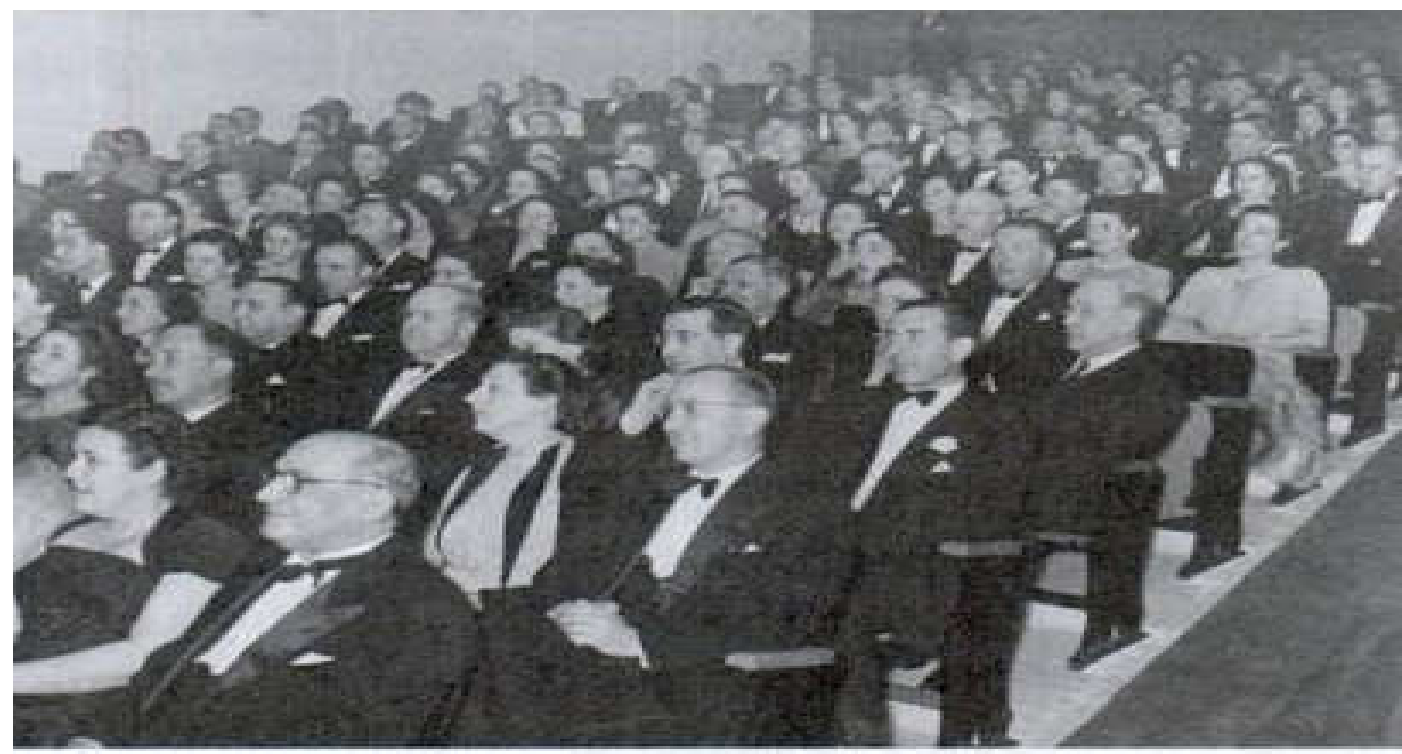

Imagem 11 - Foto da sessão de inauguração do TBC - Acervo Ruy Affonso (MATTOS, 2002)

A sessão inicial, como não poderia de ser, foi bastante concorrida e rendeu grandes receitas com o ingresso a duzentos e cinquenta cruzeiros $-66 \%$ do salário mínimo da época - ainda que não tenha sido mairo pelo grande número de convites para personalidades da classe alta, pois o evento da estreia era visto como "cortesia" à sociedade pela contribuição prévia desta para a instalação do teatro e para auxiliar na divulgação do espaço. No primeiro borderô da peça "A Mulher do Próximo", pode-se ver o número de cento e vinte e seis ingressos "devolvidos".

Essa nomenclatura designaria os que não foram vendidos em bilheteria por falta de procura, o que não foi o caso como se vê na foto da sala do teatro com seus trezentos e sessenta e um lugares totalmente ocupados em sua noite de estreia. Parecia que tanto à elite que recebeu seus convites baseado em seus nomes, bem como aos pagantes que viram no grande evento uma oportunidade de mostrar suas echarpes de Paris, o evento foi esplêndido por todos os vestidos de gala da cidade pareceram estar ao mesmo tempo nessa sessão inaugural do TBC. Uma noite de glória depois de tanto trabalho.

Nas semanas seguintes, houve a substituição de Cacilda por Nydia Lícia em algumas sessões do GTE - ela que era a atriz original para o papel em "A Mulher do Próximo". O caso desta substituição de Lícia por Becker, e sua posterior volta ao palco, 
precisa ser melhor detalhado para se ter uma idéia melhor do que passavam os artistas amadores naquele período. Nydia Lícia relata temores que sentia por pressões que havia

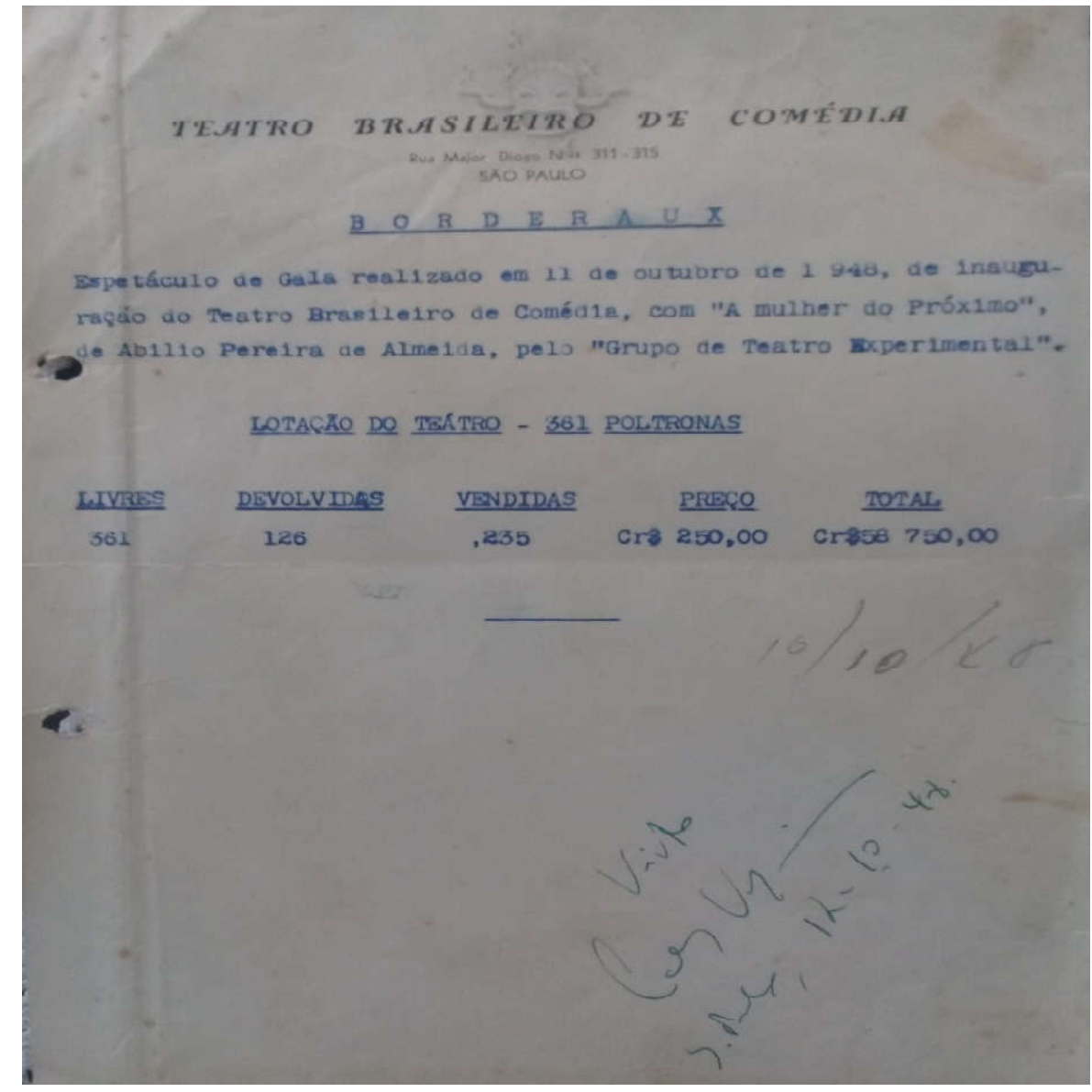

Imagem 12 - Borderô da sessão de inauguração do TBC (Acervo Gouvêa-Vaneau)

recebido no trabalho em uma botique (a Modas á Exposição Clípper) pela exposição no palco em uma peça como a de Abílio Pereira de Almeida, cuja trama tratava de casos de adultério entre freqüentadores do Jóquei Clube, bastião da elite e da classe média paulistana. Zampari ofereceu o dobro do ordenado a Lícia pela apresentação, mas a segurança do emprego em contraposição à incerteza do trabalho com o teatro a fizeram declinar da proposta no dia de estreia. Décio de Almeida Prado foi quem convidou Cacilda Becker para seu lugar, pois seu caráter profissional a faria levar o papel com segurança. Nas semanas seguintes, a situação foi contornada e Lícia voltou a atuar ${ }^{119}$.

${ }^{119}$ Cf. em LíCIA, 2007, p. 40-2 
O programa das sessões restantes no ano de 1948 trazia a estreia do GUT de Décio de Almeida Prado no espaço do TBC com "O baile dos ladrões", do francês Jean Anouilh, e sessões do English Players antes do fim do ano de 1948, seguindo uma linha inicial de alternância entre autores nacionais e estrangeiros, mas sempre com os grupos amadores. Conforme o tempo passou, essa balança vai pesar novamente mais para o lado estrangeiro que o nacional, e apesar do alívio da estreia que finalmente aconteceu, esse foi apenas o início de um processo de muito trabalho, glória e percalços pela consolidação do modelo sonhado por Zampari e amparado pela Sociedade Brasileira de Comédia em torno do TBC.

\subsection{Marcos Iniciais do TBC, Sua Profissionalização e o Contato com a} Máquina Estatal

O trabalho de consolidação da ideia do TBC, junto aos integrantes dos grupos amadores, se deu a partir do ponto de que essa nova casa pertencia a eles. A rotina e o modo de trabalho com o qual conviviam em seus tempos de amadorismo não teriam mudanças drásticas, ao menos nesse primeiro momento. Considerando que já tinham uma disciplina e uma vontade grande em mostrar serviço, trazidas por Alfredo Mesquita e pelos outros diretores, o TBC seria uma continuidade saudável da vida desses grupos e de seu entrosamento anterior. Mesmo assim, é preciso pensar que a estrutura dada pelo TBC não se comparava de nenhuma forma ao que haviam vivenciado até então, até mesmo em teatros estabelecidos como o Municipal.

$\mathrm{Na}$ reforma do espaço que abrigou o $\mathrm{TBC}$, além da seção de carpintaria e marcenaria, e da seção de costura para o vestuário - com o depósito dos cenários alugado à parte do espaço do teatro ${ }^{120}$, foi construída uma estrutura de:

Dezoito camarins, duas salas de ensaio, uma sala de leitura, uma sala de carpintaria e marcenaria, uma sala de administração, um almoxarifado de guarda-roupa, um almoxarifado de objetos de cena e um depósito de cenários usados e móveis de cena. A iluminação (construída pela metalúrgica dos Matarazzo) conta comauto-transformadores de voltagem de quarenta circuitos e o som de alta fidelidade é distribuida no palco por meio de cinco alto falantes. ${ }^{121}$

\footnotetext{
${ }^{120}$ Revista Dionysos, 1980, p.162

${ }^{121}$ Ibid., p.73
} 
Com tamanha estrutura, o teatro realmente conduzia a um desejo forte de que os amadores chamados para sua companhia se tornassem profissionais tão logo nela entrassem. Apesar do desejo, a impressão para quem acompanhava o processo de dentro dele era de que, por também terem outras atividades, os amadores não poderiam se dedicar com maior afinco à preparação de sua arte. Essa era uma das razões para que as primeiras apresentações no TBC não ultrapassassem duas semanas de temporada com grupos diferentes. Segundo Abílio Almeida, “(...) depois de quinze dias ia cada um para o seu lado, e se pensava em outra coisa. E se as peças certamente eram bem produzidas, e ricamente montadas com tudo que fosse necessário, elas não eram muito bem interpretadas." 122

Não era então a pura mudança de estrutura física que faria com que o teatro brasileiro adquirisse outro patamar, ainda mais com o ingresso nesses primeiros tempos custando quarenta cruzeiros - bem diferente do cobrado na estreia. Era preciso que se estabelecesse qual o modelo de estrutura que predominaria entre os elementos reunidos. Considerando que em paralelo aos grupos amadores exisitam outros com algum nível de profissionalização, a organização do TBC nesses primeiros tempos buscava não reproduzir totalmente o mesmo modo de trabalho de palco. A partir dessa constatação, deve-se pensar nas diferenças conceituais entre o que seria um grupo e uma companhia.

Um critério para se avaliar em termos modernos a formação de um grupo teatral como companhia seria que esta última fosse caracterizada pelo "(...) reconhecimento de seu profissionalismo e consequentemente de sua independência e capacidade para atingir o seu objetivo principal por seus próprios meios" (GUINSBURG; FARIA; DE LIMA; 2006, p. 90), para além da construção de edifícios teatrais para abrigá-la. Até aquele momento, era comum que as companhias chamadas de profissionais fossem lideradas por um ator ou atriz onde seus integrantes tinham uma divisão de papéis colocada a partir dos desígnios desse chamado primeiro ator ou atriz. Essa era a configuração das companhias europeias que visitavam o Brasil desde o Império, algo seguido então por similares nacionais.

Os grupos filodramáticos e amadores da primeira metade do século XX tiveram, desde suas primeiras manifestações organizadas no país, um caráter de ocupação social

\footnotetext{
${ }^{122}$ Entrevista à Revista Dionysos, 1980, p. 134
} 
principalmente pela sua formação predominante a partir de estudantes e trabalhadores, brasileiros ou imigrantes, que se organizavam em suas respectivas comunidades. Suas atividades teatrais eram realizadas nos clubes a fim de dar oportunidade de entretenimento e ensinamento quanto às suas realidades sociais para essas pessoas de modo a estarem "(...) desvinculados de preocupação com a bilheteria e com folha de pagamentos" (GUZIK, Op. Cit., p.10). Eles eram, portanto, agrupamentos associativos em que predominava o desapego e a junção de atividades profissionais paralelas com o didatismo com que impregnavam sua arte.

Ocorre que o tal ambiente despreocupado com sua manutenção não era de todo correto para caracterizá-los. Muito se falou sobre como os amadores penavam para manter suas atividades a partir do que recebiam, enquanto muitos deles não tinham quem os bancasse para que pudessem manter uma pesquisa mais apurada e sistemática. Nesse sentido, os grupos universitários foram uma evolução a partir das primeiras tentativas de escolas teatrais do início do século XX, pois as escolas ou grupos formados por eles tinham uma diretriz prévia dada por seus administradores.

Com o crescimento da figura do encenador, e posteriormente do diretor, como o grande intermediário entre atores e mantenedores, essa configuração começa a mudar. Enquanto o TBC tentava padronizar características básicas de sua atuação nos seus momentos próprios de definição, a partir de diretrizes dadas por Zampari e pela Sociedade Brasileira de Comédia, é possível analisar quais seriam os elementos da estrutura inicial do TBC para se constituir enquanto companhia teatral:

\begin{tabular}{|c|c|c|}
\hline \multicolumn{3}{|c|}{ ELEMENTOS ESTRUTURANTES DO TBC EM SEU INÍCIO } \\
\hline $\begin{array}{l}\text { ESTRUTURA FÍSICA E } \\
\text { ADMINISTRATIVA }\end{array}$ & $\begin{array}{c}\text { FORMAÇÃO DA } \\
\text { COMPANHIA }\end{array}$ & $\begin{array}{c}\text { MONTAGEM DO } \\
\text { REPERTÓRIO }\end{array}$ \\
\hline $\begin{array}{l}\text { - Espírito empresarial com } \\
\text { funcionamento em } \\
\text { moldes rígidos } \\
\text { - Presença constante de } \\
\text { Zampari ou de outros } \\
\text { membros da SBC } \\
\text { - Sala única adaptada para } \\
\text { cobrar preço único }\end{array}$ & $\begin{array}{l}\text { - Teatro de equipe com a } \\
\text { mescla de amadores e } \\
\text { profissionais } \\
\text { - Centralização na figura } \\
\text { do encenador como } \\
\text { responsável pela peça } \\
\text { - Busca pela estabilidade } \\
\text { do elenco }\end{array}$ & 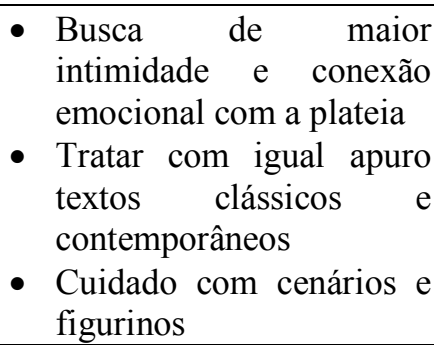 \\
\hline
\end{tabular}

A partir da análise desta estrutura, é possível ver que uma diferença que caracterizaria $\mathrm{o}$ TBC em relação às companhias consideradas profissionais até então era 
uma tentativa de uniformização em sua postura profissional. Onde antes a figura do primeiro ator/atriz como líder da companhia não buscava exigir um nível desejado de excelência do restante do elenco ou de sua produção, nas apresentações do TBC os parâmetros para se estabelecer o grupo e sua apresentação para o público mostram desde o início uma vontade de se colocar de maneira diferenciada em relação à cena teatral paulistana e brasileira. A partir daqui, a construção do "modelo TBC" passava a se desenhar de forma mais perceptível para os envolvidos no grupo e para o público em geral, que ia às apresentações no teatro com a expectativa de ver algo de alto nível.

Nessa época em que tal debate em relação á separação entre os grupos que se reuniam para promover atividades teatrais e as companhias que as fariam de maneira profissional e contínua, algo que parecia acontecer em várias partes do mundo, deu-se o nome de devising ${ }^{123}$ para designar grupos que trariam um trabalho coletivo de caráter colaborativo, mesmo mantendo certa hierarquia interna. Mas essa ideia não abarca o que seria feito a partir dali no TBC, pois tal teoria se baseava em práticas teatrais antigas que começaram a emergir naquele período em grupos considerados de vanguarda, de estética inspirada em encenadores como Antonin Artaud e Bertolt Brecht. Enquanto isso, os diretores dos grupos universitários brasileiros incorporados pelo TBC traziam uma revisitação da tradição clássica influenciada por escolas europeias, como Louis Jouvet e Jacques Copeau, franceses que foram seus grandes inspiradores.

A partir disso, é possível pensar que tais grupos não poderiam ser caracterizados da mesma forma que as companhias por seu caráter mais coletivista. Por outro lado, a forma de organização inicial do TBC, mesmo que ainda na busca por um modelo próprio, herdava vários comportamentos de seus antecessores. Interpretações diversas a respeito valorizam uma "(...) implantação do teatro de equipe formado inicialmente com base no próprio aprendizado no palco" (MAGALDI; VARGAS, 2001, p.216) por parte dos seus integrantes, ou até que “(...) muitas de suas proposições básicas (vieram dos) grandes elencos italianos imitados pelos filodramáticos, com repertório clássico, estudos paralelos aos ensaios, aperfeiçoamento progressivo dos elementos e respeito à figura do encenador" (SILVEIRA, 1976a, p.300)

${ }^{123} \mathrm{O}$ conceito de "devised theatre" (traduzido como "teatro inventado") para trabalhos em grupo é ligado a categorias de trabalho de improvisação a partir de métodos estritos. Cf. em: HEDDON, Deirdre; MILLING, Jane. Devising Performance - A Critical History, London: Macmillan-Red Globe Press, 2006 
Considerando a mudança no eixo do pensamento ocidental, que havia destronado a França como grande modelo intelectual e colocado os países anglófonos Estados Unidos e Inglaterra à frente - como os grandes referenciais a se espelhar culturalmente, havia setores que advogavam que o TBC estaria inclusive se espelhando em elementos desses países para construção de seu repertório, deixando de lado os elementos formativos dos que a constituíram. É verdade que o TBC e muitos de seus integrantes foram responsáveis por introduzir inúmeros autores desses lugares tanto em seu início como em trabalhos anteriores - a introdução de autores como Tennessee Williams e Eugene O’Neill para o público brasileiro seguramente contribuía para essa impressão. $^{124}$

Os paralelos entre o modo de trabalho dos grupos universitários e imigrantes com o que se estabelecia no TBC sugeririam assim um amálgama equilibrado entre esses métodos na composição da companhia, em que a influência dos amadores e de seus novos financiadores chegasse a um consenso conceitual. Contudo, o alegado trabalho de equipe entre atores e encenador, e as relações destes com seus mecenas, não se davam da mesma forma que nos anos 1940. A transformação nessas relações de hierarquia foi estabelecida muito pela introdução na companhia do TBC das separações das figuras do diretor geral em relação ao diretor artístico, e do encenador técnico sobre os atores.

Tais posições hierárquicas também existiam antes, porém eram mais encontradas nas companhias consideradas então como profissionais do que nas amadoras. Ainda assim, muitas vezes as funções mais importantes no trabalho de palco eram centralizadas na liderança da companbia, enquanto outros elementos acumulavam todas as outras funções possíveis - atores que também eram técnicos, por exemplo. Quando esse modelo era reproduzido por grupos amadores, isso se dava mais por instinto de sobrevivência face à falta de recursos financeiros e técnicos. Porém, o TBC estaria preparado para ir além dessas questões já em seu início.

\footnotetext{
${ }^{124}$ A revista carioca A Cigarra em janeiro de 1951 chegou a colocar o TBC como “(...) exemplo de teatro ao Brasil que segue os modelos do Theatre Guild (marco do teatro moderno de New York fundado em 1918) e do Old Vic (símbolo do teatro vitoriano de Londres desde o início do século XIX)". Com o tempo, as referências dos encenadores estrangeiros chegaram para trabalhar no TBC acabariam por suplantar essa ideia inicial do TBC como mero repetidor da estética e do modo de produção desses teatros.
} 
A pensar em sua estrutura, fazem sentido as interpretações que colocam o TBC como “(...) o primeiro grupo a se basear em pesquisas não apenas no campo cultural, mas também na área de consumo, (pois) essa mercadoria deveria ser de bom nível para atrair as classes com poder aquisitivo para ter acesso à informação" ${ }^{125}$. O modo de ação preconizado pela direção deveria fazer os integrantes da companhia crer que buscar a excelência era necessário, ainda que o elemento do entretenimento fosse colocado em cena, para que este também agregasse ao ambiente deste novo teatro da cidade. Ou seja, a maneira como o TBC foi vendido ao público fez com que uma comédia pudesse ainda ser como era, porém com um diferencial por ser apresentada naquele local.

As exigências de profissionalização cresceram com a contratação do diretor italiano Adolfo Celi, vindo do teatro amador de Buenos Aires por indicação de Aldo Calvo. Ele se torna o primeiro diretor artístico da casa com um discurso afinado à necessidade de “(...) um espetáculo mais homogêneo, isto é, artístico e honesto ao mesmo tempo" 126 através de uma continuidade de trabalho com os amadores, ao mesmo tempo que as acomodações de seus estilos de trabalho prosseguem durante todo o ano de 1949. No mesmo programa, entram uma remontagem de "Pif-Paf", maior sucesso do GTE nos anos 1940, junto a “Antes do Café”, de Eugene O'Neill, capitaneada por Madalena Nicol e o Grupo dos Artistas Amadores. A variedade das iniciativas cresce a partir de iniciativas dos atores, com a incorporação de um texto de autor cômico considerado uma revelação dramatúrgica nacional - Silveira Sampaio com seu "A Inconveniência de Ser Esposa" - e a ambiciosa e muito bem produzida montagem de "A Noite de 16 de Janeiro", de Ayr Rand, levada a cabo por Paulo Autran, do Grupo dos Artistas Amadores, e pelo diretor Ronald H. Eagling, do English Players.

Tais iniciativas poderiam pressupor que os atores estariam passando por cima da hierarquia ao não acatarem possíveis sugestões do diretor artístico, considerando que ele traria mais à cena alguns exemplares da tradição europeia com a qual se criou mas, na verdade, o que os amadores estavam fazendo era obedecer a Franco Zampari. No caso da peça de Sampaio, uma raridade dentro do repertório do TBC em seu início, ela sequer estava no repertório dos grupos que habitualmente se apresentavam no teatro. Para a montagem, Zampari convidou uma atriz carioca, Aimée, junto à sua Companhia de Comédias para se apresentarem no palco do TBC.

\footnotetext{
${ }^{125}$ DE LIMA, Mariângela Alves. Teatro Brasileiro Moderno - Uma Reflexão. In: Dyonisos, 1980, p. 24

${ }^{126}$ Entrevista ao jornal O Estado de S. Paulo de 6 de fevereiro de 1949, in: Dyonisos, 1980, p.74
} 


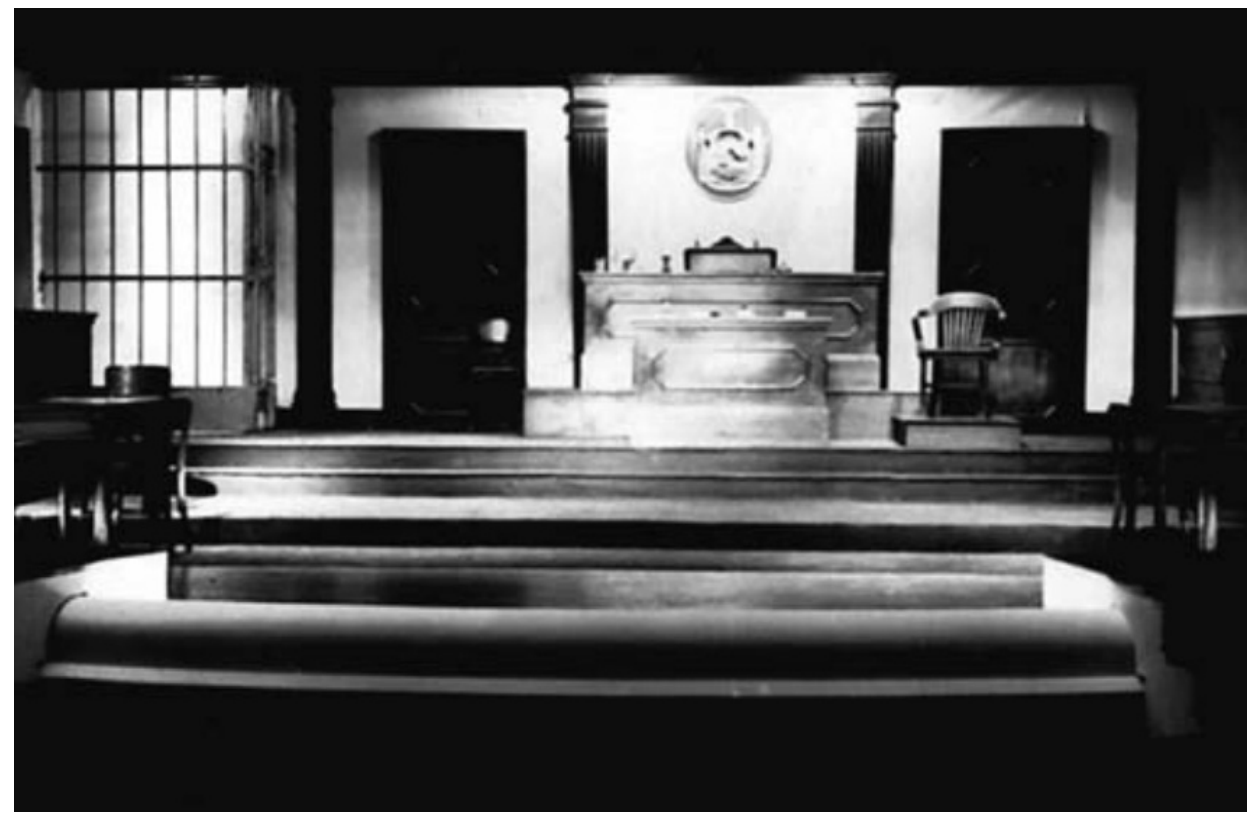

Imagem 13 - Cenário da peça “A Noite de 16 de Janeiro” no TBC (LÍCIA, 2007)

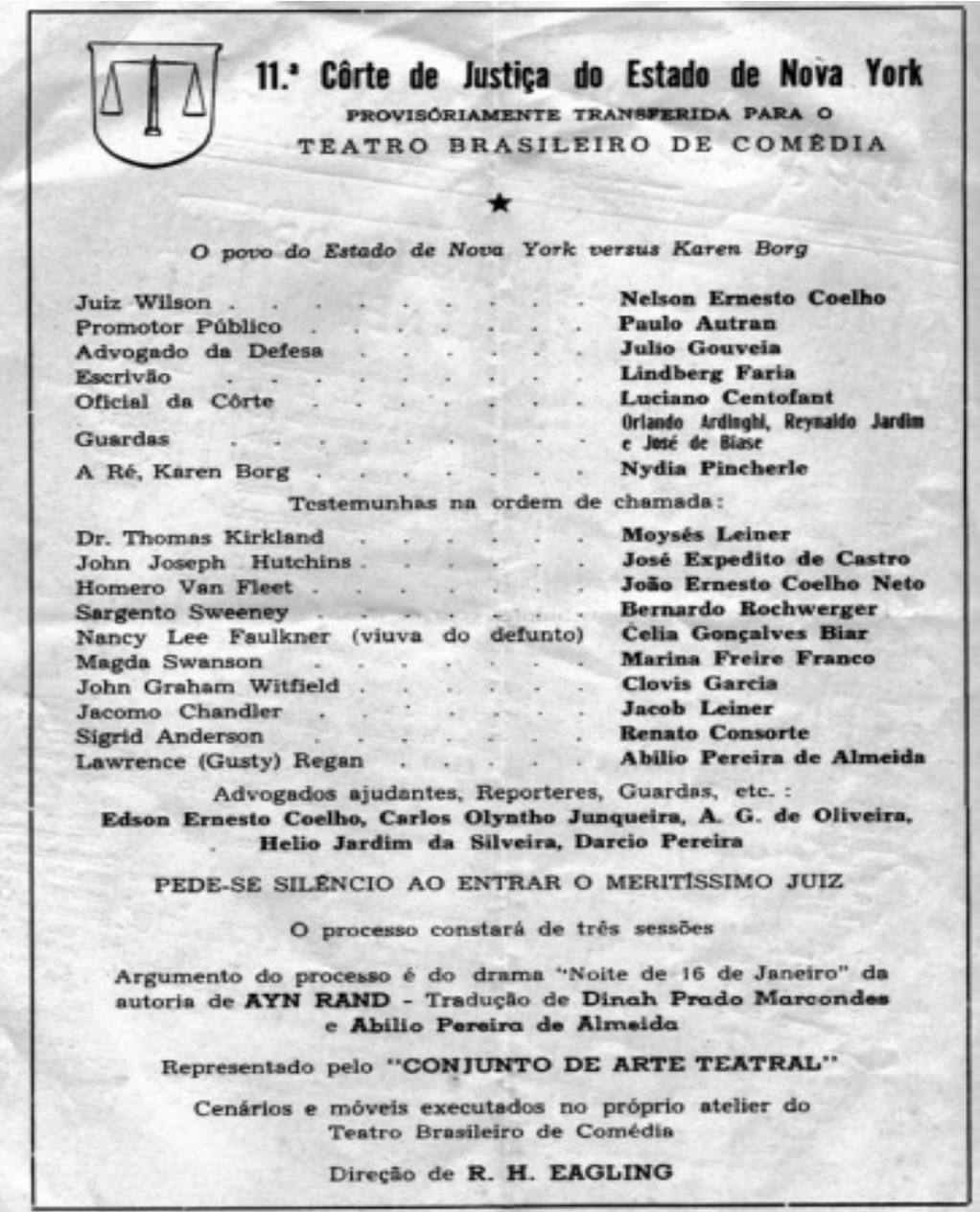

Imagem 14 - Elenco de “A Noite de 16 de Janeiro". Entre o grande elenco da peça, Paulo Autran estava na peça como protagonista, e Nydia Lícia - usando outro sobrenome - como a antagonista. Também era convocado júri entre os espectadores da peça a cada sessão. (LÍCIA, 2007) 
E no caso da peça de Ayn Rand, Zampari sugeriu montá-la no TBC após tê-la assistido nos Estados Unidos. Era muito comum que Zampari viajasse durante as temporadas do TBC pela Europa e América do Norte à caça de peças que pensava serem boas ideias para seu teatro. Nesses casos, ele se colocava como empresário de seu empreendimento, ao negociar diretamente com os produtores desses lugares a compra dos direitos de produção e exibição.

Essa diferença nas relações entre os entes superiores na hierarquia da companhia fixa do TBC ficou de certa forma mais evidente quando finalmente Zampari conseguiu chamar o diretor Ruggero Jacobbi para trabalhar no TBC em 1949, sendo o segundo diretor contratado pela empresa. Em seus primeiros trabalhos, entre dirigir um espetáculo “(...) à moda da casa e outro à minha moda"127, Jacobbi chamou para si a responsabilidade do seu trabalho perante Zampari e Alfredo Mesquita, e escolheu fazer as duas coisas. Primeiro encenando "Ele", uma comédia de costumes do francês Alfred Savoir. Depois, trabalhando em "O Mentiroso", de Goldoni, de uma tradição também revisitada há tempos em sua terra - a commedia dell'arte - para se destacar elementos como a cenografia de Aldo Calvo e a estreia de Sergio Cardoso como primeiro ator.

O sucesso dessa encenação aparou quaisquer arestas iniciais, principalmente com Alfredo Mesquita, tornando a relação entre “(...) o bom gosto - ou o gosto refinado - presentes na elaboração do espetáculo (...) e as raízes populares, algo incomum no teatro produzido até ali, (uma) referência da linha de produção subsequente da companhia” (RAULINO, 2002, p. 94-5). Mas apesar da experiência dos diretores, o que ajudou sobremaneira na construção de um pensamento profissional no TBC nesta sua fase inicial acabou por ser primeiramente a uniformização do trabalho dos elementos técnicos no teatro. Enquanto entre os diretores artísticos e os dirigentes essa sintonia ainda estava por se consolidar, os técnicos foram os primeiros a se aproveitarem da excelência dos equipamentos para mostrarem serviço de forma a marcarem presença na organização interna do espaço do teatro. Com uma estrutura que poderia ser considerada única no país naquele momento, os técnicos “(...) dispunham não somente de ambiente adequado (para trabalhar), mas também de recursos necessários e sempre à mão"128.

\footnotetext{
${ }^{127}$ Trecho de entrevista para o documentário Aventura do Teatro Paulista - o TBC gravado para a TV Cultura nos anos 1980, in: GUZIK, 1986, p. 34

${ }^{128}$ DORIA, Gustavo. Teatro Brasileiro de Comédia. In: Dyonisos, 1980, p.190
} 
Entre os atores e atrizes, também houve adaptações que perpassaram não apenas o ano de 1949, mas muitos anos além. Isso se deu principalmente na questão da acomodação a um regime de salários e contratos fixos, ou seja, de uma real profissionalização ainda não alcançada pelo teatro. Naqueles dias, apenas Cacilda Becker tinha um contrato profissional firmado com a SBC no valor de sete mil cruzeiros, correspondente ao valor de metade da lotação do teatro em bilheteria de uma sessão. Essa postura da diretoria da SBC parecia contradizer o discurso de homogeneidade, dando à ela um status de primeira atriz condizente com companhias do período prévio ao TBC.

Isso mostrava a importância que Zampari dava para a manutenção de Becker entre os componentes da companhia, apesar dela ter participado de apenas duas das dezesseis peças representadas nos dois primeiros anos do teatro. Mas como Zampari era um homem que não media esforços para fazer o "seu" teatro funcionar, com o tempo houve outros exemplos de generosidade. Nydia Lícia, que eventualmente substituía Cacilda por um acordo após a estréia do TBC, quando Lícia ficou impossibilitada de estar em cena para não contrariar seus patrões na loja em que trabalhava, não acreditava que "(...) como amadora; poderia passar pela cabeça a ideia de ganhar dinheiro fazendo teatro, (pois) dinheiro se ganhava no comércio" ${ }^{\prime 29}$.

Esse pensamento fazia sentido a Lícia, pois ela realmente sempre foi uma mulher de diversas habilidades e profissões, para quem o teatro era um complemento e não realmente o meio de maior subsistência. Porém, não era por esse motivo que ela como amadora não recebia nenhum ordenado. Zampari, por exemplo, havia the feito uma oferta para não abrir mão de sua carreira no teatro pelas pressões que sofria em seu emprego comercial. Isso era um reconhecimento por parte de Zampari do esforço construído por ela, que acompanhava os amadores desde o GTE, e que para ele não poderia perecer por razões externas. Esse pagamento também serviria como um incentivo para ela seguir adiante no projeto. Porém, apesar dos êxitos cada vez mais evidentes, mostrando que o caminho do TBC rumo à uniformidade em sua atuação estava dando resultados, o mote do teatro que tinha espírito empresarial visando a excelência artística começava a sofrer seus abalos.

${ }^{129}$ LÍCIA, 2007, p. 41. Cf. na p. 87-8 
A SBC dava mostras de que o investimento a fundo perdido prometido por Ciccillo Matarazzo a Zampari tinha seus limites. "Ingenuidade", peça do inglês radicado nos Estados Unidos John Van Durten, que foi a mais vista do TBC até então, teve uma afluência de um mil e quinhentos pagantes por semana nas cinco semanas em cartaz - o tempo de duração também foi recorde até ali. Considerando que a programação ia de terça a domingo - às quintas e sábados, havia sessão matinal devido à maior procura, ás vezes com três sessões ao sábado -, o número mostra que a sala não lotava todas as sessões. E se até então a assistência semanal era de um mil e duzentos pessoas, isso mostra que o teatro ainda não se pagava pela bilheteria.

Assim, questionava-se até quando as temporadas instituídas não deveriam trazer algum tipo de sobrevivência econômica para a entidade. A entrada definitiva de Adolfo Celi na direção para tentar mudar esse quadro se deu ainda em 1949 com "Nick Bar", nome da tradução da peça de William Saroyan que marcou o início do processo de profissionalização do teatro. Isso aconteceu primeiro pelo estabelecimento de contratos fixos de um ano, com possibilidade de renovação, em uma espécie de "estágio" da companhia TBC, o Grupo de Arte Dramática. Esse contrato foi feito em primeiro lugar comtrês participantes da montagem - além de Cacilda Becler, Madalena Nicol e Mauricio Barroso. A peça, junto da temporada feita logo em seguidade "Arsênico e Alfazema”, comédia do estadunidense de Joseph Kesselring, inaugurou uma fase de grande sucesso de público, “(...) verdadeira coqueluche em São Paulo”130 pelo TBC.

Mas essa boa fase também era acompanhada de um contratempo que buscou ser estancado, se não resolvido. Desde "Nick Bar", havia alegações de que a sala estava sempre cheia, sem que houvesse muito espaço para pagantes eventuais para esta peça que atraía o público que habitualmente ia ao TBC, o que já havia ouvido falar no teatro mas ainda não o havia frequentado, e o que foi levado pela sua repercussão. Porém, em cinquenta apresentações foram registradas oito mil pessoas, o que correspondia a quase $45 \%$ dos lugares disponíveis nas sessões. O que se depreende é que o número de convites permanecia grande ou, caso a plateia não lotasse realmente, que a disputa ferrenha de audiência na estreia e finns de semana acabaria desnivelando a ocupação nos outros dias.

${ }^{130}$ LÍCIA, 2007, p.95 
Em face dessa situação, a SBC abriria para a temporada de "Arsênico e Alfazema" uma campanha de cotistas para o teatro, que entrariam como uma espécie de sócios no empreendimento, mas apenas em relação à ocupação de lugares na sala e não na participação na Sociedade. As vantagens oferecidas eram “(...) entradas gratuitas para a estreia de peças na casa e cinquenta por cento de abatimento no preço do ingresso para os demais dias" (GUZIK, 1986, p.30). A campanha surtiu algum efeito para além do próprio sucesso da peça, ainda que com resultados insuficientes. Em noventa apresentações de "Arsênico...", o público total teria alcançado perto de vinte mil pessoas, o que na verdade preenche aproximadamente $60 \%$ da lotação máxima para esse número de sessões.

Enquanto a imprensa relata a assiduidade de um “(...) núcleo fiel e constante de espectadores, que se não tornou o teatro popular por completo, cresce dia a dia entre os que ignoravam o teatro nacional”"131, foi colocado um novo chamariz de público junto ao teatro que reviveu de maneira inconsciente um período de mudanças de hábitos teatrais, com uma nova concepção multifucional que se tornou atraente a diferentes públicos. Após o sucesso da peça "Nick Bar", um dos frequentadores habituais da casa, Joe Kantor, teve a ideia de abrir um bar que servisse refeições no almoço, e à noite fosse transformado em piano-bar, ou seja, um local intimista para se ouvir música e ter encontros sociais em um ambiente fechado e protegido. Acabou batizando-o de Joe's Nick Bar, para separar ao máximo possível o bar da peça que o inspirou e de associação societária com o teatro. ${ }^{132}$

Joe Kantor, amigo de Zampari e assíduo espectador do TBC, inconscientemente trouxe de volta a tradição chamada pelo Bar do Municipal em 1911 de servir como "buffet" e "botequim", pois além de funcionar em vários períodos do dia, servindo almoço aos técnicos e atores do teatro e demais passantes, tinha a vantagem de oferecer por cortesia jantar a quem assistia à sessão na mesma noite, já que a entrada se dava por uma porta lateral na parte interna do saguão de entrada do teatro. Assim, à noite realmente só quem houvesse pago o ingresso poderia permanecer. E com o incentivo das presenças ilustres que sempre apareciam, assim como a música de pianistas como o

\footnotetext{
${ }^{131}$ Décio de Almeida Prado em O Estado de S. Paulo de 31 de Julho de 1949, in: Dionysos, 1980, p.77

132 O Joe's Nick Bar funcionou até 1956. Cf. em NASTRI, Pedro. Nick Bar e a boemia paulista, in: São Paulo Minha Cidade, 30 de abril de 2008, Disponível em: <http://www.saopaulominhacidade.com.br/historia/ver/1622/Nick\%2BBar\%2Be\%2Ba\%2Bboemia\%2Bp aulista> Acessado em 29 de Julho de 2019
} 
italiano Enrico Simonetti, o local virou ponto de encontro referencial na cidade, forçando tambem a um aumento no preço do ingresso para as sessões noturnas, de quarenta para sessentacruzeiros, fazendo do TBC o teatro mais caro da cidade. ${ }^{133}$

Outros dois movimentos importantes para as iniciativas de Zampari foram concretizados antes do final de 1949. O primeiro deles parecia o mais ambicioso, e ao mesmo tempo o que tinha mais chance de trazer capital para si e para os de seu entorno. A partir de convites seus a dezenas de profissionais oriundos de seu círculo de encontros dominicais em sua residência, eles acabam decidindo investir em outra linguagem artística paralela ao teatro. No caso, o cinema, a partir da fundação em 3 de novembro da Companhia Cinematográfica Vera Cruz, considerada a primeira indústria do ramo em nível nacional, constituída inclusive como sociedade anônima.

Aparentemente, além do entusiasmo que novamente parece ter tomado Zampari e seus amigos a respeito do fazer artístico no país, ${ }^{134}$ esse movimento trouxe para si muitos dos mesmos investidores que se colocaram à disposição do projeto do TBC como parte da Sociedade Brasileira de Comédia, tendo Ciccillo Matarazzo como presidente da nova empresa, Franco Zampari como vice e seu irmão Carlo Zampari de diretor ${ }^{135}$, e Hernani Lopes como tesoureiro, além de outros sócios como o casal Sofia e Paulo Assumpção, Adolfo Rheingantz (estes também no TBC), Luiz Marolana, Luiz Augusto Belucci e a Rex, Kemeny \& Cia. (estes últimos como pessoa jurídica).

Da mesma forma que foram chamados profissionais italianos como Ruggero Jacobbi, Adolfo Celi e Flaminio Bollini Cerri para o trabalho no cinema, os investidores buscavam se aproveitar da intervenção sofrida ${ }^{136}$ pelos estúdios Cinecittá no período da Segunda Guerra, e após a mesma, em movimento que fez emergir no país o "Novo Realismo" com os cineastas que lá ficaram filmando em meio às ruas. Com esse colapso

\footnotetext{
${ }^{133}$ a revista Radar de junho de 1950 fala em ingresso a 55 cruzeiros na matinê, in:Dionysos, 1980, p.193

${ }^{134}$ Em entrevista, Abílio Pereira de Almeida coloca o momento da fundação da Vera Cruz como um momento de entusiasmo a partir de "(...) um filme de cinco minutos feito na casa de Zampari e revelado no domingo seguinte" que levou todos a querem ajudar a fazer cinema no país, in: GUZIK, 1986, p. 37

${ }^{135}$ Segundo a atriz Eliane Lage, essa tríade era designada por ela e outros na Vera Cruz como "Os Italianos". in: AVELAR, Alexandre de Sá; SCHMIDT, Benito Bisso (orgs.). Grafia da Vida: Reflexões e Experiências com a Escrita Biográfica. São Paulo: Editora Letra e Voz, 2013, p. 111-2 ${ }^{136}$ Cf em: AUGUSTO, Isabel Regina. VII Encontro Nacional de História da Mídia, Fortaleza, 19 a 21 de agosto de 2009. A Lição Neo Realista: a breve longa história de um movimento de resistência e libertação do cinema hegemônico. CD-Rom, 2009. Disponível em: $<$ http://www.ufrgs.br/alcar/encontros-nacionais-1/encontros-nacionais/7o-encontro-20091/A\%20Licao\%20Neo-realista.pdf> Acessado em 28 de julho de 2019
} 
da indústria local, muitos outros profissionais de excelência como Luciano Salce e também o ítalo-brasileiro Alberto Cavalcanti procuraram outras oportunidades de trabalho. Com a oportunidade aberta pela Vera Cruz, eles vieram ao Brasil, fazendo pensar nesse movimento como uma espécie de "Missão Italiana"137 cultural no país, como em uma contraposição à "Missão Francesa" que ajudou a fundar a Universidade de São Paulo.

Uma contribuição importante que se fez perceber no trabalho da "Missão Italiana" dentro do contexto teatral foi o da sistematização da formação de diretores brasileiros de teatro, cuja formação específica era quase inédita no país mesmo com as escolas de teatro existentes naquele momento. Jacobbi buscou fazer seus assistentes assimilarem um método em que se colocava como idealizador do espetáculo absoluto em contraponto ao espetáculo condicionado, como seria feito por Ziembinski ${ }^{138}$. Tal discussão conceitual contribuiu muito para o ensinamento dessas diferenças a seus atores e assistentes que futuramente fincaram pés no TBC e em projetos particulares.

Em relação à Vera Cruz, com o capital inicial de dez milhões de cruzeiros e o convite aceito por Alberto Cavalcanti para ser o primeiro diretor geral do empreendimento, o envolvimento de todos pareceu mais equilibrado do que com a SBC, onde poucos agentes parecem ter colocado mais de sua disponibilidade e capacidade de investimento no projeto TBC. O planejamento também parecia ter sido colocado de forma mais apurada desde seu início, com a compra - e não o aluguel - de um terreno para sua sede numa antiga granja em São Bernardo do Campo e de equipamento vindo dos Estados Unidos a ser instalado no local dos estúdios, e os contratos com pessoas do TBC sendo feitas em separado com a empresa de cinema. ${ }^{139}$ Essa compra dos equipamentos de cinema foi facilitada por uma iniciativa do governo federal de isentar de impostos justamente tais itens, o que se configurou como um incentivo direto ao fomento da produção cinematográfica para aqueles que podiam arcar com ela. E nesse

\footnotetext{
${ }^{137}$ Sobre o conceito de "Missão Italiana" como um movimento comum de agentes culturais italianos em direção ao Brasil, Cf. em: VANUCCI, Alessandra. A Missão Italiana: Histórias de Uma Geração de Diretores Italianos no Brasil, São Paulo: Perspectiva, 2004

${ }^{138}$ A poética teatral condicionada, segundo Jacobbi, estaria preocupada com a fidelidade ao texto e ao autor ao modo de Stanislawski e Copeau, e a absoluta com o espetáculo como domínio cênico total por parte do diretor, à moda de Artaud e Leopold Jessner, in: RAULINO, 2002, p. 42-3

${ }^{139}$ Bastos e Paniza são os nomes do BANESPA citados por Abílio Pereira de Almeida, então diretor na nova empresa, que ajudaram na separação escriturária e do caixa das duas empresas anteriormente ligadas ao mesmo dono - a Vera Cruz e o TBC. Abílio alega que tais contas se mostravam "(...) muito imiscuídas, misturadas" entre si pela atuação de Zampari, in: GUZIK, 1986, p. 66-7
} 
caso, Zampari e seus sócios da Vera Cruz não economizaram, trazendo oito toneladas de carga de New York para o Brasil, no que foi a maior carga aérea a ser transportada da América do Norte para o Sul até então ${ }^{140}$. Também se aproveitaram desse incentivo as produtoras Cinédia e Atlântida, recém fundadas no Rio.

No entanto, quaisquer possíveis impressões sobre um maior equilíbrio nas decisões de investimento por parte da diretoria da Vera Cruz a partir desse aporte inicial acabaram esvaziadas logo no início. No caso de Zampari, após ver o capital inicial ser todo dispendido sem que o projeto inicial de implementação da companhia cinematográfica fosse concluído - a Vera Cruz gastava em produção em torno de oito milhões de cruzeiros, dez vezes mais que a Cinédia no Rio -, e sem considerar a possibilidade de colocar mais dinheiro próprio no negócio, houve de sua parte pela primeira vez a iniciativa de procurar financiamentos externos para a conclusão de um projeto.

Visto que na época não existiam subsídios estatais diretos para o cinema ${ }^{141}$, ele se voltou para empréstimos em um banco estatal, o BANESPA, onde colocou tanto o patrimônio recém adquirido pela Vera Cruz como seus próprios bens como garantia de pagamento. Em primeiro lugar, esse financiamento foi usadopara a conclusão dos estúdios físicos pois a produção do primeiro filme de ficção, "Caiçara", estava sendo feita em barracões da antiga granja e em locações externas emIlhabela, litoral norte do estado, com os equipamentos sendo levados para lá de avião. Com o tempo, o trabalho cresceu da mesma forma que os juros para cobrir o empréstimo.

Porém, o ano de 1949 ainda terminou com uma boa notícia para Zampari, administrativamente falando. No dia 31 de dezembro, em meio aos ensaios normais do TBC em plena virada do ano, toda a equipe do teatro estava reunida no inteiror do prédio. Segundo relato de Nydia Lícia, não se pensava tratar essa como uma data especial, pois todos estavam comprometidos a continuarem dando sua cota de desprendimento e sacrifício natural naquele dia pela causa do teatro:

\footnotetext{
${ }^{140}$ FALCÃO, Debora Arruda; DE FRANCISCO, Flávia; RAPUANO, Raquel de Sena; GONÇALEZ, Sabrina Daniele. Vera Cruz: Novos Ideais. In: Revista PJ: BR - Jornalismo Brasileiro, ed.6, 2006, Disponível em: <www.eca.usp.br/pjbr/arquivos/dossie6_d.htm> Acessado em 31 de julho de 2019

${ }^{141}$ Essas iniciativas só foram estabelecidas por lei a partir da segunda metade da década de 1950, depois que Comissões de Cinema passaram a vigorar em prefeituras e estados, a partir de 1956 por iniciativa de Getúlio Vargas também em nível federal. Cf em: RAMOS, José Mario Ortiz. Cinema, Estado e Lutas Culturais - Anos 50, 60 e 70, São Paulo: Paz \& Terra, 1983, p.15-7
} 
Alguém pode se perguntar o que estaríamos fazendo no teatro na noite de 31 de dezembro. A resposta é simples: ensaiando! Terminamos o ano na sala de ensaio e iniciamos o ano na sala de ensaio. Este foi o nosso modo de viver no tempo em que ficamos no TBC. ${ }^{142}$

Porém, uma grande surpresa estava reservada por Zampari para todos os reunidos naquela noite. Por decisão dele em conjunto com a SBC, era chegada a hora de retribuir a todos que permaneceram na luta pelo TBC até aquele momento com a definitiva profissionalização com carteira assinada. Depois de todas as experiências com os amadores, era hora da devida efetivação da equipe da Companhia Permanente do TBC. Dela faziam parte em seu início:

\begin{tabular}{|c|c|c|c|}
\hline \multicolumn{4}{|c|}{ PRIMEIRA FORMAÇÃO FIXA DO TBC } \\
\hline \multirow{2}{*}{$\begin{array}{l}\text { Atores/Atrizes: } \\
\text { - Cacilda Becker } \\
\text { - Sergio Cardoso } \\
\text { - Célia Biar } \\
\text { - Elisabeth } \\
\text { Henreid } \\
\text { - Marina Freire } \\
\text { Franco } \\
\text { - Maurício } \\
\text { Barroso }\end{array}$} & \multirow{2}{*}{$\begin{array}{l}\text { - Carlos Vergueiro } \\
\text { - Abílio Pereira de } \\
\text { Almeida } \\
\text { - Antonio C. } \\
\text { Carvalho } \\
\text { - Ruy Affonso } \\
\text { - Nydia Lícia } \\
\text { - Waldemar Wey }\end{array}$} & \multicolumn{2}{|c|}{$\begin{array}{l}\text { Diretores Artísticos: } \\
\text { - Ruggero Jacobbi } \\
\text { - Adolfo Celi }\end{array}$} \\
\hline & & $\begin{array}{l}\text { Cenógrafos/Figurini } \\
\text { - Aldo Calvo } \\
\text { - Carlos Giacchieri } \\
\text { - Bassano Vaccarini } \\
\text { - Túlio Costa }\end{array}$ & $\begin{array}{l}\text { s: } \\
\text { - Clóvis Graciano } \\
\text { - Hilde Weber } \\
\text { Noêmia Cavalcanti } \\
\text { - Sofia Assumpção }\end{array}$ \\
\hline $\begin{array}{l}\text { Técnicos contrata } \\
\text { Maquinista - Arq } \\
\text { Supervisão de gu } \\
\text { Contra-regra - Se } \\
\text { Maquiagem e cab }\end{array}$ & $\begin{array}{l}\text { Ds: Direção de cena - } \\
\text { medes Ribeiro } \\
\text { da-roupa - Cleyde Ya } \\
\text { stião Ribeiro } \\
\text { eiras - Victor Merino }\end{array}$ & $\begin{array}{l}\text { Pedro Petersen } \\
\text { conis }\end{array}$ & \\
\hline
\end{tabular}

Apesar da boa notícia da efetivação definitiva do elenco profissional, percebe-se importantes faltas no elenco em relação aos que participaram desde o início do TBC, principalmente entre aqueles que tinham há pouco estabelecido vínculos com a SBC. Pouco antes do final do ano de 1949, Madalena Nicol, apesar de ter situação acertada com a diretoria para que seu status na companhia fosse equiparado ao de Cacilda Becker, se desentendeu enquanto ainda buscava afirmação dentro do grupo. Não por falta de capacidade, afinal já havia feito a direção de muitos espetáculos recentes, como "Ingenuidade", e até mesmo ajudou na implantação de um primeiro projeto de ocupação do teatro em seu único dia ocioso, às segundas-feiras - as Segundas Musicais, com

${ }^{142}$ LÍCIA, 2007, p. 125 
apresentações solo de intérpretes e compositores, inaugurado com apresentações da então iniciante Inezita Barroso e da própria Madalena com músicas de câmara. ${ }^{143}$

Teriam pesado na sua saída a rivalidade com Cacilda Becker, em um cenário onde a valorização da primeira atriz ainda se sobrepunha à homogeneidade do grupo e que mesmo após a equiparação contratual entre elas não teria sido totalmente resolvida, possibilitando inclusive maiores problemas com o restante do elenco. A chegada de Adolfo Celi, por exemplo, acirrou o clima de competividade entre todos e não apenas entre elas, pois Celi não abria concessões entre quem estava dentro ou fora da companhia para estabelecer quem se encaixava melhor em suas intenções cênicas - na primeira peça dirigida por ele, "Nick Bar", Celi chegou a fazer testes com atores de rádio e até mesmo com jovens que nunca haviam representado. ${ }^{144}$

O primeiro a ter seu trabalho destacado nesse processo de valorização atoral de Celi foi Sergio Cardoso, que tendo vindo do Teatro dos Doze ${ }^{145}$ chegou ao TBC para brilhar definitivamente a partir da montagem de "O Mentiroso". Outro exemplo de crescimento e lenta consolidação de trabalho, que acabou marcando época em sua geração, se deu com o ator Paulo Autran. Ele que esteve em torno do TBC desde seu início, foi construindo sua trajetória até o momento em que se colocou por inteiro na montagem de “A Noite de 16 de Janeiro", de Ayn Rand, em 1949, atuando e produzindo a peça com trinta pessoas, entre atores e elementos extras como pessoas do público chamadas para o júri da peça eatores pagos para serem jornaleiros na porta do teatro no intervalo para venderem jornais - na verdade, os programas da peça.

O esforço coletivo capitaneado por Autran, mesmo considerando as dificuldades para se estabelecer posições fixas nesse início do TBC - diretores atuavam, atores faziam cenografia e ajudavam no vestuário, a depender da peça em que atuavam ${ }^{146}$ teve tal êxito que a encenação ficou marcada como o início do fim da era dos amadores

\footnotetext{
${ }^{143}$ LíCIA, 2007, p. 93

${ }^{144}$ Ibid., p. 83

${ }^{145}$ Grupo amador fundado no Rio de Janeiro por Paschoal Carlos Magno após o Teatro do Estudante. Fizeram também parte dele o ator Sergio Britto e o diretor Ruggero Jacobbi antes de chegarem ao TBC ${ }^{146}$ Maria Thereza Vargas descreveu o início de carreira de Sergio Cardoso no TBC ilustrando como muitos que chegavam acumulavam funções: "Ampliando sua condição de ator, prontificou-se a ser assistente de Luciano Salce em "O Anjo de Pedra", reservando a si uma breve e patética aparição como Archie Kramer em "O caixeiro viajante", no final da peça. Também desenhou figurinos e cenários para "O Inventor do Cavalo", e passou noites assistindo às iluminações de Ziembinski." (LíCIA, 2008, p.17).
} 
no TBC, deixando assim de se tornar um conglomerado de artistas capitaneados por um mecenas em torno de escolas de teatro para se tornar um corpo orgânico e entusiasmado que começava a se colocar como donos das próprias ações perante a arte que escolheram.

Autran, no entanto, também não teve contrato efetivado com o TBC nesse momento, preferindo continuar envolvido com seu escritório particular de advocacia, da mesma forma como enquanto se dedicou à montagem de "A Noite de 16 de Janeiro". Ele, porém, não deixou de ser contratado por demonstrar falta de comprometimento com o TBC ou o teatro em geral. É possível que tenha pensado no fato de se doar tanto enquanto amador, sem ter visto a perspectiva de que o TBC se tornasse profissional no curto prazo. Para animá-lo a continuar no teatro, a atriz Tônia Carrero então o convidou para participar em dezembro de 1949 da montagem de "Um Deus dormiu lá em casa", de Guilherme Figueiredo, no teatro Copacabana no Rio de Janeiro. Esse acabou sendo o passo decisivo para sua profissionalização, ainda que tivesse se dedicado ao TBC desde quase seu início.

Madalena Nicol, sua companheira do Grupo de Artistas Amadores, teria seguido o mesmo caminho na sua afirmação como atriz, também por estar envolvida com diversos projetos antes e depois do TBC. Ela havia colaborado em 1948 com a montagem de "A Esquina Perigosa" pelo Grupo de Teatro Amador de Pernambuco, dirigido e cenografado por Ziembinski após a dissolução do grupo Os Comediantes no Rio. Tanto ela como outros no TBC daquele período levaram montagens feitas naquele teatro para outras cidades com produção própria, desvinculada do teatro da Bela Vista. Isso também ocorreu com Abílio Pereira de Almeida quando Jorge Guinle, proprietário do Copacabana Palace, convidou-o no mesmo ano de 1949 para reinaugurar recémreformado Teatro Copacabana com suas peças "A Mulher do Próximo" e "Pif-Paf"147.

O ano de 1950, primeiro então da plena constituição da companhia TBC, começou com aquela que foi sua peça mais contemporânea encenada até então: "Entre Quatro Paredes", do francês Jean-Paul Sartre, então ícone maior da filosofia existencialista que ensejava discussões acaloradas sobre a posição do ser humano perante o mundo e suas implicações de poder, além de um forte questionamento de

${ }^{147}$ LíCIA, 2007, p.62 
instituições da religião e da política. A peça trazia um extremo jogo psicológico num tour de force entre os três atores principais da peça: Nídia Lícia, Sergio Cardoso e Cacilda Becker. Certamente, entrar na seara das questões contemporâneas, deixando um pouco de lado visões clássicas ou meras críticas de costumes como vinha fazendo até então, trouxe pela primeira vez para o TBC algum questionamento tanto de setores da sociedade civil como do próprio aparato estatal.

Isso fez com que os primeiros ensaios não tivessem a presença de nenhuma outra pessoa além das responsáveis pela montagem, o diretor Adolfo Celi e os atores principais escolhidos (Carlos Vergueiro, outro ator escalado para a peça, só fazia um papel curto de introdução das protagonistas e acabou de fora dos ensaios particulares). Nem mesmo os outros integrantes da companhia, que ensaiavam paralelamente "Um Pedido de Casamento", de Antón Tchékov - a ser apresentado em conjunto com a peça de Sartre por decisão da SBC - podiam acompanhar o que se passava com Celi e os atores da peça de Sartre no ensaio.

Apesar de relatos que diziam que os ensaios fechados eram um procedimento normal para o grupo nesse início, havia uma preocupação com a integridade dos artistas envolvidos, pois o existencialismo professado por Sartre já havia sofrido retaliação oficial das instituições, com nota publicada pelo arcebispo da cidade conclamando aos católicos a não assistirem à peça, e chamada do Partido Comunista (na época, fora das instâncias parlamentares) para seus integrantes e simpatizantes fazerem o mesmo. Houve também um episódio onde a polícia foi ao prédio do TBC verificar o que teria se passado num "baile de Carnaval existencialista" promovido pelos atores da companhia, em conjunto com membros do Clube dos Artistas e Amigos da Arte ${ }^{148}$, no Golf Club Anastácio de Pirituba. A notificação da polícia virou motivo de riso por estar endereçada ao próprio Sartre, tendo sido recebida por Célia Biar, que prometeu que a carta seria entregue em mãos. ${ }^{149}$

\footnotetext{
${ }^{148}$ O clube dos Artistas e Amigos da Arte (CAAA), ou Clubinho, foi criado em 1945 do encontro de artistas de várias expressões e linguagens que freqüentavam o bar próximo à primeira sede do MASP, na rua Sete de Abril, se transferindo com o apoio de Ciccillo Matarazzo para a sede do IAB (Instituto dos Arquitetos do Brasil) na Rua Rego Freitas até os anos 1960. Hoje no local funciona a Central Galeria. Cf. em: CENTRAL GALERIA, Clubinho dos Artistas, Disponível em: $<$ https://www.centralgaleria.com/clubinho> Acessado em 31 de Julho de 2019 ${ }^{149}$ LÍCIA, 2007, p.67-8
} 


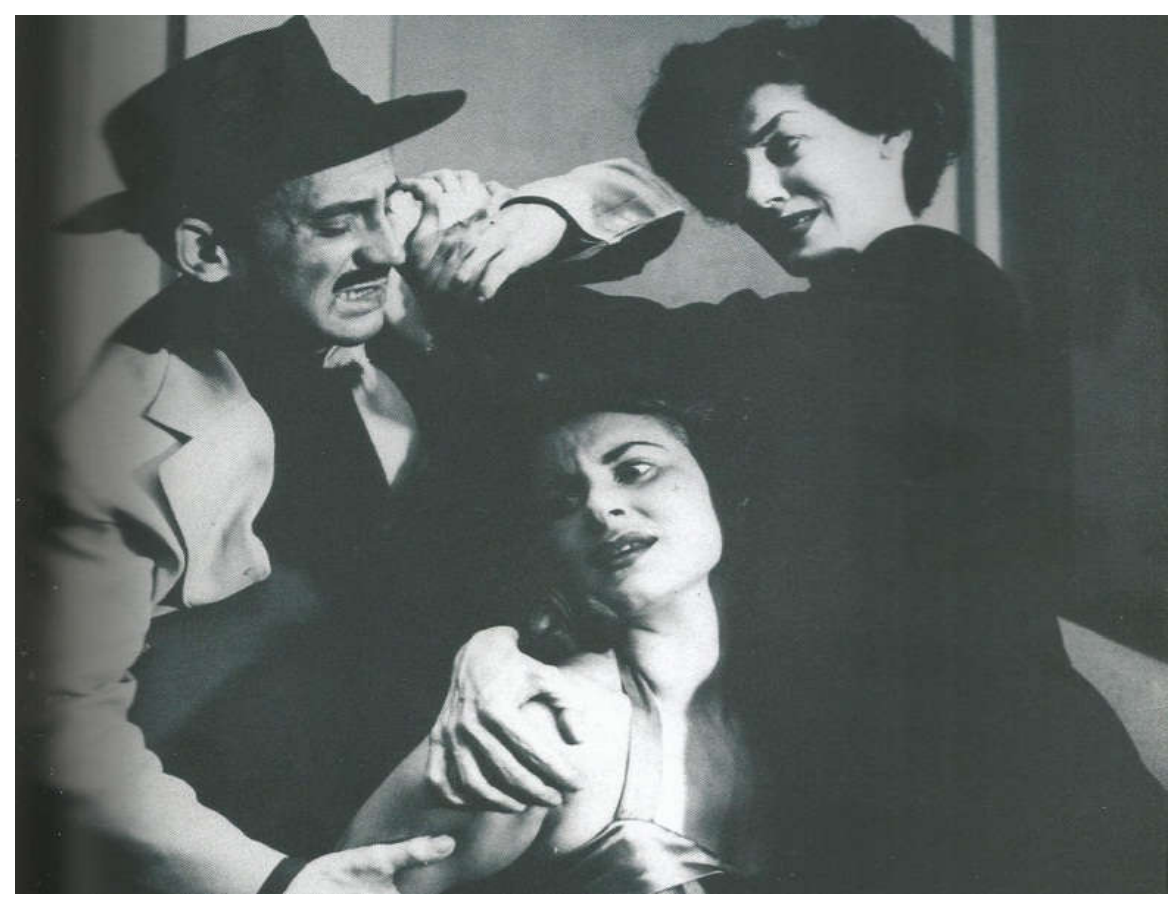

Imagem 15 - Sergio Cardoso, Nydia Lícia e Cacilda Becker em “Entre Quatro Paredes” (GÓES, 2007)

Apesar do episódio jocoso da notificação a Sartre, isso mostrava que o teatro estava sob os olhos das autoridades e da sociedade. A tal festa saiu no dia seguinte em jornais como o Diário da Noite - um dos pertencentes a Assis Chateubriand - com fotos de distintas pessoas do teatro bêbadas e largadas no chão, sob título de "Pagodeira Existencialista", numa tentativa de ridicularizar os "discípulos de Sartre" presentes à festa. E a recepção de Biar dizendo que entregaria "pessoalmente" a intimação não adiantou por muito tempo para manter o TBC fora dos olhares do Gabinete de Investigações do órgão estadual da censura prévia a espetáculos, em operação desde 1928. Foi então marcado um ensaio com três inspetores em janeiro de 1950 logo após o ensaio geral, o último antes da estreia, em busca de elementos para censurar a peça.

À meia noite, estavam presentes os censores junto à diretoria da Sociedade Brasileira de Comédia e outras testemunhas. O clima de nervosismo no ensaio tentou ser amenizado por declaração de Cacilda Becker e Sergio Cardoso antes de seu início dizendo que, como católicos praticantes, haviam se declarado naquele dia aos seus padres confessores, e deles obtido autorização para representar a peça. Após o término do ensaio geral, o aplauso puxado pelos próprios censores mostrava aos envolvidos que a peça estava enfim liberada, apesar da restrição de assistência apenas para maiores de 18 anos. 
Mattos Pacheco, então presente ao ensaio como repórter dos Diários Associados, ajudou a repercutir essa tentativa de censura prévia publicando as declarações dos censores que acompanharam o ensaio geral nos jornais do grupo no dia seguinte. Foram destacadas na reportagem, como forma de mostrar o posicionamento das autoridades, as falas do Sr. João Carneiro da Fonte, da Secretaria de Segurança Pública, que expressa que “(...) não se permitiria uma peça imoral (no que) felizmente, "Entre Quatro Paredes" não pode ser tachada como tal (ressaltando) orgulho do trabalho que vai apresentar o TBC" "150, e do Sr. Blumer Couto, Chefe do Serviço de Diversões Públicas, declarando-se “(...) constrangido se tivesse de vetar a peça (mas) felizmente o Serviço de Censura apenas proibiria a presença de menores de 18 anos, pois não estariam à altura de compreender o drama."151

A peça consegue, a partir de todo esse impasse, se tornar um enorme sucesso, com dezesseis mil pagantes para suas sessenta e sete apresentações, fazendo Franco Zampari mais uma vez se encher de euforia para vaticinar: "Eu não disse? Eu não disse que teríamos um teatro tão bom quanto o europeu e o americano?" ${ }^{152}$. Décio de Almeida Prado, no entanto, se mostrava menos otimista que Zampari quanto à efetividade artística da encenação de Sartre, por ter visto nela “(...) uma visão do inferno menos original que a pretendida pelo autor" ${ }^{\prime 153}$.

Apesar de contrariar a opinião do dono do empreendimento, Décio de Almeida Prado seguiu naquele momento, e ainda por muito tempo, sendo o grande escudeiro do projeto do TBC na imprensa, considerando os envolvidos em sua concretização - atores, atrizes, cenógrafos, técnicos e administradores - como um “(...) esquadrão cerrado e aguerrido que em poucos anos subverteu todo o quadro do teatro brasileiro, imprimindo-lhe novas práticas e princípios" ${ }^{\text {"154 }}$. Com tudo isso, o teatro da Rua Major Diogo começou a experimentar os sinais do que viria á frente, quando o fato de ser um empreendimento privado não o isentou de buscar a salvaguarda do Estado quando necessário.

\footnotetext{
${ }^{150}$ LÍCIA, 2007, p. 133-4

${ }^{151}$ Idem Ibidem

152 LÍCIA, 2007, p. 133-4

153 GUZIK, Op. Cit., p. 38

${ }^{154}$ apud PONTES, 2011, p. 185
} 


\subsection{Consolidação do "modelo TBC" e as Políticas Públicas}

O esforço de aglutinação de forças protagonizado por Zampari em torno do TBC é uma marca indefectível de um processo que se consolidou naquele contexto onde o mecenato cultural impresso e incentivado pela migração europeia para São Paulo, junto à emergente intelectualidade local vinda da universidade, “(...) imprimia um ar cosmopolita (à cidade) alterando a estratificação social, expandindo e diversificando a ocupação do espaço, resultando em formas renovadas de sociabilidade."155 Esse movimento perdurou em muitas outras iniciativas na cidade desde o fim dos anos 1940 até pelo menos 1954, quando São Paulo celebrou o IV Centenário de sua fundação.

A entrada do ano de 1950 em especial foi o auge desse movimento que estava mudando a face cultural da cidade de São Paulo. No decorrer da primeira metade da década, e particularmente nesse ano, muitos projetos pensados pelo mecenato privado começaram a se concretizar da mesma forma que o TBC se consolidava como companhia permanente, com prédios culturais sendo inaugurados para o público construindo um legado permanente. Em 1950, houve a abertura do Teatro Cultura Artística, cujas obras foram iniciadas em 1946; o MAM abre seu Clube de Cinema que se transformaria no embrião da Cinemateca Brasileira; e o MASP teve o crescimento e consolidação do projeto curatorial de Yolanda Penteado e Assis Chateaubriand com o Instituto de Arte Contemporânea de Lina Bo Bardi, oferecendo um espaço que ia além de um museu, na preparação da saída do prédio comercial da Rua Sete de Abril para o nobre e majestoso edifício próprio na Avenida Paulista projetado por ela, que depois da inauguração em 1950 se tornaria cartão postal da cidade.

Nos empreendimentos de Zampari, tudo parecia caminhar para um eixo de grandes realizações e prosperidade ao empreendimento. Ao mesmo tempo, a alta concentração de investidores em seus projetos, "(...) exprimindo a concentração das iniciativas culturais no período no grupo fechado dos mecenas" (ARRUDA, 2005, p.146), poderia significar maior risco caso Vera Cruz e TBC fossem mal sucedidos. Mas o fato de que tanto estes como outros empreendimentos culturais, no caso o MASP e o MAM, atingiam seus objetivos na promoção de uma cidade cada vez mais cosmopolita e culturalmente pulsante, dava a todos os envolvidos uma sensação de auto-suficiência e

${ }^{155}$ ARRUDA, 2001, p.20 
até mesmo onipotência, onde com a ajuda dos estrangeiros “(...) todos queriam participar em todos os lugares, até mesmo nas questões técnicas"156. A partir dessa maneira de trabalhar, a sinergia entre Vera Cruz e TBC era vista por Zampari não apenas como olhar de investidor em seus negócios, mas como participante ativo. Guzik faz uma reflexão sobre como esse ponto justo entre aspirações de Zampari e suas realizações teriam sido atingidos nesse momento de sua ação:

Com a Vera Cruz exibindo suas primeiras produções e o TBC realizando outras dezesseis montagens no ano, com bom afluxo de público e estímulos por parte da imprensa especializada, em 1950 Zampari deve sentir-se vitorioso. [...] o alardeado desempenho cultural da companhia busca uma acomodação dificil com as necessidades da bilheteria, mas a favor de Zampari deve-se ponderar que ele não cogita abandonar a ambição cultural e aspira a encontrar um ponto de equilíbrio. $O$ quadro técnico da casa foi ampliado, assim como o elenco. Os espetáculos apresentados passam a ter a reputação de ótimo acabamento $^{157}$

Esses esquemas de produção caracterizados pela atuação do TBC e dos outros empreendimentos culturais mencionados parecem ter sido possíveis naquele momento histórico apenas, pela ação destemida e de certo modo coordenada entre investidores que buscavam construir um legado para o país, e que se vangloriavam de não receber apoio governamental. Diferentemente de pensar em como essa estrutura seria diferente se tivesse havido maior intervenção do Estado, é mais que necessário se perguntar como isso se manteve funcionando por anos a fio, e quais foram os meios garantidores para essa estrutura seguir influenciando outros empreendimentos de diferentes matizes.

No caso do TBC, após a diretoria da SBC partir de uma sensação de definição das diretrizes do seu trabalho com a formação de sua primeira equipe fixa, ela fez-se então introduzir um sistema interno de regras inspirado nas que Alfredo Mesquita havia estabelecido para a EAD nos anos 1940, e que assim como estas, perduraram por vários períodos e diferentes gestões na direção geral. Essas regras eram separadas entre gerais e as específicas para cada função técnica exercida dentro do TBC - desde os artistas e diretores, até os maquiadores, guarda-roupeiros, maquinistas e eletricistas - tratando de direitos e deveres de todos os contratados da companhia.

\footnotetext{
${ }^{156}$ ARRUDA, 2001, p.125-6
}

${ }^{157}$ GUZIK, Op. Cit., p. 49 
As regras gerais tratavam de questões de disciplina de trabalho, porém também eram resguardadas muitas questões de patrimônio do $\mathrm{TBC}$, com proibições e recomendações a serem seguidas no cotidiano interno de trabalho. Abaixo, é possível comparar pontos em comum que se articulavam entre as regras Gerais do TBC e a legistação vigente seguida pela direção do teatro:

\begin{tabular}{|c|c|}
\hline & \\
\hline $\begin{array}{l}\text { Artigo } 1^{\circ} \text { - Conservar sempre elevada linha } \\
\text { de conduta e disciplina } \\
\text { Artigo } 2^{\circ} \text { - qualquer despesa realizada por } \\
\text { diretor, cenógrafo, componente do elenco, } \\
\text { técnico ou funcionário só será permitida } \\
\text { mediante autorização da diretoria } \\
\text { Artigo } 3^{\circ} \text { - Manter o mais rigoroso silêncio } \\
\text { durante espetáculos nos corredores e } \\
\text { bastidores } \\
\text { Artigo } 4^{\circ} \text { - a diretoria desse teatro não se } \\
\text { responsabiliza pelo roubo de objetos pessoais } \\
\text { deixados nos camarins } \\
\text { Artigo } 5^{\circ} \text { - em caso de dano ocasionado por } \\
\text { qualquer empregado, incluindo todo o } \\
\text { pessoal artístico e administrativo, fica } \\
\text { facultado ao TBC descontar no respectivo } \\
\text { ordenado e correspondente prejuízo } \\
\text { Artigo } 6^{\circ} \text { - é expressamente proibida a entrada } \\
\text { na bilheteria do teatro de pessoal estranho } \\
\text { àquele serviço } \\
\text { Artigo } 7^{\circ} \text { - as infrações contratuais aqui } \\
\text { expressas estarão sujeitas às penalidades de } \\
\text { advertência, suspensão de até } 30 \text { dias e } \\
\text { rescisão do contrato de trabalho, nos casos } \\
\text { previstos no artigo } 482 \text { da CLT } \\
\text { Artigo } 8^{\circ} \text { - o presente regulamento interno } \\
\text { faz parte integrante dos contratos individuais } \\
\text { de trabalho e todo o pessoal que com o teatro } \\
\text { mantém relações de emprego, para todos os } \\
\text { fins e efeitos de direito }\end{array}$ & $\begin{array}{l}\text { Constituem justa causa para rescisão do } \\
\text { contrato de trabalho pelo empregador: } \\
\text { a) ato de improbidade; } \\
\text { b) incontinência de conduta ou mau } \\
\text { procedimento; } \\
\text { c) negociação habitual por conta própria ou } \\
\text { alheia sem permissão do empregador, e } \\
\text { quando constituir ato de concorrência à } \\
\text { empresa para a qual trabalha o empregado, } \\
\text { ou for prejudicial ao serviço; } \\
\text { d) condenação criminal do empregado, } \\
\text { passada em julgado, caso não tenha havido } \\
\text { suspensão da execução da pena; } \\
\text { e) desídia no desempenho das respectivas } \\
\text { funções; } \\
\text { f) embriaguez habitual ou em serviço; } \\
\text { g) violação de segredo da empresa; } \\
\text { h) ato de indisciplina ou de insubordinação; } \\
\text { i) abandono de emprego; } \\
\text { j) ato lesivo da honra ou da boa fama } \\
\text { praticado no serviço contra qualquer pessoa, } \\
\text { ou ofensas físicas, nas mesmas condições, } \\
\text { salvo em caso de legítima defesa, própria ou } \\
\text { de outrem; } \\
\text { k) ato lesivo da honra ou da boa fama ou } \\
\text { ofensas físicas praticadas contra o } \\
\text { empregador e superiores hierárquicos, salvo } \\
\text { em caso de legítima defesa, própria ou de } \\
\text { outrem; } \\
\text { 1) prática constante de jogos de azar. }\end{array}$ \\
\hline
\end{tabular}

Fonte: Acervo Gouvêa-Vaneau; site do Planalto

Importante destacar que o penúltimo artigo das regras gerais endossava o fato de o cumprimento de tais regras estar atrelado ao contrato de trabalho estabelecido com a SBC, seguindo especificamente o artigo 482 da Consolidação das Leis de Trabalho (CLT), promulgada em 1943 e que elenca em sua forma original doze situações 
passíveis de demissão por justa causa, todas elas conformes com as regras gerais estabelecidas pela SBC. Curioso pensar também que o trabalho teatral dentro do profissionalismo tenha mudado dessa forma das companhias mais centralizadas da primeira metade do século XX para os desta fase que se pretendia mais homogeneizada em suas relações. Após o Estado Novo, em 1946, entrevistas com empresários feitas pelo SNT colocavam o artista e o trabalhador do teatro como entes separados.

Porém, enquanto o trabalhador tinha garantidos vínculos de trabalho, podendo até mesmo adquirir estabilidade dependendo da longevidade da companhia e de seu tempo de serviço ${ }^{158}$, o contrato de trabalho do artista era feito por apresentações, por peças a serem elaboradas ou por um espaço determinado de tempo. ${ }^{159}$ Isso se devia ao fato de que a CLT não havia antes sido usada para garantir direitos dos artistas e demais profissionais especializados em relação ao pagamento de ordenados de maneira regular. Para eles, vigorava o estabelecido no Decreto 5492 (a chamada "Lei Getúlio Vargas") de 1928 , que colocava no artigo $5^{\circ}$ o trabalho de artista como "locação de serviço" por tempo determinado.

Assim, por terem contratos feitos de forma isolada, os artistas ganharam a fama de serem mais descompromissados e afeitos à boemia, impressão que ainda não era totalmente apagada do imaginário popular no início dos anos 1950. O TBC apenas estabeleceu então um novo parâmetro salarial equiparando o status trabalhista de artistas e técnicos, dando tambem aos artistas maiores salários e garantias que antes. Nesse contexto, é possível que Madalena Nicol ao já ter assinado compromisso com o TBC mas, tendo desistido de seguir adiante pouco depois, não tivesse se sentido à vontade em estar amarrada a esse tipo de regulação nos momentos de definição da equipe. Essa questão era premente para muitos entre os que ali estavam e que não tiveram contratos fechados nesse momento.

Esses que ficaram nessa situação eram os "colaboradores", artistas ou técnicos que eram novatos ou com vínculo empregatício precário, chamados para trabalhos pontuais ou períodos específicos. Essa configuração também prosseguiu durante a fase profissional do teatro. Esse ambiente dos trabalhadores mais precarizados, assim como

\footnotetext{
${ }^{158}$ Deve-se levar em consideração que haviam leis trabalhistas antes da promulgação da CLT, regidas pela Organização Internacional do Trabalho (OIT), órgão fundado em 1919 do qual o Brasil é membro ${ }^{159}$ VERAS, 2011, p.4.
} 
dos técnicos contratados, era um verdadeiro universo paralelo dentro do TBC que sempre parecia estar em construção durante as várias fases de elaboração de uma montagem. O trabalho fabril dos figurinistas, costureiras, maquiadores, maquinistas, eletricistas e cenotécnicos como contrarregras começava “(...) quando o sol aparecia, as portas do guarda-roupa eram abertas, a marcenaria iniciava sua tarefa brilhante, e seguindo orientação do cenógrafo e figurinistas, dava-se inícioà montagem de parte daquilo que público apreciaria como elemento integrante da peça encenada"160.

Entre as regras específicas, prevaleciam as questões técnicas, com destaque para a separação no provimento de vestuário dado pelo teatro. No caso das atrizes, elas teriam que trazer consigo apenas quaisquer acessórios ou adereços que achassem importantes para compor sua personagem, pois o vestuário delas era inteiramente fornecido pela SBC e cuidado pelos figurinistas e pelo diretor da montagem. No caso dos homens, o vestuário era fornecido pelo teatro apenas para o caso de montagens de época - se a vestimenta exigida pela personagem fosse "moderna", o ator deveria trazer sua própria roupa, o que fazia sentido para quem elaborou a regra, pois essa era naquela época a vestimenta comum masculina no cotidiano.

Cleyde Yáconis foi uma das pessoas que passou por esse trabalho no guardaroupa permanecendo no teatro e buscando a partir dele outras oportundiades. Não apenas por ser irmã de Cacilda Becker, ela era um das que sempre colaborava com o trabalho frenético no ambiente do TBC, na função de guardar os trajes confeccionados no início da companhia, que somariam dois mil em toda a sua trajetória. Não que isso fosse novidade em sua vida: ela e Cacilda Becker podem ser consideradas as pessoas de origem mais humilde dentre os contratados para as funções artísticas. Cacilda disse em outras oportunidades ter trabalhado em seu próprio figurino na fase pré-TBC, da mesma forma que ambas também costuravam seus uniformes escolares para irem ao colégio.

Nesse contexto, a EAD seguia funcionando da mesma forma no segundo andar do prédio do teatro, com seus alunos assistindo às suas peças de modo imperativo, ainda que sem haver remuneração para seus professores. Sendo Alfredo Mesquita o responsável maior pela gestão da escola e pelo provimento de suas necessidades, ele continuava buscando fontes de recursos para sua continuidade. Até mesmo Zampari e a

\footnotetext{
${ }^{160}$ SERRONI, José Carlos. O Outro Lado da Ribalta, in: SECRETARIA DE ESTADO DA CULTURA, Cenografia e Indumentária no TBC: 16 anos de História (1948-1964). São Paulo, 1980, p.36
} 
irmã de Alfredo, entre outros, ajudavam com doações generosas para sua manutenção. ${ }^{161}$ Somente no fim de 1951, ele obteve êxito em fechar um convênio com a Prefeitura de São Paulo para a partir do ano seguinte receber um auxílio do Convênio Cultural de Ensino, após relatório interno apontar que a escola “(...) só se mantinha pelas doações particulares", e assim finalmente foi possível pagar os mestres especialistas da casa. ${ }^{162}$

Isso ajudou na manutenção e ampliação de matérias de professores especializados na escola, para além das matérias usualmente oferecidas - dicção, mímica, comédia, cenografia e drama. Entre as matérias novas, destaca-se História do Teatro, ministrada por Décio de Almeida Prado e pouco depois por Sabato Magaldi, além das aulas de língua portuguesa e suas diversas expressões, com professores como Leila Coury, a mais longeva professora da casa, e o poeta Guilherme de Almeida. Tal valorização da língua não era subestimação à formação prévia dos alunos, mas uma decisão da escola em consonância com a resolução do $1^{\circ}$ Congresso Brasileiro de Teatro, realizado no Rio de Janeiro em 1951 - ano do início do novo mandato eletivo de Getúlio Vargas -, que instituiu curiosa proposta do dramaturgo Henrique Pongetti, que colocava “(...) após exaustivos debates, o modo de falar carioca como prosódia-padrão do teatro nacional"163.

Assim, era preciso adaptar-se por tal resolução estar consonante com a intenção do governo de a partir dali incentivar a formação de uma nova companhia estatal com um teatro-escola federal. O mesmo Congresso reeditou uma política do SNT feita na década de 1940 e criou um novo Conselho Consultivo de Teatro, desta vez sem se ater à indicação de personalidades do meio artístico e se concentrando desde o início em congregar representantes de entidades e organizações de classe como a SBAT; sindicatos de atores, técnicos e empresários; e associações de críticos de várias partes do país. ${ }^{164}$ Esse Conselho vigoraria até 1964 com a fnalidade de deliberar sobre propostas de subvenções junto ao SNT, sendo essa sua principal atividade desde sua constituição.

\footnotetext{
161 GÓES, 2007, p.250

${ }^{162}$ SILVA, 1989, p.52

${ }_{163}$ MICHALKSI; TROTTA, 1992, p.73

${ }^{164}$ Estavam presentes no primeiro Conselho Consultivo de Teatro as entidades: SBAT, Sindicatos dos Atores Teatrais, Cenógrafos e Cenotécnicos do Rio de Janeiro e de São Paulo (ligados à Casa dos Artistas, seus desdobramentos regionais se tornariam o que é o SATED hoje), a Associação Brasileira de Críticos Teatrais ( $A B C T)$, aAssociação Brasileira de Proprietários de Circo e Empresários de Diversões,a
} 
Como política pública no âmbito municipal, além do apoio para apresentações pontuais no Municipal ou em outros espaços da prefeitura, seguiam sendo concedidos apoios financiados sobretudo pela Secretaria de Educação para projetos que congregassem cultura à formação. Nesse sentido, houve a iniciativa de Tatiana Belinky e Julio Gouveia, pioneiros do teatro voltado para o público infanto-juvenil, no Teatro Escola de São Paulo (TESP), que trabalhava junto à Prefeitura em turnê constante por espaços públicos entre 1949 e 1951, se estabelecendo em 1952 como Teatro da Juventude em sede própria, com importante participação de Antunes Filho na sua implantação. Esse parecia o máximo de incentivo do município à formação teatral além da ajuda pontual à $\mathrm{EAD}$, visto que Aldo Calvo chegava a se queixar de secretários que no passado não teriam ajudado suficientemente a impor o emprego de cenógrafos, por não existirem escolas especializadas para atender as demandas do próprio Municipal. ${ }^{165}$

A própria continuidade no trabalho de formação de novos profissionais capacitados para o exercício do teatro, nas instituições então constituídas como a EAD, passou por certo momento de crise ainda que com a ajuda estatal. Mesmo estando dentro da estrutura da companhia do TBC, Alfredo acabou em 1952 promovendo uma reestruturaçãoaté certo ponto inesperada ao levara nova EAD a se mudar para um espaço próprio na Rua Maranhão, em Higienópolis, onde a escola permaneceu por toda a década de 50 .

A mudança de endereço da EAD não mudou a parceria de ambas em relação ao desenvolvimento do teatro, afinal os exames finais das turmas ainda eram realizados dentro do espaço do TBC. Além disso, assim como o trabalho na crítica teatral paulista de Décio de Almeida Prado, um dos professores da EAD, acabou por ajudar na consolidação do TBC como pedra basilar do teatro moderno paulista e brasileiro, os movimentos do teatro da Bela Vista eram seguidos também pela crítica do Rio de Janeiro; Assim, novas possibilidades de leitura sobre o TBC estavam crescendo junto do teatro.

Associação Brasileira de Empresários Teatrais, a Associação Paulista deCríticos Teatrais, a Associação de Cronistas Teatrais de Pernambuco, entre outras. In: CAMARGO, 2017, p.170

${ }^{165}$ CALVO, Aldo. A Cenografia do TBC: Minha Experiência de Trabalho. In: SECRETARIA DE ESTADO DA

CULTURA, Cenografia e Indumentária no TBC: 16 anos de História (1948-1964). São Paulo, 1980, p.27 
Em São Paulo, o TBC era citado pela imprensa normalmente de forma polarizada, com o teatro defendido por Décio em O Estado de S. Paulo e Miroel Silveira tecendo críticas maiores na Folha da Manhã - a revista Anhembi, considerada elitizada $^{166}$, se dizia mais imparcial mas também tecia críticas consideravelmente fortes à atuação do TBC. A repercussão em outros veículos parecia muito menor em São Paulo do que na mídia do Rio de Janeiro, não apenas no formato da crítica tradicional a crítica paulista ainda era mais afeita à escola francesa de escrita, enquanto a carioca valorizava outros aspectos da mesma forma que se fazia nos Estados Unidos -, mas na diversificação dos conteúdos em veículos considerados menores que contribuiriam muito para a visão sobre o TBC.

Com isso, além de dar novos horizontes para os envolvidos no TBC saírem de seu prédio na Bela Vista para outros projetos, peças do próprio TBC passaram a ir com mais frequência para o Rio de Janeiro e outras cidades do país. Havia desde meados de 1951 uma intenção em se abrir uma filial carioca para o teatro, visto o grande interesse que o público carioca de teatro demonstrava em relação às montagens, instigado tanto pela crítica especializada local como pelas revistas de variedades que construíram um certo culto às personalidades dos integrantes daquele teatro no imaginário do público. Zampari chegou a declarar em 6 de março de 1951 para o crítico Brício de Abreu, do Diário da Noite, sobre condições para que o seu grupo de artistas pudesse se apresentar no Rio:

\begin{abstract}
Não está fora de nossas cogitações levar ao Rio o nosso elenco, mas isso apresenta grandes dificuldades. Primeiramente, meu ponto de vista de empresário é preocupado com o conforto dos artistas, em que o hotel hospeda-los, uma vez que com preço exorbitante que pedem, a despesa seria enorme e refletiria no preço que teríamos de cobrar. [...] O ideal seria um teatro onde já houvesse um hotel, mas quando isso existe, o preço não permite uma temporada senão a preços elevados, criando outro problema para resolver.
\end{abstract}

Sob essas condições, a primeira vez do elenco no TBC no Rio de Janeiro se deu logo em novembro de 1951, com o Teatro Municipal cedido pela prefeitura para uma programação que incluía “A Dama das Camélias", peça programada para o aniversário da companhia. Porém, Brício de Abreu teceu longa série de críticas ao que considerou uma falta de organização da turnê, que teria levado ao Rio algo aquém do que demonstrariam em São Paulo, e o que próprio destaque dado a Cacilda Becker não seria

\footnotetext{
${ }^{166}$ Cf. em: ABDALA-MENDES, Marta Ferreira. Reflexões históricas sobre a Revista Anhembi: A relação entre política científica, ciência e cultura. São Paulo: PUC, 2015
} 
"mérito da companhia", por ela já ter se tornado profissional antes de ingressar nela, evidenciandofalta de apoio futuro de entes públicos e da imprensa local a novas turnês.

Aparentemente, os atores ainda não haviam conseguido se acostumar a um palco de proporções maiores que o do $\mathrm{TBC}$, pois os problemas já haviam ocorrido na montagem no Municipal de São Paulo poucos dias antes, com “(...) poucas vozes (indo além do) poço da orquestra, a maioria não chegava à platéia com a pujançanecessária para que o público se integrasse àssituações trágicas desenvolvidas no palco" ${ }^{\text {"167. }}$. Luciano Salce, tendo iniciado seu trabalho com o grupo após vir da Vera Cruz, conseguiu trabalhar melhor essas questões quando a montagem foi ao palco do teatro da Bela Vista.

Essas questões, mais do que causar obstáculos para o trabalho do TBC, pareciam dar asas a novos planos. A intenção de ter maior intercâmbio com o teatro feito no Rio de Janeiro, que já havia iniciado no período amador do teatro, parecia pronta para se intensificar para o TBC contribuir ainda mais em elevar o padrão do fazer teatral brasileiro. Além do mais, muitos dos seus contratados tinham experiência anterior ao TBC na cidade, e dessa forma as questões do poder público pareciam aparentemente não lhes dizer tanto respeito. Além do suporte da SBC, o teatro tinha, desde o tempo de ocupação do teatro pelos amadores, um estabelecimento comercial tradicional na cidade como o anunciante mais fiel e constante em seus programas: a Casa Bento Loeb, loja de artigos selecionados sediada na Rua Direita quando fundada em 1911, e desde muito tempo estabelecida na Rua Quinze de Novembro onde recebia seus clientes em busca de jóias finas e artigos de arte.

Apesar disso, Zampari tambem se voltou pouco antes a apagar novos focos de incêndio entre os contratados que pareciam diminuídos desde o início da composição da companhia. Após a tensão na temporada de "Entre Quatro Paredes" que terminou de forma positiva, a primeira movimentação das peças na equipe fixa do TBC se deu já em maio de 1950, após montagem de "Ronda dos Malandros", de John Gay, por parte de Ruggero Jacobbi. Ele utilizou elementos de Cruz de Souza para localizar a peça no contexto brasileiro, e para deslocá-lo do momento de então, além de citações a Bertolt Brecht. A versão da peça feita pelo próprio Brecht não teria sido levada ao palco por

${ }^{167}$ LÍCIA, 2007, p.279 
Jacobbi para que os problemas de censura com a peça de Sartre não se repetissem. Porém, os conflitos internos de Jacobbi com a direção da SBC para manutenção da temporada acabaram explodindo mesmo assim, com reações externas ao TBC vindas por intervenções de Décio de Almeida Prado na imprensa a falar que a peça era "ruim", e Sábato Magaldi colocando que ela simplesmente "fracassou"168 em transmitir suas intenções.

Mas o fato é que com seis mil pessoas tendo visto a peça em dezenove apresentações antes do brusco fechamento da montagem, quase a lotação completa do teatro no período - a peça teve a maior média de público do TBC até então, com $86 \%$ da ocupação -, havia indícios para considerar esta como uma interferência política de Zampari e da direção da SBC para que se sacramentasse a decisão de interromper a temporada. Para isso, pode-se perceber o sentimento carregado nas palavras do próprio Ruggero Jacobbi usadas como justificativa para ele haver pedido sua demissão, face o cancelamento da peça:

Foi no dia 22 de Maio que apresentei minha demissão do cargo de ensaiador do TBC. Na mesma ocasião, devido às ligações do TBC com a companhia Vera Cruz, demite-me também desta entidade. A origem de minha demissão reside exclusivamente no fato de ter sido ordenada naquele mesmo dia 22 , e sem que ninguém se desse a pena de me consultar, a retirada de cartaz da peça "A Ronda dos Malandros" de John Gay, por mim dirigida. Isso apesar da ausência do diretor artístico do teatro, Adolfo Celi, apesar da peça ter dado perto de 144 mil cruzeiros nos primeiros 5 dias, apesar dela constituir a volta do TBC a um repertório de arte. Houve evidentemente algum outro motivo que conseguiu influenciar a honesta ingenuidade de empresários inexperientes. ${ }^{169}$

Era fato, porém, que Jacobbi tinha muitos planos e projetos para se preocupar em continuar atrelado ao TBC. Antes de sair, ele já havia feito dois filmes em $1951 \mathrm{com}$ a Companhia Maristela no Rio - "Presença de Anita" e "Suzana e o Presidente" - e proposto à protagonista desses filmes, Vera Nunes, de formar uma parceria para uma futura companhia teatral. Essa parceria levou "Presença de Anita" para o Teatro Cultura Artística ainda em 1951. Além disso, Jacobbi foi chamado para uma remontagem no Teatro Municipal de uma peça infantil dirigida por ele no Teatro dos Doze, ainda com

\footnotetext{
${ }^{168}$ GUZIK, Op. Cit., p. 40; Revista Dionysos, 1980, p.45

${ }^{169}$ Entrvista para Miroel Silveira publicada na revista Radar de 2 de junho de 1950, in: Revista Dionysos,1980, p.194
} 
Sergio Cardoso no papel principal. Com patrocínio da Secretaria de Cultura na remontagem, Zampari acabou sendo obrigado a ceder para que Jacobbi e Cardoso participassem. ${ }^{170}$

Foi a primeira vez que Zampari teve de ceder alguém ligado à sua companhia para um trabalho alheio a ela, sem que o trabalho para o qual cederia seus contratados houvesse sido representado primeiro em seu teatro. Isso faz pensar que seu comportamento com Jacobbi tenha sido exacerbado por essa percepção de falta de controle sobre seu trabalho, por este levar tantos projetos paralelos ao TBC que não diziam respeito ao seu trabalho realizado no local. Tais conflitos levaram então à ruptura de Jacobbi e Zampari naquela ocasião. Mas como ele, da mesma forma que muitos no TBC, tinha também contrato com a Vera Cruz para produção de contéudo, pensou-se uma possível solução para o impasse.

O acordo entre eles, explicitado pelo próprio Jacobbi no Correio Paulistano de 25 de maio de 1952, previa que em caso de remontagem de alguma peça anteriormente dirigida por ele, Jacobbi seria chamado de volta com um contrato específico para tal trabalho. Isso aconteceu naquele mesmo ano de 1952 quando "O Mentiroso", montado por ele ainda na fase amadora do TBC, foi programado para ser reapresentado no próprio teatro. Além disso, ele falou na matéria desse jornal a respeito de planos que tinha expressado a Zampari para fazer sessões especiais, que chamou ali de Teatro das Segundas-Feiras. O projeto não teria a participação de Jacobbi em seu início, pois este estava comprometido com peças de teleteatro encenadas na nascente TV Tupi no momento em que Zampari encampou o projeto, e Jacobbi alegava ter contrato fixo com a emissora para trabalhar exatamente às segundas-feiras.

Apesar da aparente estabilidade e satisfação do corpo de atores e diretores ao longo dos anos, esse episódio mostra alguns dados que evidenciavam um padrão de comportamento que se repetiria ao longo dos anos 1950 e parecia escapar ao controle de Zampari na condução do TBC. Havia ao mesmo tempo uma ambição e condução estéticas de artistas da companhia que poderiam não condizer ao que Zampari e a Sociedade Brasileira de Comédia esperavam. Também as ligações afetivas e/ou profissionais entre estes e outras pessoas da companhia acabavam alimentando desejos

${ }^{170}$ LÍCIA, 2007, p.154 
de emancipação que dificilmente eram contidos em nome do profissionalismo e do comprometimento da equipe com o cada vez mais amplo projeto cultural do TBC.

Mesmo atores consolidados dentro da estrutura do TBC se queixavam de certa maneira com o fato de dividirem seus afazeres entre as diferentes linguagens. Sergio Cardoso, em entrevista para o Correio Paulistano em outubro de 1952, além de falar dessa dificuldadede adaptação, tambem lamentava que a atividade intelectual e artística no Brasil ainda não seria "financeiramente satisfatória" a não ser que se corresse "(...) do palco para a boate, daí para o estúdio de televisão, deste para a estação de rádio e depois de enfrentar o microfone, ainda ter tempo e saúde para posar diante de uma câmera de cinema." Mesmo com isso, ele também acabaria procurando trabalhos paralelos no teatro a partir dali.

Há de se ressaltar que essas insatisfações e rupturas não eram definitivas e que os trabalhos dos grupos próprios e do TBC poderiam também coexistir. Os exemplos de Jacobbi e Madalena Nicol, os primeiros a saíremdo TBC profissional, são ilustrativos quanto a isso. Eles chegaram a formar uma companhia teatral própria ainda em 1951, quando Madalena já estava fora do TBC, e prosseguiram o trabalho conjunto de maneira esparsa até 1954 . No período, chegaram a realizar trabalhos avulsos para a Vera Cruz e o próprio $\mathrm{TBC}$ - Madalena recebeu convites para participação na implementação do projeto do Teatro das Segundas-feiras e Jacobbi ainda considerava filmar com a Vera Cruz, não pensando em projetos teatrais no momento pelos outros compromissos assumidos.

Curiosamente, foi a partir da saída de Jacobbi que Ziembinski foi finalmente convidado a participar do TBC. Ele passou a colaborar ainda em 1950 inicialmente em três montagens independentes da companhiacomo responsável junto a Luciano Salce, este ainda em paralelo ao seu trabalho na Vera Cruz, e Guilherme de Almeida, conselheiro literário do teatro,pelo experimento do Teatro das Segundas-Feiras aos quais o TBC se permitiu fazer a mescla de profissionais e amadores como na origem do teatro, possibilitando um trabalho de maturação de atores ao realizar sessões especiais de peças de um ato às segundas-feiras. Após quatro semanas de apresentações, Ziembinski foi convidado por Zamparia participar do grupo de diretores contratados, no momento em que Celi estava comprometido com trabalhos na Vera Cruz. 
Depois da volta ao TBC a convite de Ziembinski em 1951 com a peça "Grilo da Lareira", de Charles Dickens, Paulo Autran também ajudou na entrada no TBC daquela que o levou ao profissionalismo nos palcos. Tônia Carrero havia dito em agosto de 1953 que assinaria para fazer filmes na Vera Cruz se estivesse no contrato uma cláusula que garantisse sua participação no teatro, mesmo que fosse preciso fazer uma companhia própria. Mas esse último movimento não foi necessário, pois ela fez ainda em dezembro de 1953 a peça "Uma Certa Cabana", sua primeira peça com Autran nesse teatro. Esse tipo de conflito entre trabalhos para o TBC e a Vera Cruz já haviam tirado o casal Ruy Affonso e Elisabeth Heinreid em 1952. Ela fazia filmes regularmente para a produtora, enquanto ele queria assumir alguma direção para continuar no teatro. Zampari the ofereceu a direção do setor de roteiros na Vera Cruz e sua pronta recusa o afastou em definitivo de Zampari.

Nesse ponto de alta concentração de trabalhos em poucas pessoas, a situação dos chamados "colaboradores" começava a se tornar mais delicado o pretenso equilíbrio dentro da companhia, seja na equipe artística como na técnica. Antunes Filho, por exemplo, começou seu trabalho no TBC vindo do Teatro da Juventude como assistente dos diretores estrangeiros com uma proposta de receber mil cruzeiros ao mês. Trabalhando com Flamínio Bollini Cerri em "Vá com Deus" em 1952, e em outras peças posteriormente com Ziembinski, Antunes disse ter aprendido muito a fazer um processo de pesquisa para montagens, alem de entender o rigor desses diretores para com os artistas brasileiros. Porém, ele também lamenta que em dois anos não tenha formalizado um contrato com o $\mathrm{TBC}$, alegando sequer ter recebido o ordenado proposto. $^{171}$

Antunes também estranhou o que viu como um certo ranço daquele teatro com autores e diretores brasileiros. Um dos trabalhos feitos com Ziembinski seria uma montagem de "Senhora dos Afogados", de Nelson Rodrigues, que ele diz não ter sido encenada pela SBC “(...) não ter acreditado na sua viabilidade econômica" 172 . Assim como autores, dizia que a direção nacional não era incentivada por "ordens de cima", mesmo no espaço mais experimental do Teatro das Segundas-Feiras. A recíproca de alguns autores nacionais contra diretores estrangeiros parecia verdadeira pois, segundo

${ }^{171}$ Entrevista à revista Dionysos, 1980, p.140

172 GUZIK, 1986, p.83-4 
Jacobbi, Nelson Rodrigues teria recusado uma proposta sua para dirigir "Vestido de Noiva" após este sair do TBC por considerá-lo "analfabeto em vários idiomas"173, como se não aceitasse suas ideias como diretor.

Por causa de companhias como o TBC, que aos olhos dos gestores públicos priorizavam apenas o trabalho de estrangeiros em nome do desenvolvimento do teatro, o projeto do Estado Nacional representado por Getúlio Vargas se fez novamente presente dentro da cena teatral brasileira. As resoluções do $1^{\circ}$ Congresso Brasileiro de Teatro então se concretizaram em 1953 em três movimentos convergentes. O primeiro deles foi a criação do Ministério da Educação e Cultura (MEC), separando atribuições que antes eram sobrepostas por demandas complexas e variadas às quais esteve sempre atrelado.

Também deu-se direcionamento à reedição da companhia estatal do primeiro governo de Vargas em uma nova Companhia Dramática Nacional (CDN), que seria dirigida por Aldo Calvet e Henrique Pongetti, com a intenção de também ser um centro de formação. Se os trabalhos do novo Ministério continuavam restritos ao atendimento de demandas pontuais, sem que houvesse um plano estabelecido a ser implementado em nível nacional, os trabalhos da nova Companhia Dramática começavam bem ao assimiliar novos diretores nacionais entre atores proeminentes que haviam feito algum experimento anterior na área. Assim, Bibi Ferreira e Sergio Cardoso foram chamados a dirigir para a CDN outros atores convidados do porte de Sonia Oiticica e Leonardo Vilar. Sergio Cardoso e Nydia Lícia, casados e buscando novos ares no Rio de Janeiro, aumentaram assim a lista de desfalques do TBC. A cenografia prometia também “(...) competir em igualdade de condições com o TBC"174.

A terceira ação, que acabaria por ter mais impacto que as anteriores no trabalho de companhias como o TBC,foi a instituição da Lei Federal N.1565, de 3 de março de 1952, que ficou conhecida como "Lei 2 por 1" que dizia que toda companhia de teatro tinha de obrigatoriamente incluir um texto de autor nacional após encenar duas peças estrangeiras em um ano.Tal lei valia tanto para estabelecimentos privados como para companhias que alugam outros teatros fora de suas sedes. Mas a Companhia Dramática Nacional se antecipoua qualquer fiscalização oficial sobre sua conduta a respeito da lei

\footnotetext{
${ }^{173}$ Declaração de Nelson Rodrigues transcrita em matéria do jornal Correio Paulistano em maio de 1952. Cf na p. 118-9

${ }^{174}$ MICHALSKI; TROTTA, 1992, p. 106
} 
ao anunciar desde o início que seu repertório seria exclusivamente nacional. De certo modo, esse movimento podia ser tomado como boa novidade para o cenário teatral.

No entanto, isso esteve longe de ser uma unanimidade. A própria implantação da companhia foi cheia de problemas, pois a estreia estava programada para março de 1953. O adiamento ocorreu por fortes questionamentos quanto à destinação de verbas do SNT para a companhia. Primeiro, o pedido original aprovado pelos presentes ao Congresso Brasileiro de Teatro seria para que esta nova companhia fosse composta inicialmente por amadores. Isto não foi considerado em emenda votada no Congresso Nacional em novembro de 1952 que pedia a quantia "embora modesta" de dois milhões de cruzeiros para a composição do grupo. ${ }^{175}$

Após impasse de quatro meses, com idas e vindas nas instâncias de governo adiando a estréia da companhia, fica acertada metade da verba anterior (um milhão de cruzeiros) com a promessa de trazer os profissionais, com salários altos para o mercado - Bibi Ferreira, o maior salário da $\mathrm{CDN}$, receberia vinte e dois mil cruzeiros para trabalhar na direção de espetáculos. Campanha contra a CDN liderada por Jayme Costa consegue chegar a Getúlio com questionamentos ao SNT sobre a viabilidade de fazer teatro "experimental" com profissionais, trazendo "(...) concorrência às companhias privadas" ${ }^{176}$ para algo que poderia ser feito por alunos do Curso Prático de Teatro,.

Com o conhecimento dos questionamentos de Vargas ao projeto aprovado no Congresso Nacional vindo a público, é articulado a partir de São Paulo um grande movimento de artistas dando apoio à implantação da nova CDN. Entre eles estavam Cacilda Becker, Ziembinski Abilio Pereira de Almeida, Tônia Carrero, Paulo Autran, Sergio Britto, além de Procópio Ferreira, Ítalo Rossi e outros. Procópio Ferreira escreve a Paschoal Carlos Magno, então presidente do TEB (Teatro do Estudante do Brasil) ${ }^{177}$, endossando o apoio do grupo a projetos anteriores implementados ou apoiados por Vargas, ao mesmo tempo que espera novas políticas aos que necessitam:

\footnotetext{
${ }^{175}$ Ibid., p. 74-8

${ }^{176}$ Publicado no jornal O Globo de 19 de maio de 1953, in: MICHALSKI; TROTTA, 1992, p. 76

177 Paschoal Carlos Magno, como diretor de grupos de teatro estudantil no Rio dos anos 1930 e 40, e posteriormente do TEB, construiu uma rede que se estendeu pelo país e permitiu que sua atuação passasse por vários governos, fazendo dele interlocutor importante quanto á políticas públicas para o teatro. Cf.mais em: FONTANA, Fabiana Siqueira. VI Congresso de Pesquisa e Pós-Graduação em Artes Cênicas ABRACE. O Acervo Paschoal Carlos Magno e novas perspectivas para a análise do teatro brasileiro moderno. Campinas:Unicamp, 2010
} 
Jayme Costa, Delorges Caminha e também Francisco Moreno, assim como eu, não tivemos a ventura de encontrar no início de nossa carreira o amparo oficial. Lutamos sozinhos para criar um teatro que no futuro viesse a merecer a atenção dos poderes públicos. Se desde o início desejamos esse amparo, seria injustiça de nossa parte nega-lo hoje aos jovens que tão bem o merecem. [...] Duvido que Francisco Moreno, a quem eu quero tanto bem, possa se esquecer que, como presidente da Casa dos Artistas, representa todos nós, principalmente os novos a quem deve pela responsabilidade de seu cargo todo o apoio moral. É com imenso orgulho que eu, velho profissional de teatro, que já tinha para com Sua Excelência, o presidente Getúlio Vargas, uma divida de gratidão por ter dado à minha classe uma carteira profissional com a lei que leva o seu nome, é com orgulho que vejo esse grande estadista amparar a nova geração facilitando-lhes os primeiros passos. ${ }^{178}$

Com esse apelo conciliatório, bradando à possibilidade de que a CDN pudesse abarcar tanto jovens amadores, oriundos de escolas de teatro, como os profissionais a que se queria contratar como chamarizes de público e respaldo para dar maior importância à companhia, Getúlio Vargas acaba em 23 de maio por permitir a concessão de um milhão de cruzeiros para a composição e estreia da companhia, ocorrida menos de um mês depois da resolução com "A Falecida”, de Nelson Rodrigues em 5 de junho de 1953. Até então, quatrocentos mil cruzeiros já haviam sido dispendidos por dotações de verba complementar, retiradas do próprio SNT, fazendo com que, mesmo após a concessão anterior, Vargas se mantivesse contrariado com a condução da empreitada.

As críticas não pararam por aí. Ensaio publicado no Correio Paulistano em 20 de setembro de 1953 ainda colocava dúvidas sobre o quanto a CDN, chamada "Comédia Brasileira" pela imprensa para contrapô-la ao TBC, poderia se tornar uma companhia estável e que contribuísse no crescimento dos artistas que dela fizessem parte. Esse ensaio tambem questionava o nível dos dramaturgos nacionais, que “(...) fazem um texto que de nacional tem só o nome.” As críticas se ligam ao fato de que, no período inicial de aplicação da referida "Lei 2 por 1", ela era cumprida com a programação de autores contemporâneos que traziam elementos anacrônicos ou herméticos demais para o público médio que buscava atingir. Isso ocorreu na própria $\mathrm{CDN}$, que encenou autores como Guilherme Figueiredo e Raymundo Magalhães Júnior, cujas obras integravam a estreia e tratavam de temas clássicos sem atualização local e contemporânea.

${ }^{178}$ MICHALSKI; TROTTA, Op. Cit., p. 77 
No caso do TBC, a nova lei parece não ter atingido de imediato a programação da casa. Após a verdadeira epopeia para se colocar no mesmo programa duas versões de “Antígona" dirigidas por Luciano Salce em 1952, com Cacilda Becker e Paulo Autran como protagonistas na junção dos textos de Sófocles e Jean Anouilh, celebradas por críticos como Décio de Almeida Prado como "o maior espetáculo do TBC",179, o TBC montou uma produção ainda maior para "Na Terra Como no Céu", de Fritz Hochwalder, em junho de 1953. Enquanto nas “Antígonas" os atores faziam as mesmas funções nas duas versões, desta vez Luciano Salce usou o maior elenco de atores em uma só peça no período profissional do teatro, colocando vinte e oito atores em cena.

No programa de "Na Terra Como no Céu", informes sobre a Vera Cruz mostravam que, tal como o TBC, ela vinha experimentado grandes tombos mas tambem sucessos inéditos para a indústria cultural brasileira. Os informes falavam sobre presença de Franco Zampari na convenção da distribuidora Columbia Pictures em Barcelona, onde conseguiu garantir distribuição internacional dos filmes "Tico-Tico no Fubá", "Sinhá Moça" (protagonizado por Ruth de Souza, atriz oriunda do Teatro Experimental do Negro no Rio de Janeiro) e aquele que seria o maior êxito da companhia: "O Cangaceiro", de Lima Barreto, com prêmio especial em Cannes consolidando uma imagem nacional ao exterior junto a uma grande afluência de público. Ainda assim, o ano de 1953 prenunciava ser o de maior déficit da companhia, pois ela nitidamente não conseguia saldar suas dívidas anteriores com o que arrecadava com os filmes de carreira mais longa nas salas - basicamente o mesmo problema do TBC, que naquele ano subiu o preço dos ingressos de sessenta para oitenta cruzeiros.

Com Cleyde Yáconis finalmente assumindo um papel de maior importância em “Assim É...Se Lhe Parece”, de Luigi Pirandello, com Adolfo Celi na direção, ela assim deixa definitivamente o guarda-roupa para Zoraide Grego Dihel, funcionária que se tornaria a mais longeva do teatro.Depois disso, a diretoria do teatro deu um jeito decumprir a cota nacionalem 1953 ao receber uma companhia iniciante do Rio de Janeiro, a Armando Couto-Loudy Veloso (composta apenas por eles próprios) para encenar Millôr Fernandes, que apresentava seu texto "Uma Mulher em Três Atos" com o pseudônimo Vão Gogo.

\footnotetext{
${ }^{179}$ Revista Dionysos, 1980 , p. 46
} 
Inicialmente escalada para o Teatro das Segundas-Feiras, a produção foi custeada completamente pela dupla carioca de atores, que pagou inclusive o trabalho da equipe técnica e a direção de Adolfo Celi como uma aposta própria de que seu texto de humor poderia ser um sucesso. E de certa forma, a obra alcança um objetivo maior do que sugeria num primeiro momento, passando para uma temporada regular de quarenta e duas apresentações para oito mil pessoas - $55 \%$ da lotação das sessões. Nesse sentido, contrapõe-se às "Antígonas", que em setenta e duas sessões levaram treze mil ao teatro - quase $50 \%$ dos assentos -, abaixo da média para montagens de maior ambição estética. $^{180}$

Colocar uma peça de “(...) bilheteria garantida contra o (fracasso do último) projeto mais ambicioso" 181 parecia ter se tornado um padrão adquirido pela casa. Mas esse pensamento não parece ser leitura de uma estratégia consciente da diretoria do TBC. Afinal, havia ainda grande resistência ao texto nacional, e muito possivelmente a montagem da companhia carioca só foi aceita por não trazer acréscimo de custos à SBC. Esta era apenas a sexta companhia profissional convidada até ali - as outras vieram com Ziembinski, Aimée, Vittorio Gassman, Robert H. Eagling e Madalena Nicol - e a primeira que alugara o teatro para montagem própria desde a consolidação profissional do teatro. O caso de "Uma Mulher em Três Atos" acabou sendo uma revelação de uma tendência auma maior valorização do público ao TBC quando este buscava celebrar o autor nacional.

No Rio de Janeiro, esse movimento pareceu mais evidente, pois a peça teve sua estreia nacional em São Paulo, e ao ser encenada no Teatro de Dulcina de Moraes no Rio, conseguiu com a repercussão positiva obtida em São Paulo render, segundo o jornal Correio da Manhã de 13 de abril de 1954, trezentos mil cruzeiros em sua estreia carioca. Pensando no âmbito promocional para além da busca pelo apuramento estético, tais esforços da crítica e da imprensa em geral foram bem sucedidos ao exaltar encenações como essas como um fôlego novo para o teatro nacional. Tal promoção do TBC entre o público carioca animou Zampari a por em prática o plano que havia pensado ainda em 1951, quando da primeira turnê para o Rio de Janeiro.

\footnotetext{
${ }^{180}$ Trata-se daqui por diante como "média" a ocupação de $50 \%$ dos assentos em todas as sessões. ${ }^{181}$ GUZIK, 1986, p. 86
} 
Em setembro de 1954, houve então a concretização de uma nova campanha de sócios do TBC no Rio de Janeiro para garantir as apresentações do TBC na cidade, com o Teatro do Real Clube Ginástico Português vendendo lugares para assinantes com a promessa de que ao menos seis peças seriam apresentadas ali, entre elas peças já montadas em momentos anteriores na cidade de São Paulo e que fariam temporadas de quinze dias em média no Rio de Janeiro. E isso acontece de fato a partir de então, com “Assim É...Se Lhe Parece” marcando presença com o elenco completo da companhia, para não haver as reclamações da primeira turnê pela ausência de Sergio Cardoso.

Zampari mencionou ter esperanças de que essa medida faria com que mesmo os textos "artísticos" pudessem "chegar a dar lucro."182 Tal sentimento foi seguido por Guzik ao teceruma justificativa pertinente para Zampari colocar o seu investimento na então capital federal, algo visto como uma boa válvula de escape para a companhia:

Em princípio ao menos, o raciocínio que leva o conjunto a se
fixar no Rio de Janeiro é perfeito. Diante do considerável
número de produções que possui em seu repertório, não se trata
de envidar esforços para o deslocamento de capital objetivando
novo investimento. Parece a Zampari que apresentar os
espetáculos do grupo no Rio é uma forma de ampliar sua
rentabilidade. [...] Se uma montagem determinada pagar sua
produção em uma das cidades, a receita de bilheteria na outra
representará benvindo lucro. A instalação da sucursal do Rio é
a culminação de uma inversão que levara longos anos se
processando (em que) o teatro de São Paulo evoluíra o
suficiente para exportar sua produção para o Rio. ${ }^{8}$.

Junto dessa estreia no Ginástico, também aconteceram durante a temporada na cidade leituras da "Antígona" de Sófocles promovidas por patrocínio do MEC. Tais patrocínios para ações pontuais feitas pelo poder público parecem levados a entidades como o TBC como compensação ao fato da companhia não ter concorrido ou sido contemplada nos editais que o SNT volta a promover a partir de 1953. Nesses novos editais, as companhias concorrentes ao subsídio eram avaliadas e classificadas por critérios mais técnicos e menos subjetivos que em 1939, quando instituídos pela primeira vez, baseando-se em diferentes níveis de categorias e condições de auxílios

\footnotetext{
${ }^{182}$ Revista Dionysos, 1980, p. 100

${ }^{183}$ GUZIK, 1986, p. 109
} 
onde figuravam informações como repertório e elenco, exigências legais e, em alguns casos, questões artísticas avaliadas pelo Conselho Consultivo de Teatro. ${ }^{184}$

No mesmo período, Ruggero Jacobbi voltaria a uma tentativa de trabalho regular com o TBC $^{185}$ ao buscar replicar, por sugestão de Paschoal Carlos Magno, a experiência buscada com as peças às segundas-feiras com o Teatro de Vanguarda. Ao escolher treze intérpretes entre alunos do curso de arte dramática do Centro de Estudos Cinematográficos, órgão subvencionado pela Prefeitura dirigido por ele ${ }^{186}$, para representar a peça de estreia do projeto (“A Desconhecida de Arras", de Armand Salacrou), Jacobbi centrava seu trabalho em amadores convidados buscando que eles com o tempo assumissem funções nas sessões principais - um deles foi o estreante Walmor Chagas, o único a ter tido vida longa na companhia a partir dali. O projeto, porém, acaba interrompido após essa primeira experiência por questões comerciais prementes enfrentadas pela SBC, principalmente referentes à Vera Cruz.

Jardel Filho, considerado o principal ator da Vera Cruz a não ter experiência com o teatro, chegou a ser escalado no TBC para estrelar "Leito Nupcial", de Jan de Hartog, no início de 1954. Cacilda Becker também voltou ao teatro logo após filmar "Floradas da Serra" com Jardel Filho, para não perder o vínculo com o teatro. Esse movimento causou um cisma dentro da estrutura do próprio $\mathrm{TBC}$, pois a decisão de levar a cabo a montagem de "Leito..." a ser dirigida por Luciano Salce, passaria por cima da programada temporada de "Uma Certa Cabana" que havia iniciado há pouco, em dezembro de 1953, com Adolfo Celi dirigindo uma bem sucedida montagem com Paulo Autran e Tônia Carrero, então em sua estreia no TBC, que pelo ineditismo da presença de Tônia Carrero arrastava multidões ao teatro. A decisão da diretoria do TBC foi alugar por um período o Teatro Leopoldo Fróes de São Paulo ${ }^{187}$ para a continuidade da temporada de "Uma Certa Cabana".

\footnotetext{
${ }^{184}$ CAMARGO, 2017, p. 175

185 Jacobbi havia feito a direção de "Treze à Mesa” em 1953, peça a qual segundo seu assistente Antunes Filho sentia que"(...) ele ia levando, dormia um pouco no canto, e tudo bem"; in: RAULINO, 2002, p. 147 ${ }^{186}$ Ibid., p. 158

187 Teatro pertencente à Prefeitura na Vila Buarque, era chamado de Teatro Infantil por ficar junto à Biblioteca Infantil Municipal (hoje Monteiro Lobato), destinada ao público infanto-juvenil. Foi demolido no início dos anos 70. Cf. em: LOUREIRO, Edison. Uma lembrança da Biblioteca Infantil. In: São Paulo Minha Cidade, 21 de março de 2016, in: <https://saopaulopassado.wordpress.com/2016/03/21/umalembranca-da-biblioteca-infantil/> Acessado em 07 de Agosto de 2019
} 
Por muito tempo, se colocou que essa separação em dois espaços físicos teria a ver com questões pessoais envolvendo Celi e Becker, e mais tarde a própria Tônia Carrero, em ciúmes mútuos pelo protagonismo dentro do TBC. Há, no entanto, uma hipótese mais provável de que o movimento de acomodação brusca dos artistas com vínculo de trabalho com a Vera Cruz dentro do TBC foi para que não houvesse maiores contestações em relação à possiblidade de não serem pagos, se continuassem sob contrato com a Vera Cruz - vale lembrar que ambas as companhias tinham caixas separados apesar de administrados por muitas pessoas em comum, incluindo o próprio Zampari.

Os caixas das duas empresas, entretanto, mostraram não serem assim tão separados. Após a temporada de "A Ronda dos Malandros" interrompida por Zampari, o diretor artístico da Vera Cruz, Alberto Cavalcanti, que tinha um contrato de quatro anos com a empresa, reportou uma saídade trezentos mil cruzeiros da Vera Cruz para cobrir despesas do TBC. Apesar dos pedidos para que isso não mais acontecesse ${ }^{188}$, é bastante possível que essa prática tenha continuado dali por diante. Isso parece ter resultado no pedido de demissão de Cavalcanti em agosto de 1952, de onde ele ajudou a partir dali na implantação da Comissão de Cinema pretendida pelo governo para formular as políticas públicas federais para a área audiovisual ${ }^{189}$.

A questão é que a Vera Cruz já havia tomado vários empréstimos junto ao Banco do Brasil e ao BANESPA para continuidade de suas produções, e com reiterados problemas no pagamento desses empréstimos, a Vera Cruz se viu em uma contínua tensão. Durante o ano de 1953, ela enfrentou severos problemas de manutenção, com “(...) funcionários demitidos e outros que aguardavam saber sua situação (enquanto ocupavam) sets vazios de gente, onde continuavam montados os últimos filmes em produção." ${ }^{190}$ Apesar da paralisação, os sets de filmagem não eram desmontados por se aguardar uma posição oficial que levou algum tempo para aparecer. Principalmente os técnicos estrangeiros da empresa eram os que mais aguardavam ao menos concluir seus trabalhos.

\footnotetext{
${ }^{188}$ Segundo entrevista de Cavalcanti para Maria Rita Galvão, apud GUZIK, 1986, p. 144

${ }^{189}$ Cf. na p. 102

${ }^{190}$ GUZIK, 1986, p. 93
} 
A situação calamitosa forçou a que se fizesse um acordo em abril de 1954 com a presença do ministro Antonio Balbino (do MEC), do governador Lucas Nogueira Guerra e do secretário da Fazenda do estado, Sebastião Paes de Almeida. A comissão extraordinária formada por cinco indicados em sua maioria pelo BANESPA, que tomou as ações do Banco do Brasil se tornando único credor da Vera Cruz, afastou Zampari da direção da companhia como condição para buscar solução de encampação total do patrimônio pelo banco ou por financiamento a longo prazo. Uma assembleia geral com os sócios da empresa um mês depois empossou Edmundo Rossi, indicado do governo do estado, como porta-voz da companhia para colocar a público a situação da empresa.

No TBC, a estratégia de se colocar novos textos nacionais era vista mais como uma estratégia de contenção de gastos do que escolha estética. Para isso funcionar, eles precisariam ser escritos por alguém a quem não precisassem mais pagar pelos direitos ou seja, que não fossem modernos ou contemporâneos - ou que fossem do círculo interno da SBC. No caso da CDN, que havia instituído essa política como norma da casa, isso acabou não sendo algo bem sucedido, pois a companhia estatal acabou fechando no ano de 1954. E a estratégia não tinha apoio entre todos da diretoria da SBC. Guilherme de Almeida dizia no Correio Paulistano de 8 de junho de 1952 que sempre esteve identificado com o TBC por trazer da infância o gosto pelo teatro clássico "levado por grupos franceses à noite no Municipal", sentimento esse que seria representado no "reacendimetno desse amor antigo" por essa estética trazida pelo TBC.

Para críticos como Sábato Magaldi, o TBC sempre tendeu ao ecletismo em suas escolhas, ainda que diferente das companhias profissionais que tinham vindo antes deles, onde os elencos eram conhecidos por gêneros específicos nos quias se especializavam (revista, dramas europeus, modernismo americano), e que no caso do TBC tendia-se a uma “(...) obrigação de satisfazer aos diferentes gostos do público (baseando-se) em equilibrar as finanças" ${ }^{\prime 191}$ através dessa variação entre peças ditas comerciais e artísticas. Entretanto, essa escolha entre tradicionalismo clássico e novos autores nacionais não era um dilema tão grande para alguns artistas que consideravam, dentro do ecletismo que caracterizava o TBC na escolha do seu repertório, essas variações como algo possível de ser comportado pela casa dentro de suas possiblidades.

${ }^{191}$ MAGALDI, 1997, p. 196 
Paulo Autran chegou a declarar no Correio Paulistano em 20 de julho de 1952 que "autores brasileiros estariam demonstrando maior interesse pelos problemas do teatro" buscando cada vez mais "adquirir técnica teatral e resolver problemas literários". Esses elogios parecem ter sido feitos sob medida para exaltar especialmente o texto com o qual trabalhava na época - "Para Onde a Terra Cresce", de Edgard da Rocha Miranda, que acabou sendo conhecida como uma das peças de temporada mais curta na casa. Tempos depois, já em meio às tentativas de redirecionamento da casa frente às crises internas e aos efeitos colaterais da queda da Vera Cruz, Edgard acaba tendo seus caminhos novamente cruzados com os do $\mathrm{TBC}$ de uma maneira inusual para ter um novo texto seu escolhido para ser encenado na companhia.

Ainda em fevereiro de 1953, foi instituída a chamada Comissão de Festejos do IV Centenário da cidade de São Paulo. Apesar de seu caráter oficial junto ao município, sua direção executiva era liderada por aquele que era o grande mecenas privado das atividades culturais da cidade, Ciccillo Matarazzo, também presidente da SBC. Ele convidou para compor a sua comissão de teatro,com o intuito de promover um concurso de peças, os nomes de Ruggero Jacobbi, Alfredo Mesquita e Joraci Camargo. O Prêmio Martins Pena, instituído como parte do concurso, pagaria cem mil cruzeiros ao vencedor e sessenta mil cruzeiros ao segundo colocado, atraindo com isso cinquenta e sete concorrentes de várias partes do país selecionados por essa comissão através de suas obras, inscritas sob pseudônimo para se preservar a impessoalidade.

Pelos títulos das peças concorrentes, podia-se perceber uma grande concentração de temas históricos e de exaltação à terra paulista - "E o Noroeste Soprou", novo texto de Edgard Miranda, estava entre estas -, com algumas poucas peças de gênero entre elas. A comissão julgadora das peças foi formada por Décio de Almeida Prado, Ruggero Jacobbi e pelo carioca Guilherme Figueiredo. Em maio, depois que os votos de todos já haviam sido entregues, Figueiredo contestou o concurso por causa de uma obra sua que não teria sido incluída, escrevendo carta aberta a Matarazzo acusando de que a peça teria se "extraviado" quando de sua aceitação como julgador do concurso. Sem mais polêmicas quanto a isso, a resolução do concurso também não foi simples: não foi concedido o primeiro prêmio a nenhum dos concorrentes por falta de consenso, e apenas o segundo prêmio de sessenta mil cruzeiros foi para "E o Noroeste Soprou". 
Entre as menções honrosas, que tiveram reconhecimento sem receber prêmio, a primeira mencionada foi "Orfeu da Conceição", peça escrita por um então funcionário da embaixada brasileira em Paris, Vinícius de Moraes, que inscreveu sua obra sob o pseudônimo Cândido Isaías. O fato dela ser a primeira a ser citada nesse quesito fez com que se perpetuasse uma narrativa de que a peça teria vencido o primeiro prêmio. A bem da verdade, dentre os jornais cariocas mais conhecidos, o único que menciona os fatos dessa forma é $O$ Globo, sendo que todos os outros jornais cariocas analisados Jornal do Brasil, Última Hora, Correio da Manhã - mencionam corretamente de que a peça apenas foi reconhecida sem que lhe fosse concedido prêmio.

As menções honrosas neste concurso tinham alguma importância pela promessa da Comissão de Festejos de encená-las no TBC, enquanto a vencedora iria para um festival programado para acontecer no Teatro Municipal de São Paulo em julho de 1954, com direção de Luciano Salce, Décio de Almeida Prado e Alfredo Mesquita "Senhora dos Afogados", inclusive, também estava no programa pensado para o Municipal. ${ }^{192}$ Nada disso ocorreu como previsto. Nenhuma das peças distintas pelo concurso foi encenada posteriormente além de "Noroeste...", e somente esta acabou indo ao próprio TBC. Houve uma polêmica na montagem por causa de negociações com Luis Linhares para ser assistente de direção após a saída de Antunes Filho, pois este ainda cobrava do teatro mil cruzeiros devidos. Luis Linhares acabou cedendo na sua reivindicação, e fez o trabalho de assistência em paralelo à sua atuação como ator.

Com o fim das contestações, a montagem de Ziembinski se mostra com um bom acento local a ponto de motivar alguma identificação da crítica paulista e um sinal de evolução em relação ao seu texto anterior. Contudo, o público não se sentiu cativado: enquanto "Para Onde a Terra Cresce" reuniu dois mil e seiscentos espectadores em doze apresentações (duas semanas em cartaz), "Noroeste..." consegue pouco mais de três mil em vinte e nove sessões - uma redução drástica na média de ocupação de 57\% para cerca de $30 \%$. Contudo, por não trazer maiores custos à SBC - a produção no TBC foi paga pelo prêmio vencido por Edgard Miranda -, o trabalho em torno da peça prosseguiu de outras formas, com apresentação bancada pelo próprio autor no Municipal do Rio de Janeiro, e ainda um coquetel promovido por ele entre o elenco do

\footnotetext{
192 Publicado no Diário da Noite de 11 de dezembro de 1953
} 
TBC e a crítica carioca quando do encerramento da temporada em 30 de agosto de 1954. Nesse sentido, o cenário propiciado para a SBC foi o de uma "produção ideal".

Nesse cenário, houve um tempo de preparação razoável para o trabalho que correu em paralelo a este: "Leonor de Mendonça", peça do autor romântico Gonçalves Dias, acaba sendo resgatada por indicação de Ruggero Jacobbi, que escreve texto de exaltação à peça no programa, e preparada para estrear em agosto de 1954 com direção de Adolfo Celi. Tendo feito seis mil espectadores em trinta e quatro sessões - média de pouco menos de $50 \%$-, a peça foi bastante encenada pela companhia em turnês pelo país, sendo oferecida com aval da Comissão do IV Centenário para apresentações subvencionadas por órgãos públicos, como a Secretaria de Estado da Cultura e o MEC.

A performance das peças nacionais ainda não era satisfatória o bastante para a SBC, apenas sendo levadas adiante pela ação de agentes externos a ela. Apesar do Brasil representar uma das nacionalidades com mais textos montados no espaço - pois considerando o ecletismo da companhia, as outras nacionalidades acabavam diluídas nas escolhas técnicas e estéticas dos diretores -, havia uma busca por meios de fazer a cultura de São Paulo se tornar mais cosmopolita e aberta a novidades, fazendo alçar o teatro a um lugar de maior importância na cidade. Porém, nem isso livrou o TBC de acusações como as de Sábato Magaldi para quem, apesar de todos os seus esforços e de outros empreendimentos surgidos naquele período, “(...) o teatro em São Paulo ainda permanecia provinciano, sem condições de competir com o cinema"193.

E de fato, muitos dos cineteatros que abrigavam mais de mil pessoas na primeira metade do século XX para assistir as revistas e espetáculos de entretenimento haviam se transformado definitivamente em salas de cinema, enquanto os seis teatros principais remanescentes do início da década de 1950 na cidade - Municipal, São Paulo, Santana, TBC, e as duas salas do Cultura Artística - comportavam apenas seis mil duzentas e sessenta e quatro pessoas no total. Além disso, apesar da euforia cultural do IV Centenário, os teatros estavam realizando cada vez menos sessões, deixando de abrir às terças e quartas a partir do início de 1955 - o que acarretou o fim do projeto do Teatro das Segundas-Feiras no TBC. Os anúncios de estreia nos jornais eram cada vez menores, quando não escritos de forma protocolar.

\footnotetext{
${ }^{193}$ Publicado no jornal O Estado de S. Paulo de 10 de maio de 1952, in: Dionysos, 1980, p.46
} 
Nesse cenário, o preço do ingresso para se assistir uma peça no TBC continuava alto, ainda que buscasse acompanhar a média salarial. Para se ter uma base, apresentações do Piccolo Teatro de Milão no Teatro Municipal em ocasião do IV Centenário custavam entre dez e vinte cruzeiros. Ainda que tal apresentação possa ter sido feita com preço subsidiado pelo poder público para celebração de uma ocasião especial, o TBC prosseguia desde seu início profissional sendo o mais caro da cidade, com ingressos aumentando de preço a cada dois anos em média. Esse aumento estava muito acima das variações da inflação, porém outro fator deve ser considerado para essa elevação, como se pode ver na tabela a seguir que compara salários e outras variáveis com preços dos ingressos:

\begin{tabular}{|l|l|l|l|l|}
\hline \multicolumn{5}{|c|}{ INGRESSOS TBC x INDICADORES ECONÔMICOS DO BRASIL - 1948 a 1954 } \\
\hline Período & $\begin{array}{c}\text { Ingresso TBC } \\
\text { (Variação) }\end{array}$ & $\begin{array}{c}\text { Salário Mínimo/ } \\
\text { Média salarial SP }\end{array}$ & $\begin{array}{c}\text { Inflação } \\
\text { (Média anual) }\end{array}$ & $\begin{array}{c}\text { Cr\$/Dólar } \\
\text { (Variação/Ano) }\end{array}$ \\
\hline $1948 / 50$ & $\mathrm{Cr} \$ 40$ & $\mathrm{Cr} \$ 380 / \mathrm{Cr} \$ 1142,88$ & $26,4 \%(8,8 / \mathrm{ano})$ & $\mathrm{Cr} \$ 12 / \mathrm{U} \$ 1$ \\
\hline $1951 / 2$ & $\mathrm{Cr} \$ 60(+50 \%)$ & $\mathrm{Cr} \$ 380 / \mathrm{Cr} \$ 1364,12$ & $25 \%(12,5 / \mathrm{ano})$ & $\mathrm{Cr} \$ 14(+15 \%)$ \\
\hline $1953 / 4$ & $\mathrm{Cr} \$ 80(+33 \%)$ & $\mathrm{Cr} \$ 1200 / \mathrm{Cr} \$ 1264,45$ & $46,4 \%(15,5 / \mathrm{ano})$ & $\mathrm{Cr} \$ 19(+35 \%)$ \\
\hline
\end{tabular}

Fonte: DIONYSOS, 1980; MUNHOZ, 1997; CARDOSO, 1971; COLISTETE, 2009; portalbrasil.net

Esse fator a ser considerado nas grandes variações de preço que perpassaram o TBC, e que certamente também fizeram aumentar muito mais os gastos da Vera Cruz, é o fato de que a variação do dólar acabou sendo maior que a da inflação e maior ainda em relação aos salários médios em São Paulo. Por cotar compras e pagamentos de contratos em dólar, Zampari acabou penalizado pelo momento em que o governo federal em 1953 abriu o câmbio do dólar perante o cruzeiro, deixando seu fluxo de variação livre, o que prejudicou sobremaneira compras de equipamento importado por empresas de direito privado, fossem lucrativas ou não, pela perda da real referência de seu valor de mercado.

Considerando que Cardoso $(1971)^{194}$ coloca que esse movimento de flutuação do dólar causa tal efeito, seu pensamento se alia à teoria de John Keynes de que a referência tomada com vista à redução de custos “(...) deve ter sua aceitabilidade generalizada" (CHICK, 1992, p.202), ou seja, ser tomada como padrão pelo maior número de agentes possíveis de uma transação econômica para que ela possa funcionar

194 Cf. em CARDOSO, Roberto Carvalho. A utilização da cotação do dólar para eliminar efeitos da inflação. In: Revista de Administração de Empresas, Rio de Janeiro: FGV, abr./jun. 1971 
com eles - neste caso, entre a entidade privada que comprou o serviço/bem e quem recebe o dinheiro pela operação. Esse padrão de se tomar o dólar como parâmetro internacional para operações financeiras foi apresentado pelo próprio Keynes na Conferência de Bretton-Woods - de abril a junho de 1944 -, onde a ideia de "hierarquia de moedas" entre devedores e credores seria uma maneira de “(...) sublinhar a capacidade inferior das economias devedoras e "dependentes" de atrair recursos livres para a aquisição de ativos e bens denominados na moeda nacional" 195 .

Sendo assim, essa decisão de Zampari de implantar a cotação do dólar como base dos valores a pagar seria para eventualmente eliminar efeitos inflacionários da moeda nacional em sua administração e obter vantagens lucrativas em moeda nacional nas transações e pagamentos efetuados, algo visto desde aquela época como “(...) totalmente contra-indicado, podendo provocar uma sub ou superestimação dos valores, apenas pelo fato de não representar seu real valor (de compra) na data em que se esteja considerando fazer pagamentos" ${ }^{\text {196 }}$, seja de insumos ou mesmo dos muitos empréstimos tomados junto aos bancos estatais. Possivelmente, Zampari tenha feito isso desde o início de operação de suas empresas também como uma maneira de prevenir a possibilidade de que qualquer eventual movimento de instabilidade política tivesse sobre ele o mesmo efeito nefasto.

Em meio a esse contexto, ainda que sofrendo seus efeitos de forma colateral, Abilio Pereira de Almeida estava por assumir por um acordo com o BANESPA a utilização dos equipamentos embargados da Vera Cruz para fundação de sua própria produtora, a Brasil Filmes - tendo como sócios colegas do TBC e da Vera Cruz, como Joe Kantor, Lima Barreto, e outros. Em meio a isso, ele apresentou à direção do TBC um texto onde prometia, segundo nota no Diário da Noite de 6 de janeiro de 1955, “(...) mexer em caixas de marimbondos, causando reação dos paulistas quatrocentões que negociaram a Revolução de 1932 para se aliarem ao Estado Novo que tanto criticavam". A peça era louvada durante seus ensaios como a melhor escrita pelo autor, o que junto com suas declarações algo polêmicas ajudaram a criar expectativa maior para a estreia.

\footnotetext{
195 BELLUZO, Luiz Gonzaga de M.; ALMEIDA, Júlio Cesar de G. de. A economia brasileira: da crise da dívida aos impasses do real. Rio de Janeiro: Civilização Brasileira,2002, apud PRATES; CINTRA, 2007, p. 7 ${ }^{196}$ CARDOSO, 1971, p. 11
} 


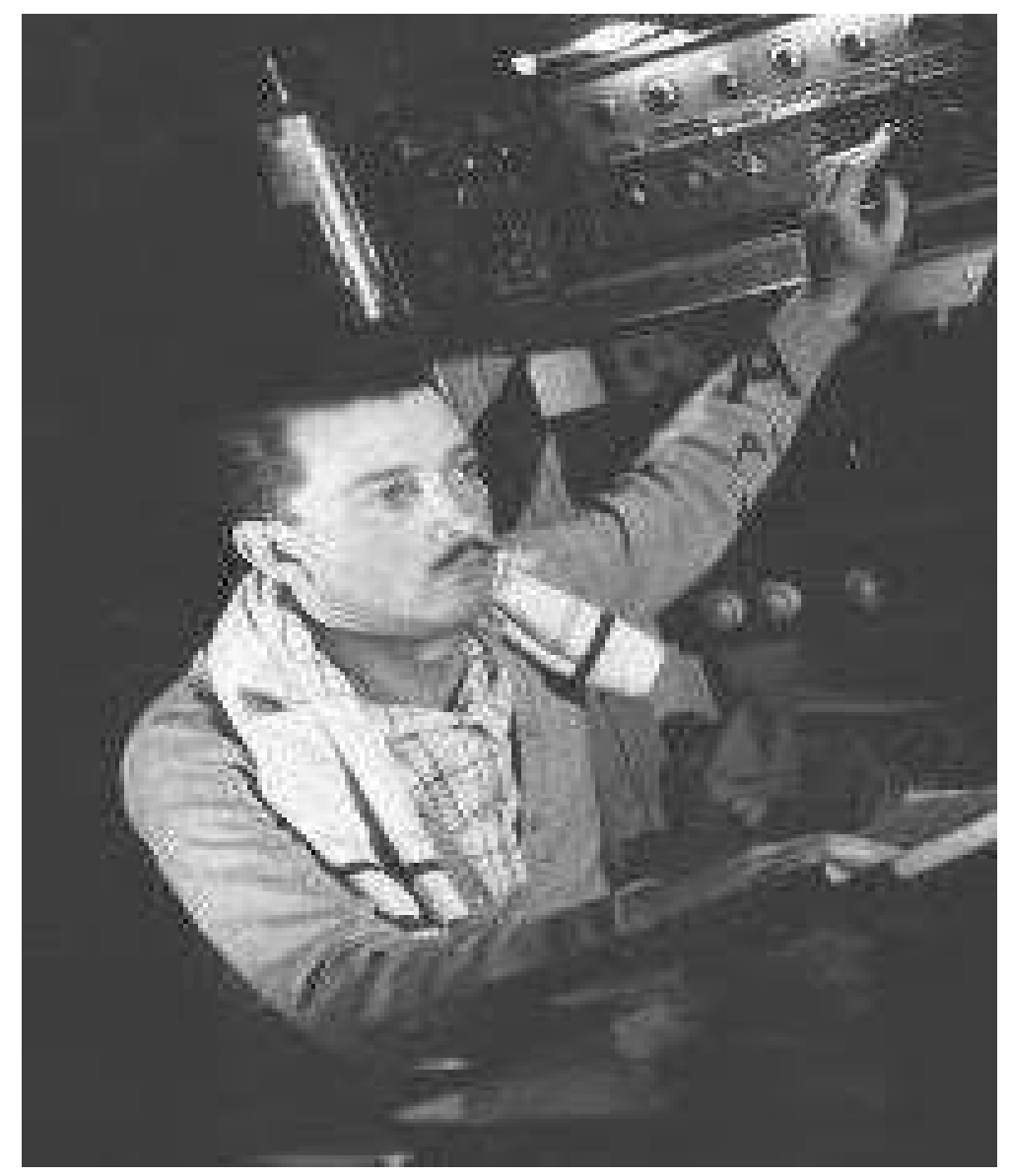

Imagem 16 - Abílio Pereira de Almeida

Após finalmente estrear em março de 1955, "Santa Marta Fabril S A" realiza o seu intento de, “(...) ao girar em torno da indústria, desvendando as bases em que se assenta os acordos que a dão energia indutora do progressso (leia-se dinheiro)" ${ }^{\text {"197 }}$, criar uma acalorada discussão entre seus frequentadores habituais do teatro da Bela Vista, com “(...) espectadores que se retiraram da sala antes do término do espetáculo"198 . O público eventual também assistia à peça curioso com a abordagem sobre a elite tradicional. Mesmo a crítica se sentiu ressentida, a ponto de causar uma inédita reação de silêncio à montagem no jornal $O$ Estado de $S$. Paulo, que historicamente mais defendeu a abordagem artística do TBC. Tal pedido para se esquecer a peça de Almeida teria vindo da prórpia família dona do jornal - os irmãos de Julio de Mesquita Filho, presidente do jornal, a teriam assistido na estreia e contado a ele suas impressões.

${ }^{197}$ GUZIK, 1986, p. 114

${ }^{198}$ CAMPOS, 2009, p. 33 
Apesar dessa campanha de parte da imprensa, a montagem de "Santa Marta Fabril S.A" ganha um apoio inesperado na figura de Miroel Silveira, que no jornal Folha da Manhã de 8 de março de 1955 escreve crítica onde fala de muitos aspectos que considerava parte de um processo de evolução tanto de Abílio como do TBC em relação à sociedade à sua volta, ainda que destacando influências estrangeiras sobre a peça de forma bastante irônica, como se sua fala tivesse expressado algo parecido a respeito da peça, e não sobre algo anterior a ela:

Louve-se o TBC inicialmente pelo fato de encenar um autor brasileiro. Nada mais importante para a consolidação de nosso teatro de que a apresentação de novos textos nacionais, sejam eles maus, regulares ou bons, pois é desse contato com o público que surgem e se firmam os autores autênticos. [...] Em "Santa Marta Fabril S.A." Abilio Pereira de Almeida já demonstra progressos de ordem filosófica, pois faz desta vez uma como que apologia da doutrina do SESI - pacificação social, o patrão resolvendo problema dos operários pelo simples fato de recebê-los em comissão e permitir-lhes a existência [...] Contudo, tão interessante é o tema, que mal foi a peça representada no Brasil já encontrou extraordinária repercussão no estrangeiro: dois obscuros autores, um inglês e outro francês, Somerset Maughan e André Maurois(ambos dramaturgos modernos, da primeira metade do séxulo $X X)$, impressionados com o estalo do autor patrício, resolveram escrever e publicar "The Circle" e "Le Cercle de Famille". [...] Para quem encara a peça de um ponto de vista socialista, é animador verificar que os próprios elementos da aristocracia, como o autor, timbram em revelar de público as mazelas de uma classe decadente fazendo um auto de fé espetacular. Para os amigos e membros do clã social a que pertence o autor, deverá ser incômodo verificar que abrigaram em seu seio a própria onça, pois de tantas figuras que passam pela peça, vividas num ambiente de Paulistas de 400 anos, ele não salvou nenhuma que fosse decente ou digna. ${ }^{199}$

Artisticamente, a peça consegue também levantar a carreira não apenas de Abílio, mas de atrizes que desempenhavam funções consideradas menores até então: além de ter Cleyde Yáconis como protagonista, se destacaram Dina Lisboa, atriz tradicional da revista paulistana chamada ocasionalmente para compor elenco no TBC entre 1953 e 1957 ainda que sem nunca ter fechado contrato com a companhia (também trabalhou na companhia Nydia Lícia-Sergio Cardoso), e Célia Biar, sempre considerada

\footnotetext{
${ }^{199}$ SILVEIRA, 1976b, p. 145-6
} 
coadjuvante e vista até mesmo como "secretária" 200 dentro da estrutura do teatro, mas que com sua graça e presença em cena ajudou a levantar o interessse na peça. Considera-se com isso que "Santa Marta..." tenha sido a única peça nacional do TBC a ter finalizado com saldo financeiro positivo, ou seja, sem ter gasto em sua produção mais do que foi arrecadado.

Nesse caso, os números da bilheteria foram realmente espantosos não apenas para o padrão dos autores nacionais retratados no teatro, mas para os da própria companhia, com quarenta e duas mil pessoas em cento e cinquenta apresentações - $80 \%$ de ocupação média em quinze semanas em cartaz. Os anúncios de chamada ao público eram constantes, fomentando ainda mais a curiosidade, principalmente pelo fato de que em muitos deles via-se apenas o anúncio, sem uma crítica que o acompanhasse. Também financeiramente, pode-se dizer que o prejuízo ocasionalmente causado na exibição de peças brasileiras até aquele momento foi enfim compensado pelo sucesso algo ocasional e até certo ponto inesperado da peça de Almeida.

Em todos os termos, a montagem estava sendo um sucesso e explicitou a política da casa evidenciada naquele momento em que se tentava aliar um teatro popular a um sentimento de contribuição à vida cultural na cidade e na sociedade brasileira através da reflexão sobre suas atitudes. Porém, ela acabou sendo também um marco de acontecimentos não muito felizes na história do $\mathrm{TBC}$, não só por paradoxalmente escancarar que nem tudo era sucesso na empreitada de Zampari e Ciccillo Matarazzo, mas graças aos acontecimentos que viriam logo a seguir.

\subsection{Queda do TBC e os Auxílios e Intervenções Estatais}

Até o momento em que "Santa Marta Fabril S.A," estreou em 1954, o TBC já havia passado por várias transformações, apesar de manter seu modo de operação de maneira próxima a como foi planejado por Zampari e Ciccillo Matarazzo no seu início. Pensando na classificação que Guzik (1986) deu a essas diferentes fases da companhia, podemos pensá-las na perspectiva da produção e execução das peças no TBC de forma diferente a como isso foi compreendido e assimiliado pelos artistas, jornalistas e críticos, e pelo público que freqüentou esses primeiros anos do teatro. Desse modo, o

\footnotetext{
${ }^{200}$ Nydia Lícia é quem a cita dessa forma na ocasião da entrega da intimação pela polícia após o episódio da Pagodeira Existencialista em 1950, in: LíCIA, 2007, p.16. Cf. na p. 106
} 
que para ele se definia como "dinamismo" na fase da ocupação do teatro pelos grupos amadores a partir da inauguração em 1948, pode ser visto como uma maneira de se destacar de outro modo a competição interna criada naquele ambiente, para saber quem estaria preparado a ingressar na companhia profissional sacramentada dois anos depois.

Junto a isso, a estratégia de expansão do TBC para outros centros do país começava a ganhar fôlego desde que as idas ao Teatro Ginástico do Rio passaram a se tornar constantes a partir de 1954, a ponto de fazer do teatro carioca uma espécie de "filial" do TBC, em um movimento que se prometia perdurar por bastante tempo, contribuindo enormemente para a difusão do modelo de teatro do TBC moldado a partir deste e de outros sucessos teatrais dentro da empresa teatral de Zampari. Essa expansão era causada por dois movimentos distintos a partir do TBC: um deles era a expansão da própria marca, outra a saída cada vez maior de pessoas importantes para o bom funcionamento da casa.

Considerando que a Vera Cruz era parte do passado, esse plano de expansão era um bom meio de manter os integrantes ativos da companhia ocupados em trabalhos junto aos colegas, ganhando confiança no comprometimento deles com o futuro desse teatro. Contudo, as primeiras experiências de saída para o Rio de Janeiro não conseguiram dirimir por completo as saídas ocorridas nos últimos tempos, mesmo porque uma das forças do TBC era a busca pelo entrosamento do elenco e da homogeneidade de atuações, diminuindo ao máximo a distância entre primeiros atores e o restante do elenco em um trabalho de continuidade com os diretores estrangeiros.

Pois, se para Guzik a plena profissionalizalçao desse teatro a partir de 1950 pode ser representada como a fase do "sucesso" da companhia, e a chegada de nomes como Ziembinski e Tônia Carrero, além do retorno de Paulo Autran, a partir de 1953 se configuraria na fase das "estrelas", deve-se pensar também no quanto as saídas de nomes como Jacobbi e Sergio Cardoso, e a consolidação de outras figuras como Cacilda Becker, poderiam confirmar ou fazer duvidar desse tipo de classificação. Afinal, tais fases poderiam perfeitamente estar entremeadas entre si, também junto a uma constante gestão de crises, como o caso da derrocada da Vera Cruz deixou explícito. 
Cabe ressaltar que não foram apenas atores/atrizes e diretores do corpo principal do TBC que deixaram a companhia nesses primeiros tempos: levantamento feito até o final de 1953 mostrava a saída dentre os primeiros integrantes da companhia estável de intérpretes do porte de Sergio Cardoso, Nydia Lícia, Antonio C. Carvalho, Elisabeth Henreid, Ruy Affonso e Carlos Vergueiro. Destas, a saída de Ruy Affonso foi a mais controversa, pois este deixou o TBC após um pequeno desacerto quanto a propostas de salário que causou uma rescisão de contrato unilateral por parte da SBC. Além deles, outros que passaram pelo teatro desde sua profissionalização e tiveram certo destaque também haviam deixado a casa, como Raquel Moacir, que havia iniciado bem seu trabalho em "A Ronda dos Malandros", Maria Lucia, e Maria Della Costa. Dentre todos esses, muitos conseguiram se arranjar em grupos então existentes ou próprios, configurando companhias tão fortes e estáveis quanto o TBC em sua estrutura e até com atuação mais livre. Elisabeth Henreid, por exemplo, após o trabalho no TBC e Vera Cruz, assinou contrato com a companhia de Nicete Bruno, voltada à comédia.

Ainda em 1954, Nydia Lícia e Sergio Cardoso, tendo visto o fim da CDN com a qual tanto contribuíram, formaram companhia própria com Leonardo Vilar e Eva Wilma que se estabeleceu no Teatro Espéria (depois Teatro Bela Vista) gastando quatro milhões de cruzeiros em reformas para encenar principalmente autores nacionais que não chegavam ao TBC, a começar pela estreia com "Lampião", de Rachel de Queiroz $^{201}$. Maria Della Costa, que chegou a ser primeira atriz em 1951 na montagem de "Ralé", de Górki, abriu seu próprio teatro também em 1954 em São Paulo, em sociedade com o empresário Sandro Polloni, então seu marido - na época, foi considerado um dos melhores teatros particulares de São Paulo, inclusive com a mesma capacidade de público que o TBC.

Porém, mais dramático que aparar arestas pelas faíscas dos atritos pessoais e profissionais dentro do teatro, foi ter de lidar com traumas concretos. E o TBC sofreu um baque com um incêndio ocorrido durante a temporada de "Santa Marta..." em 6 de junho de 1955, onde foram destruídas parte das instalações do teatro. A parte que alegadamente sofreu maiores danos foi a dos depósitos dos cenários, onde estavam os móveis e gravuras preparados para a peça seguinte no programa do TBC - "Volpone", do inglês Ben Jonson.

${ }^{201}$ A peça foi feita no Teatro Leopoldo Fróes, pois a reforma no teatro próprio só se concluiu em 1956. 


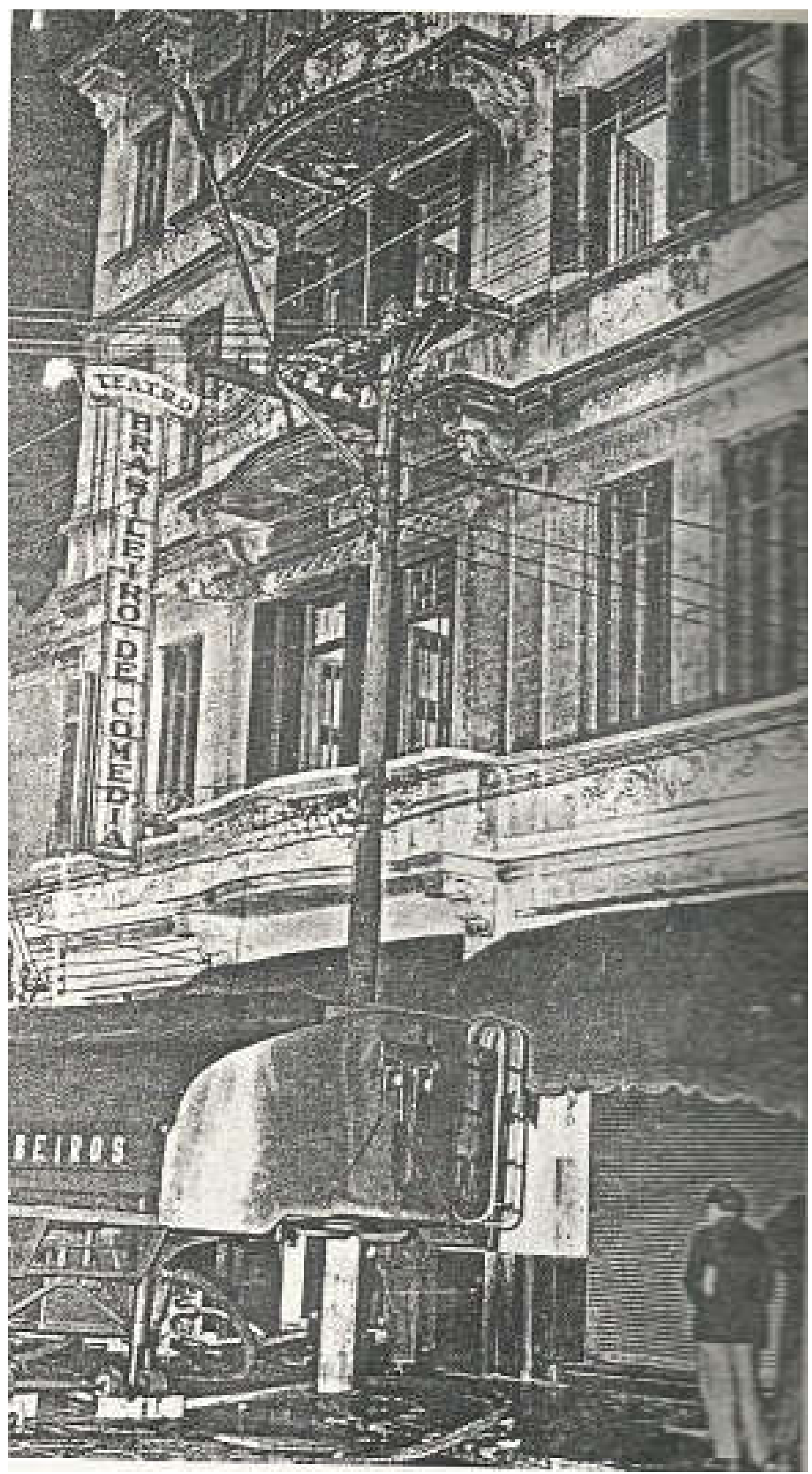

Imagem 17 - Incêndio na sede do TBC em São Paulo em 1954 (ARRUDA, 2001) 
Os relatos sobre o incêndio levaram um pouco mais de tempo que o esperado para que fossem tomadas de forma objetiva as devidas proporções dos danos e prejuízos, conforme pode-se avaliar melhor o que efetivamente se deu quanto à estrutura do prédio. O jornal $O$ Globo destacava no dia posterior ao incidente, em 7 de junho, o fato de que "(...) palco e plateia haviam sido salvos pelos bombeiros, com o incêndio atingindo outras salas do prédio e ocasionando prejuízos”. O Correio da Manhã, também do Rio de Janeiro, relatava no dia 8 de junho que “(...) a primeira informação, rude e seca, pela madrugada (era que) o fogo havia consumido por inteiro o prédio (para logo dizer que) os rostos fechados de antes parcialmente desanuviavam pela gravidade menor que o esperado para o ocorrido". O Estado de Sâo Paulo, então já no dia 9 de junho, lamentava que “(...) o fogo pudesse consumir dessa maneira estúpida um bem que de alguma forma já era coletivo."

Em se tratando da objetividade esperada para a avaliação desse tipo de acontecimento, percebe-se pelo inúmeros relatos dos jornais uma maior atenção aos detalhes do ocorrido nos jornais cariocas, enquanto nos periódicos de São Paulo a impressão era de que se precisava dar notícias ligeiras quanto à volta de atividade do teatro. Com as notícias ainda desencontradas nos jornais da cidade de São Paulo causando mais desinformação do que alívio quanto à situação geral do teatro, a própria SBC pagou um anúncio de jornal, reproduzido no dia 9 de junho tanto nos jornais de São Paulo como nos do Rio de Janeiro, em que dizia:

A Sociedade Brasileira de Comédia, sensibilizada ante as demonstrações de solidariedade recebidas do público $e$ autoridades em geral por ocasião do sinistro verificado no último dia 6, apresenta os mais sinceros agradecimentos $e$ comunica que o prédio já se acha desimpedido e considerado fora de perigo pelas autoridades competentes. Hoje, quintafeira, "Santa Marta Fabril S.A.", de Abilio Pereira de Almeida excepcionalmente vesperal às 16 horas e sarau às 21 horas.

Quanto aos detalhes do ocorrido, o relato a seguir publicado pelo jornal Correio da Manhã em 8 de junho, a partir de entrevista dada por um dos seguranças do edifício junto às primeiras avaliações a respeito do ocorrido, pode certamente ajudar a compor de forma melhor apurada uma imagem do que de fato aconteceu ao TBC no dia 6 de junho de 1954: 
Sendo segunda-feira tradicionamente o dia de descanso no mundo teatral, foi palco da Rua Major Diogo cedido a um grupo de amadores ingleses que ensaiavam um espetáculo prestes a ser apresentado às colônias britânica e americana de São Paulo ${ }^{202}$. Em meio ao ensaio, grossos rolos de fumo invadiram todas as dependências do prédio, sendo imediatamente chamados os bombeiros, os quais como já é de hábito em nosso país, tiveram que se haver primeiramente com a falta da água. Após horas de luta, já destruída a carpintaria e ameaçados os depósitos, foram finalmente as chamas dominadas, salvando-se o palco e o auditório do teatro. Como sofreram apenas a ação da água, calcula-se que não haverá interrupção na programação artística.

Quando na nota da SBC se fala em autoridades presentes, é porque, na manhã seguinte ao incêndio, o teatro recebeu a visita do então prefeito de São Paulo, William Salem. Eram tempos complicados politicamente, onde velhas alianças que sustentavam a democracia pareciam estar se partindo, da mesma forma como ocorrera no plano federal com a pressão política que incorreu no suicídio de Getúlio Vargas em 24 de agosto de 1954. No caso de São Paulo, essas alianças se partiam com acusações mútuas entre Adhemar de Barros e Jânio Quadros que perpassavam todas as instâncias de governo, trazendo embates entre os que buscavam manutenção no poder de velhos quadros e novas composições dentro da mesma estrutura.

No âmbito da cidade, William Salem estava em 1955 cumprindo mandato como interino após a renúncia de Jânio Quadros, que havia abandonado seu posto com menos de dois anos no cargo para galgar novas posições políticas ${ }^{203}$, forçando com suas ações a posse do presidente da Câmara Municipal na prefeitura e o chamamento de novas eleições em seis meses. Elas haviam acabado de ocorrer em 22 de maio de 1954, dando vitória a um novo prefeito, Juvenal Lino de Matos, que assumiu no dia $1^{\circ}$ de julho, pouco menos de um mês após o incidente no TBC. E tanto ele como o prefeito seguinte, Vladimir Piza, ficaram por apenas um ano no cargo $^{204}$. Visto a situação política complicada na cidade naquele momento, as promessas feitas por Salem logo após o

\footnotetext{
202 O Amateur's Society, grupo de Robert H. Eagling nos anos 1940, era dos que mais utilizavam a estrutura do teatro para suas atividades próprias.

203 Porfírio da Paz, então vice-prefeito, substituia o titular Jânio Quadros para que pudessem se candidatarpara o Governo do Estado nas eleições de 1954 - na época, os votos para titular e vice do Executivo eram dados em separado na mesma eleição. Jânio e Porfírio foram eleitos contra Adhemar de Barros e Janio reassumiu o cargo de prefeito até 31 de janeiro de 1955, quando titular e vice renunciaram conjuntamente para assumir os cargos de governador e vice-governador de São Paulo.

204 Juvenal Lino de Matos assumiu vaga no Senado em abril de 1956 e Vladimir, seu vice, ficou no cargo de prefeito até abril de 1957.
} 
incêndio de ajudar a cobrir os prejuízos de mais de um milhão de cruzeiros no teatro acabaram não sendo levadas adiante, por William Salem ter deixado seu cargo poucos dias depois, restando à SBC arcar sozinha com sua reconstrução.

$\mathrm{O}$ acontecimento com o TBC sequer foi único naqueles tempos, tanto em relação ao incêndio quanto às dificuldades de acesso a qualquer meio de financiamento em nível municipal pela falta de políticas do Executivo e entraves criados pelo Legislativo. No Rio de Janeiro, em 1950 houve um grande incêndio no Teatro Carlos Gomes, que à época abrigava a companhia de Bibi Ferreira, e um caloroso debate posterior na Câmara impediu que se concedesse quatrocentos mil cruzeiros de ajuda para a companhia por ser considerado investimento em companhia privada, restando a esta alugar o Teatro São José. Com o Teatro Copacabana ocorreu o mesmo inicidente em 1953, e a reconstrução do teatroapós o incêndio foi tocada totalmente pela família Guinle.

Assim, com a temporada de "Santa Marta..." seguindo até o fim, e "Volpone" com direção de Ziembinski tendo sua estreia adiada por vinte a trinta dias, a rotina no TBC aparentemente havia retornado ao normal. Com isso, a diretoria da SBC se concentrou na estratégia de estreia no Rio para "Santa Marta..." no Ginástico ainda em 1955, mandando Adolfo Celi ao Rio com elenco levemente modificado em relação à montagem paulista: Tônia Carrero substituiu Cleyde Yáconis - possivelmente como chamariz de público - e Fredi Kleeman alegou problemas de saúde para não viajar, suscitando boatos de que se sentiria "perseguido" por causa de sua personagem na peça.

Como a peça em carreira na cidade ("Profundo Mar Azul", de Terence Rattingan) arrecadava cento e sessenta mil cruzeiros por fim de semana com Paulo Autran e Tônia Carrero, a direção decidiu encampar "Santa Marta..." na cidade com bombásticos e recorrentes anúncios pagos que falavam da "peça que abalou São Paulo", destacando principalmente a censura a menores de 18 anos e "a sátira amarga à sociedade paulista" presentes na peça. A crítica carioca contribuiu para o clima de expectativa para a peça, que contou com o apoio de veículos como o jornal A Noite, onde Ney Machado publicou em 19 de julho de 1955 que “(...) a maior qualidade de Abílio é a veracidade em fotografar ambientes e cinzelar personagens", ainda que tais características tenham sido contrapostas em jornal paulista. 
Numa crítica publicada justamente em $O$ Estado de S. Paulo em 20 de julho de 1955 - quebrando assim a barreira autoimposta que o jornal mantinha para com a peça de Abílio Pereira de Almeida - e replicada em vários jornais do Rio de Janeiro dado que o crítico alega ter visto a montagem nessa cidade, Rubem Braga desabonava a peça, chamando-a de "chanchada", ao dizer que sua construção era "menos que ruim", com uma construção de personagens “(...) marcada de maneira primária, grosseira, infantil” (apud CAMPOS, 2009, p. 33).

O destaque à classificação etária nos anúncios era também para não entrar em maiores conflitos com outras autoridades, no caso eclesiais, pois na semana de estreia da peça no Rio de Janeiro em julho de 1955 estava sendo realizado na cidade um Congresso Eucarístico - encontro mundial católico como a Jornada Mundial da Juventude, porém de caráter mais solene -, e apesar de toda polêmica criada, o TBC achou importante colocar-se à disposição dos visitantes, oferecendo inclusive descontos nas matinês para não melindrar o apoio da comunidade católica, que considerava importante para a carreira do teatro na cidade - mesmo porque todos os teatros do Rio estavam com campanhas especiais para a ocasião. E os números da estreia foram ótimos, com cento e vinte e cinco mil cruzeiros de bilheteria no primeiro final de semana - um milhão e dez mil cruzeiros no primeiro mês na cidade.

Dessa renda, e da bilheteria anteriormente reunida em São Paulo, é importante destacar uma resolução da SBAT que regulamentava o repasse de $10 \%$ da renda da bilheteria de peça brasileira ao autor como pagamento de direitos autorais, algo normalmente pago também para produções estrangeiras com possibilidade de negociação direta da produção local com seus representantes. Nota de 3 de agosto de 1955 do jornal A Noite, ao comentar os royalties ganhos por Abílio Pereira de Almeida pelo fim de semana de estreia de "Santa Marta..." no Rio - doze mil e quinhentos cruzeiros - colocava a profissão de dramaturgo como "o trabalho intelectual mais bem pago do Brasil". À parte o fato de que esta era a única peça nacional rentável do TBC, na mesma página o jornal havia colocado uma problemática em relação à "inflação" nos salários do teatro, usando como exemplos, entre outros, dois artistas do TBC - Adolfo Celi, que recebia sessenta mil cruzeiros ao mês na direção, e Tônia Carrero, que ganhava trinta mil cruzeiros ao mês. 
Apesar de o jornal destacar esses salários como resultado do trabalho dos artistas e da almejada estabilidade das companhias, o TBC seguia com seus próprios ruídos decorrentes da falta de negociação quanto a estes ganhos. No final da temporada de "Santa Marta..." em julho de 1955, aconteceu aquilo que segundo Cacilda Becker foi “(...) a maior das desilusões artísticas de Franco Zampari”"205, com Adolfo Celi anunciando sua demissão já com a intenção de formar nova companhia com Tônia Carrero. Essa desilusão se deu não apenas pela saída dos atores, mas principalmente por Zampari considerar não poder a partir de então contar com Celi como seu sucessor na condução do TBC, algo que seria inviável com seus afazeres com a nova companhia, que ambicionava “(...) se distinguir como um dos principais conjuntos do país seguindo diretrizes semelhantes às do TBC.,206

O acordo estabelecido era de fazer mais uma peça até o final do ano - que seria "Liolá", de Pirandello, a ser apresentada primeiro no Ginástico para que em 1956 formasse a nova companhia com Tônia Carrero, já que ela estaria de qualquer maneira de contrato terminado com o TBC. Cabe destacar, porém, o fato da interrupção da montagem de "Liolá", que tem a ver com questões de intervenções estatais as quais o teatro sempre buscou evitar. Após um mês e meio de ensaios decorridos, a peça não chegou a ser encenada por uma interferência do Juizado de Menores do Rio, através de Eudoro de Magalhães, quanto à presença de três crianças nos figurantes da apresentação. Cid Leite da Silva, administrador da filial carioca do TBC, relata minuciosamente essa questão em notícia do jornal $A$ Noite de $1^{\circ}$ de setembro de 1955 , falando das etapas da montagem e do papel do agente judiciário perante a peça:

Uma semana depois (do primeiro contato com o juiz de menores), o Doutor Eudoro garantiu-me que já tinha lido a peça e que não via inconveniente na apresentação das crianças. Diante disso, fui à Sociedade de Autores (SBAT), paguei o valor de vinte mil cruzeiros e assinei o contrato para montagem da peça. [...] Fizemos despesas com montagem, contratação de elementos etc. [...] Quando voltamos a falar com o curador de menores, a nossa peça estava impugnada. [...] Apelamos para o juiz, provando que as cenas com as crianças não continham impropriedades, nada conseguimos. Tivemos que suspender os ensaios. Se tivermos que pagar indenizações à SBAT, podemos avaliar (os prejuízos) em 300 mil cruzeiros.

\footnotetext{
205 MAGALDI; VARGAS, 2001, p. 219
}

${ }^{206}$ Dionysos, 1980, p. 49 
Sobre isso, Mario da Silva, tradutor do texto, escreveu um artigo no Correio da Manhã de 22 de setembro de 1955 bradando contra “(...) os prejuízos ao TBC e da equipe envolvida em honesto trabalho" e a postura da Censura Teatral, órgão federal ligado ao Departamento Federal de Segurança Pública (DFSP) que fazia a classificação etária das peças. O órgão, continuidade do DIP e seguidor das mesmas diretrizes, era acusado de classificar quaisquer peças de teatro como passível de serem assistidas apenas por pessoas acima de 18 anos independente da temática, pois este colocava qualquer manifestação teatral no mesmo patamar qaunto à possibilidade de se tornarem passíveis de veto. ${ }^{207} \mathrm{O}$ artigo de Mario da Silva cita peças do TBC que utilizaram crianças, como as "Antígonas", e outras que estavam nos planos do TBC e que, segundo ele, poderiam ser alvo de intervenção da censura mesmo em São Paulo ${ }^{208}$, como "Casa de Bonecas", de Ibsen, que acaba realmente não sendo encenada pela companhia.

Um dos motivos alegados por Celi para formar sua nova companhia, que também contava com Paulo Autran a convite de Tônia Carrero, consistia em levar a cabo um dos projetos que ainda não haviam sido realizados pelo TBC, o de levar o teatro feito pela companhia de forma regular para outros lugares além do Rio e de São Paulo. Isso era uma tarefa um tanto dispendiosa - não havia mais que um vôo por dia para outras cidades além de Rio e São Paulo; o transporte ferroviário começava a ser deixado de lado pelos gestores públicos; e o transporte rodoviário ainda era precário e insuficiente -, portanto somente com muita força de vontade se empreendia tal aventura.

Adolfo Celi considerava isso possível através de um "(...) organismo novo ágil e correto (com) ideais de elevação do padrão do espetáculo teatral (para) de uma criação que não poderia senão colaborar para melhoria do espetáculo nacional, uma vez que se conservem o nível de repertório e uma apurada forma cênico-interpretativa" ${ }^{\text {"209 }}$. Tais ideais não estavam desintonizados aos do TBC, porém Celi considerava àquela altura

\footnotetext{
${ }^{207}$ Após o Estado Novo, a censura foi reclassificada segundo Decreto de Lei n. 20.493 , justificando no artigo 41 a proibição de obras culturais com base, entre outras coisas, na “(...) ofensa ao decoro público, às religiões, ou fossem contra o regime vigente e os interesses nacionais", com a autoridade para tanto sendo dada ao chefe da Seção de Diversões Públicas, responsável pela fiscalização. In: GARCIA, 2009, p. 13-4

${ }^{208}$ O Rio de Janeiro - ainda Distrito Federal até 1960 - e o Estado de São Paulo foram por anos os únicos com órgãos de censura teatral. Segundo o diretor do DCDP (Divisão de Censura de Diversões Públicas) do Rio de Janeiro, (...) "por outras áreas da federação não terem pessoal suficiente para executar o serviço" (GOUVEIA, 1975, apud GARCIA, 2009, p.44), dada a sua centralização e burocratização no âmbito federal, e por esses locais terem legislação própria que não seguia a censura federal em alguns pontos. Cf. nas p. 159; 189

${ }^{209}$ BARROS DE ALMEIDA, 1987a, p. 31
} 
que a companhia de Zampari estaria aquém de atender essa necessidade do teatro brasileiro, por sua pesada estrutura não valorizar da mesma forma que em seu início a formação de atores de maneira contínua para renovação de seus quadros, preferindo trabalhar desde algum tempo com artistas prontos e experimentados.

Quando Celi se referia à questão de que o TBC não investiria o suficiente na formação de atores, ele lembrava de uma iniciativa que ele mesmo havia promovido em conjunto com o jornal Correio da Manhã no Rio de Janeiro, publicada por este jornal no dia 9 de setembro de 1954, que colocou jovens do Conservatório Nacional de Teatro ${ }^{210}$ gerido pelo SNT e do Teatro do Estudante, de Paschoal Carlos Magno, para assistirem a uma sessão de "Assim É...Se Lhe Parece” na terça seguinte, dia 14. O jornal destaca que os estudantes de tais escolas de teatro muito dificilmente estavam entre os que recebiam convites na estreia dos espetáculos na cidade, prática que dificilmente se repetia em São Paulo pela proximidade da EAD com o TBC desde seu início, parecendo muito mais uma maneira do TBC manter certa distância na relação com equipamentos públicos.

Apesar de ainda estar se refazendo financeiramente mesmo com o sucesso de "Santa Marta..." em São Paulo e no Rio, o TBC respondeu à crise mostrando que seu projeto de expansão da marca e do seu modelo de teatro não estava totalmente descartado. Em 15 de agosto de 1955, foi lançada a formação de um terceiro quadro de artistas, distinto dos que ficam fixos nas suas sedes em São Paulo e no Rio ou que passam por ambos. O elenco flutuante de doze a dezoito artistas estava sob direção de Eugenio Kusnet, russo tido como introdutor do método de Stanislávski no Brasil e que trabalhava com teatro no país desde participação em "Paiol Velho", de Abílio Pereira de Almeida, encenada no TBC em 1951, ajudando também a formar o Teatro de Arena, fundado em 1953 e considerado então um centro de experimentação da linguagem teatral em São Paulo em processo de consolidação de suas ideias.

Sob o nome piloto de Laboratório de Teatro Volante, havia uma intenção por parte de Kusnet de fazer testes e recrutar jovens promissores das cidades visitadas, e também lançar publicidade da companhia para possíveis turnês dos elencos principais. A única pessoa desse grupo que conseguiu chegar ao elenco principal logo após a formação desse grupo foi Silvia Ortoff, então uma atriz com formação no exterior -

${ }^{210}$ Continuação do projeto estatal do Curso Prático de Teatro, que mudou de nome em 1953. 
vinda de uma escola de artes em Paris - que consegue dois papéis no TBC de São Paulo no final de 1955, em "Mary Stuart", de Schiller, e "Os Filhos de Eduardo", de Sauvajon. Mesmo com sua formação através desse terceiro elenco, Silvia termina por buscar outra expressão artística após participação nessas peças, enquanto outros selecionados acabam por vir ocasionalmente atuar em São Paulo (caso de Sonia Gabi, oriunda da Escola de Teatro da Bahia que tambem vem ao TBC) ou para compor elenco de companhias que já excursionavam pelo país, como as companhias de Maria Della Costa e Tônia-CeliAutran, enquanto prosseguiam ensaios do novo elenco no Ginástico.

Com a saída de Celi, Zampari tinha em mente um plano a ser implementado de forma mais imediata. Desde o anúncio da saída dele do TBC, Zampari entrou em contato com Maurice Vaneau, então diretor do Teatro Nacional da Bélgica. Tudo começou após uma turnê da companhia estatal belga pelo país em junho de 1955 para apresentar uma série de várias peças. Zampari ficou impressionado especialmente com "Barrabás", de Ghelderode, onde Vaneau era o diretor - em algumas das peças da turmê, ele atuava no palco -, e assim lhe fez para permanecer no país para ser diretor artístico da companhia de Zampari em São Paulo e no Rio. De alguma forma, Zampari viu praticamente desde o primeiro momento em Vaneau aquele que poderia ser o perfeito substituto de Adolfo Celi na condução dos projetos do TBC, de maneira disciplinada e criativa.

Para fechar o ano de 1955, Zampari apresentou um balanço ${ }^{211}$ em que contrapunha gastos da companhia com as perspectivas de planejamento a curto prazo. $\mathrm{O}$ primeiro dado destacado por ele foi em relação ao novo teto de salários. Com a saída de uma só vez daqueles que detinham naquele momento os maiores vencimentos da casa, Zampari estabeleceu critério mais claro quanto ao nivelamento dos ganhos entre os remanescentes. Os artistas da categoria "A", tendo mais tempo de casa e contrato de exclusividade por ao menos um ano, recebiam vinte e tres mil cruzeiros. Esse nivelamento chegaria até a categoria dos recém-contratados, que receberia oito mil cruzeiros, com um abono de 50\% ao salário àqueles que também atuassem no Rio de Janeiro, com a mesma peça que fazia em São Paulo ou em outra que entrasse em temporada na cidade.

${ }^{211}$ Revista do Teatro Brasileiro, n. 2, de dezembro de 1955, apud Dionysos, 1980, p. 103-4; 161-3 
Ainda que se considerasse esse gasto e o dos encenadores - entre vinte e cinco, e trinta mil cruzeiros, com abono de 30\% para quem fizesse jornada no Rio - os maiores da empresa individualmente, outras despesas correntes devem ser consideradas, como os gastos contínuos e elevados com a cenografia e a indumentária, ou a dos funcionários registrados dentro da estrutura celetista vigente no teatro. Tudo isso dentro deum limitado arco de receitas na companhia, advindas em grande parte da bilheteria e em menor parte de eventos culturais diversos realizados no espaço do teatro. Abaixo, podese vislumbrar um pouco a proporção que cada atividade descrita contribui no orçamento do teatro, dentro daqueles valores divulgados no decorrer da história:

\begin{tabular}{|c|c|c|}
\hline \multicolumn{3}{|c|}{ RECEITAS E DESPESAS ANUAIS DO TBC - 1955} \\
\hline \multicolumn{2}{|c|}{ Fontes de despesa } & Fontes de receita \\
\hline \multirow{4}{*}{$\begin{array}{l}\text { Salários de } 4 \\
\text { encenadores - Cr\$ } 1,3 \\
\text { milhões } \\
\text { Salários de } 15 \text { artistas - } \\
\text { Cr } \$ 2,5 \text { milhões } \\
\text { Administração da } \\
\text { SBC* } \\
\text { Aluguel dos teatros de } \\
\text { São Paulo e Rio * }\end{array}$} & $\begin{array}{l}>\text { Salário de funcionários* } \\
>\text { Pagamento a músicos* } \\
>\text { Direitos autorais* }\end{array}$ & \multirow{2}{*}{$\begin{array}{l}\text { Receitas de bilheteria } \\
\text { em São Paulo - TBC e } \\
\text { Rio - Ginástico - } \\
\text { Cr\$ 7,7 milhões** }\end{array}$} \\
\hline & $\begin{array}{l}\text { Iluminação - } \\
\text { Cr\$ } 1 \text { mil / lâmpada - } \\
200 \mathrm{~h} \text { de uso }\end{array}$ & \\
\hline & $\begin{array}{l}\text { Madeira de carpintaria - } \\
\mathrm{Cr} \$ 110 \mathrm{p} / \text { metro }\end{array}$ & $>$ Aluguel para ensaios * \\
\hline & $\begin{array}{l}\text { Tecidos para figurino - } \\
\mathrm{Cr} \$ 150 \mathrm{a} 200 \mathrm{p} / \text { metro }\end{array}$ & $\begin{array}{l}\text { Aluguel para recitais e } \\
\text { apresentações * }\end{array}$ \\
\hline
\end{tabular}

* sem estimativa; ** as peças em 1955 tiveram em média temporadas mais longas e de maior êxito Fonte: GUZIK (1986); revista Dionysos (1980); Acervo Gouvêa-Vaneau

Dentro dessas bases de receitas e despesas, Zampari ainda bradava o fato de não ter "nunca recebido subvenção do governo", ao mesmo tempo que dava sugestões de áreas onde poderia haver tal apoio ao seu teatro, como em viagens para promoção internacional do teatro brasileiro - Zampari destacou um convite do Festival Internacional de Viena para o TBC se apresentar lá em agosto de 1956, que para ele não podia ser aceito sem apoio oficial do Estado - e no incentivo para pessoas de menor renda irem ao teatro:

Para que maior número de pessoas possa assistir aos nossos espetáculos, a solução é que o governo adquira, algumas vezes, a lotação completa, e a revenda a preços menores, pagando a diferença. Não haverá rombo nos cofres públicos, as companhias teatrais teriam uma subvenção razoável $e$ as classes menos abastadas poderiam ver bom teatro. ${ }^{212}$

${ }^{212}$ Revista Dionysos, 1980, p. 163 
Não era razoável, mesmo nas limitadas opções de ajuda governamental da época em que a ajuda parlamentar ainda era o principal meio de obtenção de recursos e os únicos editais regulares de subsídio eram os editais dao SNT, que se desse subvenção a prédios alugados, e não de propriedade do ente que a administra, como admite Zampari ser a situação tanto do TBC quando do Ginástico naquele momento. Ainda assim, também se colocou uma ideia de envolvimento estatal no empreendimento que contemplaria tanto a necessidade de manutenção do prédio principal do TBC como teatro como a vontade da SBC de continuar administrando o imóvel:

Tanto o teatro da Rua Major Diogo como o Ginástico são alugados. Não tenho dinheiro para construir uma casa de espetáculos própria. Penso que o Governo Paulista, por intermédio de suas Caixas Econômicas e bancos, deveria oferecer ao TBC a possibilidade de comprar o edificio da Rua Major Diogo e construir um no Rio. Posso mostrar que o empréstimo necessário à compra do nosso teatrinho de São Paulo, resgatável em 20 anos com juros módicos na tabela Price, poderia ser amortizado mensalmente com quantia pouco superior ao aluguel. ${ }^{213}$

Curioso pensar tambem como Zampari ligava soluções concretas e imediatas para o teatro à movimentação da bilheteria. Visto que considerava que as políticas públicas não lhe alcançavam e que as possibilidades de receita do teatro estariam limitadas por sua capacidade física, por não haver escalonamento de preços entre o público - mesmo sócios não pagavam muito mais pelo preço das cadeiras individuais, apenas asseguravam lugar pela temporada -, qualquer plano de remodelação do teatro como o que se fazia naquele momento passava pela constante incerteza quanto a haver ou não aumento de bilheteria. Para Zampari, segundo o mesmo balanço, “(...) com todos os gastos que se tem, o preço do ingresso não devia ser de noventa cruzeiros, mas de cento e vinte" ${ }^{214}$. Ou seja, apesar do fato de que o TBC seguia sendo o teatro mais caro da cidade, sua política interna seguia insistindo em modelo que tenderia apenas a inchar a si própria, sem que houvesse perspectiva de solução.

\footnotetext{
${ }^{213}$ Revista Dionysos, 1980, p. 162

214 Idem Ibidem; o ingresso já havia, no momento dessa declaração, sofrido novo aumento de preço para a temporada de 1955, de oitenta para noventa cruzeiros, proporcional à inflação de $12,2 \%$ em um ano.
} 
Nesse contexto de reconstrução das bases do TBC, contando com menos pessoas dentre os integrantes históricos, Zampari contratou em 1955 os diretores Maurice Vaneau, da Bélgica, e Gianni Ratto, da Itália. Gianni era reconhecido por seu trabalho junto a Giorgio Strehler e Paolo Grassi na fundação do Piccolo Teatro e tambem no Teatro Scala di Milano, tendo vindo ao Brasil a convite de Sandro Polloni e Maria Della Costa para sua companhia própria em 1954. Seu estilo mais clássico e formal se contrapunha fortemente ao de Vaneau, que chegou ao TBC com fama de ter uma "conhecida habilidade para comédias leves",215 e por ter como parte de sua personalidade, segundo Sábato Magaldi, “(...) um talento inquieto e um cenógrafo de sensibilidade e delicadezas sempre elogiáveis" ${ }^{\text {216. }}$.

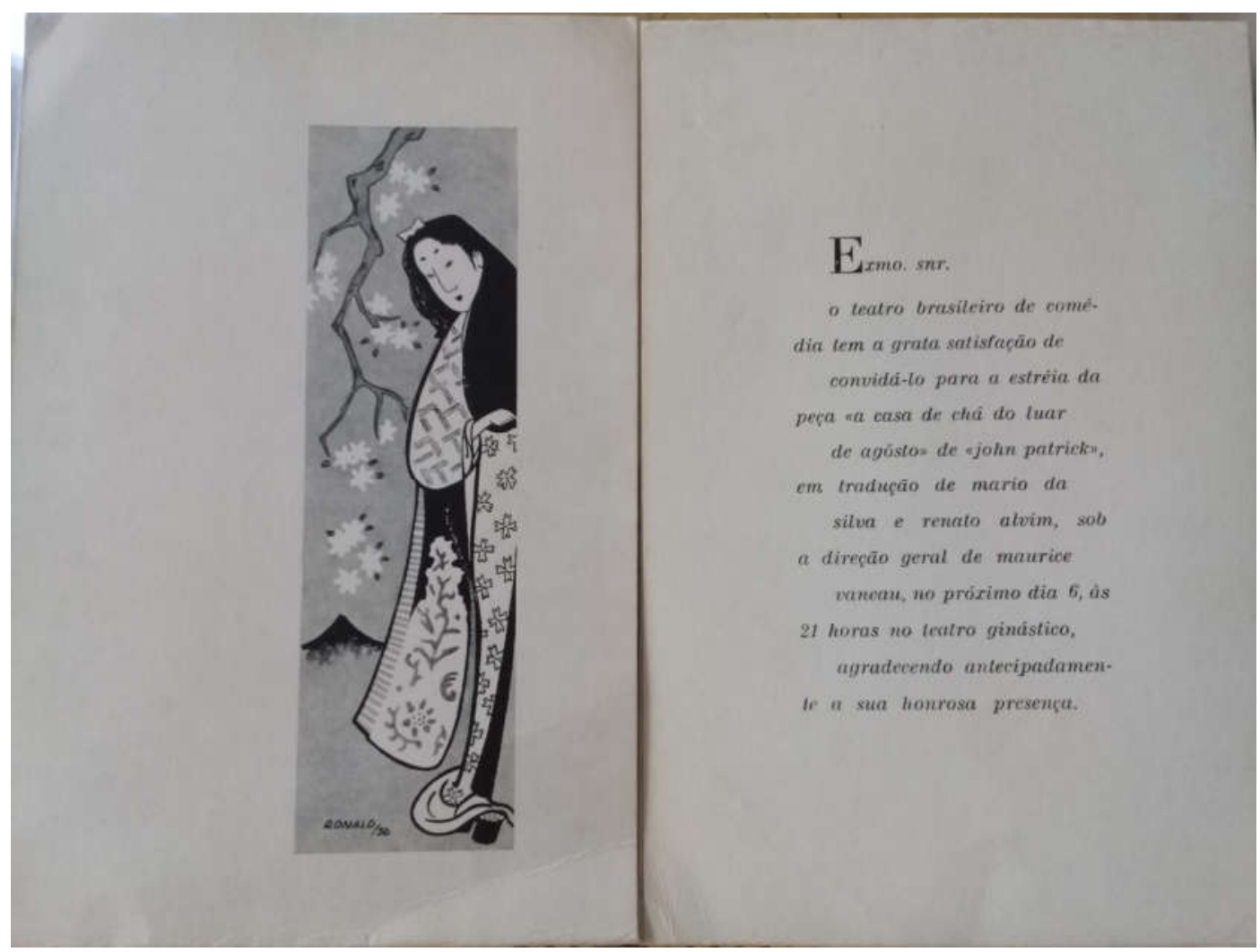

Imagem 18 - Convite para estréia de "Casa de Chá do Luar de Agosto", primeira direção de Maurice Vaneau no TBC (Acervo Gouvêa-Vaneau)

Os novos diretores da casa começam com montagens de fôlego: Gianni com uma nova tragédia de Jean Anouilh, "Eurydice”, com Cacilda Becker e Walmor Chagas, e Vaneau com "Casa de Chá do Luar de Agosto", de John Patrick. Porém, ambas montagens tiveram destinos diversos, ainda que de certa forma coincidentes entre si.

${ }^{215}$ SILVA, 1989, p. 111
${ }^{216}$ Ibid., p. 112 
Vaneau experimentou êxito na sua construção cênica tendo tido uma quase unânime aceitação de seu estilo, pois Décio de Almeida Prado considerava “(...) brilhantíssima comédia um dos maiores êxitos do $\mathrm{TBC}^{\natural 217}$, em um entusiasmo que já parecia estar se tornando praxe, e ainda que Miroel Silveira revelasse certo fastio com o "estilo TBC" ao dizer que os atores antes dele eram "proibidos de inflexionar", considera que Vaneau “(...) parece ter imprimido uma riqueza nas gamas musicais (que mostra) um caminho novo aberto aos jovens atores da encenação"218.

Gianni Ratto, no entanto, teve uma programação um tanto errática em seu início no TBC. Por causa do sucesso de "Casa de Chá..." - trezentos e cinquenta mil cruzeiros de renda semanal, e mais de sessenta e um mil espectadores ${ }^{219}$ - a ser levado logo em seguida ao Rio, ensaios de Ratto para "Crime e Castigo", de Dostoiévski, são interrompidos por pedido de Zampari por uma peça mais leve para acompanhar o sucesso anterior - pedido atendido por Ziembinski, que encena "Divórcio para Três", de Sardou. A peça marca a estreia de Fernanda Montenegro, contratada junto de Nathalia Thimberg - que estreou numa montagem mal sucedida de "O Sedutor", de Diego Fabbri, logo no início do ano. Enqunto Nathalia Thimberg foi chamada a partir dos testes realizados no Ginástico do Rio, Fernanda Montenegro acumulava experiências anteriores junto a seu marido Fernando Torres - nesse caso, acabou contratada com status diferente de Thimberg, naquele momento ainda estreante profissionalmente.

A estreia de Ratto acaba por acontecer apenas em agosto de 1956, mas apesar da boa impressão da crítica para sua "Eurydice", o público não compra mais tanto a ideia de assistir a um texto clássico - apenas três mil e seiscentos assistem à peça, com $32 \%$ de ocupação média da sala na temporada -, a sua programada temporada no Rio é interrompida por um rompante onde a cenografia acaba queimada por ordem de Zampari após desentendimento com Ratto" (GUZIK, 1986, p. 139). Ou seja, mesmo quando de um êxito de público ou de crítica, é de se pensar no quanto o TBC, apesar de buscar com outros nomes a mesma fórmula exitosa do início, parecia estar perdendo seu viço em meio às disputas internas.

\footnotetext{
${ }^{217}$ GUZIK, 1986, p. 130

${ }^{218}$ apud SILVA, Op.Cit., p. 112

${ }^{219}$ Notícia do jornal Tribuna da Imprensa de 1 de março de 1956 dizia que eram vendidos lugares extras para as sessões desta peça, completando 390 entradas no total, para acomodar a demanda em muitos fins de semana da temporada.
} 

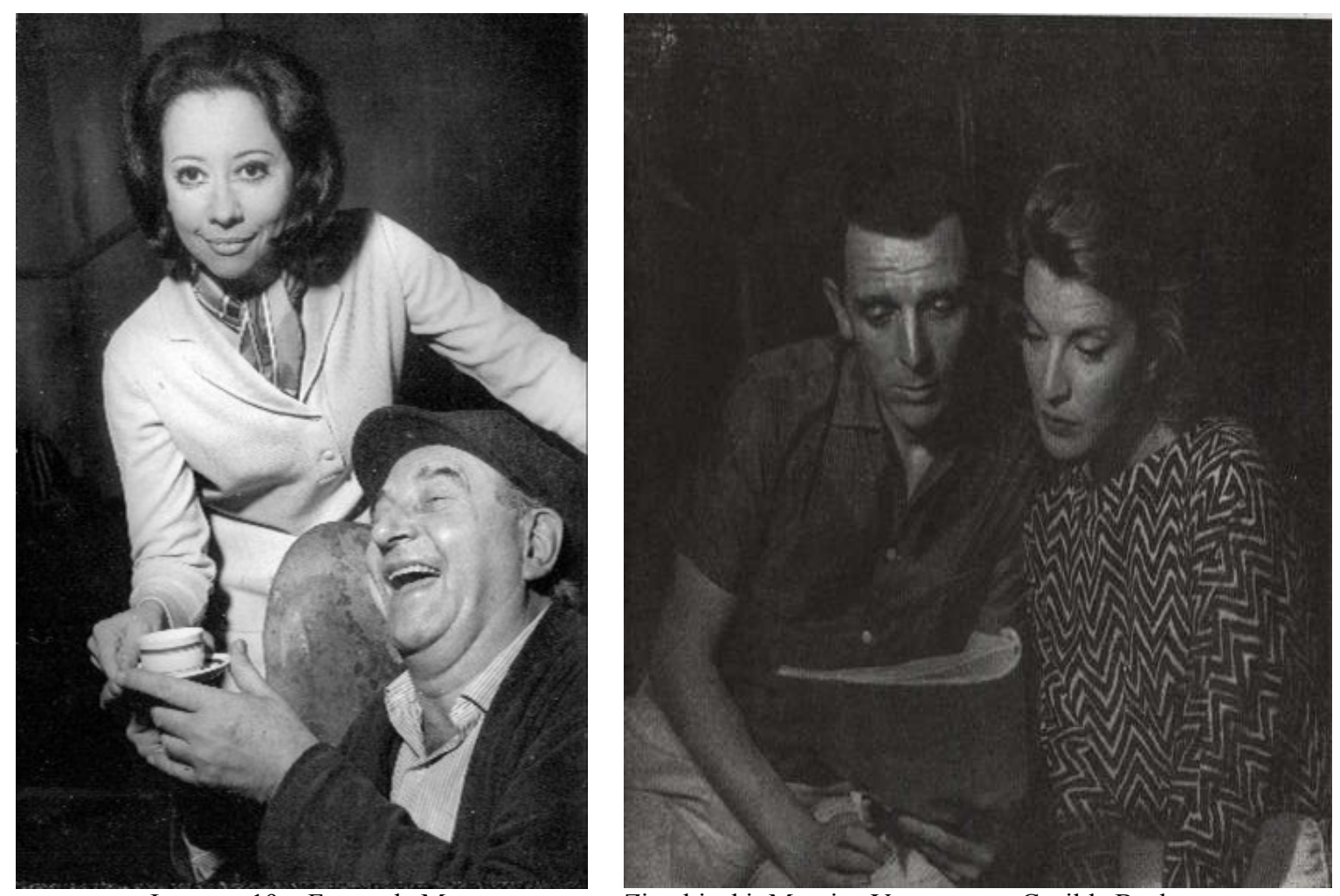

Imagem 19 - Fernanda Montenegro com Ziembinski; Maurice Vaneau com Cacilda Becker

Em meio a isso, o ano de 1956 foi especialmente prolífico quanto ao debate das políticas públicas de teatro. Havia uma sensação de aparente liberdade democrática com a posse de Juscelino Kubitschek como presidente, apesar de, como é destacado pelo próprio em entrevista à revista Paratodos de junho daquele ano, também houve uma violenta oposição à sua posse com sérias ameaças à continuidade do regime democrático. Mas também havia expectativa de atendimento maior de Juscelino a demandas do teatro, pelo fato dele haver chamado Paschoal Carlos Magno para ser seu chefe de gabinete.

Mas o máximo de aceno que ele deu ao teatro no seu início de governo revelouse na mesma entrevista, quando Kubitschek chama a atenção para projeto de lei proposto na Câmara dos Deputados, com apoio do Executivo, em que se propunha que a censura e classificação etária de obras culturais passasse do controle do Departamento de Polícia para o do MEC. O projeto tal como proposto acaba não aprovado em sua gestão, mostrando os duros embates travados no governo para fazer valer suas propostas de políticas públicas. Como exemplo do que poderia ser feito, se faz necessário prestar atenção no que o governo anterior de Café Filho, ainda que em mandato de pouco mais de um ano, fez em prol da arte teatral nacional. 
Ele editou em fevereiro de 1955 uma emenda ao decreto que instituiu os critérios de censura artística em 1946. Porém, não para modificar os parâmetros censuráveis, mas para incluir a televisão dentre os meios a serem fiscalizados - afinal, ela ainda não existia no país quando da edição original da lei -, e para desobrigar autorização da SBAT para encenação de uma peça registrada na entidade, podendo ela ser negociada entre as partes envolvidas para posterior consulta e pagamento à SBAT quando da aceitação mútua dos termos. Apesar de parecer algo ínfimo para o teatro nacional, esse movimento acabou dando novo impulso à "Lei 2 por 1", com autores contemporâneos oferecendo de forma direta seus textos às companhias.

É nesse contexto que a tal lei de ajuda à encenação de autores nacionais tem a sua discussão cada vez mais polarizada. Entre os que a apoiam, há nomes como de Maurice Vaneau, que evoca o apoio institucional no seu país de origem, a Bélgica, em relação a autores nacionais. Como exemplo, Vaneau destaca que cento e oito mil cruzeiros apenas em direitos autorais vindos do Brasil foram destinados para autores ligados ao Teatro Nacional da Bélgica no ano de 1955. Entre os que se posicionavam com ressalvas, estavam Maria Della Costa e Sandro Polloni, que diziam que a lei deveria estar condicionada exatamente a uma subvenção governamental para se produzir as montagens. Entre os que a rechaçavam, Ruggero Jacobbi dizia que talvez fosse preciso conquistar o povo para o teatro para depois provê-lo com experimentações de artistas desconhecidos, ou peças que mesmo sendo nacionais estariam desconectadas de sua realidade.

Com esse debate acalorado na ordem do dia do meio teatral, pode-se perceber que o papel de instituições como a SBAT e o próprio MEC continuava sendo altamente questionado quanto à promoção e produção de peças nacionais, pelo fato de não ficar claro para todos os envolvidos a responsabilidade pelo atendimento a essas necessidades. Ao mesmo tempo, o mercado seguia de forma independente da máquina governamental. Levantamento feito junto à SBAT pelo jornal $A$ Noite em 28 de fevereiro de 1956 trata dos valores de direitos autorais gerados por companhias nacionais, e revertido a autores brasileiros e estrangeiros, desde o início da vigência da "Lei 2 por 1": 


\begin{tabular}{|c|l|l|l|l|}
\hline \multicolumn{5}{|c|}{ DIREITOS AUTORAIS SOB LEI 2 POR 1 } \\
\hline Ano & $\begin{array}{c}\text { Valor } \\
\text { arrecadado } \\
\text { para SBAT }\end{array}$ & $\begin{array}{c}\text { Direitos para } \\
\text { Autores Nacionais }\end{array}$ & \multicolumn{1}{|c|}{ Estrangeiros } & Outros* \\
\hline 1952 & Cr\$ 8 milhões & Cr\$5,3 milhões & Cr\$ 1 milhão & 1,7 milhão* \\
\hline 1953 & Cr\$ 9 milhões & Cr\$ 6 milhões & Cr\$2,3 milhões & 700 mil* \\
\hline 1954 & Cr\$ 10,5 milhões & Cr\$6 milhões & Cr\$3 milhões & 1,5 milhão* \\
\hline 1955 & Cr\$ 15,2 milhões & Cr\$ 9 milhões & Cr\$6 milhões & 200 mil* \\
\hline
\end{tabular}

* pagamento a outros envolvidos na negociação da cessão das peças, como agentes, editoras, tradutores

Uma das críticas dessa lei era a de que fortaleceria a ação de empresários, pelo fato das companhias se sentirem obrigadas a encenar um autor brasileiro qualquer para fazê-la cumprir. Porém, esse levantamento mostra uma grande variação no pagamento a agentes externos às companhias, com uma forte tendência de queda em 1955. Mesmo para quem negociava direitos estando dentro de sua estrutura, como era o caso de Zampari, a lei pareceu ter causado prejuízos. Ele em pessoa era quem fazia esse papel de empresário pelo TBC, viajando logo depois da posse de Vaneau no teatro por seis meses pela Europa e Estados Unidos, para assistir peças que pensava poderem interessar ao TBC. Tal era sua confiança no trabalho de Vaneau que este foi designado como diretor geral em sua ausência, lidando também com as questões administrativas.

Separando por gênero esse montante, entre o teatro de revista e o dramático, ficam evidenciados alguns padrões. Em 1954, dentre os valores distribuídos em direitos autorais para autores nacionais, $77 \%$ foram para as revistas e 33\% para o teatro dramático. Na classificação do gênero dramático, o levantamento considera em separado as comédias feitas por companhias tradicionamente tidas como dramáticas, como o TBC. Entre essas, as comédias brasileiras arrecadaram 50\% de direitos em relação a comédias estrangeiras encenadas por elas, sendo que a peça classificada como comédia que mais arrecadou dentre todas justamente "Santa Marta Fabril S.A.".

Por esse raciocínio, mesmo com as comédias estrangeiras ocupando, segundo o levantamento, 60 a $70 \%$ da programação das grandes companhias pesquisadas, a comédia nacional arrecadou mais. Ainda que seja preciso pensar que esse foi um movimento extemporâneo graças ao fenômeno de bilheteria da peça de Abílio Pereira de Almeida, o levantamento sustenta a impressão de que empresários e diretores ainda preferiam trabalhar com as traduções de autores estrangeiros em detrimento da aposta nos autores nacionais. Além disso, as poucas representações de peças nacionais nessas 
companhias acabam estimulando uma concentração dos ganhos, algo que não acontece da mesma forma no teatro de revista, que apesar de render mais em direitos autorais tem sua renda mais pulverizada em diversos autores.

Em meio a esse debate, o governo federal cria em março de 1956, quase dois anos depois do fim sua última companhia estatal, o Teatro Nacional de Comédia (TNC). Uma diferença fundamental para as tentativas anteriores é que os recursos para a implantação da companhia estariam desde o início garantidos por lei dentro do orçamento do ministério. Liderada por Edmundo Moniz, a chegada da companhia foi cercada de desconfiança por ela ter sido designada sem uma sede própria pronta a recebê-la. Mesmo assim, ela consegue estrear em novembro de 1956 no teatro Maison de France no Rio de Janeiro, com um curioso programa que juntava "Memórias de um Sargento de Milícias", um texto de Bernard Shaw inédito no país e a conjunção de três peças nacionais em um ato, entre elas "Pedro Mico", de Antonio Callado, e "Jogo de Crianças", de João Bethancourt, diretor artístico da nova companhia.

Os outros dois autores nacionais contemporâneos escolhidos para compor a abertura acabariam por marcar época na renovação teatral daqueles tempos, Jorge Andrade e Antonio Callado. Mas era possível vislumbrar pelas primeiras escolhas que a companhia não se limitaria a ter conteúdo exclusivamente nacional - pouco depois, ela dobraria a aposta em autores estrangeiros desta vez encenando "Nossa Cidade", do estadunidense Thornton Wilder. Na verdade, sequer formalmente ela seria totalmente brasileira, com Gianni Ratto assumindo em 1957 a direção artístico-geral do TNC, numa junção de funções mais completa em relação às que exercia no TBC.

Não foi apenas no âmbito federal que o debate sobre as políticas e ações do Estado para o teatro nacional se evidenciaram. O Governo do Estado de São Paulo tentava desde 1954 iniciar uma política teatral que fosse duradoura. Naquele ano, acabou por fundar o primeiro Conservatório Dramático e Musical do interior em Tatuí, gerido por um Conselho Consultivo com pessoas de várias expressões artísticas, para atendimento de demandas do interior que sempre se viu negligenciado pelas políticas públicas, especialmente na área da cultura. 
Mas a dotação orçamentária para o pleno funcionamento do local se transformou numa contenda, pois após sua fundação a única verba garantida para a instituição veio de um decreto de fevereiro de 1956 que tratava de concessão de subvenções a entidades artísticas com participação do Estado - sendo que um mês antes a mesma concessão já havia sido dada para estabelecimentos particulares nessas condições. Até então, o Conservatório se mantinha basicamente por dotações legislativas saídas dos gabinetes dos deputados da região.

A partir das ações de Jânio, a política pública do estado que melhor se adequou às necessidades do meio teatral paulista foi a criação em agosto de 1956 da Comissão Estadual de Teatro (CET), onde o governador frisava no decreto de criação suas intenções “(...) visando ao estímulo e expansão da atividade teatral em todo o estado",220. A primeira ação da CET foi elaborar um Plano Estadual de Teatro, fazendo um mapeamento de teatros públicos e particulares concluído a ponto de ter destinação de quinze milhões de cruzeiros para sua execução em 1957, e a abertura junto aos bancos estaduais de um Plano de Concessão de Empréstimos às Empresas Teatrais, linha de crédito exclusiva para fomentar as atividades das companhias. Além disso, entre agosto e setembro de 1957 foram editados decretos pela Secretaria de Governo ${ }^{221}$ em conjunto com a CET para destinação de um milhão de cruzeiros para atender demandas específicas ao teatro, a saber:

- Financiamento de companhias (profissionais) e grupos teatrais (amadores) para visitarem 50 cidades do interior do estado em turnê

- Compra de sessões de determinados espetáculos na Capital para oferta-los a preços populares (ingressos a preço subsidiado)

- Auxílio a três instituições teatrais de renome: Casa do Ator (assistência), Escola de Arte Dramática (ensino) e Federação Paulista de Amadores Teatrais

Para companhias profissionais contempladas com o auxílio para viajarem pelo interior do estado, houve um novo decreto através de leis especiais para que esse auxílio se estendesse a outros fins além das viagens e dos espetáculos comprados pelo Estado, para que pudessem ser utilizados na manutenção cotidiana de tais companhias.

${ }^{220}$ QUADROS, 1958, p. 129-30

221 Ibid., p. 175-6 
Foi desse modo que então o TBC recebeu seu primeiro auxílio governamental oficial. Junto ao TBC, também receberam tal subvenção o Teatro dos Novos Comediantes $^{222}$, o Teatro de Arena, o Teatro Popular de Arte - como representantes do novo teatro paulistano -; a Cia. Nydia Lícia-Sergio Cardoso, oriunda do TBC; e remanescentes da primeira metade do século XX, como e a Cia. Raul Roulien.

Alem dessas ações, até outubro de 1957 parte do orçamento foi destinado para implantação do TUSP (Teatro dos Universitários de São Paulo, hoje incorporado à USP), e também foram concedidos recursos para realização da Bienal de Artes Plásticas do Teatro ${ }^{223}$ e o prêmio Governador do Estado, que concedia trezentos mil cruzeiros ao vencedor. Por fim, em meio à concretização de suas primeiras ações, acabou curiosamente vindo da CET, e não do MEC como esperado no início de 1956, uma negociação junto à Divisão Central de Diversões Públicas (DCDP) da Secretaria de Segurança do Estado para que houvesse flexibilização das regras classificatórias e de censura às atividades teatrais dentro dos limites do Estado de São Paulo. Isso permitiu uma relativa suavização geral no julgamento das peças de teatro, principalmente saídas de São Paulo, onde essa resolução informal estava vigente.

Para a temporada de "Gata em Teto de Zinco Quente", de Tennessee Williams, dirigida por Vaneau e estreada em São Paulo no fim de 1956 com Ziembinski, Cacilda e Walmor em fortes papéis principais, havia um questionamento quanto à natureza da peça, que misturava aspectos morais com políticos no período do chamado "macarthismo" 224 nos Estados Unidos de uma forma que poderia soar pouco sutil por muitos setores - muito diferente do caso de "Casa de Chá...", onde a tensa convivência entre japoneses e Aliados do exército dos Estados Unidos durante a Segunda Guerra foi colocada em chave mais leve.

\footnotetext{
${ }^{222}$ Esse era o nome fantasia do Teatro Oficina em seu início, herdado do local onde se reuniam: a casa do grupo teatral espírita Teatro dos Novos Comediantes; porém, como o grupo do Oficina se estruturou apenas em 1958 (SILVA, 1981, p. 17), provavelmente foi o grupo espírita que recebeu tal subvenção.

${ }^{223}$ Concebida junto à Bienal de Artes a partir de 1957, teve prêmio final vencido em sua 1a edição por Mario Francini, cenógrafo do TBC de 1952 a 1959.

$224 \mathrm{O}$ "macarthismo" foi uma política não-oficial do governo dos Estados Unidos liderada por membros de agências de inteligência estatal e do legislativo, principalmente o senador Joseph McCarthy, onde se buscava o expurgo de pessoas acusadas de serem comunistas ou de "má influência moral", como homossexuais, de quaisquer locais de influência pública, atingindo particularmente áreas artísticas e do jornalismo, além do funcionalismo.
} 
Mesmo que a peça tivesse vindo para São Paulo logo após estrondoso sucesso na Broadway, chamando a atenção do público que queria ver "a peça do momento", receava-se que a temporada no Rio de Janeiro poderia ser prejudicada por cortes em falas ou supressão de cenas inteiras. O chefe da Censura Teatral pela segunda metade da década de 1950, Hildon Rocha, conhecido por sua intransigência com aspectos nas obras por ele analisadas que pudessem aludir ao "comunismo" ou à dita "imoralidade" exatamente o conteúdo retratado por Williams nessa peça - chegou a fazer declarações a respeito de sua postura como censor, em entevista pouco antes do início da temporada de "Gata..." no Rio:

Até agora, sob minha direção, a censura não proibiu uma só peça ou filme, embora tenho encontrado em alguns elementos do teatro de revista certa prevenção, talvez pelas diferenças de gosto artístico e formação ética. Sendo o teatro um gênero literário, não vejo como deva ser transformado numa escola 'de degradação e mau gosto' pois além de ser uma posição justa, é também legal, porque a lei sobre a censura manda proibir 'ofensa ao decoro público' e muitas outras coisas, inclusive aquilo que induza aos maus costumes. Exercer a censura contra o despudor é um ato legal, inclusive amparado no parágrafo constitucional. ${ }^{225}$

Hildon Rocha trazia uma interpretação por demais literal do artigo 41 do decreto de 1946 que instituiu a censura pós-Estado Novo, tentando utilizar-se dele a cada momento que achasse propício pelo fato de tal artigo não ter sido vetado em nível federal. Porém, as suas ameaças de endurecimento não surtem muito efeito prático pelo fato de que a própria censura pura e simples, com veto a obras que seriam consideradas como passíveis de serem proibidas segundo esse artigo, já estava arrefecida há algum tempo, restando a agentes como ele usarem do artifício da classificação etária para maiores, apesar de que mesmo isso não era usada em todos os casos. Levantamento das peças analisadas de 1954 até 1957 pelo Departamento Federal de Segurança Pública ${ }^{226}$ mostrava que havia uma variação entre 50 a $60 \%$ de peças que acabaram classificadas como próprias apenas para maiores de 18 anos.

${ }^{225}$ ROCHA, Hildon. Sobre a imoralidade do nu: o novo diretor da censura esclarece sua posição. In: Revista Visão, São Paulo, 15 fev. 1957, apud GARCIA, 2009, p. 15

${ }^{226}$ Ibid., p. 16 
Porém, nesse mesmo período teria havido apenas uma proibição total de obra nacional apesar de tais restrições ${ }^{227}$. A abordagem considerada então menos rígida a respeito das peças de teatro, assim como também em relação à presença de menores de idade no palco, contribuiu para comentário reproduzido na Revista da Semana de 25 de maio de 1957 quando da estréia de "Gata..." no Rio de Janeiro, a respeito do que esta publicação considerava uma nova abordagem da censura para com as obras teatrais:

Reprovamos aqui a dubiedade de atitudes do censor Hildon Rocha em relação ao teatro de revista. Nada mais justo do que cumprimenta-lo, agora, pela sua tolerância com a linguagem de Tennessee Williams. O mesmo pode ser dito do juiz Rocha Lagoa, que permitiu a participação de menores no espetáculo.

Porém, enquanto o TBC se via de alguma forma livre de censura ou perseguição quanto ao conteúdo de suas peças, em meio à temporada de "Gata...", o Teatro Ginástico pegou fogo em 10 de maio de 1957, em um incêndio mais violento do que o ocorrido na sede do TBC em São Paulo. Além dos prejuízos para a companhia, calculados em dez milhões de cruzeiros pelo fato de todo seu interior ter sido tomado pelas chamas, ainda ocorreu no local a morte de um eletricista, Jaime Onildo Cabral, que dormia no teatro. Apesar de inicialmente pensarem em dez dias para a recuperação da atividade, a verdade é que o trauma foi maior, deixando incerta a continuidade do projeto do TBC no Rio.

Com esse drama, a comoção e disposição de apoio de autoridades ao teatro face à sua situação acabou sendo imediata, e tambem mais ampla e forte que no incêndio do TBC em São Paulo há dois anos antes. O presidente Kubitschek mandou seu chefe de gabinete Paschoal Carlos Magno cuidar da ajuda inicial e agendou reunião no dia seguinte, após voltar de viagem, para tratar do futuro próximo da companhia. Nessa reunião estava presente o prefeito do Rio, Negrão de Lima, que prontamente cedeu o Teatro Muncipal sem custos para continuidade da temporada de "Gata...", além de prestar assistência para encontrar outro local que servisse de sede provisória, com o TBC se abrigando a partir dali no Teatro Maison de France quando no Rio de Janeiro.

\footnotetext{
${ }^{227}$ A história dessa única peça vetada no Rio entre 1954 e 57, "A Verdade Toda Nua”, de Lucio Fiuza, é de certo modo intrigante: Segundo o jornal Correio da Manhã de 20 de janeiro de 1955, a peça foi encenada com sucesso no fim de 1954 pela companhia Raul Levy no Teatro Amazonas, em Manaus, e em janeiro de 1955, Fiuza recebeu prêmio da Prefeitura do Rio de Janeiro por "Doze degraus para baixo" em um concurso de peças infantis. Porém, em 15 de fevereiro, parecer da censora Maria Penna (apud GARCIA, 2009, p.18) simplesmente proibiu “A Verdade Toda Nua" de estrear no Rio.
} 
A partir de São Paulo, desta vez foi o então governador Jânio Quadros que se manifestou, ainda que indiretamente. Ele estava no mesmo cargo quando o TBC havia se incendiado na Bela Vista, entretanto ele não havia naquele momento se colocado à disposição, deixando que o prefeito interino que entrou no posto em seu lugar manifestasse um apoio que não poderia conceder. Agora, respondendo a apelo direto expresso pela CET quanto à importância da continuidade do trabalho do TBC, o governador assinou autorização de concessão de trezentos mil cruzeiros à companhia.

Se a crise financeira do TBC parecia estar se encaminhando para um sentimento de alívio em relação à sua existência, como se sempre estivesse ali mas se convivesse com sua presença de alguma forma, ela prosseguiu forte e desestabilizadora num âmbito também sensível para seus administradores. $\mathrm{O}$ elenco do TBC continuava em disputas de protagonismo e com sua proposta se tornando cada vez mais anacrônica perante à crítica, urgindo por uma renovação. Ela acontecia também dentro do TBC, mas não em prol da companhia, mas em movimentos que mostravam o quanto se buscava respirar novos ares para a melhor expressão dos anseios dos artistas presentes.

Com isso, as saídas prosseguiam e deixavam marcas profundas para o futuro da companhia. E esse sentimento tambem foi provocado por uma das pessoas fundamentais para a formação inicial da companhia. Ainda em 1957, Cacilda Becker sentia-se sendo cada vez menos exigida em sua busca pelo perfeccionismo no palco, fazendo uma peça por ano na casa desde 1954, sempre se colocando à disposição dos gostos dos diretores. E como esses diretores eram novos para ela, com a exceção de Ziembinski, com efeito ela se sentia pouco integrada à nova engrenagem que se desenhava na companhia.

A maneira encontrada para se sentir novamente protegida a ponto de dar o pleno de si no palco, mais do que pensar nos afetos que a cercavam como sua irmã Cleyde Yáconis e seu marido Walmor Chagas, foi a mesma encontrada por colegas antigos de TBC de quem era próxima e que buscaram outros caminhos. E assim Becker colocou à diretoria do TBC sua proposta de fundar uma nova companhia. Como Adolfo Celi, ela tambem acertou com a SBC um acordo de transição a ser executado até o final do corrente ano, que envolve apresentações finais com o TBC tanto no Rio como também 
em São Paulo, em temporadas consecutivas de "Adorável Júlia", de Sauvajon, em novembro e dezembro de $1957^{228}$

Os objetivos iniciais de Cacilda Becker na sua nova companhia incluíam trabalhar mais com autores e artistas brasileiros, além de técnicos e diretores nacionais. Mas isso não parecia um alinhamento à estética dos novos grupos combativos paulistanos daqueles tempos como o Arena e o Oficina, mas uma continuidade do processo de redirecionamento das companhias da época motivadas não apenas por suas convicções estéticas, mas pelo maior ou menor alinhamento à legislação vigente. No caso de Cacilda Becker, isso se revelou logo no anúncio de lançamento de sua companhia no Teatro Maria Della Costa em dezembro de 1957. Ela sentia sobre si pressões maiores para fazer valer o cumprimento da "Lei 2 por 1", especialmente de uma interpretação de seu artigo $2^{\circ}$ que dizia que, para se estrear uma nova companhia, era preciso fazer seu lançamento com um autor nacional como condição para obter sua licença.

Walmor Chagas, que acompanhou a esposa na formação da nova companhia colocando grande parte de seu patrimônio e de sua família na sua composição ${ }^{229}$, coloca que essa pressão fez com que pensassem em mudar o plano de estrear com "Longa Jornada Noite Adentro”, de Eugene O’Neill, para um texto encomendado a eles pelo então ascendente autor paraibano Ariano Suassuna, "O Santo e a Porca". Eles ensaiaram os dois textos no Rio de Janeiro, concretizando outro dos planos iniciais de Cacilda, o de não ter uma sede fixa para ter maior liberdade de sair em turnês ${ }^{230}$. Em 5 de março de 1958, é finalmente realizada a estreia da Companhia Cacilda Becker com "O Santo e a Porca" no Teatro Dulcina de Moraes, no Rio.

Em entrevista a Sabato Magaldi, publicada na revista $A$ Cigarra de agosto de 1957, Cacilda Becker dizia se sentir encorajada a tomar outro rumo em sua carreira pela trajetória de seus antigos colegas de TBC fora da companhia. Ao passo que o grupo com quem havia convivido por tanto tempo tomava nova feição, ela sentia que os novos elementos do TBC, formados por pessoas trazidas por Gianni Ratto e Maurice Vaneau

\footnotetext{
${ }^{228}$ A temporada de "Adorável Júlia" em novembro de 1957 aconteceu em São Paulo no palco do Teatro Maria Della Costa, alugado a Zampari, para não atrapalhar a temporada da peça "Rua São Luiz, 27, 8응 andar", então em cartaz no TBC com bastante sucesso; in: GUZIK, 1986, p. 157

${ }^{229}$ BARROS DE ALMEIDA, 1987b, p. 16

${ }^{230}$ Ibid., p. 55
} 
quando de suas chegadas ao teatro, “(...) formavam grupos secundários, que não colaboravam com a melhoria do teatro" ${ }^{231}$, fazendo-a se sentir alijada e até mesmo excluída dentro da companhia. Nesse relato bastante franco e confessional, ao mesmo tempo bastante objetivo em suas formulações e emotivo em relação à revisitação de sua própria carreira, Cacilda Becker trata também dos aspectos que para ela fizeram o TBC se tornar uma máquina industrial para a cultura teatral brasileira, colocando o que considera terem sido as razões definitivas para sua saída da companhia:

Inicialmente servia-me do instinto, mas como tudo estava no começo, sobrava-me tempo para construir em paz. Todas as minhas forças boas ou más, eu as coloquei a serviço do teatro. Conquisteia confiança de Franco Zampari, Adolfo Celi, dos colegas e todos me deram muita força. [...] Todas as sugestões que partiram de mim, opiniões ou mesmo qualquer ação se destinavam a defender o grupo, fechando sobre si mesmo para que pudesse produzir mais. Movia-nos uma mentalidade única, despida do espirito de competição. [...] Nesse ambiente (com os novos que chegavam), eu já era suspeita. Não lidava mais com principiantes. Minha atuação poderia parecer inspirada na rivalidade ou na inveja. As consequências desse clima seriam fatalmente prejudiciais ao TBC. [...] Fiquei assim desencantada como atriz e meu amor pelo TBC foi ferido. Apesar disso, em 1957 propus à direção do teatro que organizasse um grupo com os atores que de um certo modo estavam encostados e nós viajaríamos juntos. Teríamos $20 \%$ do lucro da bilheteria, ficando a empresa com os $80 \%$ restantes e os encargos dos salários. Vaneau considerou absurda a proposta - a ele (como diretor artístico) caberia idêntico direito, que aliás foi reconhecido. Verifiquei afinal que nada mais tinha a ver com o $T B C .^{232}$

Essa ânsia de Cacilda Becker por liberdade e renovação, enquanto mostrava grande lucidez como atriz e empresária de si mesma, se expressou de muitas maneiras na fundação da nova companhia. Em paralelo a isso, o TBC tentou se alinhar a esse momento à sua maneira. Primeiro, encenando "Provas de Amor", de João Bethancourt, que apesar de bem feita se revela dos maiores fracassos da história na casa - pouco mais de $20 \%$ de ocupação média em quarenta apresentações -, e depois com dois textos nacionais juntos em novo projeto de Teatro Experimental no segundo andar do prédio, antes ocupado pela EAD. Um dos textos ("Do outro lado da rua") foi assinado por Augusto Boal, que após essa passagem pelo TBC ajudou na consolidação do Arena

\footnotetext{
${ }^{231}$ BARROS DE ALMEIDA, 1987b, p. 12-3
}

232 Ibid., p. 64-5 
como centro da vanguarda teatral ao trazer uma estética e um público novos ao teatro, predominantemente mais jovem.

É possível que esse embate contínuo quanto à valorização dos autores nacionais, e do teatro brasileiro em geral, tenha acabado por nortear de um modo ou outro todos os grupos durante os anos 1950. A partir dessa questão, pressentia-se que estes seguissem certas normas e padrões para designar se faziam uma arte "engajada" ou "alienada". Enquanto isso, os elementos fundamentais para formação de novos artistas - técnicas teatrais de pesquisa e análise, resumidos no trabalho dos diretores estrangeiros pelos princípios da “(...) racionalidade, homogeneidade, disciplina, regularidade" ${ }^{, 233} \mathrm{em}$ busca de métodos efetivos de conexão com o público - acabavam de algum modo desconsiderados no decorrer do processo de criação. Nesse sentido, o próprio TBC ainda buscava uma nova fórmula própria, ainda que repetindo certos padrões de ação.

Após tantos fracassos consecutivos, que forçam a saída de Vaneau de seu posto como diretor no teatro, foi a junção entre um texto nacional escrito por Abílio Pereira de Almeida e um novo diretor estrangeiro que retira o TBC de uma situação calamitosa. Uma fórmula tão usada que poderia passar despercebida novamente pelo público, mas que resulta num conjunto de sobrevidas ao núcleo duro do teatro. A estreia do italiano Alberto D'Aversa, que como Celi também teve uma passagem por Buenos Aires ${ }^{234}$, acaba por tornar-se auspiciosa com "Rua São Luiz, 27, $8^{\circ}$ Andar", ainda que tenha havido uma dissonância entre o gosto da crítica, que em geral não gostou da peça ${ }^{235}$, e do público, que compareceu em peso com cinquenta e duas mil pessoas na temporada.

Esta peça, e a anterior na programação do TBC ("Nossa Vida com Papai”, de Howard Lindsey e Russel Crouce), se configuram como os trabalhos mais vívidos e reconhecidos de Fernanda Montenegro nesta companhia em 1957, o que não impede que também experimente fracassos - como no mesmo ano em "Os Interesses Criados", de Jacinto Benavente, uma recriação moderna de elementos da commedia dell'arte vista

\footnotetext{
233 Baseado em termos que se repetiam em textos dos diretores do TBC Adolfo Celi, em "Antígonas"; Flaminio Bollini Cerri, em "Ralé"; e Luciano Salce, em "A Dama das Camélias", publicados nos programas dessas peças, acerca de suas ideias para a encenação teatral: in: BARROS DE ALMIEDA, 1987a, p. 15 ${ }^{234}$ Porém, diferente de Celi que andou pelos teatros amadores de Buenos Aires, D’Aversa foi diretor no Teatro Colón, o maior da cidade; in: GUZIK, 1986, p. 153

${ }^{235}$ A reação de Décio de A. Prado em O Estado de S. Paulo de 28 de julho de 1957 diz que, apesar da peça “(...) não exigir muito do encenador (seria) "bem executada, parecendo incrível que com tanta gente de talento, o TBC atravesse uma crise de organização."; in: Dionysos, 1980, p. 109
} 
por apenas quatro mil pessoas, mostrando mais uma vez que o público não parecia ver mais sentido em retomar elementos clássicos, apesar das tentativas de críticos e encenadores em virem elementos contemporâneos nesse gênero ${ }^{236}$.

Infelizmente para o $\mathrm{TBC}$, não era sempre que a repetição de fórmulas e elementos trabalhados anteriormente pela companhia dava resultado. No início de 1958, levou-se ao palco outra peça de Abílio Pereira de Almeida, chamada "A Dama de Copas", realizada enquanto os principais nomes do elenco faziam sua preparação para montagem de peça de Guilherme Figueiredo: uma recriação muito particular do mito da Matrona de Éfeso, de nome "A muito curiosa história da virtuosa Matrona de Éfeso", com nomes como Leonardo Vilar e Fernanda Montenegro junto a quase novatos que vinham ganhando destaque naquele momento, como Francisco Cuoco e Nathalia Thimberg.

Nenhuma das duas deu certo: a primeira era reciclagem de "Pif-Paf", peça com que Almeida se notabilizou nos anos 1940 junto aos grupos amadores, atraindo desta vez apenas oito mil espectadores ao TBC e com sua temporada estendida apenas pelos atrasos na preparação da peça seguinte; e a segunda, com público de três mil pessoas em trinta e cinco sessões - $24 \%$ de ocupação média na sala -, mostrou que nem mesmo com os astros da companhia naquele momento, era possível salvar-se do enfado do público com textos que emulavam temas clássicos.

Porém, o ano de 1958 prometia ser de júblio para o TBC, pela expectativa gerada quanto à preparação para comemoração de seus dez anos de atividade. A divulgação desse intento se deu em maio pela revista Anhembi, que alega ter primeiro sugerido tais comemorações para a diretoria da SBC. Para a concretização disso, houve pela própria equipe da revista Anhembi a formação de uma ampla comissão de personagens históricos do teatro da Bela Vista junto a outros que mantinham “(...) laços remotos ou recentes com o TBC",237, de maneira bastante subjetiva. O nome de todos os componentes dessa comissão, com suas respectivas funções na preparação das festividades, segue abaixo:

\footnotetext{
${ }^{236}$ Sobre a commedia como resposta do "fantástico social" frente ao teatro de então, Cf. em: JACOBBI, Ruggero. Goldoni Fundador do Realismo Social, in: Cadernos de Teatro, n. 32, Rio de Janeiro: Tablado, 1965

${ }^{237}$ Dionysos, 1980 , p. 112
} 


\begin{tabular}{|l|l|l|}
\hline \multicolumn{2}{|c|}{ COMISSÃO ORGANIZADORA 10 ANOS DO TBC } \\
\hline Comissão Executiva: & \multicolumn{2}{|c|}{ Conselho Consultivo: } \\
\hline - Ademar de Almeida Prado & - Adolfo Celi & - Danilo Bastos \\
- Amador Aguiar & - Lourival Gomes & - Orlando Nasi \\
- Aristeu Seixas & Machado & - Décio de Almeida Prado \\
- Armando Paschoal & - Antunes Filho & - Paulo Duarte \\
- Benedito Soares de Mello & - Luiz de Almeida Salles & - Delmiro Gonçalves \\
- Fabio Prado & - Antonio C. Carvalho & - Paulo Fabio \\
- Francisco Matarazzo & - Maria Della Costa & - Gastão Barroso \\
Sobrinho (Ciccillo) & - Alfredo Mesquita & - Raul Roulien \\
- J. Meira Vasconcellos & - Marina Freire & - Horácio de Andrade \\
- José Ermínio de Moraes & - Cacilda Becker & - Ruy Affonso \\
- Julio de Mesquita Filho & - Mattos Pacheco & - João Scatimbourgo \\
- Odilon de Souza & - Clovis Garcia & - Sábato Magaldi \\
- Otávio Marcondes Ferraz & - Maurício Barroso & - José Renato \\
- Teodoro Quartin Barbosa & - Carlos Vergueiro & - Waldemar Wey \\
& - Nicanor Miranda & - Sergio Milliet \\
& - Cornélio Procópio & - Sergio Cardoso \\
\hline
\end{tabular}

Fonte: GUZIK (1986); Dionysos (1980)

O modelo para se pensar essa comissão remete a como foi formada a organização do plano cultural da festa do IV Centenário da cidade de São Paulo, em 1954, prometendo ao mesmo tempo ser mais abrangente que a celebração de então por ter representantes de vários setores da sociedade, e mais efetiva quanto á maneira como as demandas teatrais seriam contempladas. Considerava-se que, mesmo com Ciccillo Matarazzo na presidência da comissão de 1954, o teatro teria ficado relegado a um papel menor na festa. Porém, uma diferença fundamental entre as duas festividades é que a primeira era de caráter público, e esta, por maiores que fossem as contribuições do TBC à sociedade, era uma festa privada restrita ao círculo fechado em torno do teatro.

Também era de se pensar qual seria o real comprometimento de todos dessa comissão, formada por "banqueiros, homens de negócios, de gente de posses, em condições, em suma, de ajudar, prestigiar tão justa e útil empresa” ${ }^{, 238}$. Muitos deles já haviam passado anos investindo no TBC para assim virem seu investimento revertido em coisas esplêndidas artisticamente, porém que lhes traziam ainda mais pagamentos e dívidas a saldar. E muitos dos artistas mencionados para a comissão consultiva, que dariam ideias do que fazer, tinham como máxima ligação com o TBC o fato de serem contemporâneos e atuarem na cidade, sem identificação formal com aquele teatro.

\footnotetext{
${ }^{238}$ Transcrição de análise sobre atuação da comissão publicada na Anhembi de novembro de 1958, apud GUZIK, 1986, p. 172; Dionysos, 1980, p. 114
} 
Assim, para fazer o evento acontecer e, ao mesmo tempo, para que ele fosse esplendoroso como Zampari pensava que o TBC merecia, pelos esforços empreendidos por ele e sua equipe, o empresário da casa parece ter mudado de tática em relação à forma que usou para captar recursos em anos anteriores. Apesar da SBC e a comissão chamada para organizar aquele momento contar com representantes de entidades privadas e indústrias dentre as que mais faturam no Brasil, Zampari parece ter resolvido que seria então o poder público que deveria ser responsável por financiar a celebração de seu empreendimento como uma grande contribuição para a cultura do país. Zampari passa a articular com todas as instâncias governamentais e federativas possíveis para que lhes fossem concedidos auxílios ou premiações sobre os quais não se pudesse incidir descontos por impostos, juros ou mesmo maiores contrapartidas.

O primeiro auxílio buscado foi junto à Câmara Municipal de São Paulo através do vereador Umberto Fanganiello. Antes do fim do ano de 1957, foi encaminhado por Zampari à Comissão de Cultura da Câmara, projeto para concessão de quinhentos mil cruzeiros ao TBC. Foi aberto processo anexado por notícias de jornal referentes à história da companhia, relatório com todas as peças encenadas e o parecer da situação jurídica da entidade. No documento enviado pela Comissão para recomendar a aprovação do auxílio através do Projeto de Lei 435/57, foi mais uma vez frisado o fato da instituição representante do TBC se apresentar como entidade sem fins lucrativos voltada ao “(...) patrocínio, amparo e difusão da arte cênica"239 na cidade e no país.

Além disso, o projeto tinha na descrição de sua finalidade maior que a razão para o pedido de tal auxílio não seria pelas comemorações de seu aniversário, mas para “(...) ajuda pelos prejuízos havidos à companhia em virtude do incêndio verificado quando em temporada no Teatro Ginástico" ${ }^{240}$, em um caso concreto de cessão direta de dinheiro público para uma empresa teatral que, apesar de ainda se alegar como sem fins lucrativos, se configurava como uma empresa privada capitalista como outra qualquer. Isso feito a título de "homenagem" pelo bem público dado ao país, onde parece valer a máxima de que os custos e prejuízos são socializados ao público, enquanto os lucros são privatizados.

\footnotetext{
${ }^{239}$ ANGELO, 2016, p. 133-4

${ }^{240}$ Idem Ibidem
} 


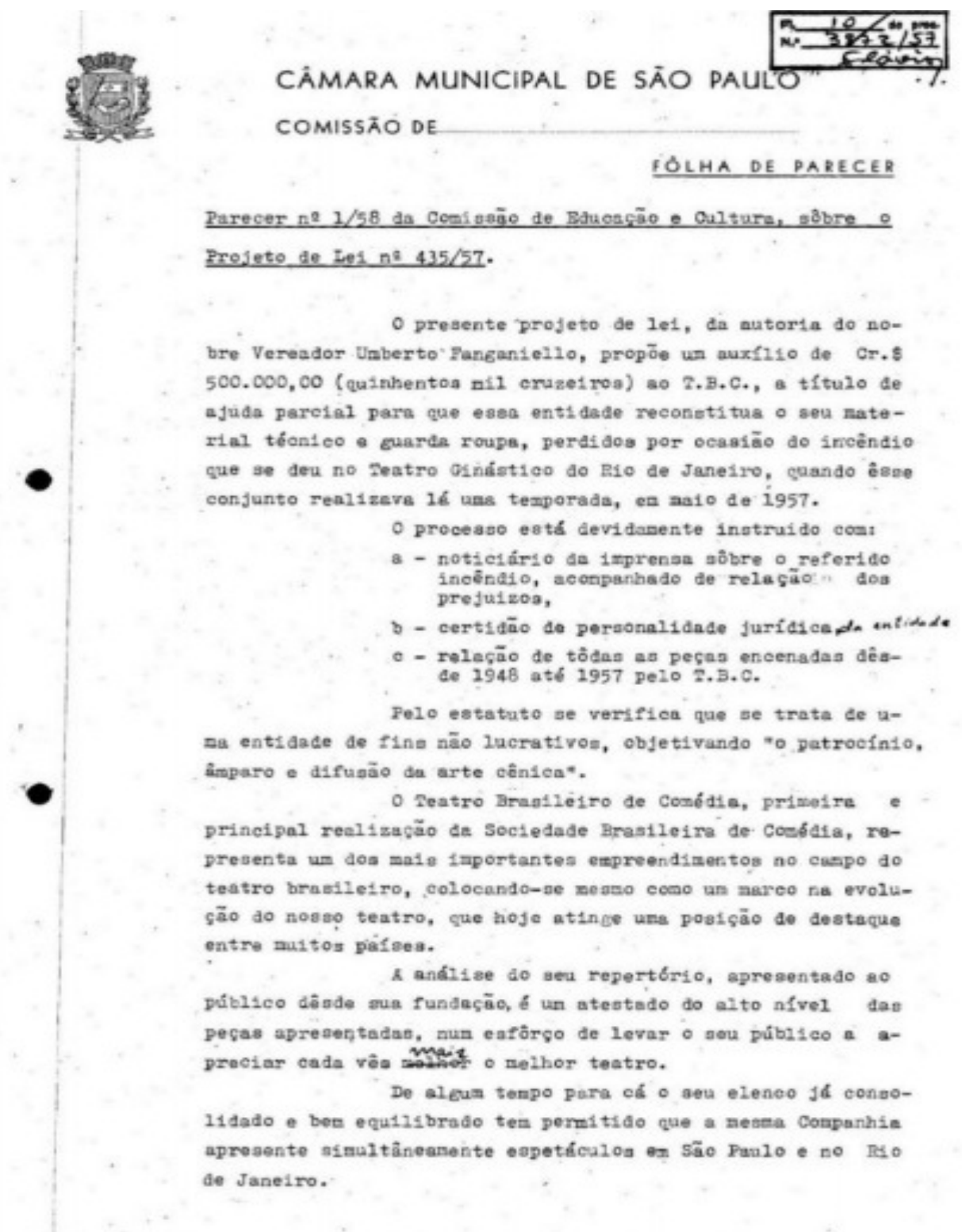

Imagem 20 - Processo aberto na Câmara Municipal de São Paulo para auxílio ao TBC (ANGELO, 2016)

Possivelmente, Zampari pediu que esse motivo estivesse destacado por pensar que não haveria uma segunda recusa de auxílio por parte da Prefeitura ao teatro, após este não ter sido auxiliado como prometido pelo prefeito da cidade quando do incêndio de 1954. Sendo assim, após passar pela Comissão da Câmara em fevereiro de 1958 e sem que fosse preciso ir ao plenário para votação, o auxílio de quinhentos mil cruzeiros pleiteado pelo projeto acabou concedido e publicado oficialmente no Diário Ofícial do Município em $1^{\circ}$ de março de 1958. 


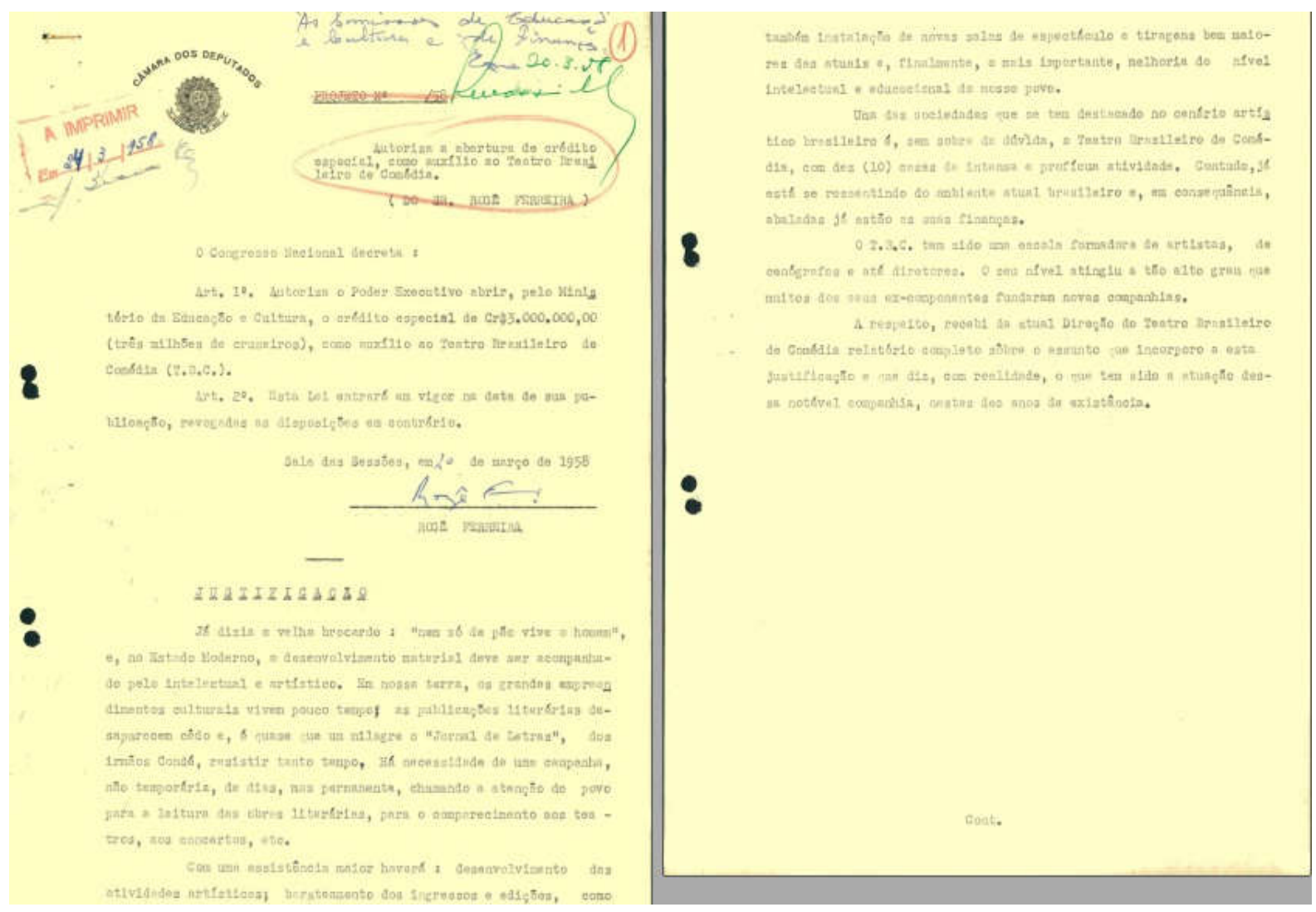

Imagem 21 - Processo aberto na Câmara dos Deputados para auxílio ao TBC em 1958; na página de rosto, encontra-se a justificativa inicial do deputado Rosê Ferreira para o projeto

Logo depois do sucesso no âmbito municipal, buscou-se ajuda na Câmara dos Deputados, localizada ainda no Rio de Janeiro pelo fato de Brasília, a nova cidade planejada por Juscelino Kubitschek para abrigar a capital, estar ainda em construção. $\mathrm{O}$ deputado Rogê Ferreira fez a proposição direta de auxílio de três milhões de cruzeiros à companhia no Projeto de Lei 3827, para que fosse analisado na Câmara dos Deputados. As justificativas do deputado à Comissão de Cultura também foram bastante alusivas à importância da companhia, colocando-a então como o sexto teatro do mundo em número de peças e representações teatrais ${ }^{241}$, aos incêndios que sofreu e ao seu "caráter de entidade sem fins lucrativos que trabalha com a promoção cultural do país".

A maior diferença quanto ao projeto apresentado antes à Câmara do município de São Paulo é um relatório mais apurado assinado pelo próprio Zampari, originalmente com sete páginas, que tratava da estrutura física e patrimonial do teatro, composta então pelos elementos que compõe a tabela a seguir:

\footnotetext{
${ }^{241}$ Os cinco primeiros seriam a Commedie Française (França), o Old Vic (Reino Unido), o Theatre Jean Louis Barrault (França), o Piccolo Teatro di Milano (Itália) e o Theatre Populaire de Jean Vilar (França)
} 


\begin{tabular}{|l|l|}
\hline \multicolumn{2}{|c|}{ PATRIMÔNIO FÍSICO TBC - $\mathbf{1 9 5 8}$} \\
\hline$>18$ camarins & $>$ Almoxarifado de guarda roupa \\
\hline$>2$ salas de ensaio & $>$ Almoxarifado de objetos de cena \\
\hline$>$ Sala de leitura & $>$ Dep6sito de cenários e móveis usados \\
\hline$>$ Carpintaria e marcenaria & $>$ Aparelhagem de luz importada \\
\hline$>$ Sala de montagem de cenários & $>5$ alto- falantes \\
\hline$>$ Atelier de cenografia e figurinista & $>$ Cr\$ 7 milhões em materiais próprios \\
\hline$>$ Salas de diretor e administradores & $>$ Cr\$2,5 milhões em figurinos \\
\hline
\end{tabular}
Fonte: Diário do Congresso - Cf. na p. 89

No documento, Zampari tambem apresentou relatório detalhando ano a ano a situação econômica da empresa, principalmente seus momentos de déficit orçamentário. Um elemento bastante destacado por Zampari em sua justificativa para esses constantes saldos negativos anuais foi o aumento da inflação e do custo de vida. Em relação ao preço dos ingressos para as sessões da casa, por exemplo, o único momento no relatório em que cita tê-los aumentado foi em 1953. O ingresso custava cento e trinta cruzeiros em 1958, com acréscimo de 45\% numa alegada variação de inflação de $90 \%$ em dez anos, justificando o que diz sobre ter "aumentado pouco" o valor do ingresso.

A questão colocada é que em 1953 houve mesmo uma medida governamental para deixar livre o controle sobre o câmbio sobre o dólar, com grande desvalorização da moeda brasileira, encarecendo custos no país. Ao comprar equipamentos importados para o TBC, os custos de manutenção do teatro seguiam apenas crescendo, chegando a fazer o custo médio de uma montagem no TBC aumentar de cem mil cruzeiros em 1948 para seiscentos mil em $1958^{242}$. No relatório ao Congresso, Zampari explicava essa lógica de funcionamento e custo das produções, tomando como exemplo uma peça de 1951, sem dar maiores detalhes sobre sua produção, mas valorizando seu trabalho:

Neste ano (de 1951), o sucesso artístico do TBC atingiu o seu climax, ao encenar a peça "A Dama das Camélias", solidificando-se então o seu conceito na opinião pública. Mas o sucesso financeiro não foi paralelo ao artístico, sendo mister recorrer a empréstimos bancários para sua manutenção, principalmente para fazer face aos gastos efetuados coma peça, cuja montagem [...] foi de um custo elevadíssimo. É necessário, porém, prosseguir naobra, preparar o presente para enfrentar o futuro sem esmoreciento e sem medo. ${ }^{243}$

\footnotetext{
${ }^{242}$ Segundo reportagem de Bruna Becherucci com Zampari na revista Anhembi de novembro de 1958; in: GUZIK, 1986, p. 171; Dionysos, 1980, p. 115

${ }^{243}$ FERREIRA, 1958, p. 6
} 
Além disso, no relatório Zampari pela primeira vez menciona de forma pública sua intenção de promover um evento de aniversário para a companhia, com a programação de um Congresso de Teatro em outubro, mês de aniversário do teatro, e três peças a serem realizadas: "Macbeth", o clássico de Shakespeare, autor que seria encenado no TBC pela primeira vez; "Panorama Visto da Ponte", de Arthur Miller que na primeira versão de tradução mencionada no relatório se chamaria "Ao Pé da Ponte do Brooklin” - e “(...) uma peça nacional a escolher-se que esteja no nível das precendentes". Sobre esta, na edição de maio da Anhembi foi revelada que a peça seria "Pedreira das Almas", de Jorge Andrade, “(...) pelo simbolismo de que se reveste: a formação da grei paulista exatamente no momento de sua transição do período de mineração para o período agrícola do café" 244 .

Com o processo passando pela Comissão de Cultura ao final de março de 1958, a tramitação para concessão no mesmo ano se tornaria um verdadeiro desafio para um orçamento federal estrangulado pelas obras em Brasília. Ademais, o motivo para que o primeiro projeto tivesse sido apresentado na Câmara de São Paulo ainda em 1957 foi para que, uma vez que fosse aprovado, estivesse garantido no orçamento posterior. $\mathrm{Na}$ Câmara dos Deputados, apesar da tramitação correr por mais instâncias, o projeto não precisou ir ao plenário. Depois da Comissão de Cultura, foi à de Finanças pela dúvida sobre a liberação de verbas no ano corrente, sendo de lá mandada direto para o Senado.

Como a liberação do processo para o Senado se deu apenas em dezembro de 1958, o pedido chegou sem tempo hábil para que pudesse ter entrado em discussão para os fins do aniversário da companhia. Desse modo, a tramitação seguiu como uma lei "transformada em norma jurídica", termo usado para dizer que o pedido, apesar de ter entrado em discussão fora do prazo inicial, seria considerado no processo legislativo em seu mérito como algo passível de ser vetado ou aprovado, e portanto se tornar lei ordinária $^{245}$. Então, em 11 de junho de 1959, houve a sanção do presidente Kubitschek para concessão do auxílio de três milhões de cruzeiros ao TBC, transformado em Lei N. 3566, através de crédito especial da dotação orçamentária do MEC.

\footnotetext{
244 Publicado no programa de aniversário do TBC, in: Dionysos, 1980, p. 113

${ }^{245}$ Cf. em: AQUINO, Leonardo Gomes de. Processo de elaboração legislativa de uma norma jurídica, in: site Estado de Direito, 04 de maio de 2017, Disponível em: <http://estadodedireito.com.br/processode-elaboracao-legislativa-de-uma-norma-juridica/> Acessado em 15 de agosto de 2019
} 
Junto à abertura na Câmara dos Deputados, abriu-se processo ${ }^{246}$ em outra instância do governo federal, o SNT, o qual oficialmente não havia dado amparo ao TBC durante toda a sua existência. O auxílio pedido fora dos editais anuais do órgão era baseado na mesma argumentação, onde se destacava a questão do amparo após os incêndios sofridos pelas sedes do TBC, e a continuidade da “(...) realização de espetáculos de "alta categoria" da companhia. Espetáculos esses que foram realizados em lembrança ao aniversário do TBC desde 8 de junho, com a estreia solene de "Panorama Visto da Ponte" - "Macbeth" acabou não sendo encenada -, protagonizada por Nathalia Thimberg e Leonardo Vilar, sob direção de D'Aversa. O TBC com isso se encheu novamente de júbilo pela pompa e qualidade expressos por todos os envolvidos.

De outras entidades, Franco Zampari recebeu reconhecimento da Associação Paulista dos Críticos Teatrais (APCT, atual APCA) ${ }^{247}$ e Sindicato dos Jornalistas pelos dez anos do TBC, e como continuidade dos afagos dos órgãos oficiais, ele ainda compareceu a uma sessão da Câmara Municipal de São Paulo em 11 de novembro para receber uma homenagem na forma de um título de cidadão paulistano. Seu discurso, muitas vezes reproduzido, é pujante em sua declaração de amor à cidade:

Nasci em Nápoles, no dia 10 de setembro de 1896. Cheguei ao Brasil em dezembro de 1922. Já vim formado, trabalhando como engenheiro mecânico e industrial desde aquela época. [...] Senti que, tendo recebido tudo em São Paulo, precisava devolver alguma coisa à cidade. Sendo um parque industrial de primeiríssima ordem, centro agrícola, com um movimento de renovação literária que se afirmava com os grupos ligados a Paulo Prado e à grande figura de Mário de Andrade, São Paulo não tinha ainda teatro. Daí a minha ideia de criar o TBC. ${ }^{248}$

Após a cerimônia, estreou em 20 de novembro "Pedreira das Almas", quebrando o recorde de encenação com mais pessoas no palco na carreira profissional do TBC com trinta e cinco artistas, sendo considerado o ponto culminante das festividades pelo teatro. É a entrada do TBC no gênero da exaltação da brasilidade profunda, a partir de um autor egresso das fileiras da EAD, escola a qual começou a freqüentar em 1951.

\footnotetext{
${ }^{246}$ Processo no 124.122/58, in: CAMARGO, 2017, p. 176

${ }^{247}$ A APCT foi fundada como Associação Brasileira dos Críticos Teatrais (ABCT), sendo transformada em "Paulista" em 1956 por Nicanor de Miranda, e reestruturada na Associação Paulista dos Críticos de Arte (APCA) em 1972 para abarcar outras expressões artísticas. Cf. em: CUNHA, Aguinaldo. APCA 60 Anos. São Paulo: Monolito, 2017

${ }^{248}$ MAGALDI; VARGAS, 2001, p. 222; Dionysos, 1980, p. 114
} 
Seria a celebração perfeita para mostrar o início e o fim do processo de formação buscado pelos empreendedores da SBC, em uma chave de sucesso e missão cumprida. Contudo, a peça não alcança o ápice buscado, tendo seu tom algo formal causado distanciamento tanto da crítica quando do público, com sete mil pessoas em quarenta e duas sessões, fazendo o teatro voltar à sua média de ocupação de 50\%. Nesse sentido, é "Panorama..." que acaba sendo a peça que verdadeiramente dá tom à celebração do TBC, por ter feito uma carreira completa na Bela Vista comperto de quarenta mil espectadores em cento e quarenta sessões, com $80 \%$ de ocupação média de público pagante. Um grande sucesso, que segue por mais de dois anos pelo Rio, interior de São Paulo, outras cidades do país e novamente na capital, contando no total com cento e quatro mil espectadores.

O ano de 1958 termina então com manifestações menos felizes que as habituais para um período de celebração, considerando-se para isso infortúnios acontecidos no período. Em 12 de dezembro, durante a temporada de "Pedreira das Almas", a SBC em reunião pediu a interrupção das sessões em uma semana por causa do afastamento repentino de Zampari, por força de um espasmo cerebral. Essa interrupção serviria para a associação traçar novos planos para o teatro após o pleno reestabelecimento de Zampari. $\mathrm{O}$ impasse sobre o que fazer a respeito ficou mais forte em meio à tensão das duas horas de reunião ${ }^{249}$. Decidiu-se por fim que os ensaios da nova versão de "O Anjo de Pedra", de Tennessee Williams, tambem seriam parados enquanto se manteria a peça "Rua São Luiz..." em cartaz no Rio. Em reunião aberta de representantes da SBC com outras pessoas da cena teatral e da sociedade, realizada na casa de Júlio de Mesquita Filho no dia seguinte, a decisão sobre a interrupção de "Pedreira..." acaba desfeita, mas as outras resoluções seguem de pé enquanto novas são tomadas.

Decidiu-se também por uma espécie de "intervenção branca" na direção da SBC na ausência de Zampari, em movimento de certa forma radical para o modo de organização da Sociedade. Antonio de Queiroz Matoso, sócio integrante da SBC, assume a direção geral e Alfredo Mesquita é alçado à direção artística, graças ao afastamento unilateral de D'Aversa sacramentado na mesma reunião. Essa nova diretoria solicitou antes do fim de 1958 um auxílio ao Governo do Estado de São Paulo,

${ }^{249}$ MAGALDI; VARGAS, 2001, p. 221 
única instância pública não contatada por Zampari durante o ano de 1958 em ocasião da celebração de dez anos do teatro. Como resposta ao pedido de auxílio, em 21 de dezembro o governador Jânio Quadros autorizou que, pela primeira vez, o TBC abrisse crédito para tomar empréstimo no valor de dez milhões de cruzeiros pela Caixa Econômica Estadual (depois Nossa Caixa), através do Plano de Concessão de Empréstimos às Empresas Teatrais lançado por ele junto à CET.

Com isso, Quadros reconhecia a utilidade pública da entidade, o que lhe garantia maior proteção patrimonial e facilidades na negociação de pagamentos. Esse seria o único meio encontrado pelo TBC para entrar em 1959 garantindo capital para continuar suas montagens, pagar credores e contratados, e tambem administrar investimentos. $\mathrm{O}$ TBC ganhava um ano de sobrevida em meio à sua crise. Porém, um grande baque acaba por minar as forças daqueles que buscavam reerguer o teatro. No início de 1959, o presidente da SBC Paulo Assumpção faleceu, comovendo a todos da Sociedade. Ele foi considerado o grande responsável pela costura política do acordo que culminou no empréstimo concedido pelo Governo do Estado. Ata de reunião da SBC realizada em 16 de março, com Zampari retornando à direção em reunião conduzida pelo presidente de honra Ciccillo Matarazzo, registrou a homenagem de Zampari a Paulo, tratando de seu trabalho junto ao TBC:

Com a palavra, o sr. Franco Zampari, em nome dos presentes, prestou comovente homenagem ao grande companheiro Paulo Álvaro Assumpção, recentemente falecido, ressaltando especialmente, dentre as beneméritas atividades que exerceu em sua proficua vida, as dedicadas ao TBC, as quais se caracterizam (pelo) cargo que soube conduzir com a maior dignidade, inteligência e honrades (sic) até o último dia de sua existência. Relembrou, outrossim, a maneira sábia e objetiva com que enfrentou as atuais dificuldades materiais da Sociedade, devendo-se à sua incansável dedicação os resulados alcançados junto aos amigos e ao Governo do Estado, que culminaram por reconhecer a Sociedade (como de) utilidade pública, através de competente decreto. ${ }^{250}$

Artisticamente, 1959 começou com outros artistas importantes do TBC montando companhia própria, como foi o caso de Fernanda Montenegro, que deixou São Paulo logo no início do ano para integrar o Teatro dos Sete no Rio, sob direção de Gianni Ratto. $\mathrm{O}$ ano seguiu ruim com problemas sérios nas montagens dirigidas por

${ }^{250}$ Ata acessada no Arquivo Gouvêa-Vaneau 
Alfredo Mesquita e Alberto D'Aversa, este reconduzido como diretor após a volta de Zampari de sua licença médica. "A Senhoria", de Jacques Audiberti, é dirigida por Mesquita com recém-formados da EAD, mas fica apenas duas semanas em cartaz após menos de mil pessoas assistirem suas sessões, evidenciando um total insucesso. D'Aversa enfrentou questionamentos em uma de suas três peças no ano ("Patate", de Marcel Achard), onde chegou-se a usar uma pessoa para servir de ponto, algo abolido no teatro paulistano desde o início do TBC, por falta de ensaios com o ator protagonista Ambrósio Fregolente ${ }^{251}$, e onde metade dos três mil espectadores veio por convites, sem pagarem ingresso ${ }^{252}$.

Ainda que "Senhorita Júlia", de Strindberg e uma versão russa da história shakesperiana de Romeu e Julieta feita por Peter Ustinov em "Romanoff e Julieta" lhe tenham dado algum fôlego e mantido o prestígio de D'Aversa, sua situação com a SBC continuava delicada, ainda que Zampari ao reconduzí-lo garantiu que seu contrato de dois anos seria mantido até o fim. A indefinição cada vez mais aparente entre seguir as velhas fórmulas e tentar algo novo levou o TBC a alugar o espaço para o empresário carioca Aurimar Rocha trazer ao palco "Pedro Mico", peça de Antonio Callado que passou um tanto despercebida no repertório de estreia do TNC em 1956, mas que com a emergência do teatro brasileiro de cunho social em 1958 causou maior impacto com a história de um elemento subversivo dos morros cariocas. O TBC aceitou de bom grado a proposta por saber que a peça estava há sete meses em cartaz no Rio, o que dava a perspectiva de render boas bilheterias em São Paulo com uma boa promoção.

Essa promoção vem de forma indireta com a crítica de Décio de Almeida Prado $^{253}$, que a comparou com "Gimba”, peça de Gianfrancesco Guarnieri em cartaz naquele momento no Arena, sob direção de Flávio Rangel com o Teatro Popular de Arte. O crítico dava ressalva ao que considerava ser uma tendência dessa emergente teatralidade brasileira em parecer maniqueísta e excessivamente reivindicatória por

\footnotetext{
${ }^{251}$ Fregolente começou tarde a carreira de ator, com 33 anos, no fim dos anos 1940. Atuou na primeira metade dos anos 1950 como apoio em peças no Teatro Cultura Artística, e na Companhia de Comédias Aimée quando vinham a São Paulo. Depois de papéis tambem coadjuvantes com Vaneau e Ratto no TBC, somente com D'Aversa ele teve chance como protagonista. In: FREGOLENTE, Ambrosio. Enciclopedia Itaú Cultural. 2019. Disponível em <http://enciclopediaitaucultural.org.br/pessoa16196/ambrosiofregolente> Acessado em 15 de agosto de 2019

${ }^{252}$ GUZIK, 1986, p. 176

253 Publicada em O Estado de S. Paulo em 22 de maio de 1959, republicada pelo Correio da Manhã no dia seguinte, in: GUZIK, 1986, p. 177
} 
justiça social e condescendência com tipos marginais. Porém, o que ele colocava sobre a protagonista como um defeito da peça, tambem poderia ser visto como um mérito dela, ao ressaltar que Antonio Callado colocou bom humor na figura de Pedro Mico, admitindo que a peça funciona como comédia e que essa era uma razão de seu impacto.

Sem qualquer intenção, essa peça que sequer era da programação corrente do TBC se tornaria marco dessa tendência que há muito ameaçava entrar dentro desse teatro ao mesmo tempo moderno e conservador, mas que parecia definitivamente se instalar nesse momento de profunda crise de identidade. Essa renovação deu oportunidade de ascensão a nomes como Flávio Rangel, que logo depois de ter seu trabalho reconhecido em "Gimba" assumia agora o protagonismo das montagens do TBC como diretor artístico.

Rangel começaria 1960 viajando com o elenco fixo do TBC por uma longa temporada por Porto Alegre de fevereiro a maio, onde sua primeira função era trazer uma versão considerada mais moderna, enxuta e de comunicação mais direta ao público para a peça "Leonor de Mendonça", de Gonçalves Dias ${ }^{254}$. O motivo oficial para a saída do elenco era uma reforma interna programada para ser feita em seis semanasa partir de fevereiro, onde se retirariam as colunas internas e se aumentaria o teto sob o palco do teatro, sempre considerado baixo. Parecia um retiro para uma companhia que por algum tempo se sentiu á beira do fim pela crise financeira. A verdade é que a turnê de Porto Alegre, a acontecer no Teatro São Pedro, serviu aos mesmos motivos que o empréstimo tomado entre o fim de 1958 e o início de 1959. Era preciso saldar dívidas, pagar novos e velhos contratados, e dar guarida ao elenco que ficou em São Paulo para ensaiar o projeto de Flávio Rangel para o palco da Bela Vista.

A turnê, que segundo Zampari poderia ir de Porto Alegre até Montevidéu e Buenos Aires - viagem esta que não aconteceu, pelo fato de não se conseguir programar nenhum teatro disponível, no que seria a primeira saída internacional da companhia do TBC -, tambem serviu para pagar as dívidas com o elenco que estava no Rio de Janeiro. Com os débitos saldados, em maio de 1960 a SBC decidiu por encerrar em definitivo as atividades de sua filial.

254 Segundo reportagem de Fernando Peixoto para o jornal Correio do Povo, as outras peças do programa, dirigidas por D’Aversa, eram "Panorama Visto da Ponte" e "O Anjo de Pedra", em versão onde Nathalia Thimberg substituiu Cacilda Becker, in: Dionysos, 1980, p.61; 117 
Àquela altura, o TBC, além da reforma e da turnê, tinha outro aluguel a pagar na volta a São Paulo para acomodar "O Anjo de Pedra" no Teatro Maria Della Costa, sem atrapalhar o final da preparação da nova peça de Flávio Rangel. Pode-se dizer que a espera valeu a pena. "O Pagador de Promessas", do dramaturgo Dias Gomes, causou após sua estreia em julho de 1960 uma impressão inédita a respeito de um texto brasileiro, da mesma forma como o faria em sua adaptação para o cinema dois anos depois. Não apenas por ter sido o primeiro texto de autor nacional dirigido por um brasileiro no TBC, dentre outros dezoito textos anteriormente encenados no teatro. Também por isso, o caráter de identificação acabou talvez funcionando para o público que a assistiu, além da própria história que consegue abarcar temas universais em um microcosmo que pareceria, para quem o visse por um olhar folclorizado e estereotipado, por demais específico e localizado.

A peça acabou encenada pelo resto do segundo semestre de 1960, tendo realizado cento e trinta e nove sessões para vinte e quatro mil espectadores - ou seja, mesmo com uma aparente unanimidade, a peça se manteve na média histórica dos $50 \%$ de ocupação. Essa conta de espectadores para uma peça tão bem falada traz à tona questões colocadas por Zampari quando de seu balanço no ano do décimo aniversário da companhia. Uma delas é a questão do público, pois na ocasião Zampari comentava ser “(...) desagradável verificar que numa cidade de (na época) três milhões e quinhentos mil habitantes, o público dos bons teatros (era) limitado a um número entre quarenta e setenta mil pessoas",255.

Ademais, com o fato de que haveria muitas outras diversões de massa mesmo naquela época, com o teatro disputando espaço com o cinema, o futebol e a televisão, o comentário de Zampari também ilustra uma contraposição que separa os chamados "bons teatros", como ele diz, dos teatros de entretenimento, sendo que para as políticas de apoio ao teatro tal distinção não existiria ao ponto de uma ou outra vertente ser mais prestigiada. Ou se existisse, era em prol da que atraía maior atenção do público ${ }^{256}$. Para ilustrar isso, é mister considerar as estratégias usadas para atração e busca por fidelidade

\footnotetext{
${ }^{255}$ Dionysos, 1980 , p. 117

${ }^{256}$ Editais do SNT para concessão de auxílio a grupos teatrais no ano de 1958 mostravam uma tendência de mudança no foco do apoio estatal, pois no Conselho Consultivo, “(...) se em um primeiro momento, (...) muitos deles vinculados às companhias de comédia cariocas, privilegiavam itens ligados à "tradição", depois com a inclusão de novos membros - especialmente de figuras engajadas em um "projeto moderno" -, os valores estéticos assumiam maior importância, o que acirrou as disputas, incluindo pela própria direção do órgão" (CAMARGO, 2017, p. 175).
} 
de determinado público que busca ser atingido. Além disso, companhias ditas de teatro de entretenimento realizavam ações que poderiam ser também adotadas por companhias profissionais de teatro dramático, mas estas últimas as faziam com bem menos frequência e com maior pudor para que elas redundassem em maior apoio público.

Dentre companhias que receberam verbas do SNT para montarem temporada, havia exemplos de ações que buscavam sessões com preços populares, distribuição gratuita de ingressos para estudantes e realização de matinês culturais para professores $^{257}$. Desse modo, mesmo que houvesse pareceristas ou investidores a considerarem um gênero mais bem elaborado que outro, as diferentes estratégias de captação e retenção desse público pesavam na hora da concessão dos auxílios.

Outra questão para a qual certamente não se poderá dar uma resposta definitiva é em relação à continuidade do déficit no $\mathrm{TBC}$, visto que esses auxílios externos estariam aumentando nesse momento em que a companhia passava por uma fase de transição. Ao final de 1959, por exemplo, Zampari anunciou que o déficit total do teatro era de dezenove milhões de cruzeiros. No relatório enviado à Câmara dos Deputados, o único déficit informado por Zampari havia sido em 1952, segundo ano da companhia profissional, com saldo negativo de seiscentos e quarenta e um mil e trezentos e noventa e dois cruzeiros, um aumento de trinta vezes na dívida total em sete anos.

Disso depreende-se que, considerando todas as despesas e receitas colocadas pelo teatro até aqui, o rol de despesas com aluguel do teatro; direitos autorais; dívidas da reforma para transformação do prédio em teatro; salário de contratados fixos e eventuais; e manutenção de equipamento, devesse ser realmente muito maior que as receitas não apenas em sua variedade mas também no próprio montante acumulado. Por anos, falava-se na receita de bilheteria como a fonte principal de receitas, quando não garantidora de toda a estrutura mesmo com seu caráter naturalmente oscilante, e isso parece não ter mudado em tantos anos de atividade. Mesmo o valor pago pelos assinantes não sendo grande acréscimo pelo fato dos preços não serem diferenciados, a estratégia de fidelização também era falha, pois houve apenas duas grandes chamadas a respeito, logo que o teatro se tornou profissional e para manter o espaço do Rio pouco antes dele se incendiar.

${ }^{257}$ Exemplo da Companhia Dulcina-Odilon, para edital do SNT em 1943. In: CAMARGO, 2017, p. 176 
Rendas mais garantidas, caso dos sócios da SBC, pareciam ter sido esgotadas ou pelo menos cortadas em seu fornecimento, mesmo porque nem os gastos cobertos por eles, nem as contribuições dadas, eram totalmente publicizados, pois o TBC não era uma empresa de capital aberto como as dos contribuintes da SBC donos de indústrias e negócios próprios para deixar seus balanços publicados no jornal. Nesse cenário, todo o investimento público que passava a entrar no caixa da Sociedade pareceria como entrar em um buraco sem fundo, visto as últimas tentativas internas de tomada das rédeas do empreendimento para tentar dar novos direcionamentos à empreitada, por virem talvez que o modelo de gestão precisaria ser repensado devido à má administração dos recursos, em um mundo que mudava enquanto o TBC resistia a encarar essas mudanças.

O contexto em que se entra no ano de 1961 era então absolutamente feito para se chegar a um cenário de tempestade perfeita. Primeiro, houve convite informal de Flávio Rangel para Gianfrancesco Guarnieri montar no TBC novo texto seu, "A Semente". Esse convite teria partido quando da montagem de "Gimba" na Europa, com Flávio Rangel já tendo sido chamado a assumir a direção do TBC. Para Flávio, ter o trabalho de Guarnieri no palco que agora dirigia seria um bom complemento ao seu "Pagador de Promessas", assim como “(...) ter uma peça que fala de comunismo no templo do teatro burguês era de uma ousadia sem precedentes" ${ }^{\text {"258 }}$.

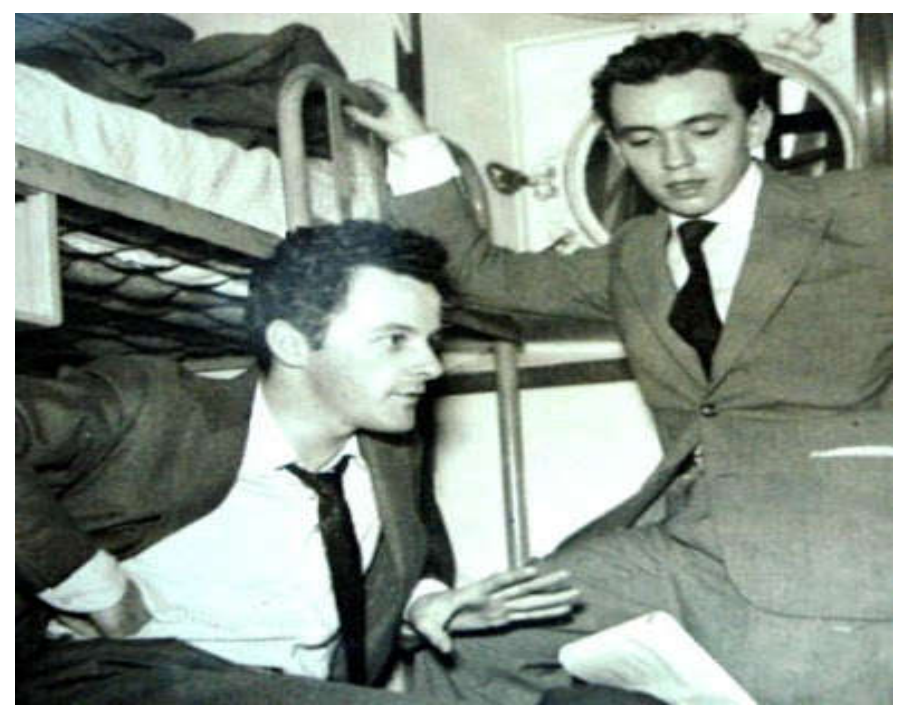

Imagem 22 - Flávio Rangel e Gianfrancesco Guarnieri em viagem para a montagem de "Gimba" na Europa (SCHMIDT, 2010)

258 SCHMIDT, Bernardo. "A Semente", in: blog 0 Patativa. 04 de fevereiro de 2010. Disponível em <http://bernardoschmidt.blogspot.com/2010/02/semente-de-guarnieri.html?m=1> Acessado em 15 de agosto de 2019 
Porém, após decorridos três meses de trabalho de ensaios, Zampari em nota publicada no jornal $O$ Estado de S. Paulo de 22 de fevereiro se declara impedido de honrar tais compromissos com o grupo. A nota de Zampari, curta e direta, foi escrita tal como se tivesse sido feito um pedido público de concordata ou recuperação judicial de uma empresa de outro ramo qualquer, e completa o seu tom trágico ameaçando também fechar o teatro, ao mesmo tempo que se dirige às autoridades e pessoas a quem dizia que seriam os únicos que poderiam salvá-lo:

A Sociedade Brasileira de Comédia, entidade sem fins lucrativos, declarada de utilidade pública pelo Governo do Estado de São Paulo, titular do Teatro Brasileiro de Comédia, vem a público para lamentavelmente informar à culta população de São Paulo que, face à impossibilidade de cumprir, no devido tempo, os seus encargos, vê-se obrigada a não prosseguir em suas atividades artísticas, o que se daria através da encenação da peça "A semente", de Gianfrancesco Guarnieri. Num Estado como o de São Paulo, que cada vez mais se caracteriza pela sua pujança econômica e riqueza material, dirigi-se um apelo ao governador, à Comissão Estadual de Teatro, à classe teatral e aos intelectuais, para que não deixem perecer, de maneira tão melancólica, a obra que foi a "celula mater" de todo o movimento artístico que floresce no país.

Seguem-se a isso embates entre a SBC e o Ministério do Trabalho por conta das reclamações por falta de pagamento aos envolvidos na montagem de "A Semente". Mais uma vez, uma comoção toma conta de artistas e autoridades que não queriam pensar na possibilidade de virem o TBC encerrar suas atividades, também por se considerar as possíveis consequências que seu fechamento teria às demais companhias profissionais.

Com isso, surge a União Paulista da Classe Teatral (UPCT), a partir de uma reivindicação de Nydia Lícia, então separada de Sergio Cardoso e ameaçada de perder o Teatro Bela Vista pelo fim da sociedade que mantinha a companhia montada junto a ele. $\mathrm{Na}$ época, o teatro estava alugado à Cia. Tônia-Celi-Autran e sua questão com a empresa que alegava ser a detentora do prédio do teatro, com a Justiça dando ganho de causa a Lícia, levou a uma união até então inédita entre os artistas. Nesse clima de maior engajamento e urgência que desde o começo visava a uma interlocução com o poder público - daí ter em sua composição, além dos cargos administrativos, um “conselho de reivindicações" -, assim a primeira diretoria da UPCT foi então formada: 


\begin{tabular}{|l|l|}
\hline \multicolumn{2}{|c|}{$\mathbf{1}^{\mathbf{a}}$ DIRETORIA - UPCT - 1961 } \\
\hline \multicolumn{2}{|c|}{ Presidente: Cacilda Becker } \\
\hline Vice-presidente: Roberto Freire & $2^{\circ}$ Vice-presidente: Cleyde Yáconis \\
\hline Secretário: Gianfrancesco Guarnieri & $2^{\circ}$ Secretário: Mauro Mendonça \\
\hline Tesoureiro: Nagib Elchmer & $2^{\circ}$ Tesoureiro: Armando Paschoal \\
\hline Diretor cultural: Flávio Rangel & Dir. de Propaganda: Líbero Rípoli Filho \\
\hline Conselho Fiscal: Moracy do Val & Conselho de Reivindicações: \\
Milton Gonçalves & Xandó Batista \\
José Puppi & Nathalia Thimberg \\
Sergio Marques & Luís Vergueiro \\
\hline
\end{tabular}

Fonte: MAGALDI; VARGAS (2000), GUZIK (1986)

Essa entidade, que buscava representar integrantes da cena teatral profissional na época, teve sua eleição marcada pelas reivindicações em torno da manutenção dos teatros, fortalecendo uma interlocução com a CET para fazer um enfrentamento mais forte a essas questões. A junção entre as duas entidades, a associação da cena teatral e o órgão governamental, pode ser considerada o embrião de uma ação estatal mais efetiva com relação ao teatro. Pois apesar do poder público se dar por satisfeito pelo que historicamente concedia às artes desde algum tempo na forma de auxílios e subvenções, atitudes como essa mostravam que, para além de assistência, era preciso construir uma política duradoura e abrangente para que não fossem poucos os beneficiados, mas toda a coletividade envolvida no fazer artístico.

Essa força da coletividade se mostrou em dois movimentos simultâneos em $1^{\circ}$ de março, quando o elenco que preparava "A Semente" permaneceu em ocupação dentro do TBC, enquanto a UPCT ia ao gabinete do governador Carvalho Pinto, à época no bairro central dos Campos Elíseos. As reivindicações eram bastante objetivas em relação à situação do $\mathrm{TBC}$ e dos artistas do teatro em geral. Para os artistas, os pedidos giravam em torno de trinta milhões de cruzeiros para o orçamento da CET para que esta destinasse os recursos às companhias segundo suas necessidades. $\mathrm{O}$ acordo final com os representantes da UPCT acabou ficando em vinte milhões de cruzeiros, a serem garantidos em projeto de lei enviado à Assembleia Legislativa para aprovação imediata.

Quanto ao TBC, o Governo do Estado se posicionou concedendo ao teatro novos empréstimos junto ao BANESPA com diferentes e específicas destinações. O primeiro seria de três milhões de cruzeiros para manutenção das atividades do TBC, e o outro seria da ordem de cinco milhões de cruzeiros, para terminar de pagar as dívidas do teatro, incluindo as questões trabalhistas do grupo que agora ocupava seu interior. 


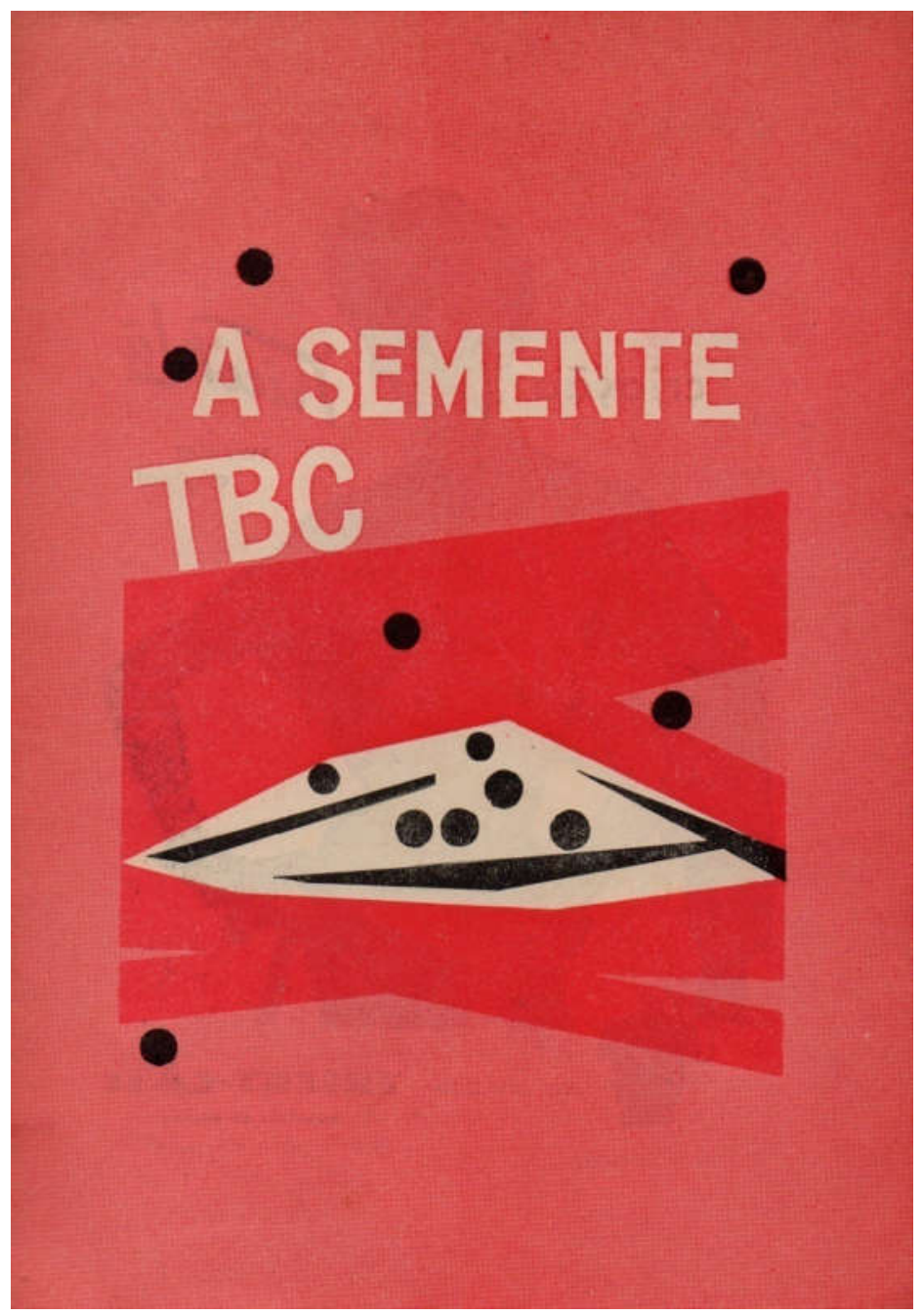

Imagem 23 - Capa do programa da peça “A Semente”. Fonte: CEDOC/FUNARTE

Essa resolução fez com que se decretasse intervenção do poder público no teatro, como condição para que os empréstimos fossem aprovados imediatamente, ao passo que a SBC teria poder de decisão a respeito dos próximos passos. Tão ruim quanto o cenário de indefinição seria uma recepção negativa para os próprios planos. Isso acaba se passando em relação à maneira como esse acordo dos novos empréstimos do Governo do Estado ao TBC foram recebidos pela diretoria da SBC, ainda que não houvesse muito o que questionar face à situação delicada da empresa.

Em reunião no dia 15 de março, a SBC fechou questão em relação ao nome de Ricardo Freire como novo diretor-superintendente indicado pela CET para administrar o teatro pelos próximos dois anos, enquanto seguia recebendo doações de entidades privadas como o Jockey Clube de São Paulo, que ao final de fevereiro havia colocado a quantia de três milhões e quatrocentos e sessenta mil cruzeiros à disposição da SBC. 
Esses empréstimos e doações foram levando a SBC a deixar de ter total autonomia na administração do teatro, pois a rolagem de tais fundos, ao invés de permitir a continuidade das atividades de forma plena, engessava a todos por se pensar no que poderia acontecer caso eles não estivessem disponíveis no futuro. A própria ata da reunião de 15 de março frisava isso ao dar “(...) uma moção de confiança ao governador no sentido de que serenamente o TBC aguarda a efetivação imediata do apoio prometido à Sociedade e ao teatro paulista, ${ }^{, 259}$.

Porém, Zampari não parecia totalmente contrariado com essa solução. Em entrevista dada à revista Anhembi em outubro de 1961, ele chega a advogar uma “(...) ajuda real aos teatros estáveis de cada cidade (como) aplicado em quase todos os países europeus (...) por se considerar o teatro como elemento de cultura" (apud DIONYSOS, 1980, p.121) como solução para a constituição de uma política pública "necessária" à manutenção de todos os tipos de teatros. O problema de se incentivar esse tipo de política é que o TBC havia chegado a um ponto onde pedidos de ajuda ao governo se tornaram condição absoluta para sua continuidade.

Aparentemente, o TBC havia então adquirido certa estabilidade administrativa. Roberto Freire, na sua condição de diretor, convocou os sócios do teatro ao colocar em uma carta de forma sucinta todo o movimento acontecido para a manutenção das atividades do TBC, fazendo-os se tornaram partícipes do processo decisório da SBC em relação ao teatro e assim tendo por parte da nova direção uma motivação maior para seguirem contribuindo com a anuidade de três mil e quinhentos cruzeiros, preço do talão que dava direito a dez entradas para estreias e dez ingressos avulsos para qualquer espetáculo.

Esse esforço de proximidade do diretor Roberto Freire para com os contribuintes da SBC pareceu flagrante nos últimos parágrafos do comunicado, quando ele designou o nome do responsável pela manutenção desse contato direto cotidiano entre a diretoria da CET e os sócios da SBC, para dessa maneira mostrar seu compromisso pela continuidade do empreendimento:

\footnotetext{
${ }^{259}$ Ata acessada no Arquivo Gouvêa-Vaneau
} 
O Sr. Adolfo Martins Vizeu, nosso representante e cobrador, está credenciado a dar quaisquer informes a respeito da nova campanha de sócios, [...] reafirmando nossa intenção de trabalhar pelo bem do Teatro Brasileiro de Comédia, esperamos continuar a contar com a compreensão do prezado sócio, pelo que agradecemos e apresentamos nossas cordiais saudações. ${ }^{260}$

Antes do final do ano, foi feito para a SBC um balanço pelas mãos do Flávio Rangel que trazia um diagnóstico interessante para embasar a continuidade da aposta na dramaturgia brasileira, que para ele faria com que o TBC pudesse “(...) refletir em termos ambientais e sociológicos as contradições íntimas da realidade do nosso país" como se essa nova fase do TBC pudesse estar cada vez mais identificada com os conceitos de teatro que norteavam companhias como as do Teatro de Arena, do Oficina e do Teatro Popular da Arte.

Nesse sentido, colocar o conceito de grupo de teatro em contraposição ao conceito de companhia, que foi a questão que norteou o TBC desde seu início, deveria ser entendido de uma forma mais abrangente do que naquela época, apesar de que seu ideal de estímulo à criação coletiva era de algum modo semelhante. $\mathrm{O}$ trabalho coletivo, por mais inusitado que possa parecer, iniciou-se primeiro na seção administrativa, com o esforço feito por Maurício Klabin Segall como novo diretor-superintendente indicado pelo SNT entre maio e novembro de 1961. Segall fez questão de dividir responsabilidades de sua função com Flávio Rangel e Armando Paschoal, então diretor administrativo. Realmente, o documento com assinatura de Rangel com o balanço de 1961 e as perspectivas para o ano seguinte traz a marca de todos esses envolvidos.

Mas para ele o período foi "estimulante" por sentir que também os artistas que permaneciam na companhia estavam envolvidos em outras funções, com todos trabalhando na base de produção ${ }^{261}$. Isso para ele era o diferencial do teatro em relação a um trabalho de empresa, onde funções estão mais bem delimitadas, o que, por conseguinte, faz com que não se tenha ideia de todo o processo para a realização de um produto. Para ele, no teatro essa coletivização deveria ser encarada como inerente ao que ele representa:

\footnotetext{
${ }^{260}$ Ata acessada no Arquivo Gouvêa-Vaneau

${ }^{261}$ Segundo entrevista à revista Dionysos, 1980, p. 163
} 
Um trabalho coletivo não é comum em teatro (de hoje). Todos abdicando de sua especialização, e embarcando no empreendimento com o mesmo entusiasmo. [...] Fora o Arena, acho que não havia nenhuma outra experiência assim. ${ }^{262}$

Segall, apesar de vir de um contexto empresarial, advogava por um teatro subvencionado pelo Estado. Ele soube ponderar sobre as razões do que defendiam essa prática por fazer com que se trabalhasse sem preocupações com a bilheteria, e dos que a atacavam pela possibilidade de submissão a projetos de poder e de governo. O próprio Segall teria sido de certa forma vítima dessa dicotomia, pois alega-se que sua demissão da CET, e consequente saída da direção do TBC sob direção desta entidade, se deu por sua defesa do modelo subvencionado que o CET não queria estimular naquele momento.

Em relação aos desejos de independência em relação à bilheteria, o TBC seguia sofrendo com isso mesmo com toda a boa vontade em fazer com que seu caminho fosse diferente. A própria conclusão final do relatório assinado por Rangel para a SBC em 1961 não parece dar maiores perspectivas para se fugir disso a curto prazo, e ainda usa a questão do passivo e das amarras feitas por administrações anteriores para dizer que não haveria saída:

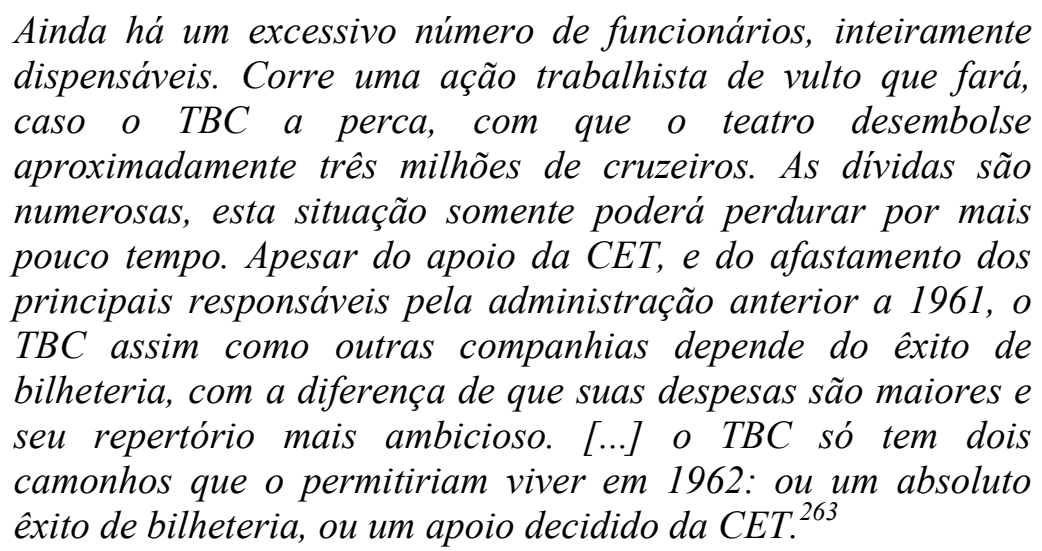

A questão dos pagamentos a funcionários atuais e antigos, incluindo artistas, era outro nó que não conseguia ser desatado. Primeiramente, o caso dos artistas "de valor" com salários inflacionados, exatamente pelo aumento cada vez maior no custo de vida, seguia sem que houvesse muito controle ou uma solução por parte da diretoria da CET.

\footnotetext{
${ }^{262}$ Segundo entrevista à revista Dionysos, 1980, p. 163

${ }^{263}$ Ata acessada no Arquivo Gouvêa-Vaneau
} 
No relatório de Rangel, fala-se muito na equiparação de salário de artistas com muito tempo na companhia e ainda não recebiam como artistas do tipo "A", como Zampari classificava. Era o caso de Cleyde Yáconis, que recebia então trinta e dois mil e duzentos cruzeiros e passou a ganhar o mesmo que Nathália Thimberg e Leonardo Vilar na sua renovação de contrato. O problema é que os problemas administrativos faziam com que o salário, e mesmo a permanência, de outros artistas não estivesse garantida. Por não se saber quem aceitaria a diferenciação nas categorias de salários, o futuro desses atores na companhia continuava dependente das questões externas. Os principais teriam aumento de $25 \%$ - com salários entre quarenta e seis, e trinta e cinco mil cruzeiros - enquanto os demais teriam $40 \%$ a mais no próximo ano - salários de vinte e um. a vinte e cinco mil, segundo estabelecido pelo Sindicato) ${ }^{264}$.

Mas a maior incerteza recaiu sobre o salário do diretor: Zampari havia estabelecido desde o início que os salários dos diretores estrangeiros seriam cotados em dólar (o último salário divulgado por ele foi o de Vaneau, de oitocentos dólares em $1956)^{265}$, e Rangel preferiu deixar frisado em seu relatório que a resolução dessa questão estaria exclusivamente com a CET e que ele acataria a solução dada por eles, por não querer polemizar a respeito disso com a SBC enquanto se concretizava solução para os demais impasses da companhia.

Mesmo com tudo isso, artisticamente era preciso fazer acontecer, mesmo com tantos percalços. A questão de "A Semente" sequer havia terminado com a resolução das questões trabalhistas. Houve contra a peça a mais forte perseguição da censura em relação a qualquer peça com a intenção de ser montada no TBC. Prevista para abril de 1961, com menos de um mês para a estreia a peça não havia tido parecer da Censura Federal, mesmo com a flexibilização nos critérios da censura em São Paulo quando da criação da CET.

\footnotetext{
${ }^{264}$ Os salários das categorias "menores" tiveram uma porcentagem maior em seu aumento salarial exatamente para chegarem ao nível exigido pelo Sindicato - no caso, o SATED.

${ }^{265}$ Em relatório onde publicou essa informação de Vaneau - "Causas Fundamentais e Secundárias da Crise Teatral em São Paulo e Particularmente do Teatro Brasileiro de Comédias" - na revista Anhembi de outubro de 1961, Zampari também diz em relação à sua gestão no TBC que chegou a não mais chamar "músicos especializados" para acompanhar as peças no final de sua gestão, numa atitude ironicamente igual à dos filodramáticos na primeira década do século XX para cortar suas despesas. As outras informações colocadas por Zampari no seu relatório estão contempladas em outros momentos no decorrer do texto. In: Dionysos, 1980, p.121-3; Cf. na p. 27
} 
Conversando com altas autoridades como o próprio presidente Jânio Quadros, um apoiador e frequentador do teatro nacional, Guarnieri e Rangel tiveram delas a promessa de que o caso chegaria direto ao gabinete do Secretário de Segurança paulista, Virgílio Lopes da Silva. O caso é que um assessor que substituía Virgílio Lopes bem no dia que o processo chegou à secretaria emitiu um parecer proibindo a peça dois dias antes de sua estréia, por “(...) alusões deprimentes às autoridades civis e religiosas usando linguagem do mais baixo calão", entre outras justificativas ${ }^{265}$. A resolução anterior da questão por parte das autoridades parecia algo tão incompreensível como tal proibição nas baixas instâncias, mas a explicação para a atitude do substituto é essencial para se compreender o funcionamento da síndrome de pequeno poder nele e em outros que tentam usar desse subterfúgio para causar constrangimentos a quem consideram merecer:

Guarnieri e Flávio foram até Virgílio e pediram a ele que tornasse sem efeito o parecer do substituto, com base no aval de Jânio. Virgílio, pisando em ovos, argumentou que não poderia simplesmente desautorizar uma ordem de seu substituto. Mas ofereceu uma solução: a peça seria apresentada para uma comissão de intelectuais formada por membros da imprensa, das artes, da edilidade, da igreja, do rabinato, etc. procedimento idêntico, aliás, a que foi submetida a peça "Boca de Ouro", de Nelson Rodrigues, no ano anterior - e a decisão dessa comissão seria pesada junto ao parecer da censura. $\mathrm{Na}$ madrugada de 26 para 27 de abril, o espetáculo foi encenado no TBC, para uma comissão que contava 7 pessoas. Terminada a apresentação, a comissão se reuniu naquela madrugada mesmo, e às 4 da manhã decidiu, por 5 votos a 2, pela liberação da peça. Mas, tal qual uma votação que envolve o Senado e a Câmara, a liberação dos intelectuais - que já continha alguns cortes mínimos que Guarna fizera de bom grado para apressar o processo - teve que ser, por sua vez, analisado pela censura. Para essa análise, foram nomeados três censores. E era sempre nesses "censores biônicos" que morava o perigo. ${ }^{266}$

Apesar da espera pela liberação posterior, o fato de o processo ter chegado às altas instâncias, e não reclamado por um autor sem tais contatos com essas autoridades e sem ser encenanda em um dos maiores teatros da cidade, acabou pesando para a liberação da peça, ainda que com a ressalva de esta ter sido liberada para encenação

\footnotetext{
${ }^{265}$ SCHMIDT, 2010

${ }^{266}$ Idem Ibidem
} 
apenas e tão somente para esta temporada no $\mathrm{TBC}^{267}$. O pequeno escândalo de sua liberação próximo à data de estreia fez com a peça ficasse com lotação máxima por quatro semanas, para depois sucumbir a uma campanha difamatória de setores da Igreja Católica, esvaziando suas sessões. Outra peça em 1961 que consegiu semelhante repercussão foi "A Escada", de Jorge Andrade. Na verdade, pode-se dizer que esta superou a de Guarnieri na aceitação popular - cento e sessenta apresentações para trinta e seis mil pessoas, com $63 \%$ de ocupação média. Assim, as peças nacionais conseguiram finalmente fazer por um breve momento voltar ao TBC a aura de influência sobre o teatro da cidade, ou ao menos deixá-lo emparelhado ao movimento em voga naquele momento.

Em 1962, aconteceram duas mudanças importantes. Uma delas era planejada, a chegada de Antunes Filho para compor o time de diretores da casa. O convite de Rangel a ele partiu pela valorização nacional experimentada pela casa e para lhe dar oportunidade de mostrar seu trabalho, pois Antunes Filho se encontrava afastado dos palcos há algum tempo. A segunda mudança foi um tanto inesperada, e se deveu a uma confusão administrativa. Armando Paschoal vinha experimentando atritos com a nova direção do teatro, citando a encenação em 1961 de "Almas Mortas”, de Gógol, feita entre as peças de Guarnieri e Jorge Andrade, segundo ele, contra a sua vontade por ter considerado a sua produção dispendiosa e de pouco apelo, o que se confirmou pelo fato dela ter ajudado a acabar com o crédito recebido dos empréstimos no início do ano ${ }^{268}$.

A gota d'agua para Paschoal foi um episódio em que Flávio Rangel teria liberado parte do elenco de "A Escada" para fazer uma peça alheia ao TBC, em Belo Horizonte, sem seu consentimento e em meio à temporada da peça que estava acontecendo no teatro, aproveitando-se de uma viagem de Maurício Segall à Europa. Flávio Rangel teria sido o único a saber do plano dos atores, tendo inclusive comunicado o público presente ao teatro no dia da saída deles de que a peça não aconteceria "por motivo de força maior". Armando Paschoal se sentiu desrespeitado

\footnotetext{
${ }^{267}$ Segundo o Arquivo Miroel Silveira, esse subterfúgio da Censura Federal de permitir a liberação de peças apenas para uma temporada e companhia específicas seria utilizado novamente com o TBC na temporada em 1962 de "A revolução dos beatos", de Dias Gomes, ainda com alguns cortes e classificação etária exclusiva para maiores de 18 anos. Também segundo o Arquivo, outra peça brasileira apresentada pelo TBC e que sofreu esta restrição mesmo com posterior liberação para montagem foi "Rua São Luiz, 27 - 8o andar", em 1957. No caso de duas peças estrangeiras - "Volpone", em 1955; e "Patate", em 1959 -, houve apenas cortes e classificação etária para maiores de 18 anos.

${ }^{268}$ Dionysos, 1980 , p. 149
} 
com essa atitude e assim entregou seu cargo. Mauricio Segall também deixou a direção ao saber do ocorrido, fazendo Décio de Almeida Prado assumir seu posto em 1962.

Em dicotomia semelhante a que Jacobbi via entre ele e Ziembinski, Antunes se colocava como diretor em seu próprio estilo absoluto, contrapondo-se a Rangel que estaria mais próximo ao encenador "condicionado" ${ }^{\text {269 }}$. Trabalhando desde o início da carreira com artistas mais jovens, sua nova fase no TBC serviu para trabalhar a presença de oriundos da EAD no palco profissional, com grande destaque para o modo de "(...) aproveitar sua técnica e habilidade especial no trato com os atores" ${ }^{\text {270 }}$. Sua primeira peça foi "Yerma", de Federico Garcia Lorca, que apesar de não ser brasileira, trouxe o lirismo que se tornaria uma das características mais marcantes na carreira do diretor. Ele mesmo o considera não apenas “(...) muito bonito, um dos melhores espetáculos (ondeteve magnífica crítica, deu pra se pagar, e se deu prejuízo foi muito pouco"271.

O final de 1962 reservaria mais um capítulo dramático nesse final aparentemente inevitável, e ainda assim adiado, do TBC: em 21 de outubro, diante de novamente não pagar suas dívidas, o TBC fecha suas portas mais uma vez. Isso leva os funcionários e artistas remanescentes, com Cleyde Yáconis à frente e Guilherme Vitale representando a CET como novo diretor-superintendente, a novamente apelar ao Governo do Estado, então o maior credor do teatro graças aos empréstimos concedidos em sequência. Em reunião com o governador Carvalho Pinto em janeiro de 1963, a primeira providência pedida seria a liberação de dois milhões e novecentos mil cruzeiros bloqueados pela Comissão de Orçamento do estado, graças a falta de pagamento dos empréstimos.

Junto a isso, pedia-se uma última carta de confiança do governandor no teatro, visto que ele estava para deixar o cargo. Um verdadeiro último suspiro para um teatro que se via agonizante e necessitado há tempos. Para isso, foi pedido para que, junto à liberação do dinheiro bloqueado, houvesse concessão de mais dez milhões de cruzeiros que seriam para pagar os outros credores e garantir as necessidades do TBC para produção de mais uma temporada. A garantia desse auxílio com sua assinatura ficou marcada como o último ato de Carvalho Pinto enquanto governador do estado ${ }^{272}$.

\footnotetext{
${ }^{269}$ Cf. na p. 101

270 SILVA, 1989, p. 113

${ }^{271}$ GUZIK, 1986, p. 209-10

272 MAGALDI; VARGAS, 2001, p. 242
} 
No início de 1963, houve nova tomada de fôlego do TBC com a recontratação de Maurice Vaneau, agora acumulando cargos de diretor geral e artístico, pela sua experiência anterior em lidar com questões administrativas ao substituir Zampari nessa função durante suas viagens. Em fevereiro, inicia-se uma campanha publicitária simples e ao mesmo tempo inovadora, com desenhos do próprio Vaneau distribuídos em cartazes pela cidade e anúncios de jornal promovendo sua nova encenação: "Os Ossos do Barão", de Jorge Andrade. Em grande estilo, essa campanha contou com frases espirituosas ligadas a situações cotidianas da classe média, em que o escape delas poderia ser feito com a ida ao teatro, conclamando as pessoas a comparecerem ao TBC e assistirem a esse momento que prometia ser especial a elas. Os cartazes continham frases como: "NÃO IMPORTA QUANTAS HORAS VOCE TERÁ QUE FAZER FILA PARA ENTRAR NA BALSA DO GUARUJÁ, PORQUE LOGO QUE CHEGUE A SÃO PAULO, PODERÁ ASSISTIR NO TBC A NOVA COMÉDIA DE JORGE ANDRADE, “OS OSSOS DO BARÃO”,".

Jorge Andrade, um dos autores mais encenados dessa fase do TBC, parecia mesmo um autor ideal para captar o momento em que se buscava essa maior identificação do público geral, não só com o TBC mas com a própria ideia de ir ao teatro, tal como no período de formação da companhia no fim dos anos 1940. O TBC finalmente havia começado a buscar textos que aproximavam palco e cotidiano, dialogando com a cidade junto a uma nítida predisposição das pessoas em frequentar o teatro como atividade cultural $^{273}$. Juca de Oliveira, um dos que mais esteve em peças nessa fase do TBC, publicou texto na revista Anhembi em $1962^{274}$ onde dizia que, apenas considerando-se os lugares não tradicionais onde houve apresentações teatrais no último ano pelo país, mais de cem mil pessoas haviam visto uma peça de teatro pela primeira vez, segundo ele três vezes mais do que o público médio no próprio TBC.

Foi nesse contexto que a campanha para trazer as pessoas para o TBC parecia fazer sentido para muita gente. Assim, junto á necessidade que o TBC tinha de se sustentar e pagar suas contas, era possível esperar alguma repercussão com o público. Para que houvesse um bom resultado nas finanças independente da frequência, os ingressos para a temporada de "Ossos..." custavam um preço jamais visto no TBC ou

\footnotetext{
${ }^{273}$ MARTINS ARANTES, 2001, p. 51
}

274 apud GUZIK, 1986, p. 206 
em qualquer outro teatro em São Paulo até então: mil cruzeiros para sessões no final de semana, e oitocentos cruzeiros durante a semana. Era temerário pensar se a peça poderia cativar o público geral, ou ao menos o público médio frequentador do teatro, em um cenário econômico de estabilidade no consumo médio na cidade, sem aumento de demanda e com rendimento salarial médio de mil setecentos e vinte e três cruzeiros. ${ }^{275}$

O elenco da peça tinha entre seus doze integrantes, mais cinco substitutos, alguns verdadeiros resistentes que passaram por várias fases do teatro, como Dina Lisboa e Cleyde Yáconis; atores experientes no cinema e televisão, como Otello Zeloni, Lélia Abramo e Mauricio Nabuco; e outros que eram considerados iniciantes mas que marcariam época, como Rubens de Falco e Aracy Balabanian. A cenografia considerada de "produção mais modesta"276 é de Marie-Claire, então recém casada com Vaneau e que o acompanharia em vários projetos. Junto ao programa, foi distribuído texto de Vaneau com tom questionador e reflexivo, mas conciliatório, sobre as possibilidades de futuro para o TBC e o teatro na cidade de São Paulo, conclamando apoio estatal e do público para sua manutenção:

\section{UM POVO TEM O TEATRO QUE MERECE}

O Teatro Brasileiro de Comédia foi criado em 1948 com a finalidade de dotar São Paulo de uma companhia teatral permanente estável.

Desde sua criação, porém, sua estabilidade não deixou de ser ameaçada. Em 21 de outubro de 1962, o TBC foi mais uma vez obrigado a fechar suas portas.

Apesar dos numerosos prêmios obtidos durantes os 2 anos de administração do TBC pela Comissão Estadual de Teatro, um só grande fracasso no ano que findou, bastou para que os alicerces deste empreendimento fossem abalados, chegando quase a desmoroná-los como a um simples castelo de cartas.

Hoje o TBC reabre suas portas, mas por quanto tempo?

É concebivel que um teatro que é responsável por todo o surto de renovação que empolgou o teatro brasileiro desde sua inauguração; que um teatro pelo qual passaram e até mesmo se formaram os mais importantes artistas das melhores companhias de teatro do pais; que um teatro que até hoje apresentou mais de 150 peças totalizando perto de 8000 representações, que um teatro que recebeu algumas dezenas de prêmios; é concebivel, pergunto que este teatro esteja à mercê de um ou dois fracassos de público?

\footnotetext{
${ }^{275}$ COLISTETE, 2009, p. 389
}

${ }^{276}$ GUZIK, 1986, p. 213 
Graças à compreensão, do espírito esclarecido do Governador Carvalho Pinto, concedendo uma verba extraordinária para as companhias de teatro estáveis de São Paulo; graças ainda a um auxílio que nos foi reservado pela última diretoria da Comissão Estadual de Teatro para a montagem, na próxima temporada, de duas peças de Jorge Andrade, o peso está consideravelmente aliviado. Porém, mesmo recebendo nossa parte - e não sabemos quando - nessas subvenções, ficaremos ainda diante de um rombo de vários milhões.

É esta a verdadeira paisagem, o lamentável panorama do teatro brasileiro em geral. É indispensável, é urgente reagir.

$E$ indispensável e urgente que os governos Federal e Estadual subvencionem seriamente o teatro de uma maneira eficiente $e$ contínua ou então, que as empresas particulares, as instituições filantrópicas tomem a si a responsabilidade de apoiar as manifestações teatrais. Mas é preciso mais ainda, é preciso que você, público, vá ao teatro, ame o teatro, propague o teatro, participando do desenvolvimento cultural de seu povo, com a mesma força, o mesmo dinamismo e a mesma audácia com que constrói pontes, estradas, fábricas e cidades. É seu dever de cidadão, como hoje também é o meu.

Eis porque, juntei-me a todos aqueles que desde a inauguração do TBC lutaram e continuam a lutar; eis porque juntei-me a todos esses homens e mulheres, muitos dos quais não recebem seus salários há oito meses, que confiam em nós, confiam em você. Foi a paciência deles (que) nos permitiu a montagem deste novo espetáculo.

Sim, é preciso gritar bem alto: se esta noite o TBC reabre suas portas para vos acolher, se foi possivel realizar este verdadeiro milagre, devemos isso unicamente à boa vontade, ao espírito de sacrificio, à tenacidade e obstinação destes "Saltimbancos": artistas, técnicos, artesãos.

Por isso em nome do TBC dedico-lhes este espetáculo. Os milagres, porém, não se repetem sob encomenda, mesmo no teatro. De vocês, depende o futuro.

Havia um clima de expectativa da administração do teatro a ponto de permitir uma concessão. A estréia em 8 de março de 1963 não teve ingressos vendidos por ter sido exclusiva aos sócios do Jockey Clube, seu então maior patrocinador privado. Porém, por mais incrível que possa parecer, o milagre esperado por Vaneau aconteceu novamente. O sucesso de público de "Ossos..." foi estrondoso, tornando-se de forma surpreendente a maior bilheteria de toda a história do TBC, com mais de cento e quatro mil espectadores no total, a ponto de ser a única peça encenada por todo o ano de $1963 \mathrm{e}$ ainda por alguns meses de 1964. 
Também houve uma lembrança especial para o espectador que comprou o ingresso de número 61.678 (vendido na vigésima nona semana da temporada), marcando a quebra do recorde anterior de "Casa de Chá do Luar de Agosto", também dirigida por Maurice Vaneau em 1955 $5^{277}$. A campanha com frases espirituosas e desenhos que lembravam propagandas e charges das revistas semanais continuou ativa nesses mesmos veículos por toda a temporada, mantendo a peça na boca do povo.

Pela análise da freqüência do público, é possível ver com ainda mais surpresa que a assistência não foi grande de imediato. Apenas na terceira semana em cartaz, o público passou a encher o teatro assiduamente. Nota-se tambem que, no início, havia uma posição refratária da administração quanto à distribuição de convites. Na segunda semana, esse número foi mais volumoso. E então a partir da quarta semana em diante, com a crítica tendo sido conquistada pela peça, o público praticamente todo se tornou pagante, mantendo-se da mesma maneira até quase sua última semana:

\begin{tabular}{|c|c|c|c|}
\hline \multicolumn{5}{|c|}{ PÚBLICO “OS OSSOS DO BARÃO” } \\
\hline Semana & Público Pagante (por Sessão) & Renda/Cr\$ & Convites \\
\hline $1^{\mathrm{a}}-9$ e $10 / 3 / 63$ & $608(152)$ & 530,2 mil & 7 \\
\hline $2^{\mathrm{a}}-12-17 / 3$ & $1361(221)$ & 1,07 milhão & 361 \\
\hline $3^{\mathrm{a}}-19-24 / 3$ & $2158(280)$ & 1,6 milhão & 38 \\
\hline $4^{\mathrm{a}}-26-31 / 3$ & $2731(351)$ & 1,95 milhão & 31 \\
\hline $5^{\mathrm{a}}-2-7 / 4$ & $2865(368)$ & 2,24 milhão & 44 \\
\hline $10^{\mathrm{a}}-7-12 / 5$ & $2485(323)$ & 1,95 milhão & 51 \\
\hline $20^{\mathrm{a}}-16-21 / 7$ & $2348(302)$ & 1,81 milhão & 25 \\
\hline $30^{\mathrm{a}}-24-29 / 9$ & $1740(226)$ & 1,27 milhão & 22 \\
\hline $39^{\mathrm{a} *}-26 / 11-1 / 12$ & $2877(367)$ & 1,23 milhão & 19 \\
\hline $50^{\mathrm{a}}-13-22 / 2 / 64$ & $1214(162)$ & 1,65 milhão & 37 \\
\hline $60^{\mathrm{a}}-12-17 / 3$ & $1319(175)$ & 2,18 milhão & 38 \\
\hline Total & $\mathbf{1 0 4 . 2 5 9 ( 2 3 6 )}$ & $\mathbf{9 5 , 1}$ milhão & $\mathbf{9 0 1 0} *$ \\
\hline
\end{tabular}

Fonte: Acervo Gouvêa-Vaneau

*a $40^{\text {a }}$ semana teve queda pelo início do período de festas, quando o teatro teve duas semanas de férias; a $39^{\text {a }}$ foi também a última semana com lotação completa do teatro **além dos mencionados convites da produção, 50 eram separados por semana à SBAT, totalizando 2790 convites extras durante a temporada

O começo de 1964, com o sucesso absoluto de "Ossos...", parecia promissor para o TBC, com os ensaios de uma nova peça sendo feitos em uma fazenda de Minas Gerais por Antunes Filho e seu elenco escolhido. "Vereda da Salvação" era mais um texto de Jorge Andrade, com enorme ambição estética no seu apuro técnico e produção, em um padrão exigido por Antunes para a montagem que acabou se tornando a verdadeira danação do teatro.

277 MAGALDI; VARGAS, 2001, p. 243 
Ensaiada em uma fazenda em Minas Gerais, contava com um elenco que misturava estrelas e jovens talentos entre seus vinte e três intérpretes, com nomes como Raul Cortez, Cleyde Yáconis, Aracy Balabanian, Sylvio Rocha, Lélia Abramo, Stênio Garcia, Ruth de Souza e Leilah Assunção. Porém, mesmo com a preparação isolada do turbilhão que tomou o país e culminou no golpe civil-militar de $1^{\circ}$ de abril, "Vereda..." acabou sofrendo algumas de suas conseqüências.

Por fim, a peça estreou apenas em julho de 1964, e acabou por desagradar a críticos de todas as correntes por seu tom considerado histérico, com a esquerda considerando a peça nostálgica e condescendente com a aristocracia, e a direita vendo nela uma crítica social descabida. O público também não embarcou na ambientação e na temática, resultando que a peça terminou sua temporada abruptamente em fracasso retumbante de audiência. A peça não durou um mês em cartaz, e causou decisões extremamente radicais por parte da $\mathrm{SBC}$, muito próximas as que Vaneau havia vaticinado que poderiam acontecer quando escreveu o texto introdutório à montagem de "Os Ossos do Barão".

O próprio Vaneau acabou sendo vítima indireta disso, não sem ao menos tomar algum proveito para si. Em reunião extraordinária da SBC em 17 de agosto de 1964, a diretoria decidiu então pelo desmantelamento completo da companhia a partir daquele momento, colocando o TBC á disposição de quem quisesse alugar o espaço para quaisquer tipos de apresentações, artísticas ou não. Nessa reunião, ainda foi oferecida a Vaneau por Guilherme Vitale, em nome da SBC, a continuidade de seu trabalho como diretor geral, no que Vaneau recusou por alegados "motivos pessoais".

A verdade é que Vaneau esperava esse tipo de comportamento, da parte dos administradores da Sociedade, para com a descontinuidade da companhia e considerava seguir um rumo próprio em uma produtora privada, que denominaria MVPA (Maurice Vaneau Produções Artísticas), constituída em sociedade com sua então esposa MarieClaire em novembro daquele ano. Ainda assim, na mesma reunião the foi dada oportunidade de continuar no TBC apenas na direção artística, sem a responsabilidade de gerir uma companhia, apenas cuidando das necessidades dos que eventualmente alugassem o espaço, no que Vaneau aceitou de bom grado. 
Com esse fim melancólico para o trabalho desenvolvido pela companhia fixa do TBC desde 1948, em sua luta pela afirmação do teatro brasileiro, é inegável pensar que houve muitos sucessos e insucessos, mas nunca se deixou de perseguir o melhor ao público daquele teatro. Para se pensar em como a situação chegou a esse final, é preciso lembrar o que aconteceu com aquele que foi o símbolo da construção daquela indústria de ilusões. Franco Zampari, no ano de 1964, parecia esquecido ao final dessa empreitada, recebendo apenas poucos amigos dentre os muitos que visitavam sua casa nos anos 1940 - entre eles a família Rheingantz.

Sua atuação e perdição como administrador do TBC foi resumida através dos detalhes colocados por sua mulher Débora, em entrevista concedida a Maria Rita Galvão (apud 1980, p.150-3) onde falou sobre os motivos que levaram Zampari a ter tamanha derrocada. Ela cita que a Vera Cruz teria sido a grande responsável pelo crescimento da dívida dele e da família, fazendo com que hipotecassem a velha casa dos encontros culturais dos grupos amadores na década de 1940, e tomassem empréstimos apenas para pagar dívidas. Considerando que da Vera Cruz também entrava dinheiro no TBC, pode-se pensar no quanto o caixa do teatro também ficou prejudicado.

O único patrimônio que ficou para Zampari e Débora foram os terrenos no Morumbi, valorizados pelo crescimento do bairro nos anos 1950, onde o lugar cheio de chácaras começava a ser ocupado por empreendimentos mais vistosos. Estes terrenos só não teriam também entrado nas vendas de Zampari, pois sua mulher era quem tinha o nome registrado nos títulos de compra deles, por ação anterior do próprio Zampari. Ambos só se lembraram da existência desses terremos quando já haviam perdido todo o resto do patrimônio.

E assim, o imigrante que buscava chegar ao nível dos grandes empresários da cultura, se viu tendo de amargar a inevitável queda. Como imagem definitiva da atuação de Franco Zampari e da maneira como buscou até quando lhe foi possível o que considerava o melhor para o seu teatro e para aqueles que confiaram em sua habilidade como homem de negócios, publica-se o anexo da ata da reunião que consolidou seu afastamento do TBC em 1961 para a CET assumir a direção do teatro. É uma mostra de que, mesmo tendo cometido erros humanos e administrativos em seu percurso, Zampari teve seu trabalho reconhecido e valorizado pelos que o sucederam: 
Novamente com a palavra, o Sr. Presidente (Franco Zampari) declarou que dessa forma passavam os destinos da Sociedade a serem regidos pelos Estatutos que acabavam de ser unanimemente aprovados. Continuando, disse mais o $\mathrm{Sr}$. Presidente que estavam sobre a mesa, cartas endereçadas à Sociedade por cada um dos membros da Diretoria, os quais elegantemente, a fim de facilitar ao trabalhos da presente assmbléia, punham seus cargos ao inteiro dispor da mesma, e solicitavam suas demissões.

Continuando com a palavra, o sr. Presidente declarava que face à situação financeira dramática da Sociedade, pedia que fosse expressamente consignado que exonerava a Sociedade de todas as dividas que tinha para com ele até aquele momento, e que nesse sentido, e que nesse sentido declarava, em vista daquela exoneração, nada mais ter a reclamar da Sociedade, seja a que título fosse.

Com a palavra, o sócio declarou que usava da palavra em nome de todos os sócios e agradecia mais este gesto nobre e desprendido do Sr. Presidente, que vinha a ser acrescentado à longa série de sacrifícios pessoais que o mesmo vinha fazendo no passado pela sobrevivência do teatro, e que em vista de tudo isso propunha um voto de louvor ao Sr. Franco Zampari, o que foi feito.

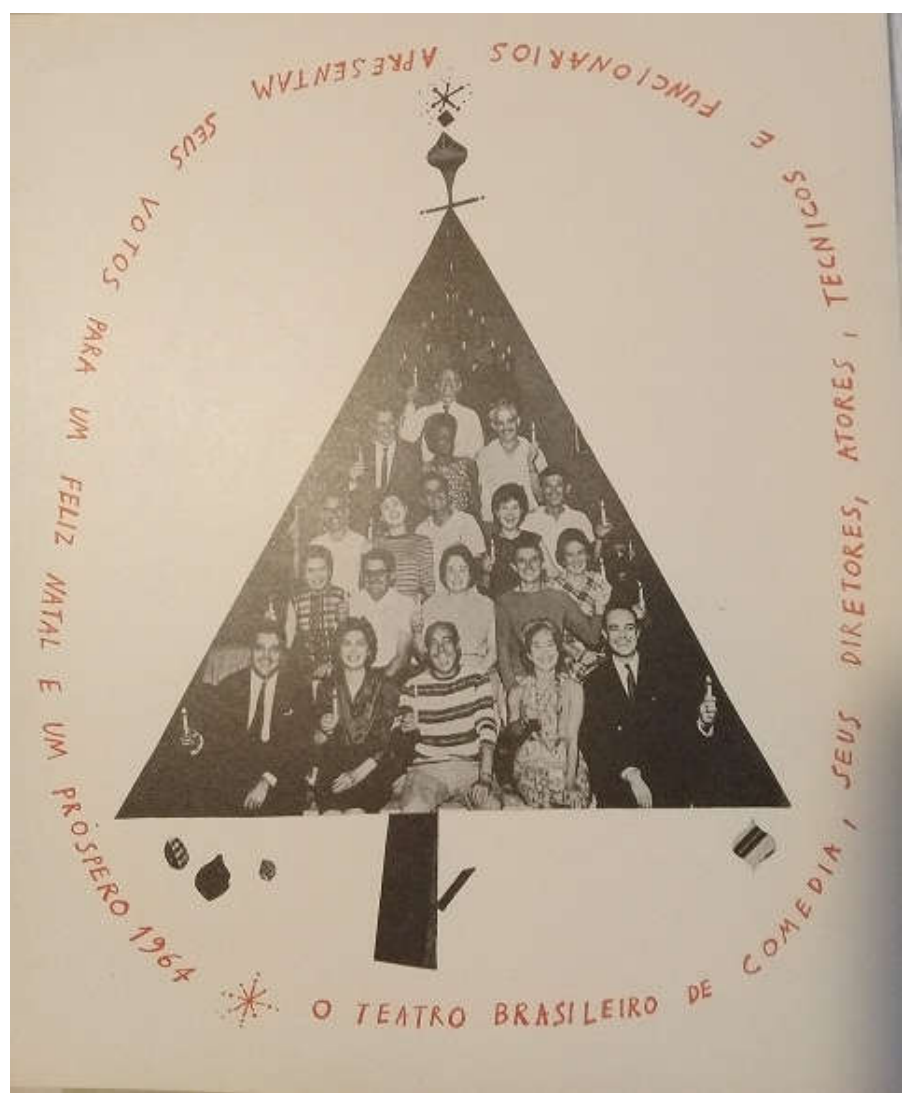

Imagem 25 - Cartão de Natal dos artistas e funcionários do TBC em 1963. (Acervo Gouvêa-Vaneau) 


\section{CAPÍTULO 3 : A ATBC e a situação dos grupos de teatro independentes na cidade de São Paulo}

\subsection{Evolução das Políticas para Grupos Teatrais Pós-1950}

No Brasil, é costume colocar como marco do início das políticas culturais a perspectiva do investimento privado, dos mecenas que "destemidamente" promovem cultura em meio a tantas carências e possibilidades do país. Considerando a história desde os tempos imperais, é possível ver, no entanto, que certos remendos de polítcas públicas sempre foram algo também a ser buscado como parâmetro, para que se desenvolvesse adequadamente essa promoção cultural. Quanto aos parâmetros que essas políticas tomaram no decorrer do tempo, eles se constroem e se modificam conforme os países cuja cultura se torna dominante quanto à exportação de seus conceitos de produção de pensamento e de modelos de vida.

Philippe Urfalino (2015) fala em seu estudo sobre a gênese das políticas culturais na França - país modelo da sociedade ilustrada brasileira até meados do século XX que uma sociedade onde a cultura é trabalhada como um processo de educação de seu povo se constitui em um lento processo de assimilação. Isso se daria porque, na sua natureza, uma ação cultural pode ser mais efetiva e imediata na formação de um indivíduo do que qualquer chamada progressão pedagógica. O que ocorre é que isso deve estar bem direcionado, de forma a atingir o máximo de pessoas, através da descentralização de ações e estratégias de alcance do público que em uma política de concentração das mesmas. Ou seja, quanto mais as pessoas forem expostas a ações culturais, de forma contínua e em diferentes lugares, experiências estéticas acumuladas poderiam então formar a cultura de um indivíduo.

E mesmo esse entendimento sobre o que seria uma política cultural democratizada e universalizante em seu acesso não apenas nunca foi unânime, com embates entre qual o valor dado à aprendizagem das práticas artísticas ou para a exibição de bens culturais, como só teria se dado dessa maneira na França com a criação do Ministério dos Assuntos Culturais. Fundado em 1959 com André Malraux como seu primeiro ministro, o ministério desde o início comportava designações estritas de suas funções específicas em relação às áreas com as quais se via correlata desde sempre, entre elas a educação. 
Sobre as razões que levariam a essa separação dos campos de atuação da escola, do Estado, e da cultura, Gaëtan Picon, então diretor geral do Departamento de Artes e Letras do novo ministério, traz uma definição bastante arguta a respeito:

Três domínios aparecem nitidamente (em que) se é tentado identificar essa noção de cultura: o do ensino escolar $e$ universitário; o do entretenimento, no qual vemos o Estado apoiar certos espetáculos ou dirigir o que chamamos de lazeres; o da criação artística, que é da alçada do indivíduo, mas no qual o Estado não deve deixar de intervir, seja que se contente (como nos regimes liberais) em honrar a criação livre, seja (como nos regimes totalitários) que tente controlar e dirigir seu jogo. ${ }^{278}$

No período da ascensão dessa discussão que vinham desde os anos 1940 na França, mas que finalmente havia emergido para instâncias de poder, o Brasil vivia com seu Ministério da Educação e Cultura correlatos à mesma pasta, e portanto ao mesmo método de aplicação de políticas estruturais para ambas as áreas. A política principal do Estado brasileiro ainda era a que Urfalino define como "Estado-mecenas", provendo subvenções com as quais patrocinava ações que considerava relevantes e de acordo aos interesses dos detentores do poder, em detrimento de uma política universalizante e democrática.

Era contra esse estado de coisas que se voltaram as companhias profissionais que surgiram desde o final dos anos 1940, e que moldaram a cultura teatral paulistana, e em certa medida de todo o país, durante os anos 1950. Elas tomaram para si as rédeas desse movimento a partir da emergência de uma formação mais universalizada com os grupos estudantis e escolas de teatro que, por extensão, ajudaram na constituição de um modelo próprio. Dentro da formação dessa estrutura, era natural que houvesse grupos mais próximos ou mais distantes de um modelo de manutenção puramente estatal, mesmo porque a estrutura oficial existente estava em constante transformação e consolidação. Com o tempo, algumas destas companhias e escolas acabaram se voltando para o próprio mecanismo que inicialmente rejeitavam, a ponto de todas elas em algum ponto de suas trajetórias terem recebido dinheiro público.

278 in: URFALINO, 2015, p. 37 
Isso se deu porque, enquanto pareciam estar seguindo modelos eurocêntricos de políticas culturais, esse modelo que vinha sendo construído na era moderna continha em seu interior um elemento local que acabou se perdendo com o tempo, pelo fato da maior consolidação e sistematização desse pensamento ter se dado em outros lugares. Um exemplo disso foi que, enquanto na França dos anos 1930 os primeiros modelos de separação entre a ação do poder público e do mercado privado sobre as artes parecia se desvirtuar do seu sentido original ${ }^{279}$, só chegando a um novo consenso quando da criação do Ministério dos Assuntos Culturais em 1959, a ideia de promover descentralização da cultura a partir da ação do poder público já se manifestava aqui quando da criação do Departamento Municipal de Cultura de São Paulo em 1935.

Rubens Borba de Moraes e Sergio Milliet, dois dos colaboradores na idealização do órgão ${ }^{280}$, publicaram em 1939 - após a saída de Mário de Andrade de sua direção um estudo pioneiro chamado "Consumo Cultural em São Paulo", onde vaticinavam a necessidade de um maior atendimento, quanto à oferta de bens culturais, em bairros limítrofes da cidade para nortear os conceitos que seriam levados adiante pelos que permaneceram após a saída de seu diretor. Os dois chegaram a ir à Europa, especialmente à França, apresentar os resultados de seus estudos, tamanha foi a repercussão e a exiqüidade das políticas propostas.

Porém, do mesmo modo como essa discussão começou, ela pareceu interrompida durante o Estado Novo, em que Vargas levava seu modo de governo autocrático para todas as áreas, inclusive a cultura. Com isso, uma maior centralização e burocratização da ação estatal fomentou essa nova visão de empreendimento cultural culminada na explosão de equipamentos culturais privados entre o fim dos anos 1940 e os anos 1950. Com as transformações na vida social do país - o advento da televisão, a mudança de hábitos da classe média, e a crescente demanda por democratização cultural -, um novo modo de produzir cultura precisava surgir.

\footnotetext{
${ }^{279}$ Cf. em URFALINO, 2015, p. 18-9

280 Segundo Abdanur (1992, p.53), Paulo Duarte (então chefe de gabinete do Prefeito) cita como freqüentadores de sua casa na Av. São João um grupo de "amigos, artistas, intelectuais e jornalistas (cujas reuniões) remonta à origem do Departamento, (entre eles) Mário de Andrade, Antonio de Alcântara Machado, Tácito de Almeida, Sergio Milliet, Antonio Carlos Couto de Barros, Henrique de Rocha Lima, Randolfo Homem de Mello e Rubens Borba de Moraes". In: ABDANUR, E.F. Dissertação de mestrado - Os "ilustrados" e a política cultural em São Paulo: O Departamento de Cultura na gestão Mario de Andrade (1935-1938). Campinas: IFCH/Unicamp, 1992, apud MANZONI, 2015, p. 24
} 
O que permitiu essa mudança na visão sobre a responsabilidade das ações do poder público e do poder econômico sobre a arte em geral, e o teatro em particular, foi a transformação na burguesia financiadora e dos executivos públicos quanto ao modelo cultural que buscavam implementar no país. O final da primeira metade do século XX testemunhou a consolidação dessa virada da França para os Estados Unidos como modelo de sociedade almejado pela elite ocidental. E, sem dúvida, não haveria lugar mais ambíguo para as confusões entre financiamento público e privado nas artes do que os Estados Unidos.

Dos anos 1930 até os anos 1960, a grande ação estatal para as artes nos Estados Unidos era o Federal Arts Project (Projeto Federal de Artes), criado por Franklin D. Roosevelt como ação voltada para artistas após a Grande Depressão de 1929, quando quinze milhões estavam desempregados ( $20 \%$ da população à época), e por volta de dez mil deles eram artistas registrados que acabaram sendo os primeiros beneficiários da lei. A contrapartida da produção, entretanto, não livrava essa iniciativa de seu caráter absolutamente assistencialista e emergencial. No meio teatral, mesmo o big business da Broadway em New York ficou prejudicado pela crise geral, com uma queda de mais de $70 \%$ no número de produções antes e depois de $1929^{281}$.

A cena alternativa de metrópoles como New York e Los Angeles ainda florescia graças ao ativismo político de muitos dos seus integrantes, que culminou na emergência do agitprop, fazendo com que até mesmo artistas europeus proeminentes como Bertolt Brecht se mudassem para o país para escapar do ambiente hostil às artes no qual se encontrava. Mas esta cena seguia de forma totalmente marginalizada e fora do alcance de qualquer política de promoção e fomento comercial ou estatal de suas produções. Os grupos se mantinham de modo um tanto semelhante aos filodramáticos em São Paulo, se apresentando em clubes fechados - por causa da clandestinidade política em que sua luta estava inserida - e se mantendo em concursos e festivais onde exercitavam a solidariedade mútua na manutenção de suas atividades ${ }^{282}$.

\footnotetext{
281 in: WILSON, Graff B. Three Hundred Years of American Drama and Theatre: From Ye Bear and Ye Cubb to Hair. Englewood Cliffs: Prentice Hall, 1973, p. 372

${ }^{282}$ Para maiores detalhes do teatro dos EUA neste período e da luta dos grupos de agitprop pela sobrevivência, Cf. em: COSTA, Iná Camargo. Panorama do Rio Vermelho: Ensaios sobre o Teatro Americano Moderno. São Paulo: Nankim Editorial, 2001, p. 89-106
} 
Ao se pensar que a única política estatal para as artes dos Estados Unidos nos anos 1950 seguia sendo o projeto concretizado após a Grande Depressão, entende-se a razão de, em um momento de pujança econômica do país no pós-guerra, o modo de produção teatral do país ter se tornado mais capilarizado e diverso. Os teatros regionais em cidades mais distantes passaram a atrair muitos artistas pela possiblidade de expressarem temas que não costumavam entrar no circuito comercial dos grandes centros. Também é desse momento, mais precisamente de 1949, a instituição de uma liga de teatros "Off-Broadway" em New York, onde os custos de montagem eram de apenas pouco mais de $6 \%$ do preço médio no endereço teatral mais caro da cidade (oitenta mil, contra cinco mil dólares) ${ }^{283}$, que redundaria pouco tempo depois num novo desdobramentos: os teatros "Off-Off-Broadway", ainda mais alternativos.

De maneira irônica, enquanto o Brasil e o mundo ocidental se voltavam cada vez mais para o modo estadunidense de produção capitalista, o teatro nacional pareceu buscar um outro modelo. A ascensão do TBC e de outras companhias que surgiram a partir do seu exemplo e legado inflacionou o mercado brasileiro, ao mesmo tempo que deu um apuro técnico inédito à cena nacional. Porém, de forma também diferente ao que ocorreu nos Estados Unidos, os investimentos privados eram por demais concentrados nas grandes metrópoles do país, São Paulo e Rio de Janeiro. Quando companhias como o TBC visitavam cidades como Porto Alegre, se aproveitavam da estrutura erguida em outros tempos em que se buscava uma maior equiparação regional.

Ainda assim, entre os grupos mais bem estabelecidos, aparentemente não houve grande mobilidade em relação aos meios de manutenção, com a grande exceção talvez sendo o TBC, que passou de um modelo totalmente privado em seu início para um onde o poder público parecia ter controle quase total sobre o estabelecimento, salvo o poder de decisão sobre o repertório. No final da companhia fixa do TBC em 1964, em todas as demais instâncias havia participação estatal, graças aos empréstimos nos quais o TBC se viu amarrado por anos a fio. É possível, pois traçar um paralelo entre o TBC, os que seguiam o sistema público vigente para o teatro e os que se estabeleceram em modelo puramente privado em sua administração, estabelecendo relações de proximidade entre eles durante os anos 1950 e 1960.

283 in: RUBIN, Don; SOLO'RZANO, Carlos. The World Encyclopedia of Contemporary Theatre: The Americas. Londres: Routledge, 2000, p. 396 
Considerando que o caso das companhias Tônia-Celi-Autran e Cacilda Becker, oriundas do $\mathrm{TBC}^{284}$, conscientemente seguia diretrizes próximas, porém diversas, de sua companhia de origem utilizando-a apenas como parâmetro, Becker seguiu um modelo de negócios um tanto mais ousado: os programas de suas peças pareciam ter muito mais patrocinadores (como a Air France, que aparecia desde as primeiras peças da companhia), graças ao poder de atração de atriz para dar maior influência às marcas que se associavam a ela. Becker também conseguia transitar com desenvoltura por meios extremamente díspares entre si, como a militância pela causa teatral e a televisão. Apesar de tal dicotomia ter the trazido problemas que possivelmente aceleraram os problemas de saúde que acarretaram em sua morte em 1969, não se pode negar que ela levou adiante seu modelo de negócios sem considerar mudar de rota.

A Companhia Maria Della Costa também pode ser vista de modo particular quanto à criação de um outro modelo de companhia, muito por terem na verdade feito o caminho oposto ao do TBC, saindo de uma maior dependência pública para um modo de produção privado. Trabalhando no Rio de Janeiro desde 1942 com um grupo chamado Os Comediantes, Della Costa vinha colecionando, junto ao Teatro Popular da Arte (de Miroel Silveira) insucessos em pedidos feitos ao SNT para que lhes permitisse ocupação do Teatro Ginástico no Rio, então administrado pelo órgão estatal.

O grupo seguidamente perdia preferência no seu uso para órgãos do governo, como o Curso Prático do SNT, ou para companhias mais estabelecidas como a DulcinaOdilon, dando razão à regra informal que colocava que grupos recém-estabelecidos tinham naquele momento mais dificuldade para receber subvenção estatal, pelos critérios estarem mais ligados “(...) à relação pessoal, o jogo de influências, do que a uma concepção estruturada ou mesmo a adoção de um projeto formulado no jogo social"285. Após terem conseguido subvenções mínimas no final da década, da ordem de cinquenta mil cruzeiros - um sexto do capital necessário para sua manutenção -, o grupo chegou titubeante aos anos 1950, mudando seguidamente de nome fantasia - Os V Comediantes, Comediantes Associados -, sem saber se teria uma atuação mais profissional e contínua.

\footnotetext{
${ }^{284}$ Cf.nas p. $162-4 ; 211$
}

285 BRANDÃO, 2009, p. 142 
Tudo mudou com a atuação de Sandro Polloni, que como empresário (ainda assinando como Polônio) fechou contrato para uma montagem de "Anjo Negro", de Nelson Rodrigues - montada por iniciativa do próprio dramaturgo -, com Ziembinski na direção e Itália Fausta sendo a primeira a assinar carteira profissional pelo Teatro Popular da Arte, em $1^{\circ}$ de junho de 1950 - seis meses depois do TBC. Com isso, Dalla Costa se juntou a eles após o fim oficial do grupo Os Comediantes. De certa forma, a atuação de Polloni junto a Ziembinski, Fausta e Rodrigues pareceu ter confirmado o fato de que foi preciso ter contato com pessoas experientes e respeitadas no meio teatral, para que a partir disso as portas se abrissem ao trabalho dos artistas batalhadores que buscavam seu espaço.

Porém, no processo contemplado, havia a ressalva de que a sede do grupo, condição para a assinatura na carteira profissional de Fausta, constava como sendo São Paulo $^{286}$. Foi a partir disso que Polloni e Della Costa entraram em sociedade, que redundou em casamento, e assim passaram a buscar um lugar próprio em São Paulo, encontrando-o primeiro no recém-inaugurado Teatro Cultura Artística, onde encenaram "No Fundo do Poço", de Helena Silveira e Jamil Haddad, já com a nova razão social do grupo - Teatro Maria Della Costa (TMDC). Posteriormente, encontraram um terreno na Rua Paim, na Bela Vista, onde estabeleceram seu teatro que foi paulatinamente sendo construído e então inaugurado em outubro de 1954.

Desse modo, a companhia passou por inúmeras fases, tal como o $\mathrm{TBC}$, indiretamente tendo mecenato de recursos públicos antes de seu estabelecimento formal como grupo amador, mas após isso ela conseguiu levar adiante um modelo de negócios altamente capitalista para uma iniciativa teatral, sendo após sua inauguração um dos teatros mais alugados para temporadas de companhia alheias nos anos 1950, por vários fatores como seu equipamento moderno, boa localização e espaço amplo - a capacidade de público era equivalente à do $\mathrm{TBC}$, com maior possibilidade de ampliação -, construindo uma visão de negócios na qual se investiu quando houve a oportunidade, não deixando de certo modo de ter algum tipo de ligação solidária com os artistas do teatro que colocava em seu local próprio.

${ }^{286}$ BRANDÃO, 2009, p. 176 
A maneira como a Companhia Maria Della Costa se estabeleceu mostra de certa forma a existência de relações problemáticas entre os diferentes atores responsáveis pela concretização de uma produção teatral: o produtor, o mecenas e o patrono/líder da companhia. Particularmente, quando esse mecenato é configurado pelo Estado. Roberto Parreira, ainda que tratando da indústria do cinema, coloca uma perspectiva interessante a respeito dessas questões, que redundariam em uma espécie de dependência por parte de um produtor que tem este tipo de postura, independente da expressão artística:

Os principais problemas nas relações do Estado com os produtores culturais se situam, creio eu, [...] quando a fixação excessiva na estratégia "produzir e produzir, porque a quantidade gera a qualidade", acaba se transformando numa política de subsídios. A perversão ocorre quando a figura do "produtor cultural" acaba sendo substituida pelo "captador de recursos", que - este sim - acaba se acomodando à prática do subsídio. Ele se "organiza” em função do subsidio. ${ }^{287}$

Parreira parece ter experimentado tais problemas na relação com demais executivos culturais, quando da criação da Fundação Nacional para as Artes $\left(\right.$ FUNARTE) ${ }^{288}$ em 1975, da qual foi seu primeiro diretor. Para ele, havia uma possível contraposição entre uma visão de fomento e de apoio paternalista na divisão dos recursos disponíveis por determinado órgão governamental. O fomento à uma atividade seria "uma criação coletiva", realizada por agentes que por não serem “(...) dependentes do Estado, também não se comportam como donatários, apropriadores, mas como gerentes, com interesse em operacionalizar o Estado" ${ }^{\text {289 }}$ para atividades produtivas. O paternalismo então seria tudo que limitasse a essa relação mais impessoal a um projeto.

No caso específico da arte teatral, importante destacar que esses critérios mais impressoais dificilmente eram considerados, apesar de que para alguns analistas uma análise que leve em consideração outros fatores não deveria exatamente ser algo considerado totalmente condenável. Para explicar essa posição, é preciso pensar que, se apenas critérios técnicos fossem considerados, grupos economicamente favorecidos levariam todo subsídio e as necessidades de outras companhias seriam negligenciadas.

\footnotetext{
${ }^{287}$ apud MICELI, 1984, p. 232

288 a Fundação Nacional das Artes (FUNARTE) é um órgão do governo federal subordinado ao Ministério da Cultura (MinC) ou à secretaria correspondente. Tem por objetivo fazer a promoção e salvaguarda de inciativas do Estado, como complemento às ações do ministério.

${ }^{289}$ MICELI, Op.Cit., p. 237
} 
Para justificar isso, é preciso considerar a possibilidade de estabelecer proteções especiais para companhias inseridas de forma precária no mercado. O próprio exemplo dos Estados Unidos, onde a intervenção estatal no teatro é limitada e enfrenta “(...) questionamento mais sério (onde) o teste do mercado é a regra" ${ }^{, 290}$, deve ser retomado pois em 1965 é criado o National Endowment for the Arts (NEA - Fundo Nacional de Doações para as Artes), uma política mais abrangente e bem menos paternalista que a anterior, mas que garante o acesso aos meios de produção para os grupos pretendentes que atendem seus critérios técnicos, ao mesmo tempo que promove uma maior chance de diversidade cultural ao público.

Nesse sentido, apesar do NEA, o programa mais duradouro de fomento cultural nos Estados Unidos, não ser considerado de caráter sócio-político (ou seja, teoricamente não consideraria tais critérios como preponderantes no estabelecimento de prioridades para recebimento de recursos), tem como prioridade uma redistribuição mais equânime das oportunidades de expressão artística, facilitando a vida tanto de empresas que doariam recursos para o fundo esperando por contrapartidas, como de iniciativas culturais fora dos grandes centros que poderiam trabalhar projetos de forma mais profissional e duradoura ${ }^{291}$.

Esse tipo de provimento de atividades culturais é seguramente diferente do que ocorre na França, cuja estrutura inspirou de certa forma a hierarquização por muito corrente nos órgãos estatais brasileiros, em sua divisão por departamentos específicos às áreas artísticas e priorização da educação e do lazer nas atividades promovidas ${ }^{292}$. Por isso, é importante destacar as diferenças e proximidades entre companhias e escolas de teatro em relação a um ou outro modelo. Suas necessidades de manutenção e produção seriam parecidas, com a maior diferença entre elas se dando nos meios para tal subsistência, e por conseqüência na maior busca por apoios estatais, privados ou mesmo associativos.

\footnotetext{
${ }^{290}$ COELHO, Edmundo Campos; PECHMANN, Sergio. Teatro: Mercado e Intervenção do Estado, in: MICELI, 1984, p. 150

${ }^{291}$ Cf. em BAUERLIN, Mike; GRANTHAM, Ellen. National Endowment for the Arts: A History - 19652008. Washington: Library of Congress, 2008

${ }^{292}$ Cf. em URFALINO, 2015, p.36-7; Por outro lado, Althusser colocaria esse modo de priorizar a formação cultural do cidadão através da educação como “(...) reprodução da qualificação da força de trabalho (no sistema capitalista) não "em cima das coisas", (...) mas, e cada vez mais, fora da produção, através do sistema escolar capitalista, e outras instâncias e instituições" (1980, p.20).
} 
Entre as décadas de 1940 e 1960, eram facilmente encontráveis grupos estudantis que preferiam se apresentar em espaços alugados alheios, e outros com sede própria onde chamavam parceiras com outros grupos para ajudar a cobrir tais despesas. Muitos desses grupos, como a EAD e o Teatro Paulista do Estudante (TPE), que contribuíram sobremaneira para o TBC em suas fases inicial e final ${ }^{293}$, eram espaços de formação que apresentavam peças para lançar seus pupilos em grupos estabelecidos, geralmente ligados a uma associação entre grupos na mesma posição. Apesar de que na EAD alegadamente se diz que ambos espectros ideológicos conviviam sem maiores rusgas, era fato que os mais à esquerda preferiam um outro modo de organização ao saíem de seus locais de formação.

A partir desse espírito de afinidade estética e ideológica, houve então a ascensão de associações da classe como a Federação Paulista de Amadores Teatrais, dos grupos de escola e de vanguarda, e a UPCT, de artistas profissionais. Em um movimento semelhante ao da ascensão dos grupos de agitprop nos Estados Unidos dos anos 1930, essa política de maior independência dos grupos oriundos de locais como o TPE redundou na consolidação de grupos como o Arena e o Oficina. Conforme se adentrava nos anos 1960, começou a haver uma separação mais forte entre grupos de teatro e as companhias puramente privados, ainda que eventualmente elas fossem diminuindo ou se tornando totalmente independentes entre si devido à ligação com tais associações no decorrer do tempo, conforme se encontravam estabelecidos e estáveis.

\subsection{A Fase Final do TBC: Articulação do Teatro com Grupos e Coletivos Pós-1964}

O completo desmantelamento da estrutura do TBC, fechando a companhia fixa do teatro e deixando-o em definitivo sobre os auspícios da administração da SBC, que assumia a direção sobre como manter o teatro aberto, levou à situação limite de fazer com que o teatro voltasse para um estado ainda mais regressivo em relação a seu início, sem a vibração e entusiasmo de outrora. A SBC ainda tentou salvar o ano de 1964 introduzindo o que seria sua nova diretriz ao menos até o fim do ano, quando haveria nova diretoria: alugando o TBC para quem quisesse ocupar o espaço "mítico" do teatro brasileiro.

293 O TPE era ligado ao PCB, fazendo deste um grupo militante de vanguarda no país. Deste grupo, saíram Gianfrancesco Guarnieri e Raul Cortez, que se revelaram no Arena e passaram pelo TBC na fase final da companhia 
Em setembro de 1964, menos de dois meses após o imbróglio do fechamento da companhia, estreia no espaço "Nu para Vinícius", de Renata Palottini e Lauro Cesar Muniz. Nesse novo início, Alberto D'Aversa foi o primeiro a propor encenações próprias para o espaço, com três peças no espaço de um ano, tendo certo êxito na montagem em 1965 de "Espectros", de Henrik Ibsen, com Lelia Abramo e Sebastião Campos no palco. Essa encenação se tornou possível graças a uma turnê acertada previamente que garantiu recursos à sua produção, fazendo com que a companhia de D'Aversa pudesse também percorrer o Brasil com a montagem.

Dentre as peças que alugaram o espaço entre 1964 e 1965, um destaque do período é a montagem por uma companhia recém-formada, o Grupo Decisão, de um texto que fazia muito sucesso no Rio de Janeiro. "O Patinho Torto", do mineiro Coelho Neto, um texto peculiar escrito em 1917 e publicado apenas sete anos depois, e que nunca havia sido encenado por causa do seu tema tabu: uma protagonista transexual que muda seu sexo por ação da natureza. O Grupo Decisão, formado no ocaso do TBC junto à efervescência dos grupos jovens e militantes, era dirigido por Antonio Abujamra, que havia sido assistente no TBC na montagem em 1961 de "Almas mortas", de Gógol.

Foi o máximo que se tomou de nota a respeito do que aconteceu ao prédio do TBC logo após a dissolução de sua companhia fixa. A SBC com a posse de sua nova diretoria em 1965 decidiu de uma vez levar adiante sua intenção de abrir o prédio do TBC apenas para quem se dispusesse a alugá-lo para apresentações, concentrando seus esforços administrataivos na venda de cotas para seus associados e ao público em geral. Nesse sentido, a nova administração conseguiu otimizar melhor os gastos expandindo a atuação da Sociedade, pois tais cotas lhes permitiram comprar duas salas de teatro na Avenida São João, onde ficavam o Teatro das Nações e o Teatro de Bolso ${ }^{294}$.

A nova composição da SBC traz ainda o nome de Zampari como presidente "perpétuo e benfeitor", como homenagem e tambem como mostra de que ele ainda mantinha participação e simpatia perante a Sociedade. Além de Zampari, outro que

\footnotetext{
${ }^{294}$ O Teatro das Nações, conhecido mais tarde como Teatro Dercy Gonçalves, era um teatro de peças infanto-juvenis que teve sua continuidade prejudicada a partir da década de $1970 \mathrm{com}$ a construção do Minhocão, construído diante de sua fachada, e acabou demolido em março de 2010, tornando-se um estacionamento. O Teatro de Bolso, chamado de Sala Oscarito, era um anexo do Teatro das Nações.
} 
permaneceu no organograma após o fim da companhia do TBC foi Guilherme Vitale, tendo originalmente entrado na diretoria por indicação da CET. Assim, o quadro completo com a nova composição segue abaixo:

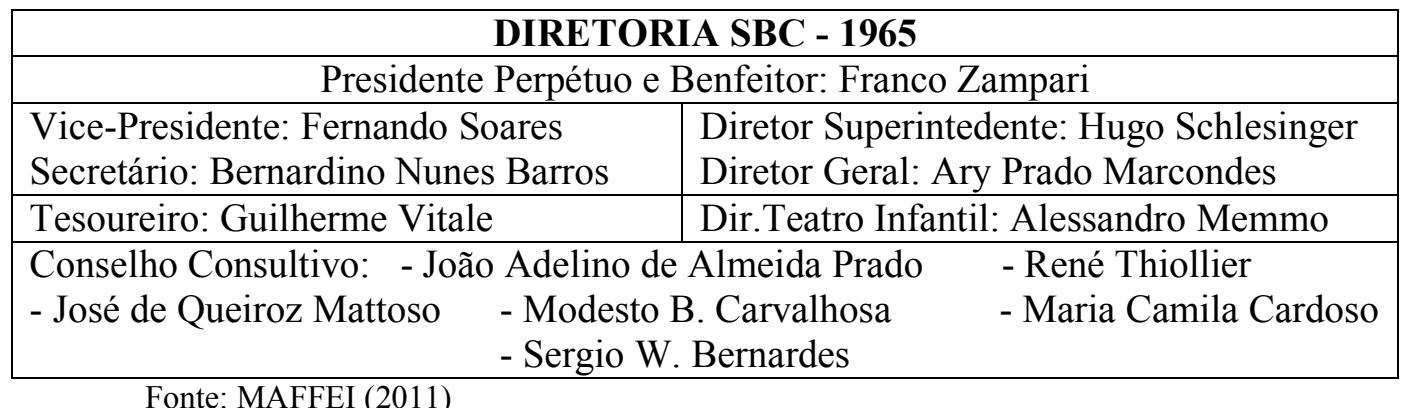

Essa nova estratégia da SBC, que coloca no TBC uma pessoa responsável peloemergente cenário do teatro infantil, mostra que além daquela nova direção buscar algo que pudesse ser revertido em um lucro imediato, havia uma grande fragmentação na atuação teatral paulistana nesse momento pós-golpe civil-militar. Naquele momento, o clima de busca pela sobrevivência a curto prazo levava os mais fortes a se agruparem em torno de seus interesses, resistindo melhor que os mais fracos, incluindo os artistas.

Um espaço surgido no período que parecia ter se tornado um modelo para essa nova direção da SBC era o Teatro Ruth Escobar, aberto em 1963 na área mais alta da mesma Bela Vista do TBC. Capitaneado pela empresária portuguesa junto a investidores de sua comunidade, tinha uma composição interna que comportava espetáculos de diferentes tipos, desde experimentais até de massa. Como Maria Della Costa, ela por algum tempo preferia alugar o teatro a montrar uma companhia própria para ocupá-lo, pelo fato do local ser de sua propriedade.

Nesse momento de ocaso em que se passava certa desintegração no meio teatral, o TBC acaba trazendo para si alguns daqueles de quem ele aparentemente parecia mais distante. Augusto Boal, estabelecido no Teatro de Arena, presta uma homenagem ao TBC encenando ali extensão da temporada de seu espetáculo musical "Arena Canta Bahia" em setembro de 1965, com a presença do melhor da música baiana e brasileira de então - Caetano Veloso, Gilberto Gil, Maria Bethânia, Tom Zé, Jards Macalé, entre outros artistas $^{295}$.

${ }^{295}$ Cf. em MAFFEI, 2011 


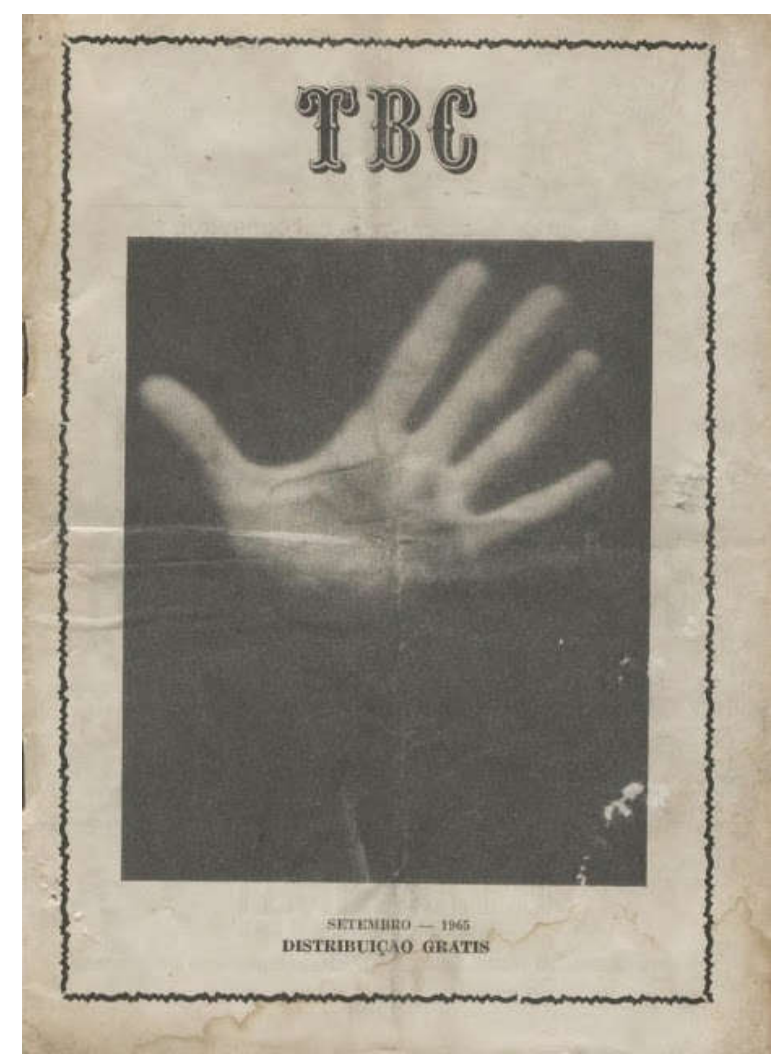

Imagem 25 - Capa do programa de “Arena Canta Bahia” no TBC. (MAFFEI, 2011)

José Celso Martinez, do Teatro Oficina, também presta reverência ao TBC ao dirigir em 1966 uma superprodução para "Os Inimigos”, de Górki, protagonizada por Celia Helena e Etty Fraser, onde também homenageia um trabalhador dos bastidores do teatro que muito fez pelas apresentações naquele espaço: o maquiador Leontij Timoszczenko, que chegou ao TBC quase junto de Ziembinski e acabou lá permanecendo por mais tempo que ele. Grupos como o Oficina, de característica mais independente oriundos dos movimentos de vanguarda dos anos 1950, precisavam muito voltar a se associar entre si. Nesse momento, outros que haviam surgido há pouco, como o Decisão, sucumbiriam pouco depois em 1966 por causa da perseguição causada pelos agentes da ditadura civil-militar na intensificação da censura e também pelos que, incitados pelos ocupantes do poder a caçarem os "comunistas" da nação, investiam contra os artistas independentes por considerá-los como “(...) dos elos mais fracos do campo da esquerda"296, campo esse identificado como artífice de todos esses grupos.

296 Segundo o coronel Luiz Helvécio de Silveir Leite, integrante do CCC (Comando de Caça aos Comunistas), esse era um dos motivos dos artistas de teatro terem se tornado alvos do grupo, com 
O último suspiro de tentativa de articulação nesse contexto conturbado se dá quando Cacilda Becker, que havia sido a primeira a liderar a UPCT, assume a presidência da CET em lugar de Décio de Almeida Prado em março de 1968. Cacilda não perde tempo para tentar reorganizar os que quisessem “(...) contribuir para uma tomada de posição" ${ }^{297}$, nas palavras dela, fazendo reuniões abertas todas as segundasfeiras, dia tradicionalmente livre do teatro, alémdas reuniões reservadas em seu apartamento. Para garantir a exibição da Feira Paulista de Opinião do Arena ${ }^{298}$ em junho no palco do Teatro Ruth Escobar, discursa na estreia junto a Maria Della Costa e Ruth Escobar dando o tom de um “(...) ato de rebeldia e desobediência civil, um protesto definitivo dos homens de teatro contra a censura em Brasília"299 chamando o ministro do MEC à época, Gama e Silva, a rever a legislação que ainda estava em vigor desde 1946 e tinha voltado a ser aplicada com rigor.

Contudo, o recrudescimento do regime cresce. Becker começa a perder trabalhos e se afasta da CET em novembro. Mesmo o Arena e o Oficina não passam incólumes, com ataques sofridos pelo Oficina durante temporada de "Roda Viva", de Chico Buarque, em São Paulo e Porto Alegre, fazendo sua temporada ser definitivamente interrompida em outubro de 1968. Após o fechamento definitivo do regime com o AI-5 em 13 de dezembro, esses sinais de resistência acabam de vez: Cacilda Becker morre de aneurisma em maio de 1969, o Oficina se desintegra no exílio e o Arena resiste até 1972, sendo depois fechado.

Por toda a década de 1970, o cenário volta a ser o da busca pela manutenção da atividade para reorganizar os modos de produção e de associação entre os pares. Associações novas e resistentes dentro da estrutura oficial são as principais chaves para se buscar esses novos modelos. Em 1972, é criada a Associação Paulista de Produtores Teatrais (APETESP), uma articulação importante que garantiria o contato entre o capital (empresário), os assalariados (artistas) e os intermediários (produtores) encarregados de

ataques e ameçacas constantes. Cf em: MEMORIAL DA DEMOCRACIA, CCC volta à cena em ataques a teatros: 18 de julho de 1968, Disponível em: <www.memorialdademocracia.com.br/card/ccc-volta-acena-em-ataques-a-teatros> Acessado em 17 de Agosto de 2019

${ }^{297}$ BARROS DE ALMEIDA, 1987b, p. 138

298 Sobre a produção e o contexto do espetáculo, Cf. em: GARCIA, Miliandre. Da resistência à desobediência: Augusto Boal e a I Feira Paulista de Opinião (1968). In: Revista Varia historia, vol.32, n.59. Belo Horizonte, mai/ago 2016, p. 357-398.

${ }^{299}$ BARROS DE ALMEIDA, 1987b, p. 139 
fazer chegar o produto teatral aos remanescentes neste mercado ${ }^{300}$. Além das soluções de mercado, até o fim da década surgem outros meios associativos que refundam o conceito de grupo, desgastado com o desmantelamento da maioria das companhias de vanguarda que chegaram ao fim dos anos 1960 com intenções profissionais.

Dentro dessa rearticulação da cena teatral, um grupo que se destaca por conseguir se manter seu distanciamento do mercado profissional é o Teatro Popular União e Olho Vivo, com sede própria construída por Idibal Pivetta (pseudônimo de Cesar Vieira) e Neriney Moreira no Bom Retiro. Tendo surgido em 1966 a partir de encenações amadoras no Centro Acadêmico de Direito da USP - tal qual o Ofícina -, e dando novo valor à estética circense e engajada, utilizando dos artifícios e a estética desenvolvidos por Augusto Boal e o Arena, o grupo se manteve à margem para não mais sofrer sanções da censura e ser um centro de resistência cultural à política vigente.

O novo "teatro de grupo", sem pensar num primeiro momento em uma articulação coletiva, continuou levando novas experimentações sob uma lógica de cooperativa interna, em que a criação coletiva e a funções fluidas dentro do grupo levavam a uma divisão equânime dos ganhos e custos de produção. Esse sistema, que em São Paulo é representado na década de 1970 por grupos como Pessoal do Victor, Teatro do Ornitorrinco, Mambembe, entre outros, logo se torna uma articulação maior após a fundação em 1979 da Cooperativa Paulista de Teatro (CPT), que a partir de uma sistematização de procedimentos comuns faz com que seus associados possam se tornar uma alternativa viável de organização.

Outra mobilização em 1979 engajou o meio teatral em torno do TBC como não se via desde as campanhas da CET pela salvação do teatro no início dos anos 1960. Antonio Abujamra, um dos integrantes do Grupo Decisão nos anos 1960, assumiu então a direção do TBC com um projeto completo de recuperação. Seu projeto de reforma inaugurou novas salas internas - nomeadas como Sala de Arte, Assobradado, de Câmara, D'Aversa e Ziembinski - aptas a receber apresentações teatrais em modelos afins com a estética teatral em voga desde os anos 1960 e 1970 com melhor estrutura e maior proximidade entre a encenação e a plateia, sem a necessidade do palco italiano.

\footnotetext{
${ }^{300}$ NOVAES, Adauto (org.). Anos 70: ainda sob a tempestade, São Paulo: Senac, 2005, apud PATRIOTA, 2012, p. 75
} 
A reforma obedeceu resolução de tombamento publicada em 22 de outubro de 1982 protocolado junto ao CONDEPHAAT - órgão estadual de preservação do patrimônio histórico - pela Associação Paulista de Críticos de Arte (APCA). O tombamento do prédio do TBC traz uma história curiosa da relação entre pessoas do meio teatral e autoridades. No caso, uma autoridade que tambem era artista, João Carlos Martins, pianista e então Secretário de Cultura do estado. A história de como isso aconteceu segue abaixo:

Sobre o tombamento do TBC, conta João Carlos Martins, que a necessidade surgiu pelas mãos de Antonio Abujamra. Lembra que um dia, quando estava estudando piano em seu gabinete, a porta de repente se abriu, e sem ser anunciado, Abujamra entrou com aquele seu jeito que ocupava logo o espaço todo onde quer que estivesse ou chegasse.

Abujamra: 'Eu era diretor do Teatro Brasileiro de Comédia, Só que eu não tinha dinheiro e tinha quatro salas funcionando. [...] Ai o que aconteceu? O dono do prédio disse que ia tirar a gente de lá e abrir um supermercado. Então eu, com a minha astúcia, com a minha canalhice, com a minha sem-vergonhisse - como ser artista num país tão trágico como o Brasil? -, eu peguei todos os documentos do TBC, tudo o que tinha feito no passado, e falei: Vou falar agora com o Secretário da Cultura. Peguei os papéis e fui até ele. 'Peraí, não pode entrar, ele está ocupado...não, não'. [...] Eu entrei, sentei numa cadeira ao lado dele, fiquei esperando uma pausa e disse: 'Pode continuar a tocar com a esquerda, e por favor assine com a direita. Isto aqui é o tombamento do Teatro Brasileiro de Comédia. Se você não assinar, o TBC vai virar um supermercado'. Ele assinou e o TBC está ai. ${ }^{301}$

A decisão do tombamento do CONDEPHAAT contemplou as quadras compreendidas pelas ruas São Domingos, Catorze de Julho e Jaceguai ${ }^{302}$, nas quais fica “(...) expressamente proibida a construção de novas edificações de altura superior ao prédio que abriga o TBC." Posteriormente, o tombamento foi reconhecido sem alterações pelo órgão municipal CONPRESP, faltando passar apenas pelo IPHAN, órgão federal de defesa do patrimônio histórico para garantir proteção completa a essa região contra a especulação imobiliária que segue há muito tempo estendendo seus projetos de "reurbanização" ao bairro da Bela Vista.

\footnotetext{
${ }^{301}$ CARVALHO, 2015

${ }^{302}$ Cf. mapa na p. 20
} 
Assim, em um esforço para trazer novos autores e diretores, interrompendo as iniciativas saudosistas que pairavam sobre o teatro nos anos anteriores, Abujamra produz ou encena diversos espetáculos, com destaque para "Os Órfãos de Jânio", de Millôr Fernandes, em 1981; "Morte Acidental de um Anarquista", de Dario Fo, em 1982; “A Serpente", de Nelson Rodrigues, em 1985; e "Esperando Godot”, de Samuel Beckett, em 1985. Um dos maiores sucessos de sua carreira, "Um Orgasmo Adulto Escapa do Zoológico", de Dario Fo, em 1984, traz a revelação de Denise Stoklos como performer solista.

Foi certamente o período mais prolífico do teatro desde o fim de sua companhia fixa, em que o espaço reviveu a aura de experimentação e influência na vida cultural paulistana dos idos dos anos 1950 e 1960. Foram realizadas ao menos cento e dez montagens em suas diversas salas entre 1980 e $1990^{303}$, algumas delas com temporadas duplas no teatro. Algumas encenações em destaque no período foram:

- "Happy End", de Bertolt Brecht e Kurt Weill, dirigida por Cacá Rosset, do Teatro do Ornitorrinco, em agosto e setembro de 1981;

- duas versões de Hamlet(o), versão de Giovanni Testori, em 1982 e 1985 (esta última com Antonio Abujamra);

- o musical "Bent", de Martin Sherman, em duas montagens de Roberto Vignati: de janeiro a maio de 1982 e de fevereiro a maio de 1987

- "Quem tem medo de Itália Fausta?", de Miguel Magno e Ricardo de Almeida, em duas temporadas, em 1983 e 1986

- "Morangos Mofados", de Caio Fernando Abreu, entre junho e julho de 1984;

- Ionesco, com “A Cantora Careca” em 1985 e "O Rinoceronte”, em 1986;

- "Explode Coração", de Enemir Franco, com três temporadas alternadas entre 1985 e 1987;

- "A Morte do Caixeiro Viajante", de Arthur Miller, feita por Domingos de Oliveira e João Carlos Serroni, com Cleyde Yáconis no elenco em agosto e setembro de 1986;

- “As Meninas", de Lygia Fagundes Telles, com dois anos em cartaz entre 1988 e 1990;

\footnotetext{
303 “Anexo: Fichas Técnicas - Peças Apresentadas na Cidade de São Paulo na Década de 1980”, in: MATE,
} 2008 
Em 1987, o projeto de ocupação do TBC capitaneado por Abujamra se encerrou por uma mal fadada negociação deste com Magnólia Mendes Ferreira do Lago, proprietária do prédio do teatro desde antes do processo de tombamento do prédio em 1982. As peças continuavam sendo apresentadas esparsamente, com o aluguel do espaço sendo pago à nova proprietária. Após esse momento, houve ainda uma última tentativa de ocupação artística contínua em 1998, em um princípio de junção entre artistas e empresariado através da iniciativa de Marcos Tidemann e da atriz Fezu Duarte. Após um aporte inicial de quatro milhões de reais, o espaço foi ocupado em 1999 com o nome de Novo TBC após nova reforma interna e externa"304.

Apesar da mais que louvável iniciativa de reativar um projeto de continuidade teatral num espaço com tamanho significado, a impressão é de que, como no final dos anos 1950, parecia que os investidores que colocaram seu dinheiro no TBC estavam um tanto desconectados das tendências ao seu redor. Nesse contexto, a luta do meio teatral era pela consolidação do modelo cooperativo de grupo vindo desde o fim dos anos 1970. A partir dessa luta conjunta que se deu o Movimento Arte Contra a Barbárie, iniciado em São Paulo em 1998 e que é considerado um movimento pioneiro para a plena execução da demanda dos grupos teatrais por maior continuidade nos projetos, transparência nos recursos alocados para as iniciativas culturais, e contra a crescente transferência de responsabilidade sobre a cultura do setor público para a iniciativa privada $^{305}$.

Um tanto alheio a esse movimento, Gabriel Villela assume no ano 2000 o posto de diretor do teatro, criando a Companhia de Repertório Musical, primeira companhia fixa no local desde os anos 1960. Seu projeto inicial era encenar uma trilogia de peças de Chico Buarque, "Ópera do Malandro", "Gota d'Água" e "Calabar" ou "Os Saltimbancos" - o diretor acaba optando pelos "Saltimbancos" mesmo nunca tendo trabalhado com teatro infantil até então - iniciando os trabalhos em setembro de $2000 \mathrm{e}$ terminando ao fim da temporada dos "Saltimbancos", já que "Gota..." acaba sendo encenada em outro local após Gabriel Villela desistir de levar adiante o trabalho no $\mathrm{TBC}$ em meio à série de montagens programada.

\footnotetext{
${ }^{304}$ Cf. em: SANTOS, Valmir, TBC não renova contrato e pode fechar, do jornal Folha de S. Paulo de 19 de dezembro de 2002, Disponível em: <https://www1.folha.uol.com.br/fsp/ilustrad/fq1912200224.htm> Acessado em 17 de agosto de2019

${ }^{305}$ BETTI, Maria Sílvia. A Lei do Fomento: Raízes e Desafios. In: DESGRANGES; LEPIQUE, 2012, p. 117-25.
} 
A não continuidade do projeto de Villela e o "nome-fantasia" ligeiramente diferente do original se devem muito a impasses com Magnólia Mendes Ferreira do Lago a respeito do direito de compra e do uso da marca do teatro. A proprietária endureceu a negociação com os novos arrendatários e exigiu mais dois milhões de reais além do que já havia sido depositado para fechar o negócio pela venda do espaço. Sem acordo, o teatro fechou novamente em 2002, sendo o projeto do Novo TBC o último de ocupação contínua do prédio até o momento.

Desde 2007, a FUNARTE negociou a aquisição do prédio como bem público para evitar sua maior deterioração e buscar reabrí-lo ao público tal qual ele era no seu apogeu, fazendo assim uma reforma mais profunda em suas instalações preservando a fachada. Esse projeto de reforma ${ }^{306}$, muito mais abrangente e completo do que todas as anteriores, incluíam projeto de um Memorial do Teatro Brasileiro no local, além da reativação das salas menores para espetáculos e ensaios. A reforma foi inicialmente orçada em dezessete milhões e seiscentos mil reais, com o montante já tendo sido destinado à obra a partir de 2012.

À época da compra, Sergio Mamberti, que também participou do Grupo Decisão nos anos 1960 - como Abujamra - e foi o diretor da FUNARTE responsável pela operação, anunciou que as obras estruturais começariam em 2010. Porém, a antiga proprietária criou problemas para a realização do laudo técnico alegando que o nome TBC lhe pertencia e que havia "vendido somente o prédio", pedindo quase sete milhões de reais a mais a título de indenização por parte do órgão, que alegava possuir tais direitos no contrato estabelecido. Sem que se soubesse se o impasse havia sido resolvido, em 7 de fevereiro de 2013 o então diretor da FUNARTE, Antonio Grassi, disse $^{307}$ que a entidade prometia a reabertura do prédio do TBC para o mês de outubro daquele ano, anunciando um novo investimento de treze milhões de reais na reforma da estrutura para completar as obras na estrutura interna do local.

\footnotetext{
${ }^{306}$ URDI ARQUITETURA. TBC - Teatro Brasilieiro de Comédia. Disponível em: <http://www.urdi.com.br/projetos-arquitetura-teatros-tbc---teatro-brasileiro-de-comedia> Acessado em 17 de agosto de 2019

${ }^{307}$ FIORATTI, Gustavo. Funarte pormete reabertura do TBC para mês de outubro. In: Folha de S. Paulo, 07 de fevereiro de 2013. Disponível em: $<$ https://acervo.folha.com.br//leitor.do?numero=19398\&anchor=5852440\&pd=27dc1f81ac39eef1c867 3df34d2b2590> Acessado em 17 de Agosto de 2019
} 
Porém, desde então os recursos originalmente alocados para a execução do projeto de reforma não chegaram e o teatro permanecia fechado, deixando de cumprir a função pública adquirida pela FUNARTE como órgão federal. Ainda que soe irônico que o teatro tenha acabado neste momento sob gestão pública sem que consiga utilizar do local e fazê-lo acontecer de verdade para o público, é preciso que todos os esforços pela manutenção e posterior reabertura do teatro não esmoreçam em vão. Porém, para tal coisa se concretizar faz-se imperativo reativar essa ligação entre o patrimônio preservado no prédio do teatro e a história que nele habita e pode ser representada pelas pessoas que viveram tudo aquilo e continuam entre nós.

Em junho de 2011, o Oficina realizou um projeto próprio chamado Dionizíacas Urbanas Antropófagas que abarcava a memória do TBC, com a encenação de terceira peça da série "Cacilda!", montagens feita pelo grupo entre 1998 e 2014 em homenagem à atriz, onde aproveitavam para revisitar a história do teatro no pais no século XX. Durante o cortejo que acompanhava a peça, o grupo parava em frente ao TBC fechado para reproduzir uma das cenas. Nela, Cacilda Becker "paria" ao estilo da personagem Macunaíma, ou seja, com a mãe em pé, simplesmente a toda a linhagem do teatro brasileiro de seu tempo e posterior a ela, para o público presente.

O cortejo passou por ruas que tem história no bairro: a São Domingos, onde passava o bonde na primeira metade do século XX; a Abolição, para lembrar a libertação dos negros escravizados; e a Jaceguai, onde se encontra o Oficina e o terreno vazio ao lado do teatro pertencente ao apresentador Sílvio Santos. Desde o tombamento do Oficina nos anos 1980, há um impasse quanto à vontade do apresentador de construir neste terreno torres comerciais que obscureceriam o teatro, cujo projeto de Lina Bo Bardi aproveita através de paredes espelhadas a luz natural para as encenações. Importante lembrar que o próprio Sílvio Santos tem um teatro próprio na mesma rua Jaceguai em terreno muito próximo ao Oficina, o Teatro Imprensa, fechado desde 2011 para reduzir custos do seu conglomerado empresarial ${ }^{308}$.

\footnotetext{
${ }^{308}$ As operações de salvaguarda de complexo industrial de Sílvio Santos incluíram a venda do Banco Panamericano no mesmo ano, em operações que envolveram agentes do governo federal, pela participação que a Caixa Econômica Federal tinha em ações do banco, na venda do banco para o BTG Pactual. O Banco Pan, surgido dessa operação, liderava em julho de 2019 o ranking do Banco Central de reclamações de clientes por serviços mal prestados.
} 
No entanto, os caminhos que envolvem quaisquer negociações entre entes públicos e privados nunca vão por uma linha reta. De surpresa, no início de setembro de 2017, o então ministro da Cultura, Sergio Sá Leitão, alegava que não tinha condições de bancar a reforma, nem mesmo de colocar funcionários para cuidar do espaço quando estivesse pronto, no que faria um edital para chamar a iniciativa privada a participar do processo. No que tange o fato de o teatro ter sido feito como um empreendimento privado, era preciso pensar que, por ele ser um bem público hoje, poderia gerar riquezas para o público geral como retorno desse investimento. Afinal, um dos pilares do movimento é a alegação de que todo o dinheiro investido até aquele momento pelos órgãos públicos seria perdido em definitivo, com o investimento público servindo para usufruto do grupo privado que ganhasse a licitação.

Após tentativas frustradas em se buscar conversar com o ministro sobre tal decisão, considerando terem sido gastos cerca de vinte milhões de reais até o momento do anúncio de sua privatização, havia o receio de que tal anúncio poderia ser definitivo para a sorte do edifício, ao se tratar da concessão do local à iniciativa privada como algo sacramentado sem que houvesse publicidade sobre o projeto a ser implementado. Com o mesmo edital sendo tambem adiado quanto ao anúncio de seus detalhes, algo fundamental dentro da concorrência pública para se manter um princípio de impessoalidade no processo e evitar que se pensasse haver uma negociação prévia a seu respeito, houve novamente um princípio de nova união dos artistas para evitar que isso fosse adiante daquela maneira.

Por isso, começaram as primeiras reuniões do nascente movimento "Salvar o TBC" que viria a ser a Associação de Amigos do TBC e do Teatro Brasileiro (ATBC), uma entidade de fins não econômicos que busca, segundo o artigo $4^{\circ}$ de seu Estatuto, “(...) ter por finalidade promover a cultura e a educação, com o propósito de incentivar e defender as artes cênicas brasileiras e sua dramaturgia, bem como preservar a memória e proteger o patrimônio cultural e histórico do teatro brasileiro",309, além de entre outras ações “(...) promover e realizar a colaboração, a cooperação e o intercâmbio com organizações de fins não econômicos e com o poder público para programas e projetos relacionados à sua finalidade social ${ }^{\text {"310. }}$.

\footnotetext{
${ }^{309}$ ESTATUTO SOCIAL ATBC, Cap. 2, Art. 4ㅇ, 2018

${ }^{310}$ ESTATUTO SOCIAL ATBC, Cap. 2, Art. 4으, inciso III, 2018
} 
O movimento começou angariando apoio em reuniões abertas, com a primeira delas sendo realizada no Espaço Satyros, na Praça Roosevelt, espaço de resistência teatral que ocupa o baixo Centro da cidade desde 2000. Na segunda reunião, em 20 de setembro de 2017, é elaborada uma carta manifesto do movimento ratificada naquele dia por setenta e três pessoas presentes em assembleia, e na internet por mais de três mil assinaturas on-line em sites de petição pública e nas redes sociais. Joao Wady Cury, no jornal $O$ Estado de $S$. Paulo do dia seguinte, atestou em sua coluna quais eram as intenções do movimento:

Um grupo de 40 artistas e curadores ligados à classe teatral paulistana escolheu, na tarde desta quarta-feira, 20, em reunião no Teatro Oficina, quatro representantes para formar uma comissão e discutir a questão da privatização do Teatro Brasileiro de Comédia (TBC) com o Ministério da Cultura. O grupo deve procurar o ministro Sergio Sá Leitão nos próximos dias para requerer uma audiência. [...]

O movimento foi iniciado como reação dos artistas à decisão do MinC de repassar o TBC à iniciativa privada por meio de um edital que, segundo o ministro, seria publicado ainda este ano. $O$ teatro, que pertence à Fundação Nacional de Artes, FUNARTE, está fechado há dez anos. [....]

Aqui, o documento que resultou do encontro:

\section{SALVAR O TBC PARA O BRASIL}

A classe teatral paulista repudia o anúncio de privatização de um bem público da importância histórica do TBC de São Paulo, legenda que encerra boa parte do patrimônio imaterial do teatro brasileiro junto aos teatros Oficina e Arena. Repudiamos com veemência a perspectiva desse teatro tornar-se um empreendimento puramente comercial.

Atores e atrizes, diretores, técnicos, pedagogos e produtores teatrais vêm a público lembrar que o TBC, além de constituir bem tombado em mais de uma instância de preservação do patrimônio, assim como os citados Oficina e Arena (este também adquirido pelo MinC), já consumiu mais de 20 milhões de reais do erário público em processos de compra e reforma do imóvel.

$O$ edifício e a legenda TBC são patrimônio do teatro e do povo brasileiro e não podem figurar na "massa falida da Cultura", como essa área vem sendo tratada pelo atual governo federal. PELO DIÁLOGO da classe teatral com o Ministério da Cultura e a FUNARTE, a fim de estudarmos juntos alternativas ao projeto de privatização anunciado. 
Após os desdobramentos desse movimento em prol do teatro, em abril de 2018 foi fundada como entidade de classe a Associação dos Amigos do Teatro Brasileiro de Comédia do Teatro Brasileiro (ATBC), tendo entre seus fundadores e integrantes honorários atores como Sergio Mamberti e Denise Fraga, além de apoiadores entre artistas como Celso Frateschi, Nathalia Thimberg, Marcos Caruso, e Fernanda Montenegro; diretores como Amir Haddad; pesquisadores e produtores de teatro de várias partes do país, como Raimundo Matos de Leão, professor de Historia do Teatro da Universidade Federal da Bahia.

A constituição do núcleo diretivo da ATBC congrega pessoas de diversas formações e históricos dentro do meio teatral, desde críticos e pesquisadores, artistas e diretores a produtores de montagens e festivais de grande renome e histórico nas artes cênicas paulistas e brasileiras. Procurando manter suas ações na continuidade da memória do $\mathrm{TBC}$, lutam por sua reabertura sem descuidar de sua atuação pelas demandas do meio teatral e da socieade no tempo presente. Desse modo, os nomes componentes da direção da entidade seguem abaixo:

\begin{tabular}{|l|l|}
\hline \multicolumn{1}{|c|}{$\mathbf{1}^{\mathbf{a}}$ DIRETORIA - ATBC - 2018} \\
\hline $\begin{array}{l}\text { Presidente: Álvaro Machado } \\
\text { Vice-presidente: Ruy Cortez }\end{array}$ & Secretário: Américo Córdula \\
\hline \multicolumn{2}{|c|}{ Conselho Consultivo e Fiscal } \\
\\
\multicolumn{3}{|c|}{ Silvio Restiffe } \\
Guilherme Marques \\
João Carlos Couto \\
\hline
\end{tabular}

Abaixo, encontram-se detalhadas biografias dos integrantes da diretoria:

- $\quad$ Alvaro Machado - É jornalista e diretor da Opera Prima Editorial e Cultural. Traduziu e editou livros de literatura, artes plásticas, cinema e fotografia, entre eles "Orgia - os diários de Tulio Carella no Recife" (2011), da própria Opera Prima, e outros pela Cosac Naify como "A vulnerabilidade do ser", de Claudia Andujar, "Notas de Viagem", de Thomaz Farkas, e "Abbas Kiarostami. Como jornalista, foi repórter e editor em cadernos culturais dos jornais Folha de S.Paulo e O Estado de S. Paulo e da revista Carta Capital, também assinando inúmeros artigos em revistas especializadas em cultura. 
- $\quad$ Ruy Cortez - Diretor teatral na Companhia da Memória, a qual fundou e com quem realizou entre outras obras "Requiem para o Desejo" (2018) e "Karamazov" (2014). É sócio do Instituto Cultural Olhares e co-fundador e diretor artísticopedagógico do Centro Internacional de Teatro ECUM. Fez cursos do método Stanislavski na Faculdade do Teatro de Arte de Moscou em 2011, e atua desde 1999 na área de pedagogia teatral em instituições como Escola Superior de Artes Célia Helena, Teatro-Escola Célia Helena e Escola de Atores Wolf Maya.

- $\quad$ Américo Córdula - Entre 2005 e 2015 fez parte do MinC como Secretário de Identidade e Diversidade Cultural e Secretário de Políticas Culturais, atuando na implementação da Convenção da UNESCO sobre a Proteção e Promoção da Diversidade das Expressões Culturais, Conferência Nacional de Cultura, na elaboração da metas do Plano Nacional de Cultura e do Sistema Nacional de Informação e Indicadores Culturais. Atualmente é proprietário da Córdula Responsabilidade Cultural, onde presta consultoria em Políticas Culturais para a gestão pública e privada, consultor Unesco para a Rede de Cidades Criativas, professor no curso de Gestão Cultural da PUC-SP, e mestrando em Políticas para a Diversidade Cultural na FFLCH-USP

- $\quad$ Guilherme Marques - Produtor, gestor cultural e ator. É diretor-geral e idealizador da MITsp - Mostra Internacional de Teatro, do Centro Internacional de Teatro ECUM, coordenador-geral do Encontro Mundial das Artes Cênicas e do Centro Internacional de Pesquisa sobre a Formação em Artes Cênicas. Realizou coordenação, produção e/ou consultoria artística de diversos festivais artísticos nacionais e internacionais, como Festival Internacional de Teatro Palco \& Rua de Belo Horizonte; Festival Internacional de Teatro do Mercosul (Argentina); Festival Internacional de Teatro de Caracas (Venezuela)

- $\quad$ Stênio Ramos - Formado em Letras pela UNESP/Araraquara em 2005, foi também assessor de projetos especiais no Departamento de Formação Cultural, da Secretaria de Estado da Cultura de São Paulo, em 2007, tendo colaborado para implantação de projetos não contemplados pelo órgão ao longo de sua história, como a construção de políticas para a arte de rua, culminando no Encontro Paulista de Hip-Hop, evento de celebração dessa cultura que segue ativo na Secretaria até hoje. 
- Silvio Restiffe - Ator. Fundador do Círculo dos Comediantes onde realizou diversas montagens de Nelson Rodrigues com direção de Marco Antônio Braz. Em 2006 passa a integrar o projeto de pesquisa da Companhia da Mentira com a peça “O que você foi quando era criança?", de Lourenço Mutarelli. Com a Mundana Companhia e Cia Livre realiza a montagem "O Idiota", de Dostoiévski dirigida por Cibele Forjaz. Com a Velha Companhia participou das montagens de Kiko Marques "Cais, ou da indiferença das embarcações", "Crepúsculo" e "Sínthia". No cinema e televisão, participou de "Tatuagem" de Hilton Lacerda, "Jardim Europa" de Mauro Baptista Védia, "Permanência" de Leonardo Lacca e "A Serpente” de Jura Capela.

- João Carlos Couto - Ator, sociólogo, consultor, curador e programador de atividades culturais nas áreas de teatro e dança. Foi membro do Conselho Estadual de Cultura de São Paulo e Presidente da Comissão Estadual de Teatro (2008/2010), conselheiro da Comissão Nacional de Incentivo do MinC (2006/2009) e da Secretaria de Estado da Cultura (2013/2016). Desde 2004 é consultor da programação do Teatro Alfa. Trabalhou também nos Festivais Internacionais produzidos por Ruth Escobar entre 1995 e 1999, no Festival Internacional de Artes da Cena de São Paulo, no Festival Internacional de Teatro-Rio Preto, no Festival Iberoamericano de Teatro Mirada em Santos. Recebeu do Governo da França as condecorações de Chevalier e Officier des Arts et des Lettres.

\section{ATBC \\ Associação dos Amigos do Teatro Brasileiro de Comédia e do Teatro Brasileiro}


O epíteto "Do Teatro Brasileiro" foi adicionado à razão social da ATBC por uma sugestão dada por Denise Fraga em uma das primeiras reuniões da associação, no dia 05 de fevereiro de 2018, e primeiramente acatada pelo presidente Álvaro Machado para discussão na assembléia da diretoria. A intenção era aumentar o escopo de ações possíveis dos associados para buscar angariar apoio para causas de teatro com questões semelhantes às do TBC - com questionamentos quanto à sua gestão pública, ou com problemas para manutenção ou reinício de suas atividades.

Na época, a ATBC ainda não havia se constituído como entidade jurídica, pois isso se formalizaria apenas dois meses depois, tanto que também havia dúvida sobre se o modo de organização interno seria o de uma "associação", onde haveria anuidade, rateio de despesas, e outras questões administrativas a serem resolvidas entre os que porventura se associassem, além da diretoria recém estabelecida. Por fim, a proposta de alargar as ações e frentes de trabalho do grupo foi acatada pelos presentes, também com a definição dos objetivos primários da $\mathrm{ATBC}$, que seriam:

- Fortalecer a importância do prédio do TBC como núcleo da história do teatro brasileiro e a defesa do seu patrimônio histórico e cultural;

- Atentar ao fato de que a reivindicação por sua abertura e manutenção conclamou à abertura de associação em busca de se construir um apoio mais amplo, em vista do fato de que o TBC não estaria isolado das questões de outros equipamentos culturais públicos na região, na cidade e no país

- Ressaltar o caráter público do prédio e a importância de se terminar sua reforma já iniciada segundo o projeto original, e mantê-lo desse modo de forma que esteja em funcionamento e voltado para o público.

Essa definição de ações se fez necessária a partir da resposta dada pelos artistas e público a uma primeira campanha de adesão espontânea à causa feita pela diretoria nos teatros paulistanos em outubro de 2017, onde se publicizou a questão da reforma do TBC e das tentativas de privatização do espaço, acarretando no prejuízo do que havia sido feito. Com a publicidade de petições on-line e da página em rede social, percebeuse maior engajamento nesses meios do que respostas de adesão ao movimento, motivo pelo qual não foi ainda feita convocação para angariar novos sócios à associação. 
Ao mesmo tempo que luta pela manutenção do TBC como patrimônio público para que junto à sociedade civil sejam encontradas maneiras de negociar o término de sua reforma conforme o projeto original de 2008, a associação pretende lançar atenção sobre problemas semelhantes enfrentados por vários outros locais na cidade e no país. Como exemplo local, temos a mobilização iniciada em 2013 pela reabertura do Teatro de Arte Israelita Brasileiro (TAIB), no bairro do Bom Retiro, que chegou a promover uma campanha de revitalização em muito semelhante a que está sendo empreendida em prol do TBC hoje.

Liderada pelo então diretor do Instituto Cultural Israelita Brasileiro, Benjamin Seroussi, ela quer resgatar um teatro histórico projetado por Jorge Wilhem no subsolo do prédio conhecido como Casa do Povo, no Bom Retiro. A campanha por sua reativação indiretamente contou com a promoção de uma peça, "Bom Retiro 958 Metros", do grupo Teatro da Vertigem, que em 2012 adentrou as instalações ao final de seu cortejo pelo bairro para mostrar as instalações quebradas e cadeiras retiradas do piso dentro do teatro que ficou dez anos sem ser aberto antes da cessão para a realização da peça.

A campanha acabou estagnada sem que angariasse apoios na esfera pública ou entre empresários interessados em revitalizar o local. Alem deste, há tambem o caso do Teatro Cultura Artística, inaugurado quase junto ao TBC, em 1950, e que sofreu um incêndio que destruiu toda a estrutura do teatro em 2008, restando quase intacta apenas a fachada com um afresco de Di Cavalcanti, deixado ali desde sua inauguração. Sua reforma, que previa abertura para gêneros mais populares como os musicais ${ }^{311}$, está andando lentamente desde 2008. O questionamento se dá pelos entes envolvidos na gestão do prédio, a Sociedade de Cultura Artística e o Governo do Estado, não se acertarem quanto à responsabilidade de cada parte no processo, e por alegações de que o arquiteto Paulo Bruna, contratado para a obra, não teria respeitado o tombamento do edifício. Portanto, tal como o TBC, o problema para a paralisia nas atividades se dá por uma confusão entre diferentes instâncias de gestão.

311 "Novo Cultura Artística terá palco para musicais", in: Folha de S. Paulo, 08 de maio de 2013, em: <https://www1.folha.uol.com.br/ilustrada/2013/05/1274702-novo-teatro-cultura-artistica-tera-palcopara-musicais.shtml> Acessado em 18 de agosto de 2019 
No âmbito nacional, um bom exemplo a ser mobilizado é o Teatro Nacional Claudio Santoro, em Brasília, que está passando desde outubro de 2017 pelo mesmo processo de tentativa de concessão de bem público para o setor privado que se intentou fazer com o $\mathrm{TBC}^{312}$. A base para ambas as operações seria o Marco Regulatório das Organizações da Sociedade Civil, uma lei federal aprovada em 2014 que diz que o Estado pode procurar entidades especializadas em recuperação de patrimônio cultural habilitadas a captar recursos privados por meio da Lei Rouanet, alegadamente sem impacto para os cofres públicos. O edital foi nomeado como Parceria Público-Privada (PPP), considerado como tal porinterpretação do seu artigo $2^{\circ}$ que prevê participaçãode servidor concursado em comissões de seleção de projetos na instituição.

Alem disso, há algumas diferenças sutis e importantes deste quanto ao processo envolvendo o TBC. A primeira é de, neste caso, houve o anúncio de abertura de um edital público para tal, ainda que de maneira simbólica quando da cerimônia montada para fazer esse anúncio. A segunda questão é que o governo diz ter tido a intenção de convocar a sociedade civil a participar do processo ao dizer que a participação é benvinda à iniciativa privada, pois teoricamente apenas pessoas jurídicas poderiam entrar nessa concorrência e arcar com as necessidades operacionais e o término de uma possível reforma a ser feita no prédio que também se encontra fechado.

Neste caso do TBC, desde 2013 ele está em reforma; sendo que o fracionamento da obra levanta dúvidas sobre qual o orçamento final para sua conclusão e quanto foi efetivamente gasto até aqui - houve previsões nesse sentido entre trinta e cinco e trinta e oito milhões de reais, com apenas de uma das quatro salas do local com obra finalizada, com as outras salas tendo obras iniciadas apenas posteriormente à conclusão da etapa anterior, o que faz com que não se preveja também quando ela seria terminada. Em uma hipotética entrada da associação na negociação pela concessão do Teatro Nacional, o fato de que a mesma tem a previsão de poder se tornar uma Organização Social (OS) modelo esse em voga dentro das administrações públicas na área de cultura - não impediria de entrar nessa concorrência, ainda que o termo "Organização da Sociedade Civil" possa ser um sinônimo de ONG.

\footnotetext{
312 "Governo procura parceiro na iniciativa privada para reformar Teatro Nacional", in: Agência Brasília, 19 de outubro de 2017, Disponível em: <https://www.agenciabrasilia.df.gov.br/2017/10/19/governoprocura-parceiro-na-iniciativa-privada-para-reformar-teatro-nacional/> Acessado em 18 de agosto de 2019
} 
A questão é que ambas são constituídas como entidades sem fins econômicos, conforme a ATBC se denomina. Nesse sentido, a diferença é que a OS é designada diretamente pelo poder Executivo de plantão, ou seja, não precisaria chamar por uma concorrência pública $^{313}$. O caso da concorrência aberta pelo ministro Sá Leitão para o TBC poderia se encaixar nesse tipo de chamada, pois o anúncio de sua concessão foi feito diretamente por ele, e não pelo presidente da FUNARTE, administradora direta do teatro. A partir da questão de como se dão essas e outras concorrências públicas, a maneira como a ATBC se coloca como sua razão social a faria assim estar apta a entrar nessa concorrência, pois seu Estatuto Social prevê que:

No desenvolvimento de suas atividades, a ATBC poderá firmar convênios, contratos de gestão, termos de parceria, termos de fomento, contratos públicos e privados e estabelecer intercâmbios, promovendo iniciativas conjuntas com outras instituições públicas elou privadas, nacionais e internacionais, [...]Poderá, ainda, obter qualificação como Organização Social em âmbito federal, estadual elou municipal, observando-se as disposições deste estatuto, bem como a legislação aplicável. ${ }^{314}$

Alem disso, o modo administrativo da associação enfrenta a questão de não ter patrocinadores definidos, diferente de quando foi fundada a SBC, que nos anos 1940 simbolizou o início da concretização dos esforços em prol do estabelecimento do TBC ao arregimentar muitos empresários proeminentes da primeira metade do século $\mathrm{XX}$ como "mecenas" associados ao prédio, que então passou a administrar o teatro após sua inauguração.

Outra questão envolvendo a ATBC e as confusões entre atuação no setor público e privado é que o projeto original previa interligação, ainda que simbolizada por uma mera queda de muros, do prédio original do TBC com a Casa de Dona Yayá, prédio histórico da Bela Vista que hoje é um Centro de Preservação Cultural da USP - ou seja, um órgão público, o que causaria mais um conflito de atribuições em uma possível negociação pós-reabertura do teatro - e a ligação afetiva que o TBC também tem com o Teatro Oficina, que está à vista do TBC.

\footnotetext{
${ }^{313}$ Para saber mais sobre as possibilidades de ação de Organizações Sociais na Cultura, Cf. em: PONTE, Elisabeth. Organizações sociais, OSCIPs e a Gestão Pública Não-Estatal na Área da Cultura. São Paulo: Itaú Cultural/Iluminuras, 2012.

${ }^{314}$ ESTATUTO SOCIAL ATBC, Art. 5
} 
O projeto de reforma prevê inclusive uma passarela para ligar o terreno do TBC ao que está ao lado do Oficina, e enfrenta um sério entrave com o Grupo Sílvio Santos, dono de vários prédios e terrenos no bairro e no caminho entre os dois teatros, inclusive do terreno vazio ao lado do Oficina reivincado pela comunidade do bairro para se tornar uma área pública. Silvio Santos, no entanto, parece estar se tornando cada vez mais irredutível na sua intenção de concretizar os planos que tem para a região. Em contraponto a isso, a ATBC contribuiu na organização junto do Teatro Oficina de um grande cortejo que reproduzia o evento de junho de 2011, reunindo mil e quinhentas pessoas a caminhar pelo bairro da Bela Vista no dia 25 de novembro de $2017^{315}$, em um momento onde se chegou a evocar a cena da peça “Cacilda!” encenada em 2011.
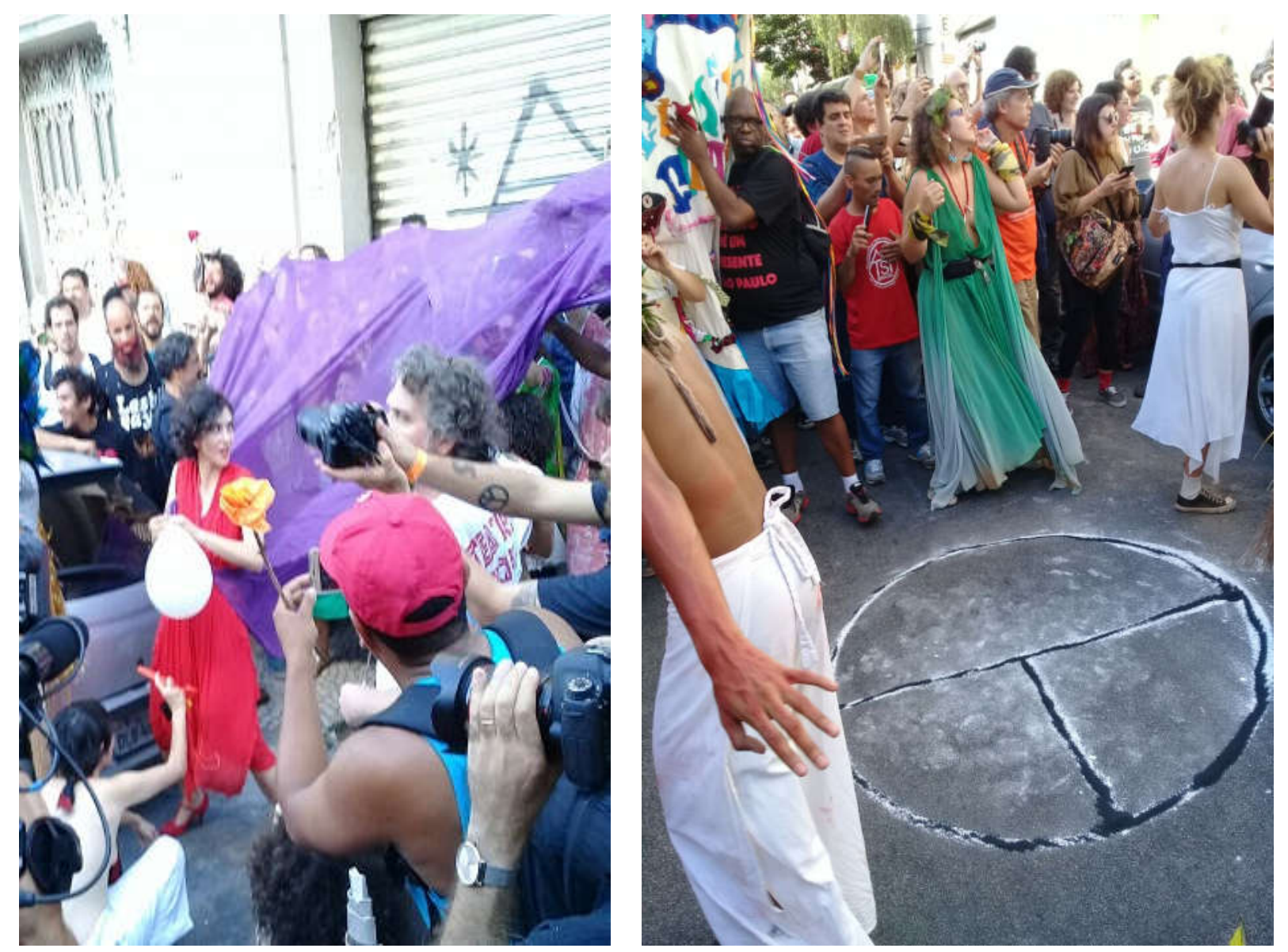

Imagem 27 - Ato do Teatro Oficina em 25 de novembro de 2017, com a encenação da cena de "Cacilda!" em frente ao TBC e o logo original do TBC reproduzido na rua Major Diogo.

\footnotetext{
315 "Convocado pelo Teatro Oficina, ato faz 'abraçaço' contra torres no Bexiga", in: Folha de S. Paulo, 26 de novembro de 2017, Disponível em: <https://www1.folha.uol.com.br/ilustrada/2017/11/1938429abracaco-reune-1500-pessoas-no-bexiga-em-defesa-do-teatro-oficina.shtml> Acessado em 18 de agosto de 2019
} 
Mesmo com esse apoio explícito da opinião pública, a situação rapidamente se deteriorou, com a reversão de decisões feitas em órgãos de proteção do patrimônio - o CONPRESP, municipal, e o CONDEPHAAT, estadual - que protegiam o entorno do teatro desde $1983^{316}$ mas foram derrubadas no primeiro semestre de 2018. Tais negociações falhas envolvendo órgãos públicos que parecem defender bens privados, colocando-se a questão de que o próprio CONDEPHAAT reconhece o Oficina como bem público ${ }^{317}$, escancaram as confusões que muitas vezes são feitas entre as instâncias públicas e privadas para que a interpretação das leis se faça a partir de conveniências alheias ao controle social.

Esse acirramento da luta pela ocupação público-privada do bairro da Bela Vista em terreno em torno do Teatro Oficina, marcado para ser o Parque do Bixiga por projeto de lei a ser apreciado na Câmara Municipal, é o dado mais forte e simbólico a respeito dos embates e confusões que foram ilustradas aqui onde a cultura, e o teatro em particular, busca seu papel na sociedade de forma a ter um impacto verdadeiro na formação de um país que ainda parece marginalizar a importância da arte para a construção de uma comunidade minimamente mais justa.

É neste sentido que o fortalecimento de políticas culturais coloca-se como pauta prioritária para todas as instâncias coletadas, e que tais políticas possibilitem o estímulo do pensamento crítico em toda a sociedade. Mesmo com esses últimos reveses, após a efeméride dos setenta anos de abertura do teatro em outubro de 2018, a ATBC teve um ano agitado em 2019 na lembrança desse momento histórico, com seus primeiros trabalhos de produção teatral realizados na Biblioteca Mário de Andrade - local simbólico da inauguração da EAD, que desde 1968 é vinculada à USP - e no TUSP na Rua Maria Antônia, câmpus de humanidades da USP até a Batalha de $1968^{318}$.

\footnotetext{
${ }^{316}$ A decisão no CONDEPHAAT é de 1983, quando Aziz Ab'Saber era presidente do órgão estadual, e suas normas prevêem proteção contra novas construções a 300 metros do bem tombado; a decisão no âmbito municipal, no CONPRESP, se deu em 1991.

${ }^{317}$ Carta do presidente do CONDEPHAAT a respeito da decisão do órgão: "Cabe lembrar, por fim, que para o CONDEPHAAT não existe o instituto do destombamento. Dessa forma, o Teatro Oficina permanece tombado e não poderá ser demolido. Acresce o fato de que o Teatro Oficina não poder mais ser vendido a ninguém, por ser um espaço público."; apud BARRETO, Luisa. "Teatro Oficina: destombando o Tombamento". In: Outras Palavras, 01 de outubro de 2018 Disponível em: $<$ https://outraspalavras.net/cidadesemtranse/teatro-oficina-destombando-o-tombamento/> Acessado em 18 de agosto de 2019

${ }^{318}$ A Batalha da Maria Antônia foi um confronto entre estudantes da USP e do Mackenzie, na época dividindo a mesma rua na Vila Buarque em São Paulo. A partir do Mackenzie, membros do CCC e da Polícia acirraram os enfrentamentos, que resultaram na morte do estudante José Guimarães. Em 2019,
} 
A Biblioteca Mário de Andrade abrigou atividades da ATBC desde o início da constituição jurídica da associação. O marco do primeiro evento foi o Seminário "TBC - História e Permanência de um Marco do Teatro Moderno Brasileiro" realizado no seu Auditório nos dias 23 e 30 de maio de 2018, com a presença dos professores da USP Elisabete Azevedo e Ferdinando Martins; e da diretora da Faculdade de Filosofia, Letras e Ciências Humanas, Maria Arminda do Nascimento Arruda, para falar de sua pesquisa sobre o contexto cultural que deu início à companhia. O seminário também teve as presenças honrosas de Maria Thereza Vargas, secretária de Cacilda Becker e ativa pesquisadora da história do teatro brasileiro; Jefferson Del Rios, jornalista e crítico de arte; e Célia Gouvêa, última esposa de Maurice Vaneau e dona do Acervo GouvêaVaneau, que mantém o legado de seu falecido marido e de sua trajetória de sucesso na dança paulista.

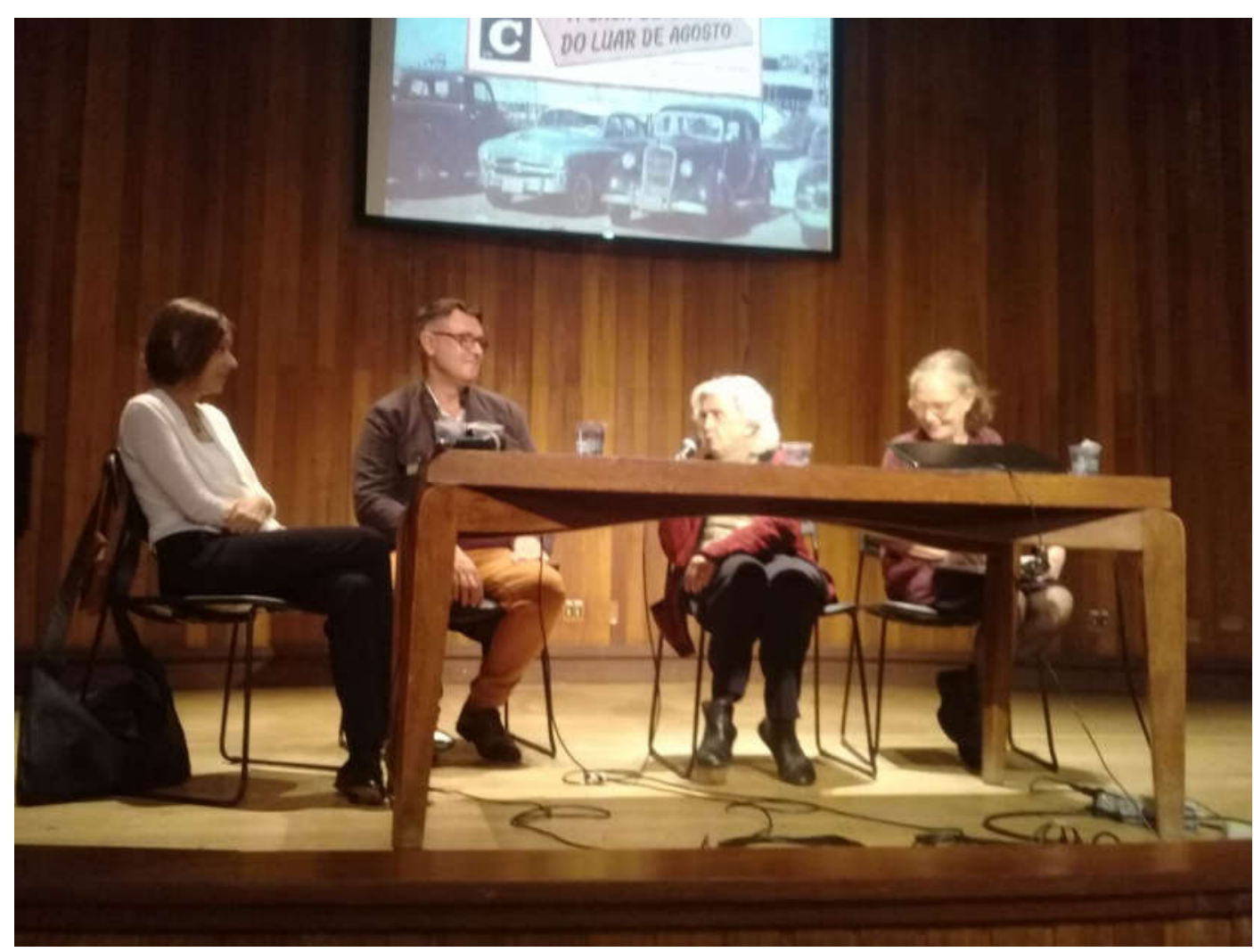

Imagem 28 - Seminário TBC na Biblioteca Mário de Andrade em maio de 2018. Na foto, os professores da USP Elisabete Azevedo e Ferdinando Martins; a pesquisadora Maria Thereza Vargas; e a dançarina Célia Gouvêa, do Acervo Gouvêa-Vaneau.

sua morte foi reconhecida pela Comissão da Verdade da Assembléia Legislativa do Estado de São Paulo como provocada por agentes do Estado brasileiro, que atiraram sobre ele a partir do Mackenzie. 
Quanto aos eventos de 2019, foram realizadas as dramatizações de "Volpone", com a Bendita Trupe; "A Semente", com a Companhia Livre, tendo como convidados da diretora Cibele Forjaz artistas como Celso Frateschi, Denise Fraga e Élcio Nogueira Seixas; e uma aula pública com trechos da peça "Galileu Galilei", de Bertolt Brecht, encenada por Denise Fraga e dirigida por Cibele Forjaz.

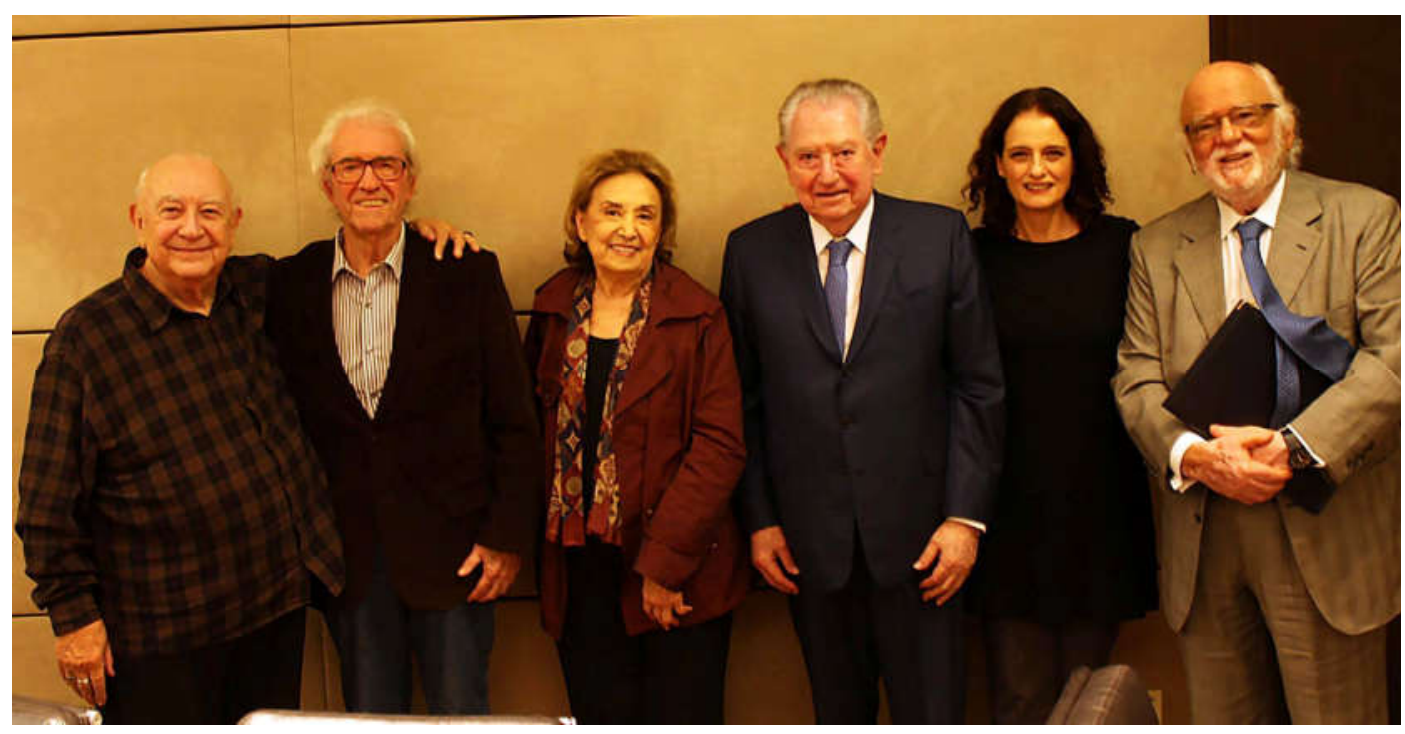

Imagem 29 - Reunião para tratativas com SESC e FECOMERCIO pela reabertura do TBC, em março de 2019; da esquerda para a direita: Sergio Mamberti, Juca de Oliveira, Eva Wilma, Abram Szajman, Denise Fraga e Danilo Santos de Miranda. Foto: Álvaro Machado

Também em 2019, no dia 21 de março, foi feito chamamento pela abertura de negociações com a administração do Serviço Social do Comércio (SESC) e da Federação do Comércio de Bens, Serviços e Turismo do Estado de São Paulo (FECOMERCIO) para uma proposta de administração conjunta do TBC, de modo a dar liberdade para os artistas que esperam poder voltar a se expressar artisticamente naquele local. Participaram da reunião os associados honorários Sergio Mamberti e Denise Fraga; o presidente da ATBC, Álvaro Machado; Abram Szajman, presidente da FECOMERCIO, entidade que congrega os sindicatos patronais do setor terciário da economia, à qual congrega o SESC; o diretor do SESC São Paulo, Danilo Santos de Miranda; e os atores Juca de Oliveira e Eva Wilma, remanescentes da geração dos anos 1950, que formou as companhias que serviram de base para o teatro brasileiro de hoje.

As conversas com o SESC e a FECOMERCIO serviram para estreitar laçõs da associação com essas entidades, que tinham tratativas abertas com as devidas instâncias federais (MinC e FUNARTE) a quem o TBC está hoje submetido. Reportagem do 
jornal O Estado de S. Paulo registra conversas nesse sentido ao menos desde 2017, sob a gestão de Roberto Freire, ex-diretor do TBC quando do período de intervenção da CET, no Ministério da Cultura. Uma questão é que desde o início de 2019, o MinC não existe mais enquanto ministério único, incorporado ao dito Ministério da Cidadania, ficando o setor cultural sem setor próprio no governo pela primeira vez desde a democratização do país em 1985, causando incertezas quanto aos compromissos e negociações para efetivação do projeto de reforma e reabertura do teatro.

Em meio a isso, a ATBC, mais que o apoio expresso nas reivindicações da associação em prol do teatro paulistano e brasileiro, recebeu seu maior reconhecimento dentro da cena teatral, com o prêmio entregue pela APCA em 17 de junho de 2019, pelos esforços na preservação da memória do TBC neste ano em que se completam setenta anos de sua inauguração. Desse modo, os envolvidos na luta esperam que o esforço empreendido na preservação e continuidade deste teatro, razão primeira para o surgimento do movimento, não se torne algo vão e perdido. Pela história a ser levada em conta nesse espaço, e pelas possibilidades de futuro para o teatro paulista e brasileiro contidas no TBC, traduzidas na expectativa de todos de que o que foi feito até aqui possa dar os devidos frutos pelo crescimento e solidificação da cultura teatral entre nós.

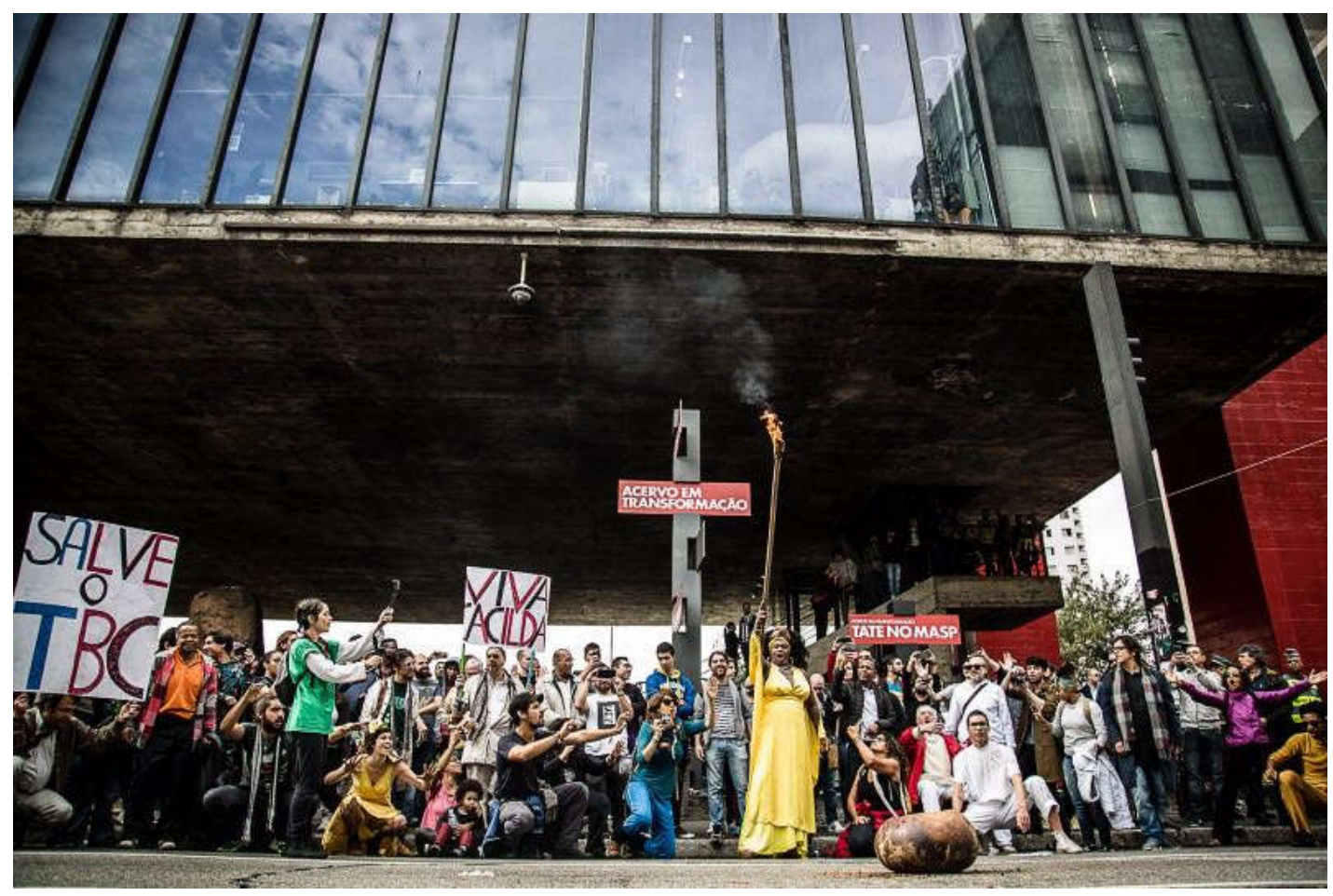

Imagem 30 - Marcha do Teatro Oficina pelo Parque do Bixiga, em 5 de agosto de 2018, com saída em frente ao MASP (projetado por Lina Bo Bardi, que fez também o projeto do Oficina). Foto: Igor Marotti 


\section{CAPÍTULO 4: A parte que cabe ao teatro}

\subsection{Outros Modos de Produção da Cena Teatral Paulistana}

O papel de entidades empresariais e patronais no teatro se fazia presente desde os primórdios da atividade teatral no pais, quando mecenas investiam na construção, compra e aluguel de edifícios teatrais e na consolidação de companhias; Esse dado é essencial para se entender a construção e evolução do teatro brasileiro. O TBC deixou isso explícito ao se cercar de uma entidade gestora própria formada por empresários investidores que levaram o teatro a um nível mais elevado em sua atuação e produção. Em um ambiente de expansão da variedade das atividades econômicas, como foram os anos 1950, instituições consolidadas tambem passaram a investir em projetos próprios, notadamenteem iniciativas de investimento em cultura.

Desde o início dos anos 1950, havia uma intenção das entidades representativas da indústria e comércio em tomar parte do crescimento da cena teatral na cidade. Como resultado da consolidação dessas iniciativas surgiram em 1963 o Teatro Popular do SESI - construído junto à sede da entidade na Avenida Paulista com o grupo de Teatro Experimental formada por Osmar Rodriguez Cruz como sua companhia residente, tornada profissional após a abertura do teatro -, e em 1967 o Teatro Anchieta, do SESC, construído em seu centro social na Consolação para, a princípio, abrigar obras experimentais que poderiam ter dificuldade de atingir salas de teatro estabelecidas ${ }^{319}$.

O SESC é uma instituição de caráter privado, fundada em 1946 e mantida pelos empresários do setor comercial, de bens e serviços que tem por objetivo proporcionar qualidade de vida e atividades culturais para os trabalhadores do setor. Seu caráter de atuação social fez com que ao passar dos anos suas ações chegassem a mais pessoas além daquelas inicialmente planejadas para serem atingidas. Suas quartenta e três unidades no estado de São Paulo contam com espaços para atividades teatrais, e algumas tem salas especialmente para este fim, como é o caso do Teatro Anchieta, localizando na unidade Consolação na Rua Dr. Vila Nova (Vila Buarque, próximo ao antigo Teatro Leopoldo Fróes) e que abriga a maioria dos projetos especiais de teatro da instituição.

${ }^{319}$ MATE, 2017, p. 31 
Duas questões foram prementes desde o início do projeto do SESC Anchieta. Uma delas foi a implementação do programa Escola Vai ao Teatro, coordenado por Miroel Silveira, que buscava fazer do teatro um local de referência para a integração do teatro com a educação. Dessa forma, os estudantes de teatro se sentiam mais à vontade para trabalhar com os conceitos de autores de todas as épocas e gêneros. Outro destaque inicial era em relação ao preço dos ingressos, sempre subsidiados pela entidade para se tornarem acessíveis à maior parte da população. Colocando o SESC como uma entidade que não visaria o lucro, Cleyde Yáconis se espanta ao comentar sobre o projeto teatral do SESC com a maneira como a instituição trabalha a questão da democratização do acesso, permitindo o acesso à linguagem teatral mantendo inclusive a qualidade em sua produção e manutenção. Tudo isso cobrando um preço baixo por esse acesso, como nenhum teatro ou rede parecia fazer, pelo fato de Yáconis considerar o ingresso de teatro como algo “(...) naturalmente caro, restrito a uma classe abastada",320.

Essa prática colocada pelo SESC em toda a sua rede é realmente um diferencial. A sua atitude, e tambem a iniciativa do SESI em não cobrar entrada em seu teatro, pode ser explicada pelos subsídios colocados pela entidade em seus gastos. Dentro das contribuições que recebe dos associados e trabalhadores dos ramos por eles cobertos ${ }^{321}$ - comércio e serviços, no SESC, e indústria, no SESI -, um percentual desse orçamento é destinado a manter preços baixos nos ingressos, possibilitando a diferentes classes excluídas acesso ao ato de assistir teatro.

A questão, entretanto, de apenas baixar o preço dos ingressos esperando que o povo que não assista ao teatro cotidianamente possa ir atrás dele se bate contra noções arraigadas do próprio período onde tal política foi pensada. Era preciso que isso estivesse aliado a uma estratégia para sair de uma lógica passiva, de apenas oferecer o que considerava ser "o melhor" em termos culturais, esperando que as pessoas por si só acompanhassem a ideia inicial. Para evitar esse tipo de postura, é como se desde o início de suas atividades, a entidade buscasse aliar conceitos de André Malraux para dar vazão

\footnotetext{
${ }^{320}$ Entrevista a José Menezes Neto, in: MATE, 2017, p. 32

${ }^{321}$ O Decreto Lei no 9.853 de 13 de setembro de 1946 ampara as contribuições dos comerciários ao SESC. No seu art. 30 consta que: "Os estabelecimentos comerciais enquadrados nas entidades sindicais subordinadas à Confederação Nacional do Comércio (art. 577 da Consolidação das Leis do Trabalho, aprovado pelo Decreto $\mathrm{n}$ - 5.452, de 10 de maio de 1943), e os demais empregadores que possuam empregados segurados no Instituto de Aposentadoria e Pensões dos Comerciários serão obrigados ao pagamento de uma contribuição mensal ao Serviço Social do Comércio, para custeio de seus encargos".
} 
às necessidades de formação, produção e exibição de conteúdos, no caso teatrais, que condicionariam uma boa experiência e portanto assimilação de novos conceitos culturais. Esse pensamento foi resumido por Malraux no conceito de ação cultural, partindo além de uma recepção pura e simples, e desse modo fazendo com que o que fosse passado pela experiência cultural permanecesse naquele que a vivenciou, de modo tão ou mais forte em si que o conteúdo educacional.

O decreto que instituiu o Ministério doa Assuntos Culturais da França em 1949 falava explicitamente em “(...) tornar acessível as obras capitais da humanidade (e) assegurar o mais vasto público ao patrimônio cultural" (URFALINO, 2015, p. 44). Porém, o próprio conceito do que seria considerado "obra capital" precisaria ser posto em discussão. Não que a excelência não deva ser um conceito a ser apreciado, mas o ponto da real democratização do acesso, a partir da descentralização e deshierarquização dos centros culturais, é o que precisa ser atingido, especialmente em sociedades carentes desse tipo de ação cultural como a brasileira.

Ao perceber as armadilhas no discurso dessa pretensa excelência, Malraux fez tempos depois em 1966 uma paráfrase um tanto perigosa com discursos totalitários, ao dizer que “(...) a cultura será popular ou não será” (apud URFALINO, Op. Cit., p. 46). Apesar de Malraux defender que haveria por parte do Ministério a valorização de aspectos mais singulares e particulares (a "cultura para cada um" contrastando com "a cultura para todos"), esse discurso parecia também dissociar "popularização" da real cultura popular, ao deixar de lado aspectos desta última em favor de uma arte escolhida por intelectuais ou entidades como passível de ser partilhada e de criar engajamento no seu público.

Vale ressaltar que aqui "público" não deve também ser visto de uma maneira uniforme, pois assim como a diversidade cultural abarca as diferentes expressões, é algo a ser considerado quando se fala dos diversos tipos de público a serem atingidos pelas experiências culturais. Quanto à "experiência", deve-se falar tanto da cultura que se assiste como daquela com a qual se trabalha através de cursos e oficinas de formação rápida ou contínua, para que cada pessoa possa ter a possibilidade de criar uma expressão própria. Sobre isso, Isaura Botelho (2009) pontua de forma bastante incisiva: 
Desta forma, chegou-se a um novo paradigma: são as políticas que têm como foco a democracia cultural, que ao contrário da anterior, têm por princípio favorecer a expressão da diversidade cultural. Ao invés de concentrar todo o esforço na condução de todos às mesmas fontes (museus, concertos, por exemplo), ela deve fornecer aos diversos segmentos da população os meios de desenvolvimento de expressões que, dialogando ou não, com a cultura tradicional, estejam em sintonia com suas próprias necessidades e exigências. A democracia cultural pressupõe a existência não de um público único e uniforme, mas de vários públicos, no plural, com suas necessidades, suas aspirações próprias e seus modos particulares de consumo e fruição. Nesta nova perspectiva abandona-se uma visão unidirecional, terreno de certezas, onde se sabia que cultura deveria ser privilegiada, assumindo o universo da diversidade cultural, isto tanto no fazer quanto na recepção deste fazer. ${ }^{322}$

O projeto cultural do SESC, construído paulatinamente no decorrer do tempo, sempre pareceu estruturar-se no sentido de atender essas diversas demandas. Ainda que não de maneira universalizante, mas posteriormente a ponto de suas unidades serem chamadas de "centros comunitários" por órgãos oficiais pelo entendimento e percepção da excelência que sua atuação pública tem perante o público geral, a entidade segue buscando parcerias com empresas para realização de suas atividades. A maior parte dessas parcerias se dá com entidades dos mais diferentes segmentos públicos e privados, como institutos e fundações, ONGs, órgãos diplomáticos e de promoção cultural, entre outros $^{323}$.

Isso aparecia de modo semelhante durante a gestão de mais de trinta anos de Osmar Rodriguez Cruz no SESI. Ele e seu grupo chegaram a fazer uma parceria com uma empresa de Santo André, a Rhodia, com quem havia desenvolvido seu primeiro trabalho de formação antes de assumir sua função no SESI. Esse projeto atuou por duas temporadas no TBC entre 1974 e 1976 - uma remontagem de "Leonor de Mendonça", de Gonçalves Dias, peça que estava no repertório da companhia do TBC desde os anos 1950, e "O Noviço", de Martins Pena. Para o dramaturgo Antonio Bivar, essa tendência

\footnotetext{
322 BOTELHO, Isaura. Democratização Cultural: Desdobramentos de uma Ideia. In: blog Colcha de Retalhos. 14 de janeiro de 2009. Disponível em:

$<$ https://colchaderetalhosaldaiza.wordpress.com/2009/01/14/democratizacao-culturaldesdobramentos-de-uma-ideia/> Acessado em 18 de agosto de 2019

${ }^{323}$ Hoje, a desproporção entre entidades estrangeiras e brasileiras com parcerias ativas de apoio ao SESC é flagrante: são onze do Brasil contra setenta e duas do exterior, muitas delas com atuação própria no país.
} 
em prol dos textos clássicos não era algo refratado pelo público, apenas atendia à demanda de um público que buscava “(...) uma estética extremamente clean e familiar, (pois) as montagens de Osmar Rodrigues Cruz no Teatro Popular do SESI eram, ao contrário (da estética de vanguarda da época), extermamente formais, feitas quase à maneira da época em que haviam sido escritas",324.

Em paralelo a essa tendência algo popular de promoção cultural da entidade patronal da indústria, o SESC ampliou seu leque de iniciativas promovendo ações que iam além de seus espaços físicos. No campo da produção, havia o incentivo à produção de espetáculos brasileiros em festivais internacionais, e o acolhimento à proposta dos Festivais Internacionais de Artes Cênicas de Ruth Escobar entre 1976 e $1981^{325}$ assentou-se perfeitamente nessa vontade, pois o propósito maior de Escobar com o festival era não apenas trazer companhias estrangeiras, mas estimular a teatralidade local através de vários meios, inclusive práticos por meio de workshops e oficinas com alunos de teatro.

Na parte formativa, Antunes Filho mostrava um maior desenvolvimento do seu trabalho com jovens no sentido de colocá-los não apenas como executores da proposta de um diretor, mas como co-criadores. Seu grupo Macunaíma, nomeado assim pela primeira montagem do grupo para o clássico homônimo de Mário de Andrade ${ }^{326}$, formalmente era uma cooperativa, dentro do espírito dos novos grupos experimentais de criação coletiva em voga nos anos 1970. Antunes Filho foi então convidado a trabalhar no SESC, em um projeto que seria o primeiro de uma companhia residente na entidade.

A comissão encarregada de analisar o convite para Antunes considerava que, de certa forma, o modelo cooperativado de teatro trazia problemas próprios de organização (MATE, 2017, p. 102), ainda que a CPT tivesse sido criada há pouco exatamente para dar um amparo a esses grupos. Com isso, após Antunes Filho ser contratado em 1982, ele levou seu grupo ao Teatro Anchieta para montar uma companhia de repertório e pesquisa experimental, com o nome de Centro de Pesquisa Teatral, curiosamente utilizando a mesma sigla da entidade de apoio à classe.

\footnotetext{
324 MACHADO, 2004, p. 45

${ }^{325}$ A parceria entre SESC e Ruth Escobar pela produção e realização do festival se repetiu de 1995 e 1999, com espetáculos em São Paulo e outras cidades do estado. in: MATE, 2017, p. 42-6

${ }^{326}$ Formado em 1977, o grupo também tinha em repertório "Nelson Rodrigues: O eterno Retorno", junção de quatro peças do autor; in: MATE, Op.Cit., p. 101
} 
Por não ter tido ainda essa experiência em lidar com modo de produção diversos antes de efetivar Antunes como parte da sua estrutura, a direção do SESC tomou uma decisão ousada para seus parâmetros na sua contratação, ao liderar estudos de viabilização dos métodos de trabalho do diretor e a possibilidade de adequação à implementação de uma lógica de resultados mais próxima à de uma empresa. Logicamente, essa adequação também passaria pela afinidade de conceitos buscados por ambos, e nisso a concordância era mais evidente, por ambos quererem discutir a produção brasileira sob um ponto de vista de formação e estudo dos ofícios do teatro (parte técnica e artística). Assim, formou-se o método de trabalho que permaneceu por mais tempo em funcionamento numa entidade privada.

Esse tipo de reconhecimento oficial era também o que buscavam outros grupos cooperativados surgidos pelos anos 1980 e 1990. Nesse período, muitos grupos dos anos 1970 que permaneceram ativos pareciam ter conquistado alguma estabilidade no seu modo de produção, ainda que não pudessem ter chegado ao nível de segurança institucional de Antunes Filho. O conceito sobre o qual se classificaram, nesse ponto de suas trajetórias, designou-se de "coletivo", algo além do conceito anterior de companhia ou teatro de grupo. Ainda que a história do teatro em geral remonte desde seu surgimento a uma esfera coletiva, e que o modo de estruturação surgido nesse contexto fosse um desdobramento do sistema cooperativado no qual muitos deles funcionavam, este conceito se diferencia por já ser utilizado nas artes plásticas para designar agrupamentos que “(,,) se reúnem com o intuito de ocupar determinados espaços ou discutir determinados temas de interesse comum, 327.

Desse modo, os coletivos que se articularam no movimento Arte Contra a Barbárie a partir de 1998 basicamente se encaixavam nessa classificação, por se organizarem de modo a valorizarem a pesquisa interna em um local específico de reunião, conhecido pelo público e pelos artistas identificados com tal proposta. Nesse movimento, eles se organizaram de forma a construir um pensamento estruturado a respeito de uma proposta de nova legislação, fazendo estudos relacionados ao modo de trabalho dos que se reuniam em torno desse objetivo, e lançando a semente do programa que viria a se tornar a Lei de Fomento da Cidade em 2002.

${ }^{327}$ VELOSO, 2009, p. 3 
Uma vez implementado como Lei Municipal 13.279, de 8 de janeiro de 2002, o . Mapeamento realizado por Dorberto Carvalho e Iná Camargo Costa ${ }^{328}$ nos cinco primeiros anos de vigência da lei mostrou que o movimento acarretou em um aumento significativo de coletivos jovens em diferentes regiões da cidade pelas melhores condições para sua atuação, além de aumentar o engajamento desses e dos demais grupos quanto à sua organização coletiva, pela criação e manutenção de diversos minifóruns para discussão das diversas necessidades de cada localidade. Porém, o número de grupos pleiteantes chegou a quinhentos em uma das edições, criando problemas para as comissões avaliadoras entre priorizar núcleos mais "tradicionais" ou os que estavam florescendo.

Enquanto núcleos "tradicionais", considerados assim por estarem entre os que primeiro adentraram ao movimento Arte Contra a Barbárie, seguiam rotas mais ou menos coincidentes com o Fomento - pelo fato de uns entre eles serem contemplados mais vezes do que outros -, havia também quem passava por uma espécie de limbo até alcançar seus efeitos. Como exemplo ilustrativo dos percalços para o Fomento atingir totalmente seus objetivos, serão destacadas experiências quando da montagem em 1999 de "A Filosofia na Alcova", do Marquês de Sade, em versão realizada por Marcelo Marcus Fonseca enquanto seu grupo, o Teatro do Incêndio, atravessava uma fase de transição ${ }^{329}$; e Mundana Companhia, na montagem de "Na Selva das Cidades", de Bertolt Brecht, em 2016. Ambas trabalharam com meios diferentes de subvenção, uma sem apoio do Fomento e outra através do mesmo em conjunto com outras fontes.

No caso da montagem de Fonseca, o caminho descrito para a efetivação da encenação foi extremamente tortuoso desde seu início, mesmo passando por várias avaliações dentro de diversas instâncias governamentais. Inicialmente, o projeto havia sido apresentado ao então secretário adjunto da Secretaria de Cultura Municipal, que respondeu que “(...) Marquês de Sade (seria), dentre tudo o que seria "impatrocinável” (sic), o que estaria no topo" ${ }^{, 330}$.

\footnotetext{
${ }^{328}$ apud BETTI, in: DESGRANGES; LEPIQUE, 2012, p. 121

329 Fonseca havia fundado o grupo Teatro aos Tragos, com o qual realizou montagens como a de "O Balcão", de Jean Genet - em cartaz no TBC -, e "Baal", de Bertolt Brecht, durante os anos 1990. Com a dissolução do núcleo original, ele encampou esta peça de Sade junto a Cibele Forjaz na Funarte e no Oficina, numa formação "embrionária" do Teatro do Incêndio, ativo até hoje. In: FONSECA, 2018, p. 33 ${ }^{330}$ FONSECA, Op. Cit., 2018, p. 34
} 
A partir desses questionamentos, o projeto recebeu apoio de Antonio Carlos de Moraes Sartini, então assessor do Departamento de Formação Cultural da Secretaria estadual, onde foi inicialmente acolhido. Entre a análise e a decisão sobre a efetivação do apoio, houve um trabalho árduo para mostrar a importância e a atualidade da proposta. Por fim, com a proposta finalmente aceita, o grupo angariado por Fonseca se reuniu em torno do projeto com muito ardor e criatividade, como descrito abaixo:

Com o aval da secretaria (para "A Filosofia na Alcova”) o grupo promoveu mesas filosóficas sobre a obra do Marquês de Sade e uma leitura encenada da peça. [...] A primeira mesa de debates, a segunda [...]. Com o apoio para o evento, a peça foi montada em 40 dias [...] do periodo de estudos, palestras, leitura pública, debates até a conclusão das temporadas, em um projeto de quase 10 meses de duração, o grupo sentiu o início do que seria a estrutura para o coletivo, entendendo que o trabalho tinha continuidade e buscava perspectivas: seu desejo de treinamento, de um planejamento futuro, de uma identidade a partir do que se vinha fazendo e de se rever constantemente, foi um passo natural. ${ }^{331}$

No caso da Mundana Companhia, a preparação foi em certos pontos parecida à da montagem de Fonseca, com as fases de pesquisa e definição do escopo da criação como algo definido coletivamente, à revelia da obtenção do financiamento. Nesse caso, durante a fase de pesquisa, o projeto foi apresentado primeiramente ao SESC, de onde obteve um primeiro auxílio com a contrapartida de que se escrevesse um livro sobre a experiência da transposição da pesquisa de campo para a montagem da peça. Os prazos para concretização de todo o processo, com os recursos obtidos, se completaram também de forma semelhante ao que ocorreu na descrição de Fonseca.

Assim, após essa pesquisa inicial, foi possível centrar-se na formação do elenco com vários integrantes agregados à companhia: artistas como Renato Borghi e Laura Vinci, e técnicos nos trabalhos de direção, produção e elementos técnicos, enquanto a pesquisa continuou com "imersões" durante sete meses em doze pontos espalhados por várias regiões da cidade. Laura Vinci destacou também o quanto cada segmento teve a chance de “(...) pensar a organização de seu respectivo quadro, com total liberdade para escolher a localização específica e o enfoque a relação entre a cena e a cidade, além de cuidar da logística, da produção e da qualidade do estímulo criativo"332.

\footnotetext{
${ }^{331}$ FONSECA, 2018, p. 34-5

332 in: MUNDANA COMPANHIA, 2016, p. 14
} 
A descrição desse trabalho, além de mostrar um enfoque bastante profissional de uma companhia (ou "coletivo") que já trabalhava em conjunto ou em paralelo desde a eclosão do movimento Arte Contra a Barbárie, mostra o quanto esperavam fazer deste trabalho um processo contínuo, que cada vez mais abarcasse um caráter de envolvimento do público presente às apresentações. Para eles, era preciso fazer com que a peça fosse além de uma estrutura pública a recebê-la e se apropriasse da dinâmica do grupo para fazer com que os locais escolhidos previamente para as "imersões" fizessem parte da montagem, e não que a montagem se apropriasse deles para seus próprios fins.

Com isso, após uma curta temporada em espaços cênicos do SESC, houve uma primeira tentativa de trazer esse caráter público à tona com apresentações no TUSP ainda no primeiro semestre de 2016, para no ano seguinte o grupo utilizar-se do apoio da Lei de Fomento, tendo sido contemplado para tal em meio ao processo de montagem da peça, para criar uma perspectiva inclusiva onde o trabalho do grupo nos vários entornos escolhidos fosse finalmente realizado nesses lugares, tal como originalmente pensado. E assim se sucederam várias temporadas seguidas, possibilitadas por esse apoio do Fomento, nos bairros da Luz, Guarapiranga, Artur Alvim, Horto, Butantã e Bela Vista durante todo o ano de 2017, com o trabalho sendo cada vez mais reconhecido a ponto de conseguir novos financiamentos em temporadas fora de São Paulo, dando força ao trabalho militante do grupo em prol do teatro.

Sebastião Milaré deu uma boa definição das motivações de grupos como a Mundana, e outros oriundos do movimento Arte Contra a Barbárie, para ocuparem os espaços da cidade e deles fazer uma reapropriação coletiva:

Um teatro que rompe com a própria arquitetura teatral e se estabelece em qualquer espaço, seja um velho armazém, seja a rua ou a praça, sejam albergues de indigentes ou instituições assemelhadas. O espaço não surge do acaso - pelo contrário, o espetáculo foi pensado para ele e o torna uma espécie de protagonista. Não se restringe a ambientar: integra e dá sentido à obra. A ideia é sempre aproximar o espectador da ação dramática e, por vezes, nela o incluir. ${ }^{333}$

${ }^{333}$ MILARÉ, 2010, p. 14 
Esse tipo de postura militante está presente também no teatro de rua e nos coletivos que hoje estão estabelecidos nas periferias das maiores cidades brasileiras onde as temáticas trabalhadas colocam questões sobre direitos humanos e opressão oficial, que dão o tom do trabalho com o teatro nessas comunidades, promovendo-se apresentações na rua ou em sedes próprias.Essas manifestações de rua e de coletivos "periféricos" - ainda que ocupem espaços em regiões mais centrais, como o Teatro União e Olho Vivo, no Bom Retiro - são ainda mais "marginais" do que a ação de grupos independentes estabelecidos em sedes próprias ou outros prédios públicos ou privados.

Enquanto os periféricos optam por esquema de profissionalização próprio, basedo em crowdfunding ou "vaquinhas virtuais" entre o público frequentador, ou se assumem como espaços de formação buscando servir de trampolim para outras atividades, os grupos de ruapodem ser considerados em uma zona cinzenta em relação a como são tratados administrativamente, sem que haja uma definição clara deles como entidades privadas, ou como grupos que necessitam diretamente de algum aporte público para se manterem, sem que precisem se tornar amadores por força, e não por convicção, como o Teatro União e Olho Vivo.

Eles parecem estar ainda mais alijados do que pode ser considerado como o sistema tradicional de fomento teatral, ainda que iniciativas recentes também busquem contemplar esses grupos com uma fatia de seus programas de incentivo, como pode-se atestar pela entrada de grupos como a Brava Companhia, Pombas Urbanas, Paideia e Engenho Teatral, e coletivos semelhantes, dentro do Programa de Fomento de São Paulo para assim "conseguirem encontrar as condições materiais necessárias para uma produção singular e não referendada a padrões convencionais, ampliando a diversidade artística da cidade" ${ }^{„ 34}$. São grupos que buscam ter uma estrutura formal diversa daquelas que tem uma sede fixa para apresentações, pois muitas destas preferem se apresentar em locais alternativos, ou mesmo na rua, criando outros espaços de convívio e de pesquisa. Ainda há certa tensão em abarcar essas possibilidades de expressão dentro das estruturas de apoio teatral existentes.

\footnotetext{
${ }^{334}$ SOLER, Marcelo; SIMÕES, Mônica; ABBUD, Vera. "Doze Anos Feitos de Encontros - A Expansão do Espaço e do Público em Tempos de Lei de Fomento", in: GOMES; MELLO (orgs.), Fomento ao Teatro: 12 anos, São Paulo: Prefeitura, 2014, p.75
} 
Uma situação peculiar em relação a essa relação problemática entre apoio estatal e teatro de rua com viés crítico se deu com a peça "Blitz", da Trupe Olho da Rua, onde após um episódio de coerção policial contra uma exibição da peça em uma praça de Santos, foi questionada a posição do grupo em "criticar a PM" enquanto recebe recursos do Estado, sem que se destaque o fato de que teoricamente não deveriam haver amarras ou mordaças colocadas sobre quem se utiliza de financiamentos públicos em diferentes fazeres artísticos.

A abordagem ao grupo também acabou sendo de uma truculência talvez maior do que a ocorrida contra o Oficina em 1968, pois se eles então eram então dos "elos mais fracos" dentre os passíveis de sofrerem ataque, grupos de rua como a Trupe Olho da Rua são alvo ainda mais fácil, por estarem expostos em local público onde a fronteira entre a encenação e o real está intencionalmente borrada, em que o confronto entre elas também se torna direto. Relato da jornalista Maria Tereza Cruz destaca a estrutura do incentivo público na tentativa de deslegitimar os que criticam quem lhes "patrocinou":

A peça "BLITZ - O império que nunca dorme", que trata com
tom satírico da violência de Estado foi contemplada com o
ProAC (Programa de Ação Cultural) no edital de 2014. O
programa é do governo do estado [...]. A assinatura e
aprovação de projetos do Proac acontecem por órgãos
submetidos ao governo do Estado. A Polícia Militar é a força de
segurança que está submetida a esse mesmo governo."; e pelo
ator Caio Martinez Pacheco, algemado e detido depois da ação
policial que interrompeu a exibição da peça: "Essa dicotomia
entre o que o Estado permite e o que o Estado reprime é o que a
gente se deparou ontem, quando os policiais interromperam a
peça, baseado em uma prerrogativa bem subjetiva, de que eles
tinham se sentido aviltados com a nossa abordagem cômica e
estética com relação ao tema., 335

Apesar disso, não apenas o grupo foi coagido a interromper a exibição da peça naquele local, como cabe ressaltar que, mesmo após esse episódio, o grupo seguiu sendo perseguido por diferentes instâncias do poder público. Críticas vieram inclusive do próprio Governador do Estado à época, Geraldo Alckmin, que indiremente havia concedido ao grupo autorização e incentivos para exibirem sua arte. Houve também

\footnotetext{
335 CRUZ, Maria Tereza, "Grupo teatral vai ao Ministério Público questionar ação da PM em espetáculo", in: Carta Capital, 02 de novembro de 2016, Disponível em: $<$ https://www.cartacapital.com.br/politica/grupo-teatral-vai-ao-ministerio-publico-questionar-acao-dapm-em-espetaculo/> Acessado em 18 de agosto de 2019
} 
apresentações canceladas em Osasco onde, com a anuência do prefeito Celso Giglio, os vereadores desautorizaram a ação do seu secretário municipal de cultura Fernando Anitelli de trazer a peça à cidade, mostrando o conflito de interesses e o jogo de poder dentro de um mesmo governo, que acabam muitas vezes por desconsiderar o interesse público ao solapar assim a livre expressão democrática da arte.

Esse tipo de episódio deixa evidente a necessidade de que artistas e grupos que porventura estivessem iniciado acreditando vivermos em tempos mais afeitos à democracia parem de acreditar em suas próprias iniciativas isoladas como transformadoras solitárias da sociedade, além de mostrar os problemas de se dar cada vez mais poder à iniciativa estatal sobre o teatro, pois a máquina pública tanto pode dar o sustento de curto prazo pelo incentivo teatral como também pode aniquilar carreiras e reputações quando se pensa que isso lhes dará algum crédito com a opinião pública pesquisa de 2015 feita pela FECOMERCIO do Rio marca que 88,6\% dos brasileiros não vão ao teatro ${ }^{336}$, o que faz com que ataques como os desferidos pelos governos pareçam condizentes com o que a maioria pensa a respeito da atividade desses grupos.

Em um contexto onde os modelos associativos estão em franca crise, é de se perguntar se ainda há iniciativas que possam aglutinar artistas em uma luta coletiva. $\mathrm{O}$ Sindicato dos Artistas e Técnicos em Espetáculos e Diversões (SATED), órgão nacional de defesa da classe, tem uma inadimplência de quatorze mil associados em sua sucursal de São Paulo por contestações à gestão do órgão por Ligia de Paula desde sua saída em 2017, ao mesmo tempo em que trinta mil artistas estão registrados no estado ${ }^{337}$. Enquanto isso, a Cooperativa Paulista de Teatro tem quatro mil filiados e quatorze mil seguidores no Facebook, porém com interação e adesão mínima a suas chamadas virtuais, sendo acusada de angariar recursos para provimento de poucos beneficiados ${ }^{338}$, o que parece fantasioso pelo próprio número de beneficiados em editais públicos.

\footnotetext{
336 HERCULANO, Monica. "Hábitos culturais do brasileiro", in: Cultura e Mercado, Disponível em: <http://www.culturaemercado.com.br/site/mercado/habitos-culturais-brasileiro/> Acessado em 18 de agosto de 2019

${ }^{337}$ Segundo o último Congresso Estadual do SATED, agora dirigido por Dorberto Carvalho, alega-se que há apenas 500 sindicalizados adimplentes aptos a tomarem decisões em assembleias no sindicato. Lei de sindicatos, promulgada no Decreto-Lei n. 11.648, de 31 de março de 2008, em seu artigo IV prevê que para um sindicato ser reconhecido como interlocutor em assuntos da classe trabalhadora que busca representar, deve ter ao menos $7 \%$ de trabalhadores da área sindicalizados.

${ }^{338}$ Segundo Luis Carlos Moreira, do Engenho Teatral, a CPT arrecadaria 95\% de seu orçamento de quarenta milhões de reais com o poder público, para atender apenas $20 \%$ de seus associados. In DESGRANGES; LEPIQUE, 2012, p. 23
} 
Mesmo que o engajamento presencial pareça estar diminuindo, fazendo com que essas entidades reflitam uma tendência desmobilizante que parece atingir outras áreas, é notável que, em situações de ataque direto aos direitos conquistados, o meio teatral se coloca à disposição para o enfrentamento. Nos anos após o golpe parlamentar de 2016, houve tentativas de se colocar projetos de lei contra diversos modos de subsistência dos artistas, como propostas para se deixar de obrigar registro de ator/atriz e técnicos para quaisquer tipos de trabalho artístico ${ }^{339}$; mudanças na composição dos conselhos avaliadores e dos grupos que estariam habilitados a se inscrever no Fomento municipal; e o recrudescimento do controle censitório contra temas considerados delicados por grupos conservadores, como a transexualidade e a religião ${ }^{340}$.

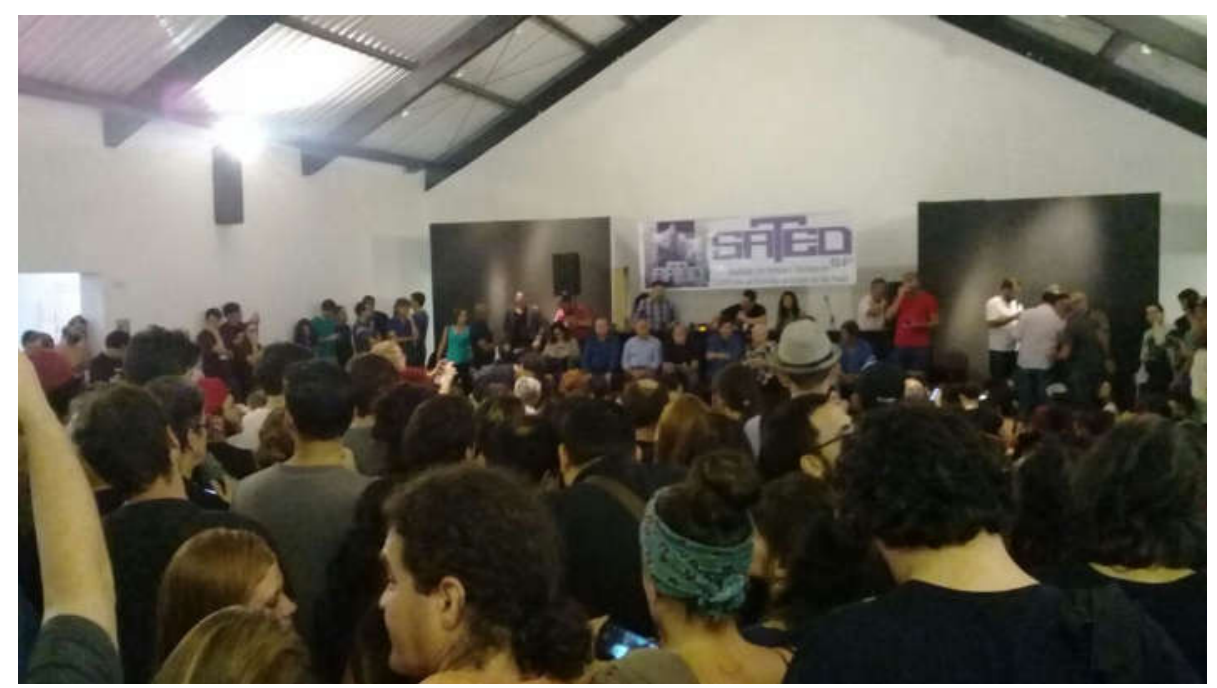

Imagem 31 - Mobilização do SATED na sede da FUNARTE em São Paulo em abril de 2018 contra proposta de lei que acabaria com a exigência de DRT para trabalhos artísticos.

Essa situação em que órgãos que deveriam representar coletivamente ao máximo de pessoas no meio teatral se vêem com problemas para angariar mobilização cotidiana para além de ações pontuais, dá espaço para grupos que arvoram representar grupos supostamente "excluídos" dessas discussões, na tentativa de ganhar espaço próprio.

\footnotetext{
${ }^{339}$ O registro é feito desde os anos 1940, e a lei que rege o sistema atual deste registro é a Lei de Regulamentação da Profissão Artística n. 6.533, de 1978. Cf em: SOUZA, Ludmila. "Fim da DRT do artista ameaça a economia criativa, diz MinC". In: Agência Brasil, 11 de abril de 2018. Disponível em: <http://www.tribunadonorte.com,br/noticia/fim-da-dRT-do-artista-ameaca-a-economia-criativa-dizminc/410012> Acessado em 20 de agosto de 2019

${ }^{440}$ Desde 2017, a peça "O Evangelho Segundo Jesus, Rainha do Céu", de Jo Clifford, interpretada por Renata Carvalho, sofre perseguições e censura em suas apresentações. Desde então, foram tantos os outros temas cuja abordagem foi atacada por grupos conservadores que isso motivou a criação pela Secretaria de Cultura Municipal do festival Verão Sem Censura, a ser realizado em janeiro de 2020.
} 
É o caso da chamada Rede de Teatros e Produtores Independentes, grupo que a partir da mobilização de seis teatros na cidade, como o Commune e o Viradalata, conseguiu barrar diversas edições do Fomento e também avançou sobre o ProAC progama de fomento estadual - a partir dessa alegação de exclusão contra a qual dizem lutar desde 2015. Ocorre que há sérios indícios de que o grupo se articulava desde seu início em órgãos governamentais que favoreceriam a aprovação de seus trabalhos ${ }^{339}$, em um claro sinal de promiscuidade pública para interesses privados, fazendo crescer a impressão de que estão se colocando apenas em prol de si próprios, sem ao menos se posicionarem publicamente em lutas coletivas por direitos de todo o meio teatral.

Afinal, é preciso ter em mente que a Lei de Fomento foi gerada num momento em que “(...) a correlação de forças sociais e políticas era favorável às lutas populares”,340, o que certamente não ocorre nos dias atuais, e que mesmo o Fomento não é uma lei de acesso universal. No ano passado, segundo levantamento da J.Leiva, $83 \%$ dos grupos que encenaram peças em São Paulo não se utilizaram de nenhum edital público, e dentre os que deles fizeram uso, o Fomento foi apenas o terceiro mais utilizado:

\begin{tabular}{|c|c|}
\hline ACESSO A EDITAIS E LEIS DE INCENTIVO - CIDADE DE SP - 2018 \\
\hline Editais & Leis de Incentivo \\
\hline $83 \%$ Sem apoio (17\% Apoio) & $86 \%$ Sem apoio (14\% Apoio) \\
\hline Editais utilizados: & Leis de incentivo utilizadas: \\
\hline$\bullet \quad$ Prêmio Zé Renato $-30 \%$ & $\bullet \quad$ Lei Rouanet $-64 \%$ \\
\hline$\bullet \quad$ ProAC $-25 \%$ & $\bullet \quad$ ProAC ICMS - $25 \%$ \\
\hline$\bullet \quad$ Fomento ao Teatro $-20 \%$ & $\bullet \quad$ Outros - $11 \%$ \\
\hline$\bullet \quad$ Outros $-25 \% *$ pulverizado entre mais de 10 tipos diferentes de edital \\
\hline
\end{tabular}
Fonte: LEIVA (2019)

Para falar da dificuldade que muitos dos grupos colocados entre os "tradicionais" dentre os que lutarem para que esta estrutura fosse construída, trato de dois exemplos colocados por grupos que existiam muito tempo antes do Fomento, e que seguem em atividade por vários meios, dentro das possibilidades de articulação própria e com os movimentos que permanecem ativos: são as companhias Cemitério dos Automóveis, liderada por Mário Bortolotto, e dos Satyros, de Ivam Cabral e Rodolfo García Vasquez.

\footnotetext{
339 BARSANELLI, Maria Luisa. "Ministério Público investiga suposto lobby na Lei de Fomento ao Teatro", in: Folha de S. Paulo, 18 de setembro de 2018. Disponível em:<http://www1.folha.uol.com.br/ilustrada/ 2018/09/ministério-publico-investiga-suposto-lobby-na-lei-de-fomento-ao-teatro.shtml> Acessado em 22 de agosto de 2019

${ }^{340}$ Entrevista de Dulce Muniz, in: BETTI, Op. Cit., in: DESGRANGES; LEPIQUE, 2012, p. 121
} 
O Cemitério dos Automóveis, durante seus mais de trinta anos de atuação na cena teatral, orbitou sempre em torno das ideias e projetos de seu mentor Bortolotto, que também buscava praticamente sozinho os meios para prover a concretização deles. Sobre sua relação com o Fomento, ele cita em entrevista com Sebastião Milaré ${ }^{341}$ ter recebido recursos para as montagens de "A frente fria que a chuva traz" (2003), "Homens Santos e Desertores" (2004) e "Chapa Quente" (2006), porém chega a lamentar pela falta de continuidade dos projetos, por não ter sido contemplado para o ano de 2005.

Bortolotto chega a colocar que foi essa falta de continuidade que fez com que tivessem que deixar naquele ano espaço próprio da companhia na Bela Vista, alugado com recursos do Fomento, por não ter como manter o teatro apenas com renda da bilheteria e não ter outras fontes de recurso para manutenção do local. Ele dizia que:

"[...] a gente não tinha como sustentar, com nosso ingresso de cinco a dez reais [...] para que a rapaziada vá mesmo (ao teatro). Eles iam ver todas as peças, mas eram sessenta lugares. Você vai dividir a bilheteria com a rapaziada, não dá nada; não dá pra pagar nem a luz de dois dias do teatro. Então, dependia muito do fomento [...] acontece isso, de você estar fazendo um trabalho que, depois, tem que interromper. E aí, espera de novo para entrar no programa e passa um ano até conseguir o fomento de novo, mas aquele trabalho que você estava fazendo já foi interrompido. "342

É como se o subsídio garantisse a Bortolotto e sua companhia momentos fugazes de subsistência, mas sem aparentemente haver planejamento a longo prazo. Hoje, a companhia tem espaço na Rua Augusta, e busca continur ativa a partir do engajamento de seu público fiel e flutuante, a partir do chamariz do bar em seu espaço e da campanha de crowdfunding permanente que empreende pela sua manutenção. Nestes tempos em que essas campanhas se mostram uma grande tendência para chamar atenção à continuidade de projetos especiais, vale lembrar que mesmo o Oficina tem campanha semelhante após perder os patrocínios de companhias estatais como a Petrobrás, que por muito tempo garantiram sua excelência cênica e de produção, além de suas turnês.

\footnotetext{
${ }^{341}$ ÁGORA TEATRO, 2006, p. 80

${ }^{342}$ Ibid., p. 80-1
} 
O Satyros também chegou a fazer um crowdfunding, mas para um projeto especial que ainda busca implementar: a reabertura do Cine Bijou, na mesma região da Praça Roosevelt onde se instalou desde 2000, trazendo toda uma redifinição para a geografia social do lugar, considerado abandonado até sua chegada. Para manutenção de seus dois espaços próprios na praça, café e outras atividades como a organização anual do festival Satyrianas, eles entram em duas frentes institucionais que se encontram com o poder público em diferentes instâncias.

Primeiro, com o poder municipal, há parcerias pontuais para eventos, além de participarem normalmente de seus editais - sobre o Fomento, García Vasquez comenta que “(...) passa seis meses ensaiando diariamente, cinco horas por dia, uma peça com vinte e um atores (sem) nem pensarmos se ia ter fomento, se não ia, (...) se achava que precisava montar esse espetáculo, vai lá e monta" ${ }^{343}$. E assim o grupo ganha ou perde concorrência pública normalmente. E com o Governo do Estado, o grupo abriu uma parceria mais longeva e ousada, através de uma OS que ajuda a administrar um importante equipamento de formação teatral - a SP Escola de Teatro - desde 2010 na mesma praça onde está a sede do grupo e com uma segunda unidade no Brás.

Outra ressignificação de local degradado, que ainda está em curso devido à sua complexidade, é a empreendida pelas companhias Mungunzá e Pessoal do Faroeste, na região da Luz - que já foi a Boca do Lixo do cinema dos anos 1970 e onde hoje há uma ilha de alta cultura e institucionalidade, na sede da Secretaria de Estado da Cultura e da Orquestra Sinfônica do Estado de São Paulo, que parece não chegar ao seu entorno. De modo completamente diferente, essas companhias teatrais aliam uma ação direta para com as populações carentes e vulneráveis da região com uma chamada à presença em seus espaços não apenas do público de suas peças, mas de outras companhias para ocuparem estes espaços para apresentações e mesmo eventos e cursos de curta duração.

Essa articulação e troca de experiências faz com que a ocupação do local se torne quase permanente, gerando movimento para a região. Outro modo de trabalhar com o teatro na cidade de forma a engajar público e artistas em um pensamento comunitário são as casas que se colocam como centros culturais. Sendo o meio mais propício para fomentar atividades em lugares periféricos, pela total falta de infraestrutura de prédios

${ }^{343}$ ÁGORA TEATRO, 2006, p. 81 
próprios para a prática teatral nesses locais - salvo os teatros da unidades do Centro Educacional Unificado (CEU) -, esse meio de congregar ação cultural e praticidade também está bastante presente em zonas mais centrais. Um bom exemplo desse modo de organização é a Associação Zona Franca, sediada na Bela Vista, e que tem articulação com dezenas de equipamentos das mais variadas funções na região para alimentar o sentimento de pertencimeto à comunidade onde está inserido - até construtoras que operam na região, como a TONE, ajudaram na reforma do espaço. Enquanto pedem contribuições e doações voluntárias, administram o local de forma a prover atividades às companhias que alugam o espaço, como a Velha Companhia, que a utiliza para ensaios, oficinas e apresentações.

Essas lutas, diferente das ações do Arte Contra a Barbárie que se centravam em discutir políticas para grupos teatrais autônomos para provimento de suas necessidades, centram-se agora em defesa dos espaços de encenação e do patrimônio teatral a ser paulatinamenteabandonado por entidades públicas e privadas apesar do potencial aumento de demanda de um público que busca frequentar mais o teatro - a mesma pesquisa nacional da FECOMERCIO do Rio apontava em 2017, dois anos após a pesquisa anterior, aumento de $11 \%$ no interesse do público pelo teatro, fazendo a porcentagem dos que efetivamente haviam assistido a uma peça ir de $11 \%$ para $16 \%{ }^{344}$.

A partir de muitos dos que se levantaram no movimento Arte Contra a Barbárie, estabeleceu-se em 2015 o Movimento dos Teatros Independentes de São Paulo (MOTIN), associação que busca junto ao MTG (Movimento Teatro de Grupo) valorizar os espaços conquistados pelos grupos após o primeiro movimento e que estariam sendo desmantelados pela descontinuidade de políticas de apoio, ou por incertezas cotidianas daqueles que não as recebem sempre ou ficam completamente sem esses recursos até novo chamamento. Quando do anúncio do movimento em 2015, foi lançada uma Cartografia dos Teatros de São Paulo ${ }^{345}$, com uma classificação das salas de espetáculo separando os estabelecimentos teatrais em Independentes (quarenta e três espaços), Públicos (dezoito espaços) e Patrocinados (oito espaços).

\footnotetext{
${ }^{344}$ GANDRA, Alana, "Brasileiros frequentam mais teatros e cinema, diz pesquisa”, in: Agência Brasil, Disponível em: <http://agenciabrasil.ebc.com.br/cultura/noticia/2017-04/brasileiros-frequentam-maisteatros-e-cinemas-diz-pesquisa> Acessado em 18 de agosto de 2019

${ }^{345}$ MOTIN/PROVOKERS, Cartografia dos Teatros de São Paulo: Estudo Quantitativo, São Paulo, Governo do Estado, 2015, Disponível em: <http://motin.org.br/Files/cartografia.pdf> Acessado em 18 de agosto de 2019
} 
O movimento também criou subitems onde coloca de modo mais claro uma separação entre estabelecimentos sem fins lucrativos (registrados como ONGs ou OSCIPs) e aquelas com fins lucrativos, registradas como empresas ou sociedades limitadas, com uma proporção equivalente entre si dentro do âmbito dos teatros classificados nesse levantamento como independentes. Ainda que todos estes façam contratações como Pessoa Jurídica (PJ) ou Microempreendedor Individual (MEI) desde o início dos anos 1990, OSCIPs teoricamente estariam sob a mesma jurisdição que as OS, mas acabam sendo favorecidas indiretamente por terem menores restrições quanto à transferência de recursos do município para suas ações (BETTI, in: DESGRANGES; LEPIQUE, 2012, p. 123). Além disso, seu modo de atuação se espalha por muitos equipamentos teatrais da cidade, pelo fato do questionamento à organização de uma OS ser maior, tanto por parte da sociedade como dos órgãos de controle governamental. $\mathrm{O}$ exemplo recente mais notório disso é a contenda pelo controle do Teatro Municipal.

Primeiro, com as acusações contra entidade dirigida por John Neschling - exmaestro da Orquestra Sinfônica do Estado de São Paulo - que acabou perdendo contrato com o teatro após ter consumido apenas em 2015 quase cem milhões de reais do orçamento municipal ( $20 \%$ de toda a arrecadação da Secretaria naquele ano), e posteriormente com as mudanças constantes de direção e linhas artísticas privilegiadas pela organização que tomou seu lugar. Quanto ao uso desse financiamento por parte de teatros independentes, o levantamento do MOTIN acaba por desmistificar o argumento que coloca artistas como puros "mamadores de recursos públicos", ao apontar que:

Os independentes tem fontes de recursos muito diversas $e$ nenhuma muito representativa, (ou seja, com nenhuma fonte classificada predominando sobre a outra, dentre bilheteria, recursos dos sócios, locação de salas para os que tem espaço próprio, e eventuais patrocinadores), enquanto os Públicos dependem de suas entidades mantenedoras (prefeitura ou estado). Os Teatros Patrocinados (com nomes de empresas, marcas, bancos ou entidades patronais) dividem seus recursos entre empresas e bilheteria. ${ }^{346}$

Outro importante dado do documento, que ajudou a criar uma política pública específica para tais espaços, foi o de que os Independentes pagavam uma quantia total de quase doze mil reais em IPTU. Essa obrigação acabou por ser revogada através da 
Lei Municipal N. 16.173, de abril de 2015, que colocou critérios de isenção para teatros e centros culturais com até quatrocentos lugares, e que tenham acesso direto por ruas ou galerias. No caso dessa lei, o MOTIN teve suporte direto da CPT na sua reivindicação e interlocução com o poder público. Esta resolução também abriu espaço e deu impulso para novas parcerias privadas, como a do Teatro Novo, reformado em uma galeria na Vila Mariana e alugado para apresentações diversas desde então.

Em relação aos teatros comerciasi, importante movimento também está sendo articulado em nível municipal. Este movimetno se reúne desde o final de 2018 capitaneado por André Acioli, produtor responsável pela programação de grandes teatros da capital, como o Vivo, Porto Seguro e o Eva Herz (dentro do Conjunto Nacional, na Avenida Paulista) - todos teatros patrocinados por empresas e com programação rotativa, pois não há teatros desse tipo com companhia fixa em São Paulo.

Nesse sentido, é de se pensar que companhias privadas cada vez mais investem em teatros onde possam ostentar suas próprias marcas como chamariz e para agregarem valor às mesmas. Um exemplo cabal desse tipo de relação entre patrocinadores e espaços teatrais se dá com o Teatro Renault, na avenida Brigadeiro Luiz Antônio, na região da Bela Vista. Ele foi construído em 1929 como um cinema sob patrocínio dos estúdios Paramount, dos Estados Unidos, tendo sido o primeiro cinema sonoro na América Latina. Nos anos 1960, ficou famoso por também receber festivais de música popular, principalmente os concursos transmitidos pela televisão.

Após ter sido destruído por um incêndio em 1969, voltou à atividade pouco tempo depois, mas não suportou sua própria decadência e fechou em 1996. Em 2001, o Grupo Abril, então dono de um império de comunicação, firmou parceira junto com a representação brasileira da mexicana Corporación Interamericana de Entretenimento, uma firma de franquias de teatro e música com contatos com os espetáculos da Broadway de New York e do West End de Londres, que trazia para o México e eventualmente a outros países da América Latina, como a Argentina.

Com isso, seu enorme espaço que comporta dois mil espectadores traz espetáculos desses locais, quase sempre em produções brasileiras encomendadas especialmente para o espaço. Em 2012, com o Grupo Abril demonstrando certa debilidade institucional, o 
teatro foi vendido à multinacional Time for Fun, que repassou os direitos do nome do local para a francesa Renault, que nomeia o teatro até hoje ajudando a fomentar a febre dos musicais no país, com as mais caras produções no país hoje financiadas em grande parte por renúncia fiscal e com lucros exorbitantes às empresas pelo preço cobrado pelos ingressos.

Esta introdução do gênero musical no país de modo contínuo e centralizado em locais específicos se tornou um investimento de grande retorno para as empreaas que nela colocaram seu dinheiro, seja por investimento direto ou renúncia fiscal. Isso acabou por ser um fomentador de uma mudança de mercado, em que produções locais baseadas em conteúdo brasileiro foram montadas com oriundos de escolas especializadas no próprio gênero musical, além de aproveitar também atores do gênero dramático. Tais ações reforçam a ideia que essas empresas tinham sobre marketing cultural e economia criativa, gerando um movimento que tende a apenas crescer concentrando renda.

Levantamento feito em 2002 junto a mais de sessenta empresas que investem de forma rotineira em atividades culturais mostrou dados interessantes dos padrões de empresas patrocinadoras. Em primeiro lugar, elas investem majoritariamente também em ações sociais, relacionando esta atividade à cultura mais do que a educação, por exemplo. Além disso, o patrocínio direto das empresas junto ao chamado apoio institucional ainda seriam os mais utilizados meios de inserção das empresas em ações culturais para promoção de suas marcas - $65 \%$ das empresas patrocinadoras também dão apoio a outras manifestações culturais ${ }^{347}$.

Pensando no modelo de financiamento das companhias menores fora do big business, mais pulverizado e democrático em sua expressão, a partir do que foi estruturado pelo movimento Arte Contra a Barbárie, foram feitos estudos de políticas públicas que mapearam possibilidades de subvenção para grupos da cidade - para além das emendas parlamentares, que seguem sendo uma fonte de subsídios bastante utilizada em urgências e momentos excepcionais, como quando editais como o Fomento são suspensos. O resultado desse estudo de possibilidades para financiamento aos grupos da cidade de São Paulo através de editais e prêmios pode ser visto na tabela a seguir:

${ }^{347}$ INSTITUTO CULTURAL CIDADE VIVA, 2003, p. 50-1 


\begin{tabular}{|c|c|c|}
\hline \multicolumn{3}{|c|}{ PRÊMIOS E EDITAIS PÚBLICOS PARA ARTES CÊNICAS EM SÃO PAULO -2019 } \\
\hline Órgão competente & Prêmio/Edital & Objetivo \\
\hline \multirow[t]{10}{*}{$\begin{array}{l}\text { FUNARTE } \\
\text { (Governo Federal) }\end{array}$} & $\begin{array}{l}\text { Prêmio Myriam Muniz } \\
\text { (última edição: 2011) }\end{array}$ & $\begin{array}{l}\text { Desenvolvimento de espetáculos e ajuda } \\
\text { na montagem e circulação }\end{array}$ \\
\hline & Prêmio de Dramaturgia & $\begin{array}{l}\text { Incentivo à publicação de obras inéditas de } \\
\text { teatro adulto e infantil }\end{array}$ \\
\hline & $\begin{array}{l}\text { Circulação de Espetáculos } \\
\text { Circenses }\end{array}$ & $\begin{array}{l}\text { Apoio para circulação de espetáculos de } \\
\text { rua em todo o país }\end{array}$ \\
\hline & Arte e Educação & $\begin{array}{l}\text { Projetos e propostas para integração de } \\
\text { artes com iniciativas educacionais }\end{array}$ \\
\hline & Laboratório da Cena & $\begin{array}{l}\text { Propostas de pesquisa, ensaio, criação e } \\
\text { formação de peças em salas da fundação }\end{array}$ \\
\hline & $\begin{array}{l}\text { Espetáculos de Artes } \\
\text { Cênicas e Música } \\
348\end{array}$ & \multirow{2}{*}{$\begin{array}{l}\text { Propostas de ocupação artística de } \\
\text { espetáculos prontos em espaços da } \\
\text { entidade (em SP, Teatro de Arena e salas } \\
\text { da FUNARTE) }\end{array}$} \\
\hline & $\begin{array}{l}\text { Cena Aberta } \\
\text { (última edição: 2016) }\end{array}$ & \\
\hline & $\begin{array}{l}\text { Doação de Equipamentos de } \\
\text { Iluminação Cênica }\end{array}$ & $\begin{array}{l}\text { Busca de melhoria de infraestrutura } \\
\text { técnica em espaços estabelecidos há pelo } \\
\text { menos três anos da inscrição }\end{array}$ \\
\hline & Iberescena & $\begin{array}{l}\text { Apoio a coproduções, festivais e processos } \\
\text { de criação entre artistas locais e outros da } \\
\text { América e Europa (Espanha) }\end{array}$ \\
\hline & $\begin{array}{l}\text { Bolsa para Formação e } \\
\text { Residência } \\
\text { (última edição: 2016) }\end{array}$ & $\begin{array}{l}\text { Apoio com bolsa anual a projetos de } \\
\text { residência e aperfeiçoamento } \\
\text { profissionais no Brasil ou exterior }\end{array}$ \\
\hline \multirow[t]{4}{*}{$\begin{array}{lll}\text { Secretaria de } & \text { Cultura } \\
\text { Estado SP } & & \end{array}$} & $\begin{array}{l}\text { Prêmio Governador do } \\
\text { Estado }\end{array}$ & Prêmio a destaques em áreas artísticas \\
\hline & $\begin{array}{l}\text { Pontos de Cultura } \\
\text { (ligado ao Cultura Viva - } \\
\text { federal e municipal) }\end{array}$ & $\begin{array}{l}\text { Programa de incentivo e reconhecimento a } \\
\text { entidades e coletivos para manutenção e } \\
\text { permanência em seus locais de atuação }\end{array}$ \\
\hline & $\begin{array}{l}\text { ProAC } \\
\text { (Programa de Ação Cultural) }\end{array}$ & \multirow{2}{*}{$\begin{array}{l}\text { Editais das mais diversas áreas - criação e } \\
\text { publicação dramatúrgica, de integração de } \\
\text { artes, e produção e circulação de dança, } \\
\text { circo, teatro (adulto, infantil e de rua), } \\
\text { tanto prontos como em formação }\end{array}$} \\
\hline & $\begin{array}{l}\text { ProAC ICMS } \\
\text { (Incentivos Fiscais) }\end{array}$ & \\
\hline \multirow{10}{*}{$\begin{array}{l}\text { Secretaria de Cultura } \\
\text { Município SP }\end{array}$} & Prêmio Zé Renato & \multirow{2}{*}{$\begin{array}{l}\text { Produção de obras inéditas de grupos } \\
\text { locais e circulação de espetáculos prontos } \\
\text { em teatros da cidade }\end{array}$} \\
\hline & Prêmio Cleyde Yáconis & \\
\hline & Fomento ao Teatro & \multirow{2}{*}{$\begin{array}{l}\text { Apoio à pesquisa, criação, produção, } \\
\text { manutenção e acesso a obras artísticas de } \\
\text { grupos da cidade de forma continuada }\end{array}$} \\
\hline & Fomento à Dança & \\
\hline & $\begin{array}{l}\text { VAI } \\
\text { (Valorização de Iniciativas } \\
\text { Culturais) }\end{array}$ & \multirow{2}{*}{$\begin{array}{l}\text { Estímulo à criação e difusão de iniciativas } \\
\text { produzidas por grupos e coletivos nas } \\
\text { regiões limítrofes da cidade, recém } \\
\text { estabelecidos ou com ao menos dois anos } \\
\text { de atuação na região }\end{array}$} \\
\hline & Fomento à Periferia & \\
\hline & $\begin{array}{l}\text { PIÁ (Programa de Iniciação } \\
\text { Artística) }\end{array}$ & \multirow{2}{*}{$\begin{array}{l}\text { Estímulo a educadores do teatro para } \\
\text { integração de artes com iniciativas } \\
\text { educacionais para crianças e jovens }\end{array}$} \\
\hline & Vocacional & \\
\hline & $\begin{array}{l}\text { Apoio aos Espaços } \\
\text { Independentes }\end{array}$ & $\begin{array}{l}\text { Fomento, difusão e manutenção de espaços } \\
\text { indenpendentes na cidade }\end{array}$ \\
\hline & $\begin{array}{l}\text { PROMAC (Programa } \\
\text { Municipal de Ação Cultural) }\end{array}$ & $\begin{array}{l}\text { Edital de perfil semelhante ao ProAC } \\
\text { estadual }\end{array}$ \\
\hline
\end{tabular}

Fonte: sites da FUNARTE, Sec. Estado da Cultura, Prefeitura de SP e Sec. Cultura SP

${ }^{348}$ Até 2017, a FUNARTE abria editais exclusivos para projetos de artes cênicas. Desde 2018, os editais para tal fim foram chamados em conjunto com os de projetos musicais. 
Os prêmios e editais apresentados seguem linhas gerais conincidentes em relação à sua atuação, e muitos acabam tendo atribuições semelhantes, com pequenas mudanças de foco entre si. Entre os programas com maior foco educacional, por exemplo, a diferença está no alcance principal em crianças (PIÁ) ou adolescentes (Vocacional), ou para públicos livres (Arte e Educação). Entre o VAI e o Fomento à Periferia, a diferença maior é que o VAI comtempla ações tanto de coletivos jovens que começam a se inserir na produção cultural, como projetos de grupos mais consolidados, também alvo do Fomento à Periferia. Outros programas como o Laboratório em Cena (FUNARTE) e o Apoio a Espaços Independentes (Prefeitura), no entanto, têm lógicas parecidas.

Dessa forma, para além disso deve-se considerar tanto a busca de recursos através da dotação regular das secretarias, que teoricamente iriam para provimento dos diferentes atores culturais para atendimento de diferentes necessidades, como também por editais específicos de entes culturais públicos ou privados. É o caso da Mostra de Dramaturgia do Centro Cultural São Paulo (equipamento da Prefeitura), que promove a criação de textos inéditos a serem encenados em um ciclo de peças no próprio local que é replicado em iniciativas semelhantes, com outros métodos de seleção, na FUNARTE e SESC - e dos editais de instituições ligadas a bancos públicos (Centro Cultural Banco do Brasil, Caixa Cultural) e privados (Itaú Cultural) que promovem de forma contínua a encenação de obras cênicas de diferentes matizes, ainda que não estejam diretamente envolvidas em suas produções.

Sendo assim, os prêmios e editais tratam de recursos providos através de dotações que se encontram dentro do orçamento tanto dos referidos órgãos públicos que os promovem como também do MinC, apesar desse trabalho considerar a estrutura do órgão anterior à sua atual configuração, completamente mudada em relação a como ele foi construído originalmente ${ }^{349}$. Por tais recursos estarem desvinculados de outros apoios dados isoladamente por departamentos vários dentro do organograma fixo desses entes, seu uso é de certa forma considerado mais abrangente pelo próprio meio teatral. Assim, estes parecem preferir a inserção nessa lógica de editais públicos do que ir atrás de apoios excepcionais que demandariam negociações e costuras políticas muito mais

\footnotetext{
${ }^{349} \mathrm{O}$ MinC, fundado como ministério independente após a redemocratização do país em 1985 com o desmembramento do MEC (Minstério da Educação e Cultura), foi rebaixado ao status de Secretaria subordinada ao novo Minstério da Cidadania a partir do governo que tomou posse em 2019, após já ter passado pelo mesmo processo de "rebaixamento" entre 1990 a 1992 e em 2016.
} 
complexas e incertas, como dotações advindas de emendas parlamentares que realocam recursos não usados por outras áreas para atender a certas demandas.

Nesse caso, uma questão a se pensar quando se trata dos recursos dos prêmios e editais é o quanto a dotação aos contemplados pode ser pequena em relação ao montante total utilizado pelos mesmos. No ProAC (do governo estadual), que seria o mais abrangente por não estabelecer um valor pré-determinado de recursos a serem recebidos pelos "habilitados", quatrocentos e quatorze projetos das mais diversas áreas receberam em 2017 uma média de pouco mais de sessenta e cinco mil reais cada.

A média é semelhante, por exemplo, ao recebido por projeto no VAI, mas é muito menos que outros prêmios que acabam contemplando muito menos projetos: o Fomento à Periferia atendeu em 2018 vinte e seis coletivos de maior abrangência com valores que vão de cento e vinte e cinco mil a trezentos e quinze mil reais anuais. E mesmo estes tem problemas sérios em sua liberação, que forçaram o último Secretário de cultura da cidade, Alê Youssef, a se reunir em audiência pública com mais de trezentas pessoas de coletivos ligados ao Movimento Cultural das Periferias em 12 de março de 2019, no Teatro do Pessoal do Faroeste.

Porém, além de pensar no desafio e possível alcance dos projetos (mais recursos pode configurar maior complexidade de produção e potencial de público), também é fato que os prêmios acabam alinhavando uma grande porcentagem dos recursos ordinários em alguns órgãos que parecem tomá-los como sua política principal para as artes. No caso do Estado de São Paulo, por exemplo, no ano de maior dotação para os editais ProAC e ProAC ICMS - 2014 -, o montante distribuído por eles (que chegou a cento e setenta e oito milhões de reais) correspondeu a $19,1 \%$ de todo o orçamento anual da Secretaria de Cultura (novecentos e vinte e nove milhões), fazendo com que muitos vejam editais como a principal, senão única, política pública voltada aos artistas do teatro. Mesmo muitos dos contemplados insistem que, para além do reconhecimento de um projeto nos editais, seja trabalhada uma forma de se libertarem dessa “dependência" com uma sustentabilidade própria ${ }^{350}$.

\footnotetext{
350 SOUZA, Mateus de, "Artistas da periferia querem ir além da lei de fomento", 20 de julho de 2018, atualizado em 04 de novembro de 2018, in: Agência Mural, Disponível em: <https://www.agenciamural.org.br/artistas-da-periferia-querem-ir-alem-da-lei-de-fomento/> Acessado em 18 de agosto de 2019
} 


\subsection{Políticas Públicas Nacionais e sua Influência nos Modos de Produção}

As políticas nacionais que se voltavam a ajudar o teatro sempre pareceram condicionais e reguladas ao extremo, apesar para que exceções às suas regras pudessem

ser legitimadas. É como se uma luta estivesse sendo travada entre os artistas, que lutam por reconhecimento e para manter sua pequena "indústria cultural" funcionando a contento, enquanto do outro lado o cabo de guerra pende na maior parte das vezes com mais força, puxando para baixo a vontade de se resolver tais questões. Nada parece pensado e feito para durar muito tempo.

Isso aconteceu mesmo ao SNT, tendo passado por vários governos de diferentes matizes, inclusive pela ditadura civil-militar de 1964 a 1985, e que adquiriu um destaque importante na tentativa de busca por um padrão no modo de se gerenciar o teatro no Brasil pela forma como seu trabalho passou a servir como parâmetro para as companhias do país. Antes do seu fim, o SNT ainda buscava retomar protagonismo se reorganizando com a chegada do empresário Orlando Miranda à sua presidência em 1974, após pressão de entidades do Rio de Janeiro.

Ele seguiu ativo de forma a se considerar que tenha cumprido grande parte do seu papel de subvenção às artes cênicas no país mesmo após novas mudanças de nomenclatura - para Instituto Nacional de Artes Cênicas (INACEN) em 1981, e Fundação Nacional de Artes Cênicas (FUNDACEN) em 1987 - até sua extinção definitiva em 1990, com toda informação acerca do funcionamento das companhias teatrais brasileiras, essencial para se ter um planejamento mais organizado da atividade teatral no país, arquivado posteriormente na FUNARTE, outro órgão federal criado para a subvenção de todas as artes em 1975.

Essa documentação sobre as companhias de teatro brasileiras, guardada hoje dentro do Arquivo Institucional da FUNARTE, era muito usada pelas próprias companhias e artistas no período de funcionamento da SNT para se obterem parâmetros de mercado e informações que seriam consideradas mais sensáiveis e reservadas sobre o cotidiano de companhias que se extinguiram, sendo importante porque também, para a pesquisadora Tânia Brandão (apud CAMARGO, 2017): 
(Era preciso) evidenciar as tensões que cercaram o advento do teatro moderno no Brasil ao se questionar (a razão das) modificações do setor teatral não se realizarem continuamente e "em progresso" como muitas vezes fora retratado (em público). ${ }^{351}$

Assim o arquivo guardado na FUNARTE, e lá reunido desde seu fechamento, tambem guardaria:

\begin{abstract}
Processos (com uma) variada gama de informações, enumerando dados como elenco, repertório, gastos com a produção de espetáculos, salários de artistas e técnicos, valores de aluguel dos edifícios teatrais, número de representações, excursões, atividades realizadas, preços de ingressos, esboços de práticas de formação de público, entre outros dificilmente encontrados em colunas teatrais, programas ou arquivos privados. ${ }^{352}$
\end{abstract}

Não que não tivessem havido ações do MEC voltadas para a culturadurante o regime civil-militar: houve importantesresoluções, com a sistematização de um primeiro projeto de Política Nacional de Cultura implantado em 1975, que obrigava o Estado a respeitar a liberdade de criação ${ }^{353}$ e a fundação Pró-Memória que revitalizava o trabalho do IPHAN dentro da estrutura do Departamento de Assuntos Culturais - seção do MEC alinhada às pautas culturais. Mas nada de específico para as necessidades de reorganização do meio teatral - por essa ausência do Estado naquele momento, entendia-se a emergência maior das associações de classe, seja por parte dos produtores ou dos grupos.

Hoje em dia, um órgão centralizador para as atividades cênicas com tamanho poder e controle sobre as atividades dos artistas poderia ser considerado tanto como salvação por uns ou como um disparate por outros, pois ainda que a existência dos Ministérios e Secretarias de Cultura se mostre vital para a continuidade da atividade teatral no país hoje, tais órgãos governamentais teoricamente não ditam um padrão para a prática teatral, que deve mesmo ser projeção da livre expressão do artista sem maiores interferências externa, seja do produtor-mecenas ou do órgão estatal ${ }^{354}$.

${ }^{351}$ CAMARGO, 2017, p. 173

352 Idem Ibidem

353 PARREIRA, Roberto. “Estado e cultura: Fomento vs. Paternalismo”, in: MICELI, 1984, p. 235

${ }^{354}$ Arnold Hauser em "História Social da Arte e da Literatura" (1951), fala que a relação dos artistas com seus produtores e mecenas, quer seja a Igreja, o príncipe, o empresário, ou o Estado, sempre seria conflituosa, pois “(...) há artistas que só se sentem seguros quando estão livres, mas há os que só 
Apesar disso, esses órgãos parecem hoje não se atentar com o devido cuidado a muitas daquelas que também seriam suas atribuições no sentido de dar um norteamento mais claro nos parâmetros organizacionais que novos e velhos artistas, e suas companhias, deveriam seguir para alcançar determinados objetivos técnicos de qualidade e de alcance na sociedade, deixando de lado possibilidades de sistematização e continuidade de políticas públicas sólidas.

No Brasil, uma política que trouxe um primeiro viés para essa problematização da influência pública sobre a arte fazendo com que setores privados avançassem sobre o orçamento e as definições de políticas públicas, com anuência do poder Executivo federal, foi a Lei Sarney, promulgada pelo então presidente da República em 1986 celebrando a então recente criação do Ministério da Cultura (MinC), cuja separação do Ministério da Educação se deu no ano anterior sob a direção de Celso Furtado. Com essa primeira lei, permitiu-se tomar renúncia fiscal a partir de projetos apresentados ao MinC com resultados a serem entregues tanto ao Ministério como à Receita Federal, então administradora única dessas operações.

Um problema dessa lei, além de tirar autonomia de definição de políticas de um órgão recém-criado como o MinC, deixando que o "mercado" - então dominado pelo pensamento neoliberal de sociedade - pela primeira vez definisse qual direcionamento dar para os investimentos (ou no caso, renúncias fiscais) públicos, é que a lei permitiu distorções como a não obrigatoriedade de uma contrapartida pública para o produto $\operatorname{artístico~}^{355}$. Isso fazia com que muitos resultados desses financiamentos não viessem a ser exibidos de modo amplo para o público geral, graças à falta de controle externo à máquina pública a respeito desses trabalhos. Apesar de a lei ter sido revogada em 1990, logo substituída pela Lei Rouanet, essa pressão política sobre as iniciativas de fomento ao teatro não pode ser considerada uma possível interrupção no fator de influência dos governos sob a produção teatral. A partir daí, políticas onde artistas se colocavam em posição de aderir ou se opor a essas práticas se intensificaram.

respiram livremente quando estão seguros”, fazendo a existência do artista estar sempre a perigo, “(...) quer em uma ordem social autoritária, quer em uma liberal, pois nenhuma delas é isenta de risco: uma dá-Ihe menos liberdade; outra, menos segurança.", in: MICELI, 1984, p. 225-7

355 HERCULANO, Monica, "Lei Sarney, Lei Rouanet, Procultura: história, avanços e polêmicas", in: Cultura e Mercado, 2012, Disponível em: <http://www.culturaemercado.com.br/site/leirouanet/lei-sarney-leirouanet-procultura-historia-avancos-e-polemicas/> Acessado em 18 de agosto de 2019 
Existem muitas diferentes maneiras de produzir um espetáculo teatral, e há um esforço por parte dos órgãos patrocinadores públicos ou privados e dos grupos teatrais em conciliar as possibilidades oferecidas para a execução e manutenção do fazer teatral e as demandas artísticas dos fazedores e espectadores teatrais dentro dos seus diferentes modos de produção. Da parte do espectador, as exigências e expectativas com o que é visto no palco ou em espaços não convencionais podem variar conforme as propostas de cada grupo, porém “(...) não importa que haja uma mudança radical no lugar físico do espectador, seu lugar subjetivo permanece inalterado (pois ele) continua a vir de fora do teatro, e para fora do teatro retorna após o espetáculo" (CARNEIRO, 2017, p. 42).

Se uma encenação busca uma representação mais naturalista ou um espectador envolvido emocionalmente, é bastante possível que cada proposta encontre seu próprio público dentro da cena contemporânea. Para acomodar essas diferentes demandas e ideias artísticas, pensa-se em grupos e espaços históricos e icônicos, como o Teatro Oficina e o Teatro de Arena - hoje administrado pela FUNARTE rendendo homenagem a Eugênio Kusnet -, que por vezes se abrem a propostas de outros grupos que aproveitam suas estruturas, onde espectadores são parte integrante da montagem. É pensando não em discriminar, mas em abarcar todas as manifestações da expressão teatral em sua diversidade que o poder público, principalmente através dos prêmios e editais que institui, toma para si a tarefa de administrar espaços teatrais.

Sendo assim, ainda que haja maneiras para seguir subsistindo com um subsídio próprio de maior risco para manutenção de um projeto de trabalho artístico, como associar-se em cooperativas e sindicatos para que junto a outros artistas haja ajuda para subvencionar um lugar próprio ou compartilhado. Quer ele seja pensado para durar por algum tempo ou utilizado propositalmente como uma sede não permanente, esse tipo de pensamento acaba por minar muito de um possível planejamento para alçar voos maiores, visto que aumenta o número de montagens que se tornam itinerantes dentro da própria cidade de São Paulo, não fazendo temporadas fixas de mais de um mês. Além do mais, essa adesão a modelos associativos parece não se dar hoje como foi em outros tempos, pois o apoio hoje é muito mais circunstancial e pouco propenso a uma maior fidelidade a causas coletivas, com cada grupo cuidando de sua própria organização interna pelo fato de sua manutenção se tornar uma empreitada cada vez mais complexa. 
A impressão é que, usando um exemplo hipotético de uma determinada companhia - ou coletivo, pensando na nomenclatura contemporânea similar -, o projeto precisaria, para ser concretizado, um produtor e também um captador de recursos, com boa lista de contatos, e um diretor de marketing que banque o seu projeto. Tudo isso, se possível, na mesma pessoa. Isso é sentido pelo Oficina, onde um captador de recursos seria a única coisa que faria falta à estrutura atual do grupoa, com as dificuldades que o grupo passa para se manter após perda de patrocínios estatais históricos como a Petrobrás, que desde 2015 corta paulatinamente suas subvenções artísticas.

Como exemplo dessa discrepância na finalidade do financiamento cultural, temos o Fundo Nacional de Cultura (FNC) que deveria ter o papel de apoiar projetos em regiões com menor capacidade de captação de recursos, a partir de projetos apresentados para as Secretarias municipais e estaduais - ao menos $40 \%$ de recursos do Fundo devem ser repassados pelo Sistema Nacional de Cultura -, além de incentivar projetos culturais sem apelo comercial. Mas, em virtude dos baixos recursos disponibilizados graças aos seguidos contingenciamentos do montante previsto anualmente no Orçamento Federal (entre trezentos e quatrocentos milhões de reais anuais), o Fundo não tem cumprido integralmente seu papel.

O próprio MinC parecia, enquanto ainda esteve no organograma federal até 2019, ignorar que o artigo 216-A, da Constituição Federal (BRASIL, 1988), que institui o Sistema Nacional de Cultura, determina em seu parágrafo primeiro, inciso XII, que haja uma “(...) ampliação progressiva dos recursos contidos nos orçamentos públicos para a cultura" 356 , e não sua redução ou realocação. A Secretaria de Cultura que substituiu o MinC nesta legislatura tampouco parece se interessar em defender tal lei basilar para sua atuação. Esse movimento que faz com que o Estado se retraia em relação a seu papel histórico no fomento às artes, sem que a iniciativa privada cubra as demandas reprimidas e não atendidas pelos órgãos governamentais, foi muito bem descrito por Benjamin Seroussi deixando claro as conseqüências deste "vazio institucional", ao dizer que:

${ }^{356}$ Cf: BRASIL. Constituição (1988). Emenda Constitucional n. 71, de 29 de novembro de 2012. Acréscimo ao artigo 216 da Constituição Federal, denominado 216-A. Disponível em: <https://www.jusbrasil.com.br/topicos/27996471/artigo-216a-da-constituicao-federal-de-1998> Acessado em 19 de agosto de 2019 
Artistas, iniciativas, equipamentos culturais, produtores e o próprio poder público vivem em uma guerra desigual pelos recursos das mesmas empresas doadoras ou dos editais (onde) o poder público demanda ao setor cultural que se organize sozinho para então sugerir suas próprias politicas - que ajudam a desorganizar esse setor - como sugestões que serão engavetadas em seguida. Sem condições de planejar suas próprias atividades, e menos ainda de propor um planejamento para o setor como um todo, todos saem precarizados. ${ }^{357}$

Ao se pensar na falta de "iniciativa privada pura" nas artes cênicas atuais, Luiz Carlos Prestes Filho, considerado um dos pioneiros brasileiros nos estudos da economia da cultura, afirmou sobre a existência ou não de um "mercado" teatral brasileiro dizendo que ele não poderia ser considerado como tal no país “(...) simplesmente porque não há investimento e não há lucro a ser reinvestido e também dividido entre os stakeholders, ou seja, os acionistas da empresa investidora" ${ }^{\text {} 358}$. Podemos assim resumir o conceito de "economia da cultura" como "(...) a aplicação da teoria e das ferramentas da economia à análise da organização econômica do setor cultural (artes cênicas, artes visuais, patrimônio, indústria cultural) e o comportamento daqueles que produzem e consomem bens e serviços culturais, incluindo (em sua análise) o papel do governo." ${ }^{359}$, pensandoa pelo encadeamento de diferentes setores da economia que seriam impactados pelas diversas ações culturais, e é nesse contexto que manifestações como o teatro são colocadas abaixo de outras consideradas de reverberação maior e retorno mais imediato.

Tal interpretação do conceito de "economia da cultura" se baseia nas chamadas “doenças dos custos" de William J. Baumol, economista estadunidense morto em 2017, que escreveu o livro "Performing Arts: The Economic Dilema" (Artes Performáticas: o Dilema Econômico), publicado por Baumol e William Bowen em 1965 e que se tornou referência para a discussão dos gastos culturais. A partir de uma relação estabelecida entre a produção de bens industriais com a de bens culturais, Baumol afirmou que os bens culturais tenderiam a custar muito mais que os industriais por não haver "incremento da produtividade" a partir da sua execução.

\footnotetext{
${ }^{357}$ SERROUSSI, Benjamin. Dependências Táticas; in: Revista Select. São Paulo, n.39, jun./jul./ago.2018, p. 40-1

358 apud FRIQUES, 2016, p. 183

359 MARTOS; QUINTERO, 2011, p. 196. Original em espanhol
} 
Essa afirmação tem como base uma atualização da teoria de Adam Smith em que Baumol considerava que o estágio final do capitalismo seria a substituição de homens por máquinas dentro do campo industrial. Como isso não acontece nas atividades culturais - e em áreas sociais correlatas como a saúde e a educação -, seus custos apenas aumentariam indefinidamente graças à alta especialização exigida para essa função demandando salários cada vez maiores a seus executores para compensar sua formação, como explica Ronaldo Fiani:

O problema da doença dos custos é que os salários tendem a aumentar com o tempo na mesma proporção em todas as atividades da sociedade, mesmo naquelas em que a produtividade cresce muito devagar. Como os salários crescem na mesma proporção, mesmo nas atividades em que a produtividade cresce mais devagar, o custo destas últimas aumenta em relação ao custo das atividades em que a produtividade cresce mais rapidamente - como as atividades industriais. ${ }^{360}$

Isso de certa forma explica a impressão de muitos dos que viveram a consolidação do teatro profissional no Brasil da década de 1950 em diante, em que se pensava que antes a máquina teatral era "mais simples" por teoricamente exigir menos investimento em sua produção e execução. E que então ela se pagaria por eventuais empréstimos bancários, fossem eles tomados por pessoas físicas ou jurídicas, com o que se recebia via bilheteria quando de uma temporada de sucesso.

O ator Paulo Autran disse exatamente isso em sabatina em novembro de 2005 no Teatro Folha ${ }^{361}$ ao culpar as leis de incentivo como a Rouanet pelo fato dessa produção estar mais cara, fazendo com que mesmo a equipe técnica e a infraestrutura tivessem seu custo aumentado de forma "astronômica", consequentemente aumentando assim o valor dos ingressos - que ele considerava ainda "baratos" em média se comparado a outros países, mesmo reconhecendo que eles eram de custo proibitivo para a realidade salarial média brasileira.

\footnotetext{
${ }^{360}$ FIANI, 2013, Online. Disponível em: <http://www.revistacarbono.com/edicoes/04/> Acessado em 18 de agosto de 2019

361 “Autran não perdoa ninguém e agrada a todos", in: Folha de S. Paulo, 30 de novembro de 2005, Disponível em: <https://www1.folha.uol.com.br/fsp/ilustrad/fq3011200506.htm> Acessado em 18 de agosto de 2019
} 
Da mesma forma, a atriz Marly Marlei lamentava-se do fato de ser inviável, para os parâmetros pós-Lei Rouanet, a produção de espetáculos de grande porte como as que os teatros de revista faziam para mais de mil pessoas, algo comum em São Paulo na primeira metade do século XX. Em entrevista para a professora e pesquisadora Neyde Veneziano, Marlei declarou a respeito:

Porque o problema todo é financeiro. Essa é a grande dificuldade para o teatro de revista voltar. Financeiramente, é inviável. O guarda-roupa de uma revista é muito caro. E tem de pagar os ensaios. E o elenco é numeroso. Tem, pelo menos 30 bailarinas e bailarinos. Precisaria ter 5 milhões de reais. Quem é que tem 5 milhões de reais na mão pra abrir a cortina? Vamos supor até que alguém tenha. Você abre a cortina. E pra manter? E pra pagar a mídia? Então é inviável. É uma pena. ${ }^{362}$

Estes parâmetros estabelecidos pelas teorias da "economia da cultura" e da “doença dos custos" são os que parecem ser predominantes em vários dos órgãos governamentais no país nos dias de hoje, onde são abraçadas e incentivadas por todos os que ocupam a cadeira principal de seus organogramas. Essas teorias são preconizadas por economistas que insistem na retórica de "cortar gastos" que consideram supérfluos ou desnecessários.

Essa sanha de equipes econômicas é levada a cabo por executivos de diferentes matizes ideológicas, mas que no atual contexto de padronização neoliberal estão definitivamente com o pensamento e a prática em voga. Vide como exemplo dessa política a PEC 241/55, promulgada no fim de 2016 limitando o crescimento de gastos governamentais exatamente nessas áreas sociais sensíveis como saúde, educação e cultura pelos próximos 20 anos. São estes os mesmos que relegam o teatro que não dá o esperado retorno financeiro imediato aos financiadores a um estado "marginal" dentro da atual economia de mercado.

Porém, há de se destacar as tentativas de se construir um discurso contrahegemônico em relação a essas leituras econômicas sobre o fazer teatral. Nesse sentido, é importante destacar o pensamento de Bernardo Furtado Nunes - economista do Banco Nacional de Desenvolvimento Econômico e Social (BNDES) e especialista

${ }^{362}$ VENEZIANO, 2006, p. 298 
em economia da cultura -, que em sua análise da teoria de Joseph Schumpeter ${ }^{363}$ em contraposição à "doença dos custos" de Baumol, “(...) avalia criticamente os pressupostos da lei de Baumol (ao) considerar a teoria neoschumpeteriana e não mais uma abordagem teórica neoclássica (ligada à escola de Adam Smith) para avaliar adequadamente a inovação no campo das artes cênicas" (apud FRIQUES, 2016, p. 189). Nesse sentido, é importante ressaltar que tais teorias podem ou não ser aplicadas a um grupo teatral por não ser uma condição irrestrita o fato de que eles estão ligados ou não a uma lógica capitalista a determinar sua permanência ou subsistência, ainda que o campo do gerenciamento de projetos ${ }^{364}$ seja algo a ser dado mais valor como um norte para a manutenção da proposta de um grupo teatral, tanto ou mais do que os modos como este será financiado.

Pensando na adequação dessas teorias liberais dentro do fazer teatral brasileiro, tanto no passado como no presente, não é demais colocar aqui um pouco de como essa situação em nosso teatro pode ser comparada a de outros sistemas teatrais mundo afora. Nesse sentido, há diversos exemplos, correspondências e discrepâncias a serem postos em relação a como se constroem essas redes e pontes entre o meio teatral e o setor público/privado em países com estágio de desenvolvimento diverso do Brasil, assim como naqueles que também estão em um estágio semelhante ao nosso.

Fica evidente a questão do quanto essa estrutura se assemelha (em grande parte) àquela com a qual se costuma fazer teatro no Brasil. Porém, a razão de ser destacado por Celentano o fato de que esta classificação e seus dados se referiam basicamente a como o sistema teatral argentino se estruturava até o início dos anos 2000 é que se atribuem a partir de então várias misturas na condução dessas três instâncias (teatro privado, público e independente) quanto ao aproveitamento de modos de realizar espetáculos que seriam predominantes apenas em um ou outro segmento. Ou seja, peças e atores que entravam no circuito privado passaram a ser vistas também nos teatros públicos;

\footnotetext{
363 Joseph Schumpeter, economista, administrador e professor austríaco da primeira metade do século XX ligado à Escola Histórica, cuja teoria do ciclo econômico representou uma virada fundamental para a ciência econômica contemporânea, ao valorizar a inovação como fator de desequilíbrio econômico. Cf. em: PAIVA; CUNHA; MOURA JR.; SOUZA JR.; CONSTANTINO. Inovação e os efeitos sobre a dinâmica de mercado: uma síntese teórica de Smith e Schumpeter. In: Revista Interações, Campo Grande, MS, v. 19, n. 1, p. 155-170, jan./mar. 2018. Disponível em: <http://www.scielo.br/pdf/inter/v19n1/1518-7012inter-19-01-0155.pdf> Acessado em 19 de agosto de 2019

${ }^{364}$ Grifo de Manoel Friques (2016, p. 189), ao comentar a abordagem de Bernando Nunes sobre os fatores econômicos que movem os grupos de artes cênicas
} 
financiamento público passou a cada vez mais entrar no orçamento de peças em espaços privados e até de independentes; e espaços comerciais também se deram ao "luxo" de se permitirem algumas experimentações típicas dos outros dois segmentos.

O teatro dos anos 1990 em diante trouxe, como descrito por Marcelo Bones, “(...) um forte movimento (...) provocado pela redemocratização do país, incitando um desejo de conhecer outros movimentos teatrais tanto nacionais como internacionais, bem como a criação de novos modelos de financiamento a eventos culturais" ${ }^{365}$, destacando-se também que na América Latina grandes festivais ainda em atividade foram criados nessa década, como o Festival Internacional de Santiago (1994) e o Festival Internacional de Teatro de Buenos Aires (1997).

Esses movimentos coincidem com uma revalorização do trabalho do teatro de grupo que parecia haver se perdido desde um primeiro período de aglutinação de grupos a partir de uma perspectiva coletiva, que se deu até os anos 1960 e 1970, e que no Brasil ajudou na formação de companhias que se mobilizam junto aos órgãos públicos e privados por leis de fomento e políticas públicas para suas atividades. De acordo com Silvana Garcia, dando exemplos do desenvolvimento do teatro de grupo em outros países latinoamericanos como Chile e México, esse tipo de reação:

“(...) coincide com o início das ditaduras militares, vinculando (a atividade teatral) a uma atitude de resistência, militância politica e busca de uma linguagem mais popular como recusa a um teatro de perfil mais comercial (por essas manifestações serem parte de) uma onda universal de contracultura, que acontece também na Europa e nos Estados Unidos, mas que na América Latina adquire características próprias pela força do teatro político e militante em nossa região. "366

Ao se buscar novos meios associativos que congregassem artistas com esse pensamento em comum, pensou-se em um modelo de uma nova forma de financiamento que garantisse uma gestão externa diferente da Lei Rouanet e do ProAC, e que se provasse mais democrático e pulverizado nos contemplados e no manejo dos recursos.

\footnotetext{
${ }^{365}$ BONES, Marcelo. Um Olhar Sobre os Festivais. In: Observatório dos Festivais, 2017. Disponível em: $<$ https://www.festivais.org.br/single-post/2017/05/15/Artigo-Um-Olhar-sobre-os-Festivais--porMarcelo-Bones> Acessado em 18 de agosto de 2019

${ }^{366}$ GARCIA, 2012. Disponível em: <https://www.sescsp.org.br/online/artigo/6341_TEATRO+EM+ASCENSAO> Acessado em 18 de agosto de 2019
} 
Isso acabou se refletindo em uma percepção de que o teatro brasileiro parece sempre ter estado em uma posição desprestigiada, e de alguma forma até marginal, em relação a outras manifestações artísticas quanto às políticas culturais de apoio ou patrocínio trabalhadas por entes públicos e privados. Empresas que "investem" em uma montagem ou companhia geralmente pensam no retorno financeiro, assim como nas isenções e incentivos fiscais que o espetáculo o qual patrocinam poderia lhes render, além de uma exposição de certa maneira positiva de sua marca ${ }^{367}$.

E do lado do setor público, o fato de que o poder do teatro como arte viva traz em si um grande potencial mobilizador, faz com que o mesmo permaneça sempre em estado de "atenção" quanto a subvenções e incentivos. Sempre acaba-se vivendo risco de fazer com que as ações teatrais, de alguma forma, se coloquem além de onde esse controle estatal pode alcançar - ainda que mesmo nos dias de hoje raramente esse poder tátil sobre o público seja utilizado em prol de uma reflexão em prol de uma agenda coletiva.

A partir disso, pretende-se pensar em algumas das raízes históricas para essa aparente dubiedade jamais resolvida por completo entre o que ambas as esferas do poder social e econômico de nossa sociedade - o setor privado e os órgãos públicos esperam quando eventualmente se colocam como financiadoras, incentivadoras e partícipes do sistema teatral. Integrantes do meio teatral parecem considerar a existência dessas esferas de potenciais patrocinadores a rondá-los de forma a apenas fingirem prescindir de seus apoios posteriormente. Isso apesar destes também se voltarem ao teatro o tempo todo para, desse modo, legitimarem seus "investimentos sociais" ou mostrarem vínculo com esse mesmo setor da sociedade.

Sem pretender demonizar ou deslegitimar nenhuma dessas formas de apoio do "mercado" ou do poder público ao teatro, é preciso pensar no quanto esse tipo de codependência entre eles e o meio teatral afeta o modo de gestão de tais recursos ou a produção de obras teatrais em trabalhos de grupos para que a experiência teatral possa ser a mais rica e livre possível. Mas, para entrarmos nessa perspectiva histórica sobre como chegamos até este aparente círculo vicioso, cabe situar brevemente a situação do

${ }^{367}$ Cf. na p. 251 
financiamento teatral brasileiro nos dias atuais para assim situar melhor a condição paulistana e ilustrar melhor o que se intenciona tratar aqui.

Hoje o setor público pode ser considerado como o principal financiador de iniciativas teatrais no país, desde pelo menos a promulgação da Constituição Federal de 1988, que em seu artigo 215 (BRASIl, 1988) coloca a cultura como um “(...) direito fundamental de segunda geração (onde) a prática de posturas positivas em prol de sua efetivação e universalização" ${ }^{\text {368 }}$ é incentivada pelo poder público em todas as suas esferas (federal, estadual e municipal). Com isso, após a criação do MinC em 1985 deuse um maior respaldo para as políticas de outras estruturas públicas nas Secretarias municipais e estaduais, para que a partir disso elas passassem a contar de maneira mais permanente com estruturas para mapeamento e atendimento às demandas culturais da sociedade através desses mecanismos de incentivo direto ou indireto.

Por financiamento direto, há maneiras de se obter acesso a financiamento público por meio de secretarias ligadas a administrações federais, estaduais e municipais através de editais e prêmios. Editais do poder público, como os do PROAC e de empresas privadas ou estatais, como os dos programas Rumos (do Itaú Cultural) e Petrobrás Cultural, seriam como concursos periódicos abertos por tais entidades para prover recursos a projetos e iniciativas de residência artística, e pesquisa e produção de espetáculos, podendo assim fazer com que recursos cheguem de forma mais capilar a diversas regiões e variadas iniciativas. Esse também é considerado o mais próximo de uma tentativa de um padrão buscado por entes externos ao meio artístico do país na busca de sistematização técnica e "excelência" artística para desenvolvimento de espetáculos originais.

Em relação ao poder público, existe hoje uma enorme gama de premiações administradas por órgãos como FUNARTE e Secretarias de Cultura do Estado e da Prefeitura de São Paulo que abarcam diversas linguagens e projetos de companhias em diferentes estágios de desenvolvimento interno de pesquisa e produção. A diferença quanto aos prêmios e editais públicos e os oferecidos pela iniciativa privada se dá pelo

\footnotetext{
${ }^{368}$ NATARELLI, Talita. A Cultura do Povo e Para o Povo: Direito Fundamental Erradicado. In: Portal Educação, Online, 2012. Disponível em: <https://www.portaleducacao.com.br/conteudo/artigos/direito/cultura-direito-fundamentalerradicado/22915> Acessado em 18 de agosto de 2019
} 
fato destes últimos serem mais específicos em suas demandas, porém generalistas quanto às linguagens que cada premiação abarca. Para dar um exemplo, um prêmio da iniciativa privada pode oferecer um grande prêmio para projetos teatrais sem se preocupar em separar em seu edital ou prêmio expressões artísticas como dança, teatro e circo, enquanto as exigências organizativas para cada grupo acabam sendo as mesmas. Em contraposição a isso, é muito mais comum que no poder público haja editais e prêmios específicos para cada linguagem artística em separado.

Com isso, apesar de aparentemente haver uma articulação entre muitas dessas iniciativas pelo fato delas atingirem objetivos comuns, um exemplo de um dos poucos modelos de integração de políticas entre vários entes parece ser o dos Pontos de Cultura, proposta de Celio Turino quando na Secretaria de Cidadania Cultural do MinC em 2004, que entre outras ações atua no mapeamento de centros de importância local para reconhecimento de seu trabalho de excelência na promoção cultural em suas comunidades e além dela. Esse programa congrega em si muitos parâmetros utilizados pela chamada Política Nacional de Cultura Viva (do governo federal) no incentivo à manutenção desses centros e construção de políticas estaduais e municipais para garantir sua atuação.

A Política Nacional de Cultura Viva, tornada Lei 13.018 em abril de 2014 após já ter sido introduzida pelo MinC desde 2004, permitiu esse reconhecimento e integração com seu artigo que garante “(...) estimular iniciativas culturais já existentes, por meio de apoio e fomento da União, Estados, Distrito Federal e Municípios”, fazendo com que após projeto piloto na cidade de Campinas (onde foi implantado em 1990), as Secretarias de Cultura do Estado e da cidade de São Paulo passassem a utilizar dessa ideia de possibilitar repasse de recursos de forma mais desburocratizada. Isso se deu muito pelo pensamento inicial na concepção do programa de se colocar “(...) quanto (o poder público) pode oferecer para, a partir disso, os proponentes definirem como aplicarão os recursos a partir de seu ponto de vista e suas necessidades"369, que é algo diferente de prêmios e editais que colocam antecipadamente uma proposta de execução a qual os grupos proponentes devem se adequar.

${ }^{369}$ TURINO, 2017, p. 63-4 
Esse conceito de "cultura viva" trabalhado como política pública se completa perfeitamente no que foi colocado durante a gestão da Secretaria de Cultura Municipal por Marilena Chauí (1995) como "cidadania cultural”, onde o Estado não seria indutor de determinadas atividades culturais, mas devia saber “(...) diferenciar entre estadismo cultural (cultura oficial) e dimensão pública da cultura (o Estado estimula a criação cultural da sociedade) ${ }^{\natural 370}$. Seu trabalho como Secretária de cultura acabou norteando todos os conceitos de direitos culturais a serem considerados por gestões progressistas e social-democratas. Tais direitos podem ser resumidos nos tópicos a seguir:

- $\quad$ Direito de acesso e de fruição dos bens culturais por meio dos serviços públicos de cultura (bibliotecas, arquivos históricos, escolas de arte, cursos, oficinas, seminários, gratuidade dos espetáculos teatrais e cinematográficos, gratuidade das exposições de artes plásticas, publicação de livros e revistas, etc.), enfatizando o direito à informação, sem a qual não há vida democrática;

- Direito à criação cultural, entendendo a cultura como trabalho da sensibilidade e da imaginação na criação das obras de arte e como trabalho da inteligência e da reflexão na criação das obras de pensamento; como trabalho da memória individual e social na criação de temporalidades diferenciadas nas quais individuos, grupos e classessociais possam reconhecer-se como sujeitos de sua própria história e, portanto, como sujeitos culturais.

- $\quad$ Direito a reconhecer-se como sujeito cultural, graças à ampliação do sentido da cultura, criando para isso espaços informais de encontro para discussões, troca de experiências, apropriação de conhecimentos artísticos e técnicos para assegurar a autonomia dos sujeitos culturais, exposição de trabalhos ligados aos movimentos sociais e populares.

- Direito à participação nas decisões públicas sobre a cultura, por meio de conselhos e fóruns deliberativos nos quais as associações artísticas e intelectuais, os grupos criadores de cultura e os movimentos sociais, através de representantes eleitos, pudessem garantir uma política cultural distanciada dos padrões do clientelismo e da tutela. ${ }^{371}$

Contudo, tais conceitos podem ser norteadores, mas também podem ser redirecionados por questões alheias às práticas de governo e de Estado. Apoios financeiros privados, mas também os editais e prêmios públicos, se baseiam sobre especificidades para participação de determinados entes e expressões artísticas, que

${ }^{370}$ CHAUÍ, Marilena. Cultura Política e Política Cultural. In: Revista Estudos Avançados, v. 9, n. 23. São Paulo: USP, 1995, p. 82

${ }^{371}$ Ibid., p. $82-3$ 
limitam qualquer intenção de uma maior abrangência deste norteamento. Isso se dá, por exemplo, nas políticas de entidades próprias para gestão e execução de iniciativas cênicas como as OS, que trabalham desde a criação até a produção de espetáculos em centros culturais cuja administração lhes é outorgada pelo poder público - no Estado de São Paulo, a atuação delas junto à Secretaria de Cultura do Estado vem desde 1998 -, através de lei que complementou a atuação dessas "entidades jurídicas organizadas pela sociedade civil sem fins lucrativos" em atividades de formação e promoção da cultura. Com isso, eles podem seguir diretrizes colocadas pela secretaria de estado, como também podem ir por outra direção. .

Com as OS controlando a gestão de centros de produção e formação em artes cênicas, como as Oficinas Culturais, grupos que queiram ter algum vínculo com o espaço administrado pela entidade devem se adequar à mesma legislação que dá entrada nesses espaços apenas para "entidades jurídicas", ou seja, proponentes que apresentem constituição jurídica para realização da atividade a que se propõe, nesse caso o teatro. Isso também se dá com o ProAC ICMS, mas de uma forma ainda mais limitante ao se aceitar a participação de entidades "independentes" constituídas juridicamente de forma desvinculada de órgãos cooperativos e associativos para que possam encaminhar processos para usufruir dos incentivos fiscais do Estado.

Tais exigências feitas por entidades como as OSs ou as secretarias torna um tanto precário e incerto qualquer planejamento que tenha de levar em conta o recebimento desses recursos para manter as atividades regulares de um grupo de teatro de maneira saudável, pois mesmo para os que acabam "habilitados" a receber tais recursos através dos editais, esse pagamento acaba muitas vezes condicionado aos humores políticos. Foi o que ocorreu no Fomento ao Teatro em 2018, suspenso por ação unilateral do secretário municipal André Sturm após contestações sobre seguimento das regras propostas no edital, e da Bolsa para Formação e Residência da FUNARTE, suspensa desde 2016. No caso do Fomento, grupos de larga atuação em pesquisa e formação como o Pessoal do Faroeste se vêem ameaçados de perder sua sede por este pagamento estar condicionado ao recebimento de verbas do Fomento.

Visto isso, a iniciativa do MinC de criar em 2013 o Sistema Nacional de Informação e Indicadores Culturais (SNIIC) como uma plataforma colaborativa, tanto 
para as demandas quanto para suas possibilidades de atendimento, contribuiu muito para a integração de dados e implantação de muitas das políticas atuais com o advento dos Mapas Culturais em âmbito local. Em São Paulo, a plataforma SP Cultura, utilizada até hoje para o recebimento dos projetos dos diversos editais da prefeitura, funciona a partir disso. Apesar de também ser um local que dá acesso ao público sobre as iniciativas culturais em áreas determinadas da cidade, ela acaba sendo mais utilizada por quem é do meio teatral para conhecimento dos profissionais e espaços de forma atualizada.

Outro meio bastante usado para se obter recursos de financiamento teatral é o financiamento de caráter misto, como a Lei Rouanet ${ }^{372}$, através de incentivos fiscais captados diretamente com empresas com a chancela do poder federal, que desconta de impostos devidos ao Tesouro por essas empresas patrocínios direcionados a iniciativas culturais escolhidos por ações próprias dessas empresas. Apesar de muitas vezes ser considerada tão somente como mero uso de recursos públicos, ela não se diferenciaria muito da tradicional busca por captação de patrocínios levada a cabo desde tempos antigos na cultura brasileira, tendo como diferencial esse "bônus" da anuência e aval do MinC para avalizar o projeto por ela habilitado como apto a receber tais incentivos fiscais segundo os valores considerados ideais pela produção do espetáculo.

Apesar disso, tanto os prêmios e editais quanto os incentivos fiscais dão a sensação de direcionar todo o modo de produção artística a uma lógica de construção de projetos anuais própria da administração de entidades e fundações, afinal a grande maioria desses meios de captação de recursos acabam por seguir uma mesma cronologia que deixa quem não consegue patrocínio por eles praticamente sem guarida alguma, fazendo com que mesmo projetos de captação de recursos de entidades privadas via leis de incentivos fiscais para financiamento de projetos, como o Rumos Itaú Cultural, também se pautem dessa forma. O Rumos, por exemplo, distribuiu quinze milhões de reais ao ano em seu programa de incentivo às artes no ano passado, usando para isso boa porcentagem do captado pela instituição via incentivos fiscais, um meio que recebe críticas por ser majoritariamente utilizado por instituições culturais no planejamento anual de suas atividades, chegando apenas indiretamente a grupos "menores" ou pessoas físicas.

${ }^{372}$ A lei 8.313/1991 que criou o Programa Nacional de Apoio à Cultura previa vários mecanismos de incentivo; um deles era a Lei Rouanet, batizada em homenagem a Sergio Paulo Rouanet, onde empresas e pessoas físicas poderiam descontar do Imposto de Renda valores repassados a iniciativas culturais. 
Os órgãos públicos tampouco estão alheios a esses paradigmas. Segundo o relatório do Fórum Brasileiro de Direitos Culturais, o montante de recursos alocados pelas estatais federais foi reduzido de $22,3 \%$ a apenas $12,6 \%$ dos recursos utilizados pela lei em um período de 4 anos entre 2010 e 2014. E ainda assim, tudo que também se propõe a fazer a respeito disso é diminuir ainda mais esse montante com cortes no programa Petrobras Cultural e nos patrocínios culturais da estatal, que somaram juntos trinta e oito milhões de reais em $2018^{373}$. Tais cortes atingem em cheio grupos com uma trajetória de pesquisa continuada que recebiam recursos da estatal, como o Teatro Oficina Uzyna Uzona e o Teatro da Vertigem sem, no entanto, ter havido um detalhamento público da parte de quem propõe esses cortes sobre como levar a cabo a propalada intenção de fazer esses recursos chegarem a "artistas menos conhecidos".

Visto que nenhuma das iniciativas aqui apresentadas é de acesso universal e que todas elas denotam alguma competição pelos recursos entre os que serão habilitados e inabilitados em cada processo, a concentração de recursos e projetos contemplados acaba sendo um grande entrave para essa nova modalidade de "mecenato". No caso da Rouanet, por exemplo, deve-se levar em consideração a diferença que existe entre "recurso apresentado", "recurso aprovado" e "recurso apoiado".

"Recurso apresentado" é a verba que é colocada como teto de investimento externo pela produção do espetáculo em seu projeto de captação que almeja ser aprovado pela comissão responsável pela Rouanet no MinC, enquanto "recurso aprovado" é o quanto essa comissão do MinC avalia ser efetivamente necessário ou pertinente para a montagem do espetáculo ou concretização do projeto, considerando as demandas apresentadas e a comparação com projetos similares. Importante frisar que, desde que a lei entrou em vigor em 1993, apenas perto do início de sua vigência, em 1995, e em 2017 esses dois valores eram coincidentes, sendo que sempre o valor "aprovado" pelo MinC era bem menor que o "apresentado". O "recurso apoiado" seria então o que foi efetivamente captado pelos proponentes do projeto, e investido pelas empresas nas reuniões posteriores à aprovação no MinC.

\footnotetext{
373 AMORIM, Daniela; NUNES, Fernanda: "Petrobrás avalia cortar patrocínios culturais", in: O Estado de S. Paulo, 07 de fevereiro de 2019. Disponível em: <https://politica;estadao.com.br/noticias/geral, petrobras-avalia-cortar-patrocinios-culturais.70002711112> Acessado em 19 de agosto de 2019
} 
E nisso há um verdadeiro abismo: em 2017, ano com o maior montante histórico de investimento pela lei, a diferença entre o valor total aprovado para captação (pouco mais de seis bilhões de reais) e o efetivamente captado (cerca de um bilhão e duzentos milhões) foi de $80 \%$. Dentre os recursos efetivamente investidos pela Rouanet, o segmento das Artes Cênicas recebeu 37,93\% de todos os recursos captados em 2017, sendo esta a área artística com maior dotação de recursos oriundos da lei no referido ano. Contudo, além dessa classificação por parte do MinC englobar todas as linguagens passíveis de expressão cênica em sua produção (como dança, teatro, circo), além de eventualmente atividades correlatas que também fazem uso de elementos cênicos (como escolas de samba) - ou seja, usando a mesma lógica de classificação das atividades artísticas dos prêmios de incentivo da iniciativa privada - essa classificação acaba se mostrando distorcida e não revela o alto grau de concentração de seus recursos, com quase $50 \%$ deles restritos a produções no Estado de São Paulo.

É preciso também considerar os subgêneros dentro das próprias Artes Cênicas que ganham maior visibilidade para investimento privado. Nesse quesito, o principal deles é o chamado gênero musical, que se diferencia das produções originais brasileiras vindas desde o século XIX pela estética calcada em versões de espetáculos da Broadway ou em produções inspiradas nestas. Esse gênero passou a se tornar um grande nicho de mercado a partir do ano 2000, e hoje ele gera em média 100 empregos diretos por montagem dentro dessa linha de produção, além do trabalho cada vez maior de escolas especializadas no gênero.

Nesse sentido, no campo das Artes Cênicas a Lei Rouanet acaba atendendo poucas produções que demandam um maior esforço e dispendimento em sua execução, como as já mencionadas escolas de samba além, por exemplo, dos musicais. Muitas vezes essa situação deixa produções menores sem possibilidade de captação junto a empresas, por não poderem competir com produções maiores na visibilidade a ser oferecida a empresas por este apoio. Dentre os doze projetos de maior valor captado em 2017, apenas dois eram de Artes Cênicas - e ambos eram musicais: "O Fantasma da Ópera”, com onze milhões e cem mil reais, e "A Pequena Sereia", com nove milhões e seiscentos mil reais. Neste último, os recursos da lei foram responsáveis por $90,6 \%$ de todo o seu orçamento. 
Além do mais, o fato de renúncias fiscais não serem algo exclusivo para o atendimento de empreendimentos e iniciativas culturais faz com que talvez se desconsidere as outras possibilidades de financiamento indireto. Relatório do Forum Brasileiro pelos Direitos Culturais (2016), uma rede colaborativa que reúne mais de 100 entidades representativas do mundo da cultura no país, aponta que os investidores da Lei Rouanet são majoritariamente grandes empresas brasileiras, pois a limitação legal de que somente empresas que apuram seu Imposto de Renda pelo sistema tributário de lucro real possam utilizar o incentivo fiscal da Lei Rouanet impede que médias e pequenas empresas entrem no sistema.

João Leiva, diretor da J.Leiva, consultoria especializada em cultura e esporte, publicou em novembro de 2018 um levantamento da atividade teatral no país onde ressalta que são as empresas de lucro presumido - isto é, que calculam sua tributação devida através de variações trimestrais de seu lucro - as que teriam maior potencial para renúncias fiscais a projetos de porte médio e pequeno, com perfil diferente do que é atendido hoje pela Lei Rouanet, onde a quantidade de empresas que entraram no sistema do mecenato tem se mantido estável em pouco mais de três mil.

Contudo, como a proposta de "mudança" na Rouanet do novo governo aventoucom a interrupção de chamadas para novos projetos - ao menos em janeiro de 2019 - e diminuição do teto de recebimento possível para projetos da lei (de sessenta milhões para dez milhões de reais) sem considerar que desde o seu início nenhum projeto sequer chegou perto desse valor máximo. Dos quinze projetos que historicamente mais receberam recursos da lei apenas um deles não era referente à administração, manutenção ou reforma de edifício ou instituição cultural, geralmente de caráter privado - uma demanda, portanto, bem diferente e muito mais complexa do que um único projeto cultural a ser atendido pela lei:

\begin{tabular}{|c|c|c|}
\hline \multicolumn{3}{|c|}{ MAIS CAROS PROJETOS DA ROUANET EM REAIS - 1993-2018 } \\
\hline $\begin{array}{l}\text { Fundação Roberto } \\
\text { Marinho }\end{array}$ & $\begin{array}{l}\text { Museu da Imagem e do Som-RJ } \\
-2010\end{array}$ & 36,2 milhões \\
\hline $\begin{array}{l}\text { Ass.Amigos } \\
\text { Teatro Municipal RJ }\end{array}$ & $\begin{array}{l}\text { Reestruturação Interna - } \\
\text { Teatro Municipal - } 2008\end{array}$ & 35,6 milhões \\
\hline Itaú Cultural & \multicolumn{2}{|c|}{$\begin{array}{ll}\text { Plano Anual de Atividades } & 7 \text { vezes }\end{array}$} \\
\hline $2009-30,6$ milhões & $2007-27$ milhões $\quad 2002-$ & $2002-22,1$ milhões \\
\hline 2011 e $2008-29,5$ milhões & 2010 - 26 milhões & $2012-22$ milhões \\
\hline
\end{tabular}


Visto os projetos que receberam mais recursos também serem de locais que pediriam por reformas ou melhores condições de conservação, sendo um deles o Teatro Municipal do Rio de Janeiro, é um tanto triste considerar que não houve antes iniciativa de nenhuma organização que tenha pensado na possibilidade de apresentar um projeto em prol do $\mathrm{TBC}$, visto que os valores relatados vão muito além do que era originalmente pedido para a finalização da reforma no teatro. No que se pode concluir que a maioria da iniciativa privada de hoje não pensa mais como um dia já o fez.

O mapeamento dos marcos regulatórios, com o consequente conhecimento da totalidade dos mecanismos para entrada de dinheiro oriundo de empresas ou impostos indiretos no setor cultural, também traria consigo uma resolução para essa dubiedade de se lidar com meios conhecidos e experimentados de financiamento como a lei Rouanet, que porém não parecem ser ainda totalmente compreendidos, e o comodismo dos entes governamentais em assumir compromissos de longo prazo sem tanto risco. Talvez seja também esse um dos motivos para a permanência dessa lei apesar de tantas mudanças na gestão do MinC, pois é difícil que não tenha se dado conta do quanto tal estrutura parece ainda insuficiente para o atendimento das demandas gerais, e direcionada sobretudo para as necessidades de gente dita "célebre e diferenciada". 


\section{CONCLUSÃO}

Desde muito tempo, o teatro brasileiro pode ser considerado, tanto a partir de uma perspectiva sobre a sua produção moderna ou contemporânea como antes delas, como um elemento algo disforme que parece buscar unidade na consolidação de sua linguagem perante o público, assim como na maneira como pensa gerir esse sistema. Ainda que se respeite e admire os diversos modos de expressão do nosso teatro, a arte teatral brasileira é vista pela pelos agentes públicos e privados da sociedade - incluindo a sociedade civil, os órgãos públicos e os representantes de empresas privadas -, como um elemento único a quem se avalia estar indo bem ou mal no resultado de suas expressões conforme parâmetros de mercado seguidos pelos investidores.

Tais parâmetros podem estar condicionados a determinado contexto histórico, mas em relação a como se gestiona um grupo de teatro não há muita diferença ao se falar de inúmeras iniciativas da primeira metade do século XX, como a companhia sediada no TBC, em relação a grupos que são seus contemporâneos ainda que tenham atravessado outros períodos históricos, como o Teatro Oficina, ou mesmo aqueles que se formaram em processos coletivos vindos dos anos 1970 até hoje. Como tambem foi dito em relação a eles, mesmo se fossem comparados outros grupos talvez tão ou mais diferentes entre si do que os apresentados, seria muito provável que também esses outros grupos tivessem recebido recursos do poder público em algum momento de suas atividades, conforme as possibilidades de cada período.

Grupos que inicialmente foram mantidos por apoios de mecenas e grandes empresários com abnegação artística, ou sobrevivendo principalmente com as rendas esparsas e inconstantes da bilheteria, poderiam ser considerados da mesma forma como de iniciativa privada, mesmo com algum dinheiro público em caixa. Se houvesse real competitividade entre eles, a partir de um sistema próprio e autossustentável para suas atividades, seria possível dizer que uma peça ou companhia "fracassou" por sua própria conta, pois ambas estariam em igualdade de condições de divulgação, estrutura, entre outros fatores. Porém, hoje é possível vaticinar que, quando um teatro definha, quebra ou fecha, o que fracassou foi todo o sistema teatral que não conseguiu mantê-lo de pé, nem com dinheiro público pelo subsídio, nem com dinheiro do público pela bilheteria. 
Estamos vivendo em um sistema econômico, de matriz capitalista e neoliberal, que coloca cada um como responsável pela sua própria sorte para prosperar ou não dentro desse sistema. A livre iniciativa de um empresário montar um teatro e prover nele todo o equipamento, mão de obra e licenças se equivaleria ao vendedor dessa mesma mão de obra, transformado desde o início dos anos 1990 em microempreendedor individual para entrar no mercado. Na verdade, liberais que colocam os dois no mesmo patamar se esquecem de considerar qual deles teria maior facilidade de acesso aos meios para prover sua iniciativa própria. Quem, por exemplo, teria crédito ou subsídio governamental para dar início ao seu projeto.

Pois é isso que está em jogo, o fato do chamado "estado mínimo" apregoado pelos neoliberais que dizem estarmos vivendo uma "era de ouro do capitalismo" ser mínimo apenas para um lado, o lado precarizado por vender sua mão de obra - no caso dos artistas, vendê-la como microempreendedor para um empresário que muitas vezes investe, ou especula, com dinheiro público. Logicamente, ainda há níveis intermediários dentro dessa hierarquia, como produtores, curadores, captadores de recursos, e outros que literalmente fazem a ponte entre os dois lados. Porém, a estrutura permanece a mesma, isso quando os que sempre foram os intermediários para fazer essas iniciativas acontecerem também não são precarizados pela alta competição entre eles.

Pensando historicamente, essa relação poderia ser vista de forma a considerar o quanto essas relações poderiam ter tomado outro rumo. O TBC, como qualquer iniciativa, teve suas fases. No final dos anos 1940, ainda amador, era o teatro universitário em estado de graça, com uma continuidade e nível de excelência até inimaginável para quem o viveu. Mas havia espaço para aprimorar. Nos anos 1950, o esplendor externo da produção, e a ascensão das estrelas desse teatro, contrastavam então com a autodestruição interna de sua estrutura original. E assim sucessivamente até o fim da companha em 1964. Não há como negar que, para a imensa maioria dos artistas que vivenciaram essa época, o TBC faz falta, como se a cada vez que nos remetêssemos a ele fosse apenas para sentir e expressar saudade, sem que haja uma nova possibilidade de ressurreição. 
Tais iniciativas históricas que impulsionaram o TBC se aliam a outras tantas iniciadas antes do teatro da Bela Vista e impulsionadas desde sua inauguração, como os grupos de estudantes, as companhias surgidas a partir de cisões dentro dos grupos maiores, e os grupos de vanguarda que tomaram a dianteira do fazer teatral em cada momento histórico. Todas elas, ao mesmo tempo que contribuíram para a diversidade do modo de fazer teatro no país, fizeram com que seus diferentes modos de produção teatral e administração dos espaços convivessem em prol da criação e estabilidade de um mercado teatral no país. Ocupados por atores, diretores e técnicos, esses teatros ajudaram a causar tamanha diversidade de estilos que qualquer tentativa de unificação de um modelo administrativo plenamente profissional pareceria algo mais utópico que as ideias que encenavam nos palcos.

Olhando em busca dos modelos de gestão teatral posteriores a essa irrupção dos anos 1940, que fizeram de tudo para não cair nas mesmas tormentas que seus antecessores, vimos que existem lições a serem aprendidas para se levar os três eixos fundamentais de uma companhia profissional total - formação, produção, exibição - de forma plena. Como frisado por Marilena Chauí (1995) no seu plano de construir o conceito de "cidadania cultural", ainda se fazia necessário construir no Brasil uma junção entre escola, equipamento cultural e universidade no provimento de artistas comprometidos com um eixo contínuo de cultura. Esse conceito fundamental para vários entes públicos, e que ajudou a fundar os preceitos da política cultural da França por gente como André Malraux no fim dos anos 1950, havia redundado na criação do TBC nos anos 1940 ao juntar o trabalho dos grupos universitários (GUT, GTE, entre outros) e a escola de formação para novos profissionais (EAD) em um mesmo equipamento, para deleite do público que pode pagar para ver isso se concretizar.

Essa junção certamente foi rara na cultura brasileira até o surgimento do TBC. Porém, mesmo o TBC sendo uma empresa teatral na sua produção e exibição de um sem número de peças, sua parceira inicial com a EAD se perdeu ainda no início de sua história, dada a limitação física e orçamentária da escola. A EAD acabou, tempos depois, por ter guarida na mesma universidade de onde seus fundadores se originaram, a USP. E mesmo que a escola ainda tenha permanecido dentro do teatro de outras formas através de seus formandos e professores realizando trabalhos no TBC, ainda assim o TBC poderia ser considerado uma das "grandes escolas práticas de teatro" no país. 
Esse ganho para o teatro naconal, no entanto, não era para todos. O TBC sempre se manteve como um dos espaços culturais mais caros de São Paulo enquanto teve sua companhia ativa. Ao mesmo tempo, por mais que tenha experimentado algum resquício de vanguarda em sua trajetória, ela era voltada para a possibilitação de que houvesse lucro para os envolvidos em sua organização. Pois, apesar de sempre alegar prestar um serviço à população e de se designar juridicamente como "entidade de fins nãoeconômicos", ela era uma empresa e como tal se portava.

Se a empresa que promoveu a abertura do teatro acabou por tomar outros rumos, isso teve a ver com decisões próprias tomadas por sua direção contra sua conjuntura. Além disso, levando a cabo a máxima que circula em muitos círculos capitalistas, onde os lucros são privatizados ao máximo para que os prejuízos sejam socializados, o TBC recorreu à salvaguarda do poder público exatamente quando se viu com difículdades para prosseguir em seu modelo de negócios tal como o concebeu quando iniciou seu processo de profissionalização. E foi o poder público que novamente o salvou de, após o fim de sua companhia fixa, se tornar um edifício com qualquer outra destinação.

A respeito da política cultural que se poderia constituir a partir daí, o que faria com que esse "modelo TBC" se replicasse por vários cantos da cidade e do país não poderia ser algo tocado em frente apenas pela iniciativa privada, visto que isso poderia fazer com que abrissem uma concorrência entre si que talvez não interessasse a ela naquele momento. Mesmo as companhias que se originaram do TBC e buscaram replicar seus métodos ou construir seu próprio modelo buscavam se associar entre si, tendo em vista que a expansão de uma companhia ajudaria a outra parte a se sustentar. Esse seria o motivo principal para se pensar que, ao fracassar o TBC, todo um modelo para o teatro naiconal teria fracassado junto.

Nesse sentido, a entrada do poder público na elaboração de políticas públicas struturais a partir do final dos anos 1950 foi fundamental para que o teatro pudesse encontrar um caminho para a expansão desse modelo inicial. Também não é coincidência que esse tenha sido o momento em que também se deu o início de uma maior efetivação de iniciativas culturais de entidades que buscavam se comprometer com uma visão mais ampla de sua atuação social e artística, como o SESC. 
Pensando nos mecanismos com que o meio teatral se coliga entre si para se reconhecer enquanto classe, ainda que uma representação única desse meio seja algo utópico, é possível pensar que essa articulação entre as necessidades dos artistas e as entidades representativas esteja um tanto dispersa. Isso não é tão verdadeiro. As entidades de classe tradicionais ainda estão aí - Cooperativa, SATED -, com suas grandes estruturas para sustentar e o peso de demandas eternas a serem atendidas. Porém, é fato de que em momentos de maior necessidade de união entre os diferentes atores dessa luta - artistas, técnicos e produtores -, como os que vivemos atualmente com a constante desregulamentação do trabalho chegando até o meio artístico através de entidades como OS e OSCIPs, pessoas ligadas tanto a equipamentos públicos (Teatro Municipal) como entidades privadas (SESC e SESI) estejam buscavam se refiliar ao sindicato e a entidades de classe.

Esse movimento, apesar de importante frente a anos de indiferença para com essas associações, ainda parece insuficiente para atingir o poder constituído mesmo com os enfrentamentos pontuais que aparecem em momentos de urgência. Nesse cenário, novas associações ainda buscam seu lugar, rendendo-se conta do trabalho que ainda há para ser feito. A ATBC, em seus dois anos de atuação em prol do TBC, parece ter avançado bastante em seus intuitos, pois primeiramente conseguiu trazer o teatro da Bela Vista para a lembrança do publico e do meio teatral, para assim incentivar um debate sobre seu destino entre artistas, intelectuais e instâncias governamentais e privadas, em meio a tantas urgências que se vivem no país desde sempre.

Este debate conseguiu gerar uma campanha de vulto que levou a instâncias de decisão nas entidades envolvidas na negociação pelo seu espaço, tanto a que estuda obter o seu legado (SESC) quando a que tem hoje o seu espólio (FUNARTE). Isso não é pouco a ser considerado. Mas a luta não termina enquanto o último bastião que tranca o portão do teatro continuar em pé, e esse também é o caso hoje, apesar dos pequenos avanços. A perspectiva de abertura do espaço deste teatro depende também de uma boa projeção de sua viabilidade enquanto negócio. Vale pensar que a ATBC, diferente das outras antigas mantenedoras do TBC, não tem capital constituído para administrar essa luta por si só, e tambem não espera, sem que haja alguma pressão, por uma ação do Estado no teatro que já está com sua obra paralisada por tanto tempo. 
O poder público, após construir suas próprias políticas por tanto tempo antes e depois dos golpes civil-militares e da democratização do país, parece ter também se acomodado a uma lógica de auxílio discriminado pelos editais e concessões, que fatalmente jamais chegarão de maneira universal a todos os pretendentes. O máximo de política artística vigente a juntar os três pilares que Chauí constituiu em seu conceito de "cidadania cultural", o CEU da Prefeitura de São Paulo, está muito aquém de suas possibilidades de uso, tanto por parte do poder público - que parece propositalmente alimentar uma burocracia monstruosa para fazer com que ele não seja ocupado com algo que fuja do seu controle - como dos artistas que não reivindicam tanto quando se poderia a plena ocupação de seus espaços.

Mesmo considerando que os espaços dos CEUs estejam nas franjas da cidade de São Paulo, portanto afeitos às próprias carências locais, políticas que poderiam atingir seu público e as comunidades onde estão inseridos tem a chance de serem perfeitamente replicadas em quaisquer lugares da cidade, mesmo porque a Bela Vista onde hoje está o TBC também é considerada uma "periferia" dentro da zona central da cidade - daí a insistência de empresários como Sílvio Santos em adensarem a região com enormes empreendimentos, para trazer ao lugar um público "diferenciado" mais condizente com suas próprias intenções comerciais.

Durante os trabalhos de constituição da $\mathrm{ATBC}$, com as visitas técnicas à região $\mathrm{e}$ ao interior do teatro para saber o estado da reforma realizada até então, os integrantes da associação sentiram uma grande necessidade do povo da região em conhecer e se integrar mais à história desse teatro e de outros locais históricos do bairro. O Oficina, por sua atuação contínua ali desde os anos 1960, certamente tem um considerável knowhow quanto a chamar a comunidade para mais perto do seu espaço. Outros teatros de companhias aqui destacadas como a do Pessoal do Faroeste, a Mungunzá e o Teatro do Incêndio (que hoje se encontra na mesma Bela Vista que o TBC) buscam fazer o mesmo. Mesmo equipamentos menores, como a Zona Franca, fazem trabalhos nesse senitdo. Portanto, é importante persistir neste tipo de envolvimento local para que o poder público e entidades privadas também valorizem essas experiências, para não irem contra as aspirações do seu público potencial. Afinal, uma comunidade defende um teatro se souber a sua história e a importância que sua presença ali traz à região. 
Esse trabalho com a comunidade local seria o grande questionamento que se poderia fazer às iniciativas anteriores de tentativa de recolocação do TBC no circuito teatral sem sua companhia fixa, após 1964 - principalmente ao projeto do Novo TBC, do início dos anos 2000. Quando Abujamra reabriu o TBC no fim dos anos 1970, conseguiu trazer a atenção da classe teatral da cidade e do país para sua intenção de reocupar o teatro, trazendo peças de várias tendências e gêneros para manter o local em constante movimento. O Novo TBC também tentou isso, porém ao mesmo tempo não pareceu se conectar ao modo teatral predominante no período, que estava se deslocando da encenação clássica de modo tão radical quanto nos anos 1960 e 1970, e não foi bem sucedido em trazer ao lugar o público que prefereria o clássico.

Talvez essa experiência do Novo TBC tenha sido flagrante de uma tendência que se revelou mais forte exatamente a partir da cena teatral que emergiu no início dos anos 2000 com o movimento Arte Contra a Barbárie. A partir dessa época, a maior pulverização das ações teatrais com temáticas mais diversas e locais ocupados para o teatro se espalhando pela cidade, acarretou uma maior liberdade de ação aos coletivos e uma democratização do acesso para públicos que se sentiam excluídos do teatro, por não se virem espelhados em peças clássicas ou mesmo modernas. Essa pulverização, porém, ainda parece se mostrar economicamente insustentável - daí, a necessidade maior de entrada do poder público para garantir essas iniciativas.

Desse maior envolvimento do poder público pode vir a junção definitiva entre as políticas para a arte teatral e as da educação, tal como preconizada por Malraux e imaginada, porém pouco seguida, pelos executivos públicos brasileiros. $\mathrm{O}$ novo projeto de reabertura do TBC contempla isso com a previsão de se fazer em um de seus espaços internos um Memorial do Teatro Brasileiro, além das possibilidade de atividades com a entidade que porventura administre o espaço. Considerando políticas nesse sentido postas em prática por entidades como o SESC, isso é algo possível de se fazer com a devida vontade política. Apesar de o SESC ser uma entidade muito bem vista hoje pela população em geral por sua atuação sócio-cultural, seu padrão de atuação não deve também ser visto como único e definitivo, podendo estar passível a sugestões e iniciativas da sociedade civil. 
Quanto a isso, a mobilização também poderia ajudar no engajametno da sociedade fazendo jus à definição da associação, para que os “Amigos do TBC" também se tornem "Do Teatro Brasileiro". Apesar da crônica falta de capital pelo fato de não haver um investidor na origem da associação, as redes e demais modos de articulação para que o movimento se torne mais presente no cotidiano dos que freqüentam o teatro e também para os que o fazem acontecer, se faz necessário neste momento em que o engajamento virtual parece importante mas também não basta como medidor de apoio a uma causa, por mais que muitos grupos o usem como parâmetro de envolvimento e diretriz para suas ações.

As "vaquinhas" ou crowdfunding aparecem como opção para a viabilidade de projetos menores, onde as necessidades de concretização são mais palpáveis em que os gastos estariam em um nível mais próximo ao que as pessoas em geral conseguem vislumbrar. No caso do TBC, esse tipo de ação se faz um tanto temerária, mas para a ATBC ele é bastante plausível, a depender das ações a serem apresentadas à sociedade para chamar atenção à causa, além dos Seminários e leituras dramáticas realizadas até o momento e das peças ocasionalmente produzidas.

No meio desse rol de possiblidades, as empresas privadas continuam entrando como entidades algo alheias ao momento. É notório que elas não agem pela cultura nacional do mesmo modo que nos anos 1950. Nesse sentido, se em geral o poder público encampou para si - ainda que timidamente - as idéias originais do modelo da França de ação estatal na cultura, as empresas tomam para si o modelo estadunidense como o ideal, e para isso influenciam agentes públicos mais próximos para colocarem suas ideias em pauta, ou mesmo para que não haja grandes mudanças nas iniciativas vigentes.

O caso da discussão sobre a Lei Rouanet no início de 2019, com ao menos duas mudanças significativas no teto passível de captação (primeiro, para um milhão de reais, depois para dez milhões), ao mesmo tempo em que várias exceções foram assinaldas, tais como para produção de musicais e realização de programas anuais em museus e centros culturais privados - justamente os maiores captadores históricos e os que mais extrapolam o alegado teto - mostram que o poder do lobby continua sendo uma questão onde, segundo o ditado, "quem pode mais chora menos". 
Nesse sentido, fica difícil pensar que uma empresa privada de proeminência, por mais que ela estivesse preocupada com o impacto da ação social de seus negócios culturais a partir do que diz a sua cartilha de marketing cultural, fosse investir na causa do TBC se não visse nela uma possibilidade de expandir sua marca, e esse foi o estopim para o início da mobilização que culminou na associação: a ligação entre entes públicos e privados onde o lobby é contado como uma vantagem corporativa de um ente privado por cima do interesse público. E por mais que o interesse público pela reabertura do teatro possa ser coincidente com a vontade da empresa - ou do poder público que gostaria de passar adiante essa responsabilidade -, o modo com que essa opinião pública havia sido suplantada pelo anúncio de licitação colocado por Sá Leitão em 2017 dá razão para a mobilização.

Não que a associação ambicione não ter tratativa alguma com entes privados, afinal ambos estão inseridos numa lógica capitalista e dela não se escapa por vontade própria. Porém, o interesse maior da associação em defender os interesses da sociedade civil se coloca em primeiro lugar. Para isso, a campanha pela chamada de novos sócios à associação se faz cada vez mais premente para que qualquer um que se colocar perante a associação veja que ela representa interesses bem maiores que os seus. Nesse caso, enquanto os artistas, assim como o público identificado com o teatro, se sintam representados pela causa e pela condução como ela está sendo feita, assim será feito.

Os modos de trabalho coletivos estão no cerne do que se pode chamar de Teatro em todos os tempos. Nesse caso, pensar no teatro que legou a sistematização da figura de um único diretor para um grupo limitado poderia soar anacrônico. Não se pretende mesmo ficar apenas no saudosismo, mas em uma maneira de pensar que as condições que fizeram com que esse teatro acontecesse nesta cidade deveriam ser pensadas e buscadas para se atingir objetivos mais nobres. Evidentemente que, na caminhada para isso, Zampari também teve seus erros e equívocos enquanto administrador, diretor presidente e líder. Tais erros foram legados principalmente pela vontade de manter todo o possível sob seu controle. Mas é inegável que ele tinha espírito público, dentro de sua lógica empresarial. 
"Sejamos realistas. Peçamos o Impossível”. Essa frase da França de 1968, que mostra a superação de um obstáculo para ilustrar o que permanece após se fazer aparentemente um esforço tamanho por tão pouco, ecoa para se pensar no quanto os caminhos para a concretudedessa ansiada realização, a reabertura do TBC, levará ainda algum tempo. Mas é preciso insistir, levantar a "tampa da memória”. Quiçá isso acabe instigando novas lembranças e novos meios de fazer acontecer o que se deseja.

Não se pensava historicamente no poder público como parada primeira e obrigatória para provisão de recursos, para teatro ou qualquer arte. E isso não quer dizer que eram tempos "melhores", ou que foi isso que fez com que a iniciativa privada arregaçasse as mangas. Isso era resultado de um Estado ainda deficiente e altamente engessado, que não sabia sequer quais eram suas prioridades para além da manutenção da máquina do poder, ou que se satisfizesse em mitigar vontades ao invés de saciar sonhos de emancipação. O florescimento do teatro paulista com o crescimento desenfreado da cidade, além de resultado da euforia privada, também se fez por causa das pessoas que aqui estavam a consumir cultura, em meio às infindáveis obras e transformações no período dos anos 1940 a 1960.

Uma coisa que o TBC pode ter deixado e que permanece até hoje é o sentido da palavra 'independência'. Não que ele fosse um teatro independente e alheio ao seu contexto, mas os artistas que de la saíram aprenderam como se colocar em meio ao cenário feroz da concorrência, e também que ninguém ganha nada sozinho. Alguns como Cacilda Becker levaram consigo a consequência dessa consciência, morrendo em meio aos seus embates. Com esse histórico nas costas, há de ainda se buscar um meio para que a produção artística nacional, e a teatral em particular, não se vejam desamparados e sem direção quanto às possibilidades de financiamento, sob risco desnecessário de desmontar uma expressão que busca um meio de se manter ativa de maneira intermitente, sustentável e planejada sob modos próprios. 


\section{REFERÊNCIAS}

\section{REFERÊNCIAS BIBLIOGRÁFICAS}

ÁGORA TEATRO, Teatro Paulistano Séc. V: Encontros para um Entendimento no Século XXI. São Paulo: Ágora, 2006

ANGELO, Victoria Rocha de Oliveira. O retorno de um marco teatral: Proposta de revitalização arquitetônica para o TBC. São Paulo: Senac Santo Amaro, 2016

ALTHUSSER, Louis. Ideologia e Aparelhos Ideológicos do Estado. Lisboa/São Paulo: Editorial Presença/Martins Fontes, 1980

ASSUNÇÃO, Paulo de; A cidade de São Paulo no século XIX: ruas e pontes em transformação. In: Revista do Arquivo do Estado de São Paulo, n. 10, ano 1, 2006. Disponível em: <http://www.historica.arquivoestado.sp.gov.br/materias/anteriores/ edicao10/materia03/texto03.pdf> Acessado em 10 de julho de 2019

ARRUDA, Maria Arminda do Nascimento. Empreendedores Culturais imigrantes na São Paulo de 1950. In: Revista Tempo Social, v.17, n.1. São Paulo: FFLCH/USP, junho/2005, p. 135-158

Meio do Século XX, Florianópolis: EDUSC, 2001

Metrópole e Cultura: São Paulo no

AZEVEDO, Elizabeth Ribeiro. Conservatório Dramático e Musical de São Paulo: pioneiro e centenário. In: Revista do Arquivo do Estado de São Paulo, n. 16, 2013. Disponível em: <http://www.historica.arquivoestado.sp.gov.br/ materias/anteriores/edicao16/materia01/texto01.pdf>, Acessado em 10 de julho de 2019

BARROS DE ALMEIDA, Maria Inez. Panorama Visto do Rio: Companhia Tônia-Celi-Autran. Rio de Janeiro: MinC INACEN, 1987a

Cacilda Becker, Rio de Janeiro: MinC INACEN, 1987b

Panorama Visto do Rio: Companhia

BARROS, Orlando de. A guerra dos artistas: dois episódios da história brasileira durante a Segundo Guerra Mundial, E-Papers, 2010

BATISTA, Liz. Era uma vez em SP:Teatro Boa Vista. In: O Estado de S. Paulo, 10 de abril de 2015, Disponível em: $<$ http://acervo.estadao.com.br/noticias/acervo, erauma-vez-em-sp-teatro-boa-vista,10972,0.htm> Acessado em 18 de julho de 2019

BRANDÃO, Tania. Uma Empresa e Seus Segredos: Companhia Maria Della Costa. Sâo Paulo: Perspectiva, 2009

BRASIL. Constituição (1988). Constituição da República Federativa do Brasil. Brasília, DF: Senado, 1988.

CAMARGO, Angelica Ricci. XX Encontro Regional de História - UNESP Franca, 06 a 10 de setembro de 2010, Estado e Teatro: As Experiências da Comissão e do Serviço Nacional do Teatro (1936-1945), CD-Rom, 2010

; Arquivos institucionais e a história do teatro no Brasil: o caso do Serviço Nacional de Teatro; in: Revista Sala Preta., vol. 17, n.2, 2017. São Paulo: PPGAC-ECA/USP, p. 164-180 
CAMPOS, Maria da Conceição Parahyba. Abílio Pereira de Almeida: Das origens aos palcos. Tese de doutorado (Instituto Estudos da Linguagem). Unicamp, Campinas, 2009

CARDOSO, Roberto Carvalho. A utilização da cotação do dólar para eliminar efeitos da inflação. In: Revista de Administração de Empresas, Rio de Janeiro: FGV, abr./jun. 1971

CARNEIRO, Leonel Martins, A construção do espectador teatral contemporâneo, in: Revista Sala Preta, v. 17, n.1, São Paulo: USP, 2017

CARVALHO, Ricardo. Maestro: A volta por cima de J. C. Martins e outras histórias. São Paulo: Gutenberg/Autêntica, 2015

CARVALHO FRANCO, Maria Silvia de. Homens Livres na Ordem Escravocrata. Ed. Unesp, São Paulo, 1997

CAVALCANTI, Lauro. Modernistas na Repartição, Rio de Janeiro, EdUFRJ/Min-IFHAN, 2000

CHICK, Victoria. Sobre moeda, método e Keynes - Ensaios Escolhidos. Campinas: Ed. Unicamp, 1992

COLISTETE, Renato Perim. Salários, produtividade e lucros na indústria brasileira, 1945-1978. In: Revista de Economia Política, vol 29, out./nov. São Paulo: FGV, 2009

DESGRANGeS, Flavio; LEPIQUE, Maysa (org.), Teatro e Vida Pública: O Fomento e os Coletivos Teatrais de São Paulo. São Paulo: Hucitec, 2012

DORIA, Gustavo, Moderno Teatro Brasileiro, Rio de Janeiro: SNT Editora, 1975

DIONYSOS, Especial TBC, n.25. Rio de Janeiro: SNT Editora, 1980

DUARTE DOS SANTOS, Joaquim Eloy; D. Pedro II no Teatro. Palestra no Seminário "As Muitas Faces de Pedro" - 28/11/2005. Instituto Histórico de Petrópolis e Museu Imperial. Publicado em 2007. Disponível em $<$ http://www.ihp.org.br/26072015/lib_ihp/docs/jeds20051128.htm>, Acessada em 08 de julho de 2019

ESTATUTO SOCIAL ATBC, 10 de abril de 2018.

FALCÃO, Debora Arruda; DE FRANCISCO, Flávia; RAPUANO, Raquel de Sena; GONÇALEZ, Sabrina Daniele. Vera Cruz: Novos Ideais. In: Revista PJ: BR Jornalismo Brasileiro, ed.6, 2006, Disponível em:<www.eca.usp.br/pjbr/arquivos/ dossie6_d.htm> Acessado em 18 de julho de 2019

FARIA, João Roberto (org.), História do Teatro Brasileiro Vol. 1: Das Origens ao Teatro Profissional da Primeira Metade do Século XX. São Paulo: SESC, 2012

FIANI, Ronaldo. Há uma "Doença de Custos" nas Atividades Culturais?; in: Revista Carbono, Dossiê Dinheiro, n.4, 2013, Online. Disponível em: $<$ http://www.revistacarbono.com/edicoes/04/> Acessado em 18 de agosto de 2019 
FELDMAN, Sarah; VILLACA, Flavio. Planejamento e zoneamento. São Paulo: EDUSP, $3^{\mathrm{a}}$ ed. 2005

FERREIRA, Rosê, Projeto de Lei 3827, Rio de Janeiro: Câmara dos Deputados, 1958

FONSECA, Marcelo Marcus; Teatro do Incêndio: Da Terra ao Território; São Paulo: Ed. Córrego, 2018

FRIQUES, Manoel Silvestre; Edital é pouco, meu prêmio primeiro: uma análise material do "mercado" teatral brasileiro; in: Revista Sala Preta. São Paulo, vol. 16, n.1, 2016, PPGAC-ECA/USP, p. 179-213

GARCIA, Miliandre. Da resistência à desobediência: Augusto Boal e a I Feira Paulista de Opinião (1968). In: Revista Varia Historia. 2016, vol.32, n.59, pp.357-398

A censura de costumes no Brasil: Da institucionalização da censura teatral no século XIX à extinção da censura na Constituição de 1988. Rio de Janeiro, Fundação Biblioteca Nacional, 2009

GARCIA, Silvana. Teatro em Ascensão, in: Revista E Sesc, n.183, São Paulo: Edições SESC, 2012. Disponível em:<https://www.sescsp.org.br/online/artigo/6341_ TEATRO+EM+ASCENSAO $>$ Acessado em 18 de agosto de 2019

GÓES, Marta. Alfredo Mesquita - Um grã-fino na contramão. CBA/Votorantim, 2007

GOMES, Carlos Antonio Moreira; MELLO, Marisabel Lessi de (orgs.), Fomento ao Teatro: 12 anos; São Paulo, Prefeitura de São Paulo - Secretaria Municipal de Cultura, 2014

GONÇALVES, Maria Clara; LEVIN, Orna Messer; Furtado Coelho e sua atuação no Teatro Ginásio Dramático do Rio de Janeiro. In: Revista Convergência Lusíada, n. 32, Rio de Janeiro, julho - dezembro de 2014

GUINSBURG, Jacob; FARIA, João Roberto; DE LIMA, Mariângela Alves; Dicionário do Teatro Brasileiro - Temas, Formas e Conceitos. São Paulo: Edições SESC, $2^{\mathrm{a}}$ ed., 2006

GUZIK, Alberto. TBC - Crônica de um Sonho. São Paulo: Perspectiva, 1986

HIPÓLIDE, Eduardo Gramani, O teatro anarquista como prática social do movimento libertário: São Paulo e Rio de Janeiro - de 1901 a 1922, Dissertação de Mestrado (História). São Paulo: PUC, 2012

INSTITUTO CULTURAL CIDADE VIVA, Perfil de Empresas Patrocinadoras: 50 Dicas de Marketing Cultural. Rio de Janeiro: Record/UFF, 2003

LAET, Maria Aparecida. Arquivo Miroel Silveira: uma leitura dos processos da censura prévia ao teatro sob o prisma do gerenciamento de informações. Dissertação de Mestrado (Teoria e Pesquisa em Comunicação). São Paulo: ECA/USP, 2007

LEI ROUANET - Conheça esse sistema de incentivo à cultura; $1^{\mathrm{a}} \mathrm{ed}$, in: Forum Brasileiro pelos Direitos Culturais. São Paulo: Conteúdo Comunicação, 2016.

LEIVA, João. Teatro em SP, São Paulo: J.Leiva Cultura e Esporte, 2019. 
LEMOS, Valéria Pinto (org.). Os Exames Censórios do Conservatório Dramático Brasileiro: Inventário Analítico, Rio de Janeiro: Fundação Biblioteca Nacional, 2014

LOUREIRO, Edison. O Começo e o Fim do Teatro São José. In: São Paulo Passado, 8 de agosto de 2015. Disponível em: <https://saopaulopassado. wordpress.com/2015/08/08/o-comeco-e-o-fim-do-teatro-sao-jose/> Acessado em 12 de julho de 2019

LÍCIA, Nydia. Eu vivi o TBC, São Paulo: Arquivo Oficial do Estado, 2007

MACHADO,Álvaro. Teatro Popular do SESI: 40 anos. São Paulo: SESI, 2004

MAFFEI, Evangelina. "1965 - Arena Canta Bahia”, 27 de agosto de 2011, in: Caetano En Detalle, Argentina, Buenos Aires. Disponível em: $<$ caetanoendetalle.blogspot.com/2011/08/1965-arena-canta-bahia.html?m=0 > Acessado em 02 de agosto de 2019

MAGALDI, Sabato. Panorama do Teatro Brasileiro, São Paulo: Global, 1997

Paulo. São Paulo: SENAC, 2001

; VARGAS, Maria Thereza. Cem Anos de Teatro em São

MANZONI, Francis Marcio Alves. Passagens da Biblioteca Central ao Centro Cultural São Paulo (1975-1985). Tese de doutorado (História) - São Paulo: PUC, 2015

MARTINS ARANTES, Luiz Humberto. Teatro da Memória: História e Ficção na Dramaturgia de Jorge Andrade. São Paulo: Annablume/FAPESP, 2001

MARTOS, Luis Antonio Palma; QUINTERO, Luis Fernando Aguado; Debe el Estado financiar las artes y la cultura?: Revisión de literatura; in: Revista Economia e Sociedade. Campinas: Unicamp, v.20, n. 1(41), abr./2011, p.196. Original em espanhol

MATE, Alexandre. Teatro SESC Anchieta: Um Ícone Paulistano, São Paulo: Edições SESC, 2017

A Produção Teatral Paulistana dos Anos 1980 R(a)biscando com Faca o Chão da História: Tempo de Contar os (Pré)juízos em Percurso de Andança. Tese de Doutorado (História). São Paulo: USP, 2008

MATTOS, David José Lessa. O Espetáculo da Cultura Paulista: Teatro e TV em São Paulo (1940-1950). São Paulo: Codex, 2002

MICELI, Sergio (org.). Estado e Cultura no Brasil. São Paulo: IDESP, 1984 Intelectuais brasileiros. In: O Que Ler na Ciência Social Brasileira (1970-1995). Volume II-Sociologia. São Paulo: ANPOCS/Editora Sumaré/ CAPES, 2012, p. 109-145. Disponível em <http://anpocs.org/index.php/o-que-ler-19701995/volume-ii-sociologia/641-intelectuais-brasileiros/file> Acessado em 21 de julho de 2019

MICHALKSI, Yan; TROTTA, Rosyanne. Teatro e Estado. São Paulo: Hucitec, 1992

MILARE, Sebastião, Desafios dos Novos Tempos, in: Revista àParte XXI, n.3, São Paulo: Edusp, $2^{\circ}$ sem./2010. p. 11-24

MOTIN/PROVOKERS. Cartografia dos Teatros de São Paulo - Estudo Quantitativo; São Paulo: Governo do Estado de S. Paulo, Junho/2015 
MOUTINHO, Carina. Breve análise das politicas públicas culturais para o Teatro em Portugal e no Brasil: uma visão da atuação nas cidades do Porto e São Paulo; in: Revista do Centro de Pesquisa e Formação. n. 3, São Paulo: Ed. Sesc, Novembro/2016

MUNDANA COMPANHIA, Imersão Selva. São Paulo: Prefeitura/PRCEUUSP, 2016

MUNHOZ, Dercio Garcia. Inflação brasileira: Os Ensinamentos desde a Crise de 30, in: Revista de Economia Contemporânea, Rio de Janeiro: UFRJ, 1997

PATRIOTA, Rosangela. História e Historiografia do Teatro Brasileiro da Década de 1970: Temas e Interpretações. in: Revista Baleia na Rede, Marília: Unesp, 2012. Disponível em: <http://www.bjis.unesp.br/revistas/index.php/baleianarede/article /viewFile/2836/2214> Acessado em 15 de agosto de 2019

POMPEU DE TOLEDO, Roberto. A cidade em vertigem - Uma história de São Paulo de 1900 a 1954, São Paulo, Cia. das Letras, 2015

PIRES JÚNIOR, Sidney Oliveira. XXII Encontro Estadual de História ANPUHSP - Santos. Mário de Andrade e o contexto de criação do SPHAN. CD-Rom, 2014

PONTES, Heloísa. Intérpretes da Metrópole. São Paulo: EDUSP, 2011

PRATES, Daniela Magalhães; CINTRA, Marcos Antônio Macedo. Keynes e a hierarquia de moedas: possíveis lições para o Brasil, in: Texto para Discussão, n.137. Campinas: IE/Unicamp, out./2007

PREFEITURA DO MUNICÍPIO DE SÃO PAULO. São Paulo Antigo: Plantas da Cidade. São Paulo: Comissão do IV Centenário, 1954

QUADROS, Jânio. Mensagem apresentada pelo Governador à Assembléia Legislativa em 14 de março de 1958, in: BIBLIOTECA NACIONAL. Hemeroteca Digital. Disponível em: <www.memoria.bn.br> Acessado em 12 de agosto de 2019

RAULINO, Berenice. Ruggero Jacobbi. São Paulo: Perspectiva, 2002

SECRETARIA DE ESTADO DA CULTURA, Cenografia e Indumentária no TBC: 16 anos de História (1948-1964). São Paulo, 1980, p.36

SERROUSSI, Benjamin; Dependências Táticas; in: Revista Select. São Paulo, n.39, junho-julho-agosto/2018, p. 40/1

SCHMIDT, Bernardo. "A Semente", in: blog O Patativa. 04 de fevereiro de 2010. Disponível em <http://bernardoschmidt.blogspot.com/2010/02/semente-deguarnieri.html?m=1> Acessado em 15 de agosto de 2019

SILVA, Charles Roberto. Teatro Para os Trópicos: O Governo Imperial Brasileiro e a Questão Teatral (1822-1889), FFLCH/USP, São Paulo, 2017

SILVA, Armando Sergio da. Uma Oficina de Atores - A Escola de Arte Dramática de Alfredo Mesquita. São Paulo: EDUSP, 1989

Paulo: Ed. Perspectiva, 1981

Teatro Oficina: Do Teatro ao Te-Ato. São

SILVEIRA, Miroel. A Contribuição Italiana ao Teatro Brasileiro - 18651964. Ed. Kiron/MEC, Brasília, 1976a . A Outra Crítica, São Paulo: Ed. Símbolo, 1976b 
SIMÔES, Giuliana Martins. Veto ao Modernismo no Teatro Brasileiro, São Paulo: EdUSP, 2009

TURINO, Celio. Pontos de Cultura, São Paulo: Ed. Anita Garibaldi, 2017

URDI ARQUITETURA. TBC - Teatro Brasilieiro de Comédia. Disponível em: $\quad<$ http://www.urdi.com.br/projetos-arquitetura-teatros-tbc---teatro-brasileiro-decomedia $>$ Acessado em 17 de agosto de 2019

URFALINO, Phillipe. A invenção da política cultural, São Paulo: Edições SESC, 2015

VARGAS, Maria Thereza; ALVES DE LIMA, Mariângela. Teatro Operário na Cidade de São Paulo, Prefeitura de São Paulo, 1980

VERAS, Flavia Ribeiro. XXVI Simpósio Nacional de História - ANPUH, São Paulo, jul. 2011. Artistas como Trabalhadores: a sua história através dos arquivos da polícia, 2011. Disponível em $<$ https://www.academia.edu/25179912/Os_artistas como_trabalhadores_a_sua_hist $\% \mathrm{C} 3 \% \mathrm{~B} 3$ ria_atrav $\% \mathrm{C} 3 \% \mathrm{~A} 9 \mathrm{~s}$ sdos_arquivos_da_pol $\% \mathrm{C}$ $3 \%$ ADcia $>$ Acessado em 28 de julho de 2019

VELOSO, Verônica Gonçalves. Grupo ou Coletivo - Uma Questão de Tempo. In: Anais ABRACE, v.9, n.1. Campinas: Unicamp, 2009

VELOSO-PAMPOLHA, Augusto. XXX Congresso Brasileiro de Ciências da Comunicação Intercom, 29 de agosto a 02 de setembro de 2007. Teatro Musicado e censura em São Paulo (1920-1950), Santos: Unisanta, 2007

VENEZIANO, Neyde; De Pernas Pro ar: Teatro de Revista em São Paulo; Coleção Aplauso. São Paulo, Imprensa Oficial, 2006. 